UNIVERSIDADE DE SÃO PAULO - USP

FACULDADE DE FILOSOFIA, LETRAS E CIÊNCIAS HUMANAS

DEPARTAMENTO DE CIÊNCIA POLÍTICA

PROGRAMA DE PÓS-GRADUAÇÃO EM CIÊNCIA POLÍTICA

\title{
FORMAÇÃO DE AGENDAS \\ GOVERNAMENTAIS LOCAIS: O CASO DOS \\ CONSÓRCIOS INTERMUNICIPAIS
}

\author{
Aluno: EDUARDO DE LIMA CALDAS \\ Orientador: Prof. Dr. EDUARDO CESAR MARQUES
}

São Paulo

2007 


\title{
UNIVERSIDADE DE SÃO PAULO - USP \\ FACULDADE DE FILOSOFIA, LETRAS E CIÊNCIAS HUMANAS \\ DEPARTAMENTO DE CIÊNCIA POLÍTICA \\ PROGRAMA DE PÓS-GRADUAÇÃO EM CIÊNCIA POLÍTICA
}

\section{FORMAÇÃO DE AGENDAS \\ GOVERNAMENTAIS LOCAIS: O CASO DOS CONSÓRCIOS INTERMUNICIPAIS}

\author{
Tese apresentada à Banca \\ Examinadora da Universidade de São \\ Paulo como exigência parcial para \\ obtenção do título de Doutor em \\ Ciência Política, sob a orientação do \\ Professor Doutor Eduardo César \\ Marques.
}

\author{
Aluno: EDUARDO DE LIMA CALDAS \\ Orientador: Prof. Dr. EDUARDO CESAR MARQUES
}

São Paulo 
Caldas, Eduardo de Lima.

Formação de Agendas Governamentais Locais: o caso dos Consórcios Intermunicipais / Eduardo de Lima Caldas - 2007

Orientador: Eduardo César Marques

Tese (doutorado) - Faculdade de Filosofia, Letras e Ciências Humanas da Universidade de São Paulo (FFLCH-USP)

1. Políticas Públicas - Brasil - Processos Decisórios. 2. Processos Políticos - Brasil - Governos Locais. 3. Governos Locais - Inovação Arranjos Governamentais. I. Marques, Eduardo César. II. Tese (doutorado) - Faculdade de Filosofia, Letras e Ciências Humanas da Universidade de São Paulo (FFLCH-USP). III. Título. 
Aos meus pais, Paulo e Clarice.

Ao meu irmão, Fabiano.

Á minha esposa, Patrícia e ao meu filho, Antônio 


\section{Agradecimentos}

Agradeço ao meu orientador, principalmente pela paciência, e a cada membro da Banca de Defesa que gentilmente aceitou o convite.

Agradeço à Professora Doutora Marta Arretche e ao Professor Doutor Fernando Limongi por terem participado do processo de qualificação deste trabalho e pelas observações e sugestões que fizeram. Agradeço também aos demais professores do Departamento de Ciência Política, com os quais tive aulas. Aproveito a oportunidade para agradecer aos Professores Doutores Fernando Limongi e Simone Diniz pelo período em que fui "monitor" na Disciplina por eles lecionada (Política IV).

Agradeço aos funcionários do Departamento de Pós-Graduação pela dedicação incansável e pela paciência. Agradeço especialmente à Rai que em várias ocasiões não permitiu que eu perdesse prazos e que sempre me deu dicas importantíssimas sobre os mais diversos procedimentos internos de funcionamento do Departamento.

Agradeço aos amigos que, de alguma forma, direta ou indiretamente, contribuíram para a execução deste trabalho. Neste conjunto estão os amigos que trago do CEPAM, do Instituto Polis, da Faculdade de Economia (FEA-USP), do Departamento de Ciência Política (FFLCH-USP), da Fundação Getúlio Vargas, e da Secretaria Estadual da Justiça e da Defesa da Cidadania.

Agradeço ao Hélio por ter lido e comentado uma versão da Tese em momento que considerei bastante crítico.

Um agradecimento bastante especial ao Vaz (José Carlos Vaz) pela convivência quase diária ao longo dos vários anos em que trabalhei no Polis e pela paciência e generosidade com que leu várias versões desta Tese e de tantos outros trabalhos, pelas observações atentas e pelo incentivo em momentos difíceis.

Agradeço ao Rafa (Rafael D'Almeida Martins) com quem tenho discutido diversos temas e que ao longo do processo de execução deste trabalho me ajudou lendo, relendo, comentando, sugerindo leituras, e auxiliando inclusive na pesquisa bibliográfica.

Agradeço à Renata que sempre inventa passeios, festas, jantares, transmite um bom humor danado e ainda revisou meu parco inglês.

Agradeço aos amigos de Suzano e aos funcionários da Musicultural, comércio de Livros e Discos, pelos auxílios operacionais, pelas conversas e pela prontidão.

Agradeço aos meus pais pela infindável paciência, tolerância, pela generosidade, pelas discussões, pelas diversas formas de incentivo e de apoio que nunca me deixaram faltar. Ao meu irmão, Fabiano.

Um agradecimento muito especial à minha esposa Patrícia e ao meu filho Antônio por toda paciência, pelas mais diversas formas de ajuda ao longo dessa travessia (e principalmente nestes últimos meses).

Outro agradecimento à Pati que leu e comentou várias versões da Tese, além de ter colaborado de diversas formas principalmente nestes últimos dias (quase insuportáveis).

Agradeço a Deus.

Agradeço, finalmente, ao CNPq pelo apoio financeiro, de novembro de 2004 a fevereiro de 2007. 
"Combati o bom combate".

(São Paulo, Apóstolo)

"Deus é paciência. O contrário é o diabo".

(João Guimarães Rosa) 


\section{RESUMO}

O objetivo principal desta Tese é analisar e compreender as particularidades dos processos de criação de Consórcios Intermunicipais em três Estados brasileiros. Os Consórcios analisados são o Consórcio Intermunicipal de Produção e Abastecimento de São Luís (MA); o Consórcio Intermunicipal das Bacias do Alto Tamanduateí e Billings (Grande ABC-SP); os Consórcios Intermunicipais de Saúde de Minas Gerais.

A questão central que orientou esta pesquisa foi a seguinte: como surgem os Consórcios Intermunicipais no Brasil, ao longo dos anos 90 ?

Para responder esta questão, o trabalho foi estruturado a partir de três recortes: teórico, temático e empírico.

Por meio do recorte teórico foi possível apresentar um arcabouço respaldado principalmente no que se convencionou chamar de formação de agendas de governo.

Por meio do recorte temático foi possível localizar este estudo na órbita das questões relativas aos municípios brasileiros, bem como situar o debate sobre a cooperação intermunicipal ao longo do tempo.

Por meio do recorte empírico realizou-se a pesquisa de campo orientada pela teoria previamente analisada.

A hipótese central desta Tese é a de que a criação dos Consórcios Intermunicipais depende de dinâmicas locais nas quais dois fatores são fundamentais: a presença de um empreendedor de políticas públicas e a identificação de uma janela de oportunidades.

Em outras palavras: os Consórcios Intermunicipais resultam de formas peculiares de como se articulam os interesses locais em torno de determinado "setor" de políticas públicas.

Palavras-Chave: processo decisório, formação de agenda, políticas públicas, neoinstitucionalismo, consórcios intermunicipais. 


\section{ABSTRACT}

The main goal of this thesis is to analyse and comprehend the circumstances of the Intermunicipalities Consortia creation processes in three different Brazilian States. The Consortia chosen for analysis are: São Luis Intermunicipal Consortium of Production and Supply (MA), Tamanduateí and Billings Basins Intermunicipal Consortium (Great ABC - SP) and Minas Gerais Intermunicipal Consortia for Health.

The main question that guided this research was the following: how do intermunicipal consortia appeared in Brazil along the 1990s?

To answer the question, the thesis was structured in theoretical, thematic and empirical schemes.

The groundwork mainly based on what was conveniently called the Creation of Government Agenda was possible through the theoretical scheme.

Through the thematic scheme, it was possible to place this study in the scope of the questions related to the Brazilian municipalities, as well as establishing the debate about intermunicipal cooperation through time.

Through the empirical scheme, a field research was realised based on the theory previously analysed.

The main assumption of this thesis is that the creation of intermunicipal consortia depends on the local dynamics in which two factors are essential: the presence of an entrepreneur of public policies and the identification of a window of opportunities.

In other words, intermunicipal consortia are a result of peculiar forms of how local interests become linked around a specific "sector" of public policies.

Key words: decision process, agenda creation, public policies, neoinstitutionalism, intermunicipal consortia. 


\section{LISTA DE ILUSTRAÇÕES}

Quadros, Gráficos e Tabelas

\begin{tabular}{|c|c|}
\hline Figura 1: De Situação a Problema & 30 \\
\hline Figura 2: Alternativas Públicas para Resolução de Problemas & 32 \\
\hline Figura 3: A Tomada de Decisões & 33 \\
\hline $\begin{array}{l}\text { Quadro 1: Consórcios Intermunicipais de Alimentação (CIA) no } \\
\text { Estado de São Paulo - 1983-1986 }\end{array}$ & 72 \\
\hline $\begin{array}{l}\text { Tabela 1: Municípios Consorciados por tipo de Consórcio, } \\
\text { segundo Tamanho da População }\end{array}$ & 73 \\
\hline $\begin{array}{l}\text { Tabela 2: Municípios Consorciados por tipo de Consórcio, } \\
\text { segundo Macrorregião Geográfica }\end{array}$ & 74 \\
\hline Quadro 2: Consórcios Intermunicipais por Categorias Analíticas & 75 \\
\hline $\begin{array}{l}\text { Quadro 3: Municípios Participantes do CINPRA e os Partidos } \\
\text { Políticos de seus respectivos Prefeitos }\end{array}$ & 99 \\
\hline Figura 4: Localização da Região do Grande ABC & 102 \\
\hline $\begin{array}{l}\text { Tabela 3: Número de Consórcios Intermunicipais de Saúde } \\
\text { segundo ano de Implantação. Estado de Minas Gerais. } 2000\end{array}$ & 139 \\
\hline
\end{tabular}




\section{SUMÁRIO}

Introdução.

\section{Capítulo 1:}

Políticas Públicas e Formação de Agendas de Governos Municipais......10

Introdução 10

Política e Políticas Públicas..........................................................12

Instituições e Atores Políticos..........................................................13

O Ciclo Dinâmico das Políticas Públicas............................................22

Formação da Agenda de Governo: primeira fase do Ciclo?..................26

A Janela de Oportunidade e o Empreendedor Político.....................................33

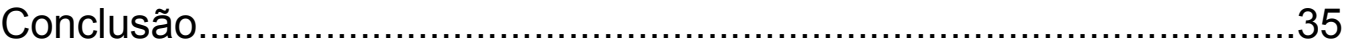

\section{Capítulo 2:}

Uma visão Panorâmica dos Consórcios Intermunicipais no Brasil............37

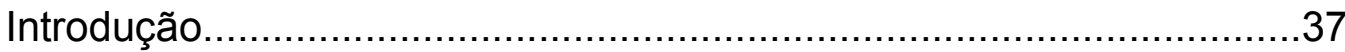

Uma Definição de Consórcios Intermunicipais..................................39

A Atualidade temática dos Consórcios Intermunicipais.......................42

Considerações sobre as Bases de Dados utilizadas...........................46

Antecedentes no ESP: os Consórcios anteriores aos anos $90 \ldots \ldots \ldots \ldots . . . .51$

Os Consórcios no Brasil no Período Pós-Constituinte............................55

Os Consórcios Intermunicipais teriam entrado na Agenda Nacional?...65

Conclusão .70 


\section{Capítulo 3:}

O Caso do Consórcio Intermunicipal de Abastecimento e Produção - MA...........78

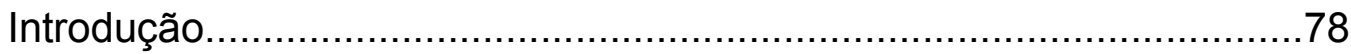

Caracterização sociopolítica de São Luís (MA) ................................78

Histórico e Caracterização do CINPRA ..........................................84

Consolidação do CINPRA........................................................93

Conclusão............................................................................ 97

\section{Capítulo 4:}

O Aparato Institucional para a Cooperação Intermunicipal no ABC Paulista.....100

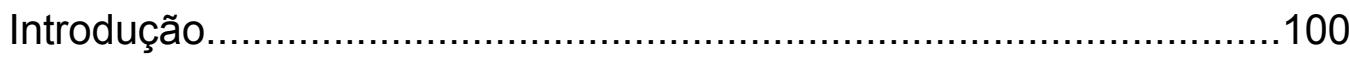

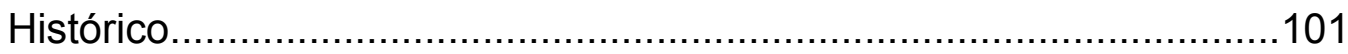

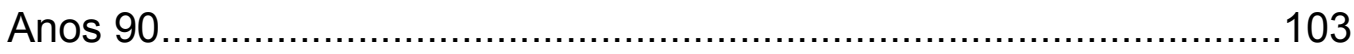

Instâncias Regionais do Grande ABC...........................................107

Consórcio Intermunicipal das Bacias do Alto Tamanduateí e Billings.............108

Fórum da Cidadania do Grande ABC........................................................111

Câmara Regional do Grande ABC e Agência de Desenvolvimento..................113

Conclusão...............................................................................

\section{Capítulo 5:}

Os Consórcios Intermunicipais de Saúde de Minas Gerais......................123

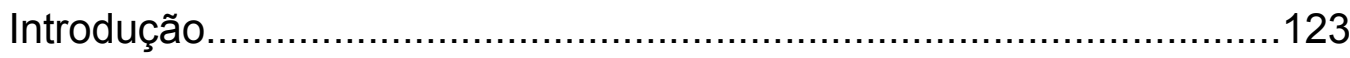

Os Consórcios de Saúde em Minas Gerais.......................................125

O CIS do Alto São Francisco (CISAF) ...........................................125

O CIS dos Municípios da Microrregião do Alto Rio Grande (CISMARG)........134

Os CIS como Política Pública Estadual..........................................137

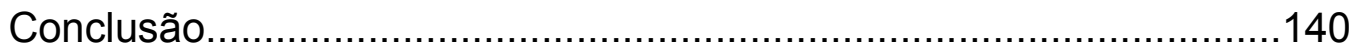


Conclusão - Análise Comparada dos Casos............................................143

As Categorias Analíticas................................................................143

O que aprendemos com o Recorte Temático?...................................145

Análise Comparada: São Luís, Santo André e Minas Gerais................147

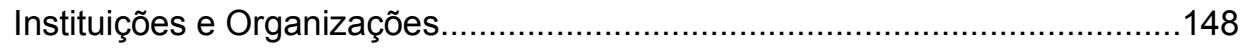

A Estrutura de Estímulos Institucionais........................................................152

O Processo de Convencimento..................................................................153

A Formulação do Problema e a Geração de Alternativas.................................154

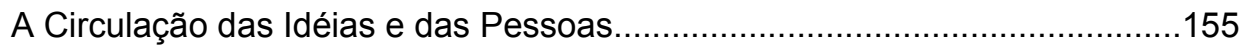

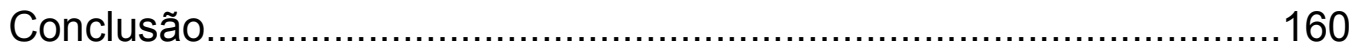

BIBLIOGRAFIA

ANEXO 01:

Nota Metodológica: a opção pela pesquisa qualitativa.............................182

ANEXO 02:

Instrumento de Coleta de Informação para a Pesquisa de Campo:

roteiro das entrevistas......................................................................189

ANEXO 03:

Relação de Entrevistas Realizadas.............................................................193

ANEXO 4:

Anteprojeto de Lei que autoriza

o Poder Executivo a Participar do

Consórcio Intermunicipal de Produção e Abastecimento.........................197

ANEXO 5:

Mensagem enviada ao

Presidente da Câmara Municipal

solicitando autorização para participar do CINPRA 
ANEXO 6:

Estatuto do Consórcio Intermunicipal de

Produção e Abastecimento - São Luís.

ANEXO 7:

Estrutura Organizacional do CINPRA

(Semelhante a vários outros Consórcios Intermunicipais).

ANEXO 08:

Guia para Criação de Consórcios Intermunicipais de

Produção e Abastecimento. 


\section{Introdução}

Como surgem os Consórcios Intermunicipais no Brasil, ao longo dos anos 90 ? Esta é a questão central que este trabalho buscará responder. Para responda-la, este trabalho foi organizado a partir de três recortes: teórico; temático (que tratará do tema consórcios de forma mais geral e mais abstrata); e empírico (que tratará de casos específicos de formação de consórcios à luz do arcabouço teórico analisado previamente). Cada um desses recortes tem a sua especificidade. Apesar disso, complementam-se mutuamente, como se cada um desses recortes fosse uma espécie de lugar por meio do qual se observa e se analisa o objeto deste trabalho: os consórcios intermunicipais.

O recorte teórico busca analisar o tema consórcio por meio de um corpo de conhecimentos acumulado pela ciência política. Nos poucos trabalhos que abordam os consórcios por meio de um conjunto ou subconjunto de conhecimentos acumulados pela ciência política, nenhum o fez por meio do que se convencionou chamar formação de agendas governamentais.

Os consórcios intermunicipais foram analisados até o presente momento ora pelo enfoque da ação racional dos atores (TEIXEIRA, MAC DOWELL e BUGARIN, 2002a, TEIXEIRA, MAC DOWELL e BUGARIN, 2002b), ora pelo enfoque do capital social (JACOBI, 2006).

Para os adeptos da teoria da escolha racional, os consórcios intermunicipais resultam de uma série de estímulos exógenos ao território no qual está sendo criado. O estímulo é vertical, uma vez que advém tanto da União quanto do Estado. O mecanismo explicativo para os adeptos da teoria da escolha racional é a ação estratégica do ator racional, que busca otimizar seus ganhos, dado um conjunto de possibilidades.

Os consórcios, compreendidos como organizações cooperativas de entes da mesma instância de governo, possibilitam a articulação de políticas públicas de "setores" de política pública como saúde, transporte ou infraestrutura, por exemplo, em determinado território, conferindo, teoricamente, maior racionalidade às políticas públicas em termos de menor fragmentação da ação e melhor utilização do recurso público. Assim, produção de leis que, por exemplo, aumentem o volume de recursos per capita para municípios que 
participem de consórcios intermunicipais específicos em torno de determinado "setor" constitui-se em mecanismo institucional que, ao induzir o comportamento cooperativo dos municípios, aumentam a racionalidade da política setorial no território.

Esta, aliás, é a explicação recorrente para o grande número de municípios que se consorciam em torno do "setor" saúde.

A análise advinda da teoria do capital social, por sua vez, lança mão da hipótese de que os consórcios intermunicipais resultam do interesse local independentemente dos estímulos externos. Neste caso, a constituição dos consórcios intermunicipais está diretamente relacionada à capacidade prévia dos municípios, seus agentes políticos e os atores sociais com raízes na localidade, estabelecerem laços e relações de confiança (verticais e horizontais). Em outras palavras, os consórcios resultam do interesse de atores em se organizarem de forma cooperativa, mas pressupõe relações de confiança estabelecidas anteriormente ${ }^{1}$.

\footnotetext{
1 Jacobi (2006) lança mão de elementos explicativos privilegiados pelos teóricos do capital social para explicar a constituição do Consórcio do Quiriri (SC). Argumentos, aliás, pertinentes para um estudo realizado no Estado de Santa Catarina, que tem uma efetiva tradição em organização territorial. Estes argumentos, evidentemente, auxiliariam na explicação do surgimento de consórcios tais como o do Grande ABC (SP), do Ribeirão Lajeado (SP) e de Três Passos (RS) ou do Quiriri (SC). Os argumentos dos teóricos do capital social não serão usados de forma sistemática ao longo deste trabalho, optei pelo uso mais sistemático de outras abordagens, dentre as quais, a teoria da formação de agenda.

De acordo com teóricos do capital social como Putnam, "confiança é um produto de longo prazo de padrões históricos de associativismo, compromisso cívico e interações extrafamiliares". Putnam (1996) e Locke (2003) valorizam o papel das organizações como mecanismos indutores de comportamentos, dados os sistemas de valores sociais e a cultura regional (daí a possibilidade de interface com o neo-institucionalismo sociológico). A tradição cívica e a participação, discutidas por Putnam (1996), aumentam a eficiência e a eficácia das organizações no sentido de induzirem comportamentos sociais. Locke (2003) preocupado em saber "como a confiança pode ser construída por meio de um processo seqüencial que combina interesses privados e políticas públicas", valoriza, em seu argumento, o papel das instituições e principalmente das organizações. A tese de Locke (2003) é a de que, empiricamente, mesmo em lugares onde não há uma tradição associativa pode-se construir relações de confiança extrafamiliares. Deriva deste raciocínio que as instituições, em função de aspectos culturais, moldam a ação dos indivíduos; e não como propugnam os adeptos da teoria da escolha racional, em razão da lógica e estratégica da ação dos atores.

Estudos relativos à formação do Consórcio Quiriri, em Santa Catarina (Jacobi e Teixeira, 2000; Jacobi, 2006), enfatizaram a tradição associativista de Santa Catarina (aspecto cultural) e a identidade local criada em torno da Bacia do Alto Rio Negro. Reunir atores sociais e políticos em torno de interesses comuns não é incomum no Estado de Santa Catarina. Desde meados dos anos 70, prefeitos reúnem-se em Associações de Municípios, ora para resolverem problemas relacionados com as redes de transmissão de energia elétrica, ora para construírem ou reformarem estradas. Esta capacidade de resolução de problemas comuns por parte dos municípios constrói, ao longo do tempo, relações de confiança entre os referidos atores e fortalece identidades nacionais.

Então, identificado o problema comum e os interesses que poderiam juntar os atores políticos em torno da resolução do problema identificado, a construção da confiança já estaria dada pela
} 
No caso da teoria do capital social, mais que ação estratégica do indivíduo, o mecanismo explicativo é o que BOURDIEU (1980:2) chamou de "ação das relações".

Dada a complexidade temática, pode-se ancorar a análise dos consórcios intermunicipais em elementos analíticos presentes tanto na teoria da escolha racional quanto na teoria do capital social, reconhecendo-se de antemão que:

1 - se é verdade que são os atores individuais (como admite a teoria da ação racional) que concretamente fazem política; também é verdade que estes mesmos atores individuais não o fazem tão-somente condicionados por mecanismos exógenos que promovem "punições" e "premiações" (constrangimentos legais, sociais e políticos), mas também movidos por crenças e idéias.

2 - se é verdade que o "estoque" de relações sociais de um determinado território é imprescindível para consolidar determinada ação que pressupõe confiança entre os atores; também é verdade que, em determinados casos, o desenho institucional, ao possibilitar o adensamento das relações sociais entre atores organizados em torno de um tema que Ihes interessa, acaba por fortalecer o grau de confiança entre os referidos atores (Locke, 2003:258).

No entanto, ainda considerando a complexidade do tema, a análise tornar-se-á mais substanciosa se ancorar-se também e principalmente no que a ciência política tem denominado formação de agendas governamentais.

A teoria da formação de agendas governamentais está localizada nas ciências sociais, no que se pode chamar fronteira entre duas tradições da ciência política: uma tradição com raízes mais européia e outra tradição mais americana.

$\mathrm{Na}$ Europa o campo de conhecimento da política pública surge e se fortalece como desdobramento das teorias que procuram explicar o papel do Estado e do Governo - este último, produtor, por excelência de políticas públicas (Souza, 2006: 22).

tradição associativista da região e pela própria identidade regional.

Segundo Jacobi (2006), sempre houve a cultura da associação e da cooperação entre os municípios, interpretada, muitas vezes, como herança da colonização alemã. 
Nos Estados Unidos, por sua vez, o campo de conhecimento da política pública está mais diretamente preocupado com as ações do governo, ou seja, em saber como são implementadas determinadas ações de governo, e como são resolvidos, por meio da ação de governo, problemas socialmente relevantes.

Assim, a política pública passou a ser vista na tradição americana, ora como um campo de conhecimento que estava voltado para a especialização "setorial", ou seja, especialização em torno de políticas públicas governamentais tais como educação, saúde, transporte, saneamento básico, dentre outros; ora como campo de conhecimento "técnico" e restrito que analisava a política pública como um ciclo ou uma seqüência de procedimentos iniciado na elaboração de um projeto, passando por sua implementação e finalizando na sua avaliação.

A teoria da formação de agenda, na medida em que analisa o processo "pré-decisório" posiciona-se de forma estratégica entre as duas tradições da ciência política: a européia e a americana.

Ao analisar o processo "pré-decisório", a teoria da formação de agenda obriga-se a desdobrar os mecanismos causais que introduzem determinado tema na agenda de governo, e portanto, obriga-se a entender as relações políticas dos atores políticos envolvidos com a formulação de determinada política pública e a influência exercida por estes atores sobre os contornos da política pública a ser implementada. Deste modo, ações de governo e "contingências" políticas são variáveis definidoras de determinada política.

A teoria da formação de agenda ${ }^{2}$ não abre mão de encarar a política pública como um ciclo. No entanto, dadas as contingências políticas, os ciclos de políticas públicas na perspectiva da teoria da formação de agenda não é linear. Pelo contrário, é sinuoso e complexo.

\footnotetext{
${ }^{2}$ A teoria sobre formação de agenda foi construída por um conjunto de estudiosos, entre os quais Cobb e Elder (1995), Cobb, Ross e Ross (1976), Downs (1972), Elder e Cobb (1984), Baumgartner e Jones (1993), March, Olsen e Cohen (1972) e Kingdon (2003). Este trabalho está fortemente ancorado na tese de Kingdon (2003), que por sua vez utilizou amplamente o trabalho de Olsen e Cohen (1972).
} 
Assim, a teoria da formação de agenda preocupa-se em saber como o governo toma decisão sobre determinada política pública num ambiente político plural e sob a influência e a pressão de grupos diversos.

A questão geral que os teóricos dedicados à formação de agendas governamentais buscam responder é a seguinte: como determinado tema torna-se relevante para o governo?

Para o caso específico dos consórcios intermunicipais, a pergunta é a seguinte: como a despeito do tema ter se tornado de grande relevância para a agenda do governo nacional (se é que isso ocorreu), em determinados territórios, tornou-se relevante?

Esta questão desdobra-se em outras tantas: Como foram constituídos esses consórcios? Quais os atores sociais envolvidos na constituição dos referidos consórcios? Quais os setores e os interesses envolvidos na constituição dos referidos consórcios? Havia, no território, uma rede de relações sociais previamente constituídas entre os atores envolvidos? A Constituição desses consórcios intermunicipais contou com a presença marcante de algum agente que articulou os diversos interesses em torno de um tema?

Deste modo, ao introduzir estas questões, o trabalho, ora apresentado, buscará, do ponto de vista teórico, compreender a inserção dos consórcios na agenda de determinados governos locais.

Parte-se do pressuposto de que a institucionalização dos consórcios na forma da lei no âmbito federal não foi condição necessária para que os mesmos participassem das agendas dos governos locais, até porque em muitas localidades, como fôra visto por meio do recorte temático, os consórcios intermunicipais entraram nas respectivas agendas locais antes da criação de leis federais. Aliás, nesta medida, muito provavelmente, o surgimento de consórcios difusos no território e em torno de setores diferentes podem ter criado volume de experiência suficiente para respaldar um projeto de lei federal, fortalecendo o interesse de atores nacionais em torno do tema. 
Mais especificamente, busca-se compreender a inserção dos consórcios na agenda dos governos locais, no período imediatamente anterior à criação da lei federal sobre os consórcios (06 de abril de 2005).

O recorte temático, por sua vez, buscará localizar este estudo na órbita das questões relativas ao município brasileiro. Assim, as questões específicas deste recorte estão diretamente relacionadas com as formas de cooperação entre municípios, ou nos termos adotados por Rocha e Faria (2004), relacionadas com as formas de "desfragmentação" das ações municipais no Brasil.

Parte-se do pressuposto de que os municípios brasileiros, no período pós-constituição (1988) agem de forma quase autárquica e fragmentada. Apesar desse "hobbesianismo" municipal (Mello, 1996), há uma série de instrumentos institucionais e de ações efetivas levadas a cabo pelos municípios brasileiros, no sentido de ação coletiva, conjunta e cooperada entre eles, dentre os quais, os consórcios intermunicipais.

Por meio deste recorte temático, portanto, buscar-se-á apresentar a história recente da prática da ação consorciada entre municípios. Apesar da Constituição Federal de 1988 ser o marco institucional da análise ora proposta, há peculiaridades dignas de nota tanto no que diz respeito, em termos mais gerais, à ação cooperada entre municípios; quanto, em termos mais específicos, no que diz respeito à pratica do consórcio entre municípios. Deste modo, será necessário retroagir no tempo e buscar os antecedentes da prática do consórcio no Estado de São Paulo, nos idos de 80, quando da época do Governo Montoro ${ }^{3}$.

Em seguida, ainda no que diz respeito ao recorte temático, serão apresentadas a definição de consórcios intermunicipais bem como outros mecanismos institucionais que propiciam a cooperação ou da ação "desfragmentada" entre os municípios. Assim, por meio deste recorte temático, será possível conhecer e diferenciar os mecanismos de cooperação entre municípios, tais como os referidos Consórcios Intermunicipais, as Regiões Metropolitanas, as Regiões de Desenvolvimento Econômico, dentre outros.

\footnotetext{
${ }^{3}$ Foi realizada busca de informações em bases de dados de outros estados, tais como IPARDES (PR), Fundação João Pinheiro (FJP-MG), dentre outras. Em nenhuma delas, entretanto, foi encontrada referência à formação de consórcios ao longo dos anos 80 .
} 
Em seguida, por meio deste recorte temático serão apresentados e discutidos brevemente os dados mais recentes sobre Consórcios Intermunicipais no Brasil, bem como o debate recente sobre o tema.

Os dados mais gerais sobre os consórcios, organizados por setores, localização no território brasileiro e porte dos municípios consorciados, tomarão como base as informações do Instituto Brasileiro de Geografia e Estatística (IBGE).

O debate temático, por sua vez, será apresentado como fruto de uma pesquisa bibliográfica por meio da qual foi possível rastrear em bases de experiências "inovadoras" de gestão pública de Estados, Municípios e Povos Indígenas, algumas experiências de Consórcios Intermunicipais.

Finalmente, ainda por meio do recorte temático, serão apresentados os principais "marcos" institucionais que fortalecem a prática do consórcio entre municípios.

Finalmente, por meio do recorte empírico buscar-se-á analisar o tema dos consórcios intermunicipais à luz, principalmente, da teoria da formação de agendas governamentais, mas também considerar-se-á referenciais teóricos relacionados ao capital social e à escolha racional, em experiências concretas surgidas no Brasil ao longo dos anos $\mathbf{9 0 .}$

Os Consórcios Intermunicipais analisados ao longo deste trabalho são os seguintes:

- Consórcio Intermunicipal de Produção e Abastecimento de São Luís (CINPRA-MA);

- Consórcio Intermunicipal das Bacias do Alto Tamanduateí e Billings (Grande ABC);

- Consórcios de Saúde dos Municípios de Minas Gerais.

Em termos metodológicos, portanto, optou-se pela realização de estudos de caso comparados.

A hipótese central é a de que os consórcios intermunicipais dependem de dinâmicas locais. De acordo com Kingdon (1995), a introdução de determinado item na agenda de governo, no caso deste estudo, a 
introdução do consórcio intermunicipal na agenda de vários governos locais (13 prefeituras no caso do CINPRA; e 07 prefeituras no caso do $A B C$ ), depende de dois fatores chaves: um empreendedor de políticas públicas (entrepreuner); e uma janela de oportunidade (policy windows). A hipótese adotada é a de que em cada um desses casos o entrepreuner é fundamental e relevante para explicar os vários casos estudados. Em última instância, acredita-se que alguém, um agente político, seja um agente partidário, candidato a algum cargo eletivo, um burocrata partidário; seja um burocrata de carreira ou indicado para ocupar algum cargo relevante em determinado governo; ou ainda um agente político externo ao governo mas com influência sobre o governo, esse alguém é o entrepreuner ${ }^{4}$.

Quanto à janela de oportunidade, apesar de concordar com a idéia de que ela se abre abruptamente e permanece aberta por pouco tempo, há uma hipótese neste trabalho de que, muitas vezes, há um intenso e demorado processo até que a idéia do consórcio ou de qualquer política pública seja sorvida ou pela sociedade ou pelo menos pela "comunidade política" e finalmente esteja bem posicionada na agenda do governo.

Em outras palavras, a hipótese central deste trabalho é a de que os consórcios intermunicipais resultam de formas peculiares de como se articulam interesses locais em torno de determinados "setores" de políticas públicas, ou seja, em torno da produção e do abastecimento no caso do Maranhão; dos recursos ambientais no caso do Grande $A B C$, e da saúde no caso de Minas Gerais.

Outra hipótese é a de que os Consórcios Intermunicipais são temas relevantes em seus respectivos locais apenas para a "comunidade política" e para determinados setores formadores da opinião pública, mas não atingem o grande público. Assim, cumprem papel importante como mecanismos que permitiram o aumento da rede de relações sociais do que poderíamos chamar de grupo originário, ou seja, do grupo que introduziu a idéia de determinada política pública (no caso específico deste trabalho, do grupo que introduziu, em seus respectivos locais, a idéia do consórcio).

\footnotetext{
${ }^{4}$ Um adágio popular diria que alguém tem que pôr o guizo no pescoço do gato.
} 
Outra hipótese é a de que o consórcio intermunicipal é resultado do aumento de reconhecimento das ações embrionárias levadas a cabo por um pequeno grupo de "crentes", de técnicos e políticos que crêem no consórcio como organização capaz de, por um lado, fortalecer a região em que foi instituído; por outro, fortalecer a idéia do consórcio intermunicipal e o agente político mais próximo do grupo que introduziu a referida idéia em suas respectivas regiões, quais sejam: Jackson Lago, em São Luís (MA); Celso Daniel (Santo André - $A B C$ ); Rafael Guerra (MG), em princípio na região do Alto São Francisco e depois, como Secretário Estadual de Saúde, em todo estado mineiro.

Para verificação das hipóteses enunciadas acima, será de suma importância verificar a gênese da idéia do Consórcio Intermunicipal em cada localidade, bem como sua trajetória, seu percurso, os técnicos e políticos que a levam e adaptam-na às diferentes circunstâncias, qual é o processo de apresentação da idéia e de mobilização e de convencimento de diferentes atores sociais.

Resumidamente, este trabalho tem o objetivo de verificar como os consórcios intermunicipais nascem e se institucionalizam, a partir da análise de casos específicos. A escolha desse objetivo deveu-se à expansão da criação dos Consórcios Intermunicipais como instrumento de cooperação horizontal entre os municípios a partir dos anos 90 em contrapartida à difundida idéia da fragmentação das políticas públicas. Do ponto de vista teórico, além do diálogo permanente com teorias como a da ação racional e do capital social, este trabalho está mais fortemente ancorado no que se convencionou chamar de formação de agendas de governo. 


\section{Capítulo 1:}

\section{Políticas Públicas e Formação de Agendas de Governos Municipais}

\section{Introdução}

A complexidade do tema "Consórcios Intermunicipais" no contexto de um país federativo como é o caso do Brasil exige do pesquisador um esforço redobrado, porque há, por um lado, autonomia de cada um dos membros da federação (estados e municípios), por outro, uma relação de competências e atribuições para cada nível federativo, e finalmente, sistemas de políticas públicas, segundo os quais as diretrizes geralmente são definidas pela União, mas a execução é realizada por meio de uma série de convênios e termos de cooperação técnica entre a União e os entes da federação. Para tratar dos Consórcios Intermunicipais neste contexto federativo é preciso, ao mesmo tempo, reconhecer estes três elementos (autonomia, competências específicas e concorrentes e sistemas de políticas públicas) e buscar entender as forças políticas com as quais cada município, como ator político subnacional, supera a lógica da autonomia como sinônimo equivocado de autosuficiência e procura implementar políticas públicas em conjunto com outros municípios vizinhos.

Do ponto de vista teórico, o tema dos Consórcios Intermunicipais já foi tratado sob duas perspectivas: a da teoria da escolha racional; e a da teoria do capital social.

Será que os dois enfoques isoladamente são suficientes para buscar explicar e entender o complexo processo de surgimento dos consórcios intermunicipais?

Parto da idéia de que cada uma das teorias, ainda que metodologicamente muito distintas, contribuem, de forma complementar uma com a outra, para formar um conjunto explicativo do fenômeno que é o surgimento dos Consórcios Intermunicipais.

Assim, neste capítulo buscar-se-á identificar as escolas de pensamento neo-institucionalista que têm interface com as duas teorias enunciadas acima e com a teoria da formação da agenda de governos. 
Considero que o enfoque teórico da formação de agendas de governo está na fronteira entre duas tradições da Ciência Política: aquela que busca entender o papel do Estado; e aquela preocupada especificamente com as ações de governo.

De antemão deve-se esclarecer que, embora se admita a complementaridade dessas teorias (a da escolha racional, a do capital social e o da formação de agendas), o foco central utilizado neste trabalho para o entendimento dos consórcios intermunicipais no Brasil, no período que se estende de 1988 a 2005, é o da formação das agendas de governo.

Os estudos realizados no Brasil que, embora tratassem de outros temas e de outros objetos empíricos, e privilegiaram, teoricamente, a idéia de formação de agendas (Fuks, 2001; Capella, 2004; França, 2007) o fizeram com foco nos Governos Estaduais e Federais.

Fuks (2001), preocupou-se em verificar como o tema ambiental entrou na agenda do Governo do Rio de Janeiro. Capella (2004), por sua vez, preocupou-se com a Reforma da Administração Pública proposta e realizada pelo Governo Federal no período em que o Brasil foi presidido por Fernando Henrique Cardoso (1995-2002). Finalmente, França (2007), preocupou-se com a política do setor elétrico empreendida pelo segundo Governo FHC (19992002) e pelo primeiro Governo Lula (2003-2006).

Diferentemente desses autores, neste trabalho, buscar-se-á refletir e analisar como os Consórcios Intermunicipais surgem nas agendas de determinados governos locais.

Deste modo, neste capítulo buscar-se-á desenvolver uma reflexão sobre a formação das agendas governamentais. No caso proposto, buscar-se-á analisar o processo de formação da agenda do governo por meio de um arcabouço teórico que enfatiza fluxos dinâmicos de tomadas de decisão.

Este capítulo será estruturado, além esta introdução e da conclusão, em quatro seções, cada qual com o seguinte objetivo:

- Política e Políticas Públicas, com o objetivo de localizar o enfoque aqui adotado (formação de agendas de governo) no campo da ciência política e sua interface com as políticas públicas; 
- Instituições e Atores Políticos, com o objetivo de situar as teorias relacionadas com o surgimento de consórcios em relação às teorias neo-institucionalistas;

- O Ciclo Dinâmico das Políticas Públicas, com o objetivo de apresentar e discutir cada fase do Ciclo das políticas públicas apresentando-os como partes de uma Dinâmica no processo de concepção de Políticas Públicas (articulada com o Jogo da Política);

- Formação da Agenda de Governo: primeira fase do Ciclo? Esta seção tem o objetivo de apresentar e discutir uma teoria de formação da agenda de governo a partir dos estudos de Kingdon (1995).

\section{Política e Políticas Públicas}

Como foi dito, considera-se que este trabalho se situa na fronteira entre duas tradições da ciência política: uma tradição mais diretamente interessada em entender o papel do Estado e suas instituições (principalmente o Governo) e seus sistemas (como sistema político e eleitoral, por exemplo); e outra tradição mais relacionada com um campo de conhecimento diretamente interessado em entender "a ação dos governos".

Em outras palavras, o campo de conhecimento de uma das tradições (a tradição mais européia) $)^{5}$ está preocupado em responder às questões que dizem respeito a quem manda, como manda e por que manda? O campo de conhecimento da política pública, de acordo com uma tradição mais americana, por sua vez, está preocupado em saber o que o governo faz? Por que determinado governo opta por fazer determinada política? Qual a diferença isso traz? (Dye, 1984).

Segundo Souza (2006), a política pública desenvolveu-se mais intensamente no âmbito da segunda tradição (tradição americana) "sem estabelecer relações com as bases teóricas sobre o papel do Estado, passando direto para a ênfase nos estudos sobre a ação dos governos".

\footnotetext{
${ }^{5}$ Estudo interessante sobre a perspectiva européia de analisar políticas públicas foi realizado por Muller (1990).
} 
Este trabalho não busca estabelecer as relações entre política e políticas públicas, que historicamente não foram construídas. Entretanto, ainda que não haja a referida relação histórica, compreender a relação entre negociações políticas entre agentes de partidos políticos diferentes, a relação desses agentes políticos com o corpo técnico de instituições diretamente vinculadas a âmbitos estatais diferentes (União, Estado e Municípios) são elementos essenciais para compreender o processo de gênese e implantação de um Consórcio Intermunicipal, encarado tanto como nova institucionalidade quanto como uma política pública.

Assim, o campo de conhecimento que interessa a este trabalho está na fronteira ou na interface entre as duas tradições da ciência política, ou seja, num campo de conhecimento preocupado em entender a política pública como ação de governo imersa num intenso jogo político ${ }^{6}$.

\section{Instituições e Atores Políticos}

Nesta seção, dada a ampla aceitação da teoria neo-institucionalista na ciência política brasileira, proponho identificar a teoria da escolha racional, a teoria do capital social e a teoria da formação de agenda de governo com as três clivagens neo-institucionalistas.

Busca-se identificar campos de referência para, assim, facilitar o uso de conceitos de atores e de instituições, dado que, neste trabalho, se aceita a priori que são os atores individuais que operam a política, condicionados, é bem verdade, por constrangimentos de toda ordem (legal, social e político), mas também por concepções de mundo e por idéias; e são as instituições, elementos constitutivos do Estado, construídas e constrangedoras dos atores que as constroem.

Não se trata de buscar consensos, similaridades e diferenças entre as teorias neo-instituiconalistas, mas simplesmente de ilustrar a relevância dos atores e das instituições como ferramentas analíticas que facilitam 0 entendimento empírico de fenômenos sociais.

\footnotetext{
${ }^{6}$ Souza (2006) elabora revisão da literatura sobre políticas públicas buscando articular, por um lado, as políticas públicas no campo da ciência política, exatamente nesta área de fronteira das duas tradições (européia e americana); e no campo da administração pública, buscando articular, por meio da política pública, os campos da ciência política e da administração pública.
} 
Segundo Hall e Taylor (2003), os estudiosos das ciências sociais que adotam as instituições como elementos centrais de seus trabalhos, podem ser classificados em três grupos: Neo-institucionalistas da Escolha Racional, Neoinstitucionalistas Sociológicos e Neo-institucionalistas Históricos.

Para Hall e Taylor (2003), apesar das diferenças metodológicas, essas três correntes de pensamento passaram a incluir as regras do jogo como variáveis determinantes dos fenômenos sociais. Para o autor, os neoinstitucionalistas, independentemente de suas diferenças, buscam responder duas questões estruturantes de suas pesquisas: como construir a relação entre instituição e comportamento dos atores; e como explicar o processo pelo qual as instituições surgem ou se modificam. Para o caso específico deste trabalho, dadas as instituições existentes, buscar-se-á compreender como surgem os Consórcios Intermunicipais.

Os Neo-institucionalistas da Escolha Racional preocupam-se essencialmente com a racionalidade (concebida a priori) que orienta os agentes políticos individuais na maior parte das ações políticas, bem como com as estratégias adotadas por eles.

Para esses autores, "se os postulados clássicos da Escola da Escolha Racional são exatos, deveria ser difícil de reunir maiorias estáveis para votar leis no Congresso norte-americano, onde as múltiplas ordens de preferência dos legisladores e o caráter multidimensional das questões deveriam rapidamente gerar ciclos, nos quais cada nova maioria invalidaria as leis votadas pela maioria precedente" (Hall e Taylor, 2003: 202). Para explicar esse paradoxo, presente não apenas no Congresso americano, mas em diversas ações de cunho político e econômico, os teóricos da Escolha Racional foram buscar respostas nas instituições. As características da teoria neoinstitucionalista na perspectiva da Escolha Racional são as seguintes:

1. Pressupostos comportamentais;

2. Série de dilemas de ação coletiva;

3. Papel da interação estratégicas dos atores envolvidos em determinada situação política ou econômica; e 
4. Origem das instituições calcada em acordos voluntários entre os interessados ${ }^{7}$.

Assim, é fundamental identificar os atores presentes, as arenas nas quais eles atuam, os interesses dos atores envolvidos e as estruturas de estímulos e punições.

Com relação aos pressupostos comportamentais, Hall e Taylor (2003) salientam que, em geral, os teóricos da Escolha Racional "postulam que os atores envolvidos em certa ação possuem um conjunto determinado de preferências e se comportam de forma utilitarista para maximizar suas satisfações, dadas suas preferências, e seguindo um alto nível de cálculos estratégicos".

Os dilemas de ação coletiva são decorrentes das interações entre os atores envolvidos, cada qual com sua escala de valores e preferências. Os dilemas de ação coletiva são situações nas quais os indivíduos ao agirem de acordo com seus valores e suas escalas de preferências, buscando maximizar seus níveis de satisfação, podem produzir um resultado sub-ótimo (em termos parettianos) para a coletividade ${ }^{8}$.

A interação estratégica dos atores, por sua vez, condiciona o comportamento de cada ator, que não é determinado por forças históricas impessoais, mas por cálculo estratégico de custo-benefício. Os cálculos, aliás, consideram as possibilidades e os prováveis comportamentos dos atores envolvidos.

A interação dos atores e os parâmetros para realização dos cálculos, bem como as possibilidades de ação são estruturadas pelas instituições, enquanto conjunto de regras.

Nestes termos, para os propósitos deste trabalho, quais seriam as regras existentes que induziriam, ou não, a formação de Consórcios Intermunicipais?

\footnotetext{
${ }^{7}$ Hall e Taylor (2003) apresentam uma série de exemplos de acordos voluntários para estruturação das instituições, dentre os quais, os regulamentos do Congresso americano explicados em função dos ganhos obtidos por mudanças pelos seus membros.

${ }^{8}$ O Dilema do Prisioneiro é um caso clássico. Para saber mais sobre Teoria dos Jogos e Estratégias Competitivas, ver Pindyck, R. e Robinfeld, D. (1994).
} 
Deste modo, o que se observa é que esta escola de pensamento detalha com maior precisão o papel do ator individual imerso no sistema político e tem, muitas vezes, pressupostos nem sempre verificados nos trabalhos empíricos, dado que muitas vezes nem sempre os atores têm plenitude de informação e agem estrategicamente buscando otimizar suas preferências, desconsiderando os fatores históricos e, principalmente, as crenças, as idéias que movem ou, pelo menos, influenciam a ação política dos atores.

Ainda assim cabe a pergunta: a abordagem neo-institucionalista da escolha racional ajuda a explicar o surgimento dos Consórcios Intermunicipais?

Sim. Em dois estudos Teixeira, Mac Dowell e Bugarin (2002a, 2002b) lançam mão dos argumentos do neo-institucionalismo da escolha racional para explicar o surgimento e a manutenção dos Consórcios Intermunicipais.

Para estes autores, os consórcios intermunicipais surgem como resultado de uma série de estímulos exógenos ao território no qual está sendo criado. O estímulo é vertical, uma vez que advém tanto da União quanto do Estado. Os consórcios articulam-se em torno de um território e de um setor. Ou seja, os consórcios, por meio de um estímulo externo são capazes de articular interesses setoriais no território.

O setor da saúde é o que mais avançou em termos da constituição de um Sistema Único de Saúde em Rede Nacional. Para a consecução deste sistema, as normatizações foram sendo alterada para conferir maior precisão às atribuições dos entes federados e estabelecer uma maior vinculação entre a quantidade e os tipos de serviços públicos prestados e o volume de recursos transferidos para a instância prestadora dos serviços ${ }^{9}$. No entanto, como qualquer cidadão que mora em um município pode utilizar os serviços de saúde financiados por outro município, gerando o "efeito carona", o Ministério da Saúde, dentre outras medidas, passou a estimular a constituição de "Consórcios Intermunicipais de Saúde" (CIS) para evitar o "efeito carona" e

\footnotetext{
${ }^{9}$ Dado que os usuários podem se deslocar de uma área de atendimento para outra, é comum que neste setor (setor saúde) haja o que Olson (1965) chamou de "efeito carona". O "efeito carona" consiste no beneficiamento de determinado agente pelo serviço prestado por outrem sem a devida remuneração. Segundo os autores da "Escolha Racional", trata-se de um problema típico dos bens públicos, relativo à não exclusividade do bem. Em outras palavras, quando se trata de bens públicos, uma vez disponíveis, não há como excluir os cidadãos de seus usos.
} 
evitar o desperdício da duplicidade de ações ou de investimentos, como a construção de hospitais desnecessários. Por meio dos consórcios, conseguese ganhos de escala e inibição do "efeito carona".

As Leis específicas que tratam do Sistema Único de Saúde (Lei 8080/90 e Lei 8142/90) dizem que, além dos municípios, entes da Federação, os Consórcios também podem integrar formalmente o SUS.

Além das duas Leis, de acordo com a Norma Opercional Básica do Sistema Único de Saúde (NOB SUS 01/96), a criação de Consórcios Intermunicipais de Saúde cria condições favoráveis para que o município sede venha a assumir as responsabilidades pela gestão plena do seu sistema de saúde.

Finalmente, o Ministério da Saúde, ao elaborar o Plano de Ações e Metas Prioritárias para 1997/1998, estabeleceu que a criação dos Consórcios Intermunicipais e Interestaduais de Saúde seriam estimulados, uma vez que o próprio Ministério da Saúde acredita que os CIS seriam capazes de promover a melhoria da qualidade dos serviços de saúde.

Teixeira, Mac Dowell e Bugarin (2002b) fizeram uso da teoria da agência para estudar "os mecanismos que podem ser implementados a fim de gerar incentivos adequados à sustentabilidade dessa forma de associação". Por meio da formalização de modelos matemáticos, os autores concluíram que mecanismos de estímulo "verticais", ou seja, advindos de outras esferas de governo, são fundamentais para a constituição e manutenção dos $\mathrm{CIS}^{10}$.

De acordo com os referidos estudos e verificação empírica tanto do crescimento do número de CIS quanto das alterações institucionais para induzir suas constituições, há indicações fortes de que os estímulos institucionais funcionaram para o caso dos CIS. Grosso modo, pode-se dizer que há uma relação direta entre os estímulos institucionais e a formação de $\mathrm{CIS}^{11}$.

\footnotetext{
${ }^{10}$ Maiores detalhes sobre teoria dos contratos aplicada aos consórcios, ver: TEIXEIRA, Luciana, MAC DOWELL, Maria Cristina e BUGARIN, Maurício (2002).

${ }^{11}$ A indução institucional pode ocorrer por meio de estímulos e ameaças. No Rio Grande do Sul (RS) por exemplo, depois da bem sucedida experiência do Consórcio Intermunicipal de Tratamento de Resíduos Sólidos Urbanos articulado pelo município de Três Passos, o Ministério Público do Estado passou a exigir que outros municípios acabassem com os depósitos irregulares ("lixões"), sob pena de multa e processo administrativo. Nesse caso, portanto, não houve propriamente estímulo, mas ameaça e punição. Nessa medida, a indução
} 
Deve-se notar, entretanto, que nem sempre o estímulo veio somente das estruturas criadas exogenamente. Muitas vezes, ainda que haja estrutura de estímulos institucionais exógenas ao território, se não há um "animador" local, um militante da causa ou mesmo um ator racional com informações plenas sobre as vantagens e desvantagens do Consórcio capaz de tomar o que poderia se considerar uma decisão racional acerca do assunto, o Consórcio não se efetiva. $O$ agente racional em uma das pontas do processo apenas, não é capaz de induzir a instituição de consórcios por todos os lugares. É preciso o ator racional induzindo o processo na esfera federal, e é preciso também um ator racional capaz de entender a referida racionalidade em cada localidade. Do contrário, ocorre, ao longo do processo, uma espécie de "dissonância cognitiva".

Assim, voltando ao raciocínio proposto por Hall e Taylor (2003), o isomorfismo institucional explicaria apenas uma parte do processo de tomada de decisão quanto a constituir ou não um consórcio intermunicipal. Outra variável que auxiliaria na explicação do surgimento dos consórcios intermunicipais seria a atmosfera social e política de cada localidade no que diz respeito à introdução dessa proposta de resolver determinados problemas de ação coletiva por meio da cooperação intermunicipal.

Assim, a perspectiva neo-institucionalista sociológica contribui com a explicação do surgimento de consórcios intermunicipais na medida em que introduz valores, símbolos e a legitimidade sociopolítica como variáveis explicativas de processos de tomadas de decisão quanto a introdução ou alteração de instituições na vida cotidiana das pessoas.

Os neo-institucionalistas sociológicos sustentam que muitas formas e procedimentos institucionais utilizados pelas organizações modernas não foram adotadas simplesmente porque são mais eficazes. Muitas organizações adotam determinadas formas e procedimentos por determinação de aspectos culturais de seus membros.

Os teóricos dessa escola de pensamento estão preocupados em explicar os motivos pelos quais determinadas organizações adotam um saber mais sobre o referido consórcio, ver CALDAS, Eduardo de Lima (2003). 
conjunto de formas, procedimentos e símbolos institucionais. Talvez a principal característica que confere originalidade a essa corrente de pensamento seja a tendência em definir instituições de forma mais ampla e genérica, incluindo além de regras, procedimentos e normas formais, os sistemas de símbolos, os esquemas cognitivos e os modelos morais que fornecem determinada "significação" para as ações humanas.

A amplitude conceitual desta escola de pensamento permite-nos dizer como o fez Halll e Taylor (2003: 210) que, "a relação que liga o indivíduo e a instituição repousa, portanto, sobre uma espécie de "raciocínio prático" pelo qual, para estabelecer uma linha de ação, o indivíduo utiliza os modelos institucionais disponíveis ao mesmo tempo que os confecciona”.

Então, a pergunta que se faz para relacionar as características do neoinstitucionalismo sociológico com o objeto deste trabalho é a seguinte: a abordagem neo-institucionalista sociológica ajuda a explicar o surgimento dos Consórcios Intermunicipais?

Sim, de acordo com o raciocínio proposto pelos neo-institucionalistas sociológicos, as instituições, em função de aspectos culturais construídos ao longo da sua história institucional, moldam a ação dos indivíduos; e não como propugnam os adeptos da teoria da escolha racional, em razão da lógica e estratégica da ação dos atores. Isso, evidentemente não significa que os indivíduos não tenham intenções ou não tenham racionalidade. O que os teóricos do neo-institucionalismo sociológico dizem é que "aquilo que um indivíduo tende a considerar como uma "ação racional" é ele próprio um objeto socialmente constituído".

Assim, para os estudiosos desta corrente de pensamento, as regras, procedimentos e normas formais, os sistemas de símbolos, os esquemas cognitivos e os modelos morais que dão coesão à sociedade, são determinantes para que os membros de determinada sociedade criem relações de confiança ou não entre si, e estabelecem formas de ação conjuntas, como é o caso da formação dos Consórcios Intermunicipais.

A participação de um município em determinado consórcio, nesta medida, muitas vezes não é propriamente um ato deliberado de ação racional 
no sentido lato do termo em que esta ação "maximiza" a função utilidade do ator político ${ }^{12}$.

Finalmente, ainda de acordo com as reflexões de Hall e Taylos (2003), pergunta-se o que caracteriza o neo-institucionalismo histórico? Os neoinstitucionalistas históricos buscam explicar a organização institucional da comunidade política e das estruturas econômicas como resultado de interesses conflitantes, no qual determinados atores são privilegiados em detrimento de outros. Nesse aspecto, portanto, consideram que é a assimetria de poder entre os "atores" envolvidos nos processos políticos é uma variável importante, e associam essa assimetria ao funcionamento e ao desenvolvimento de instituições ${ }^{13}$.

Os autores desta corrente de pensamento consideram também que a organização das instituições são os principais fatores estruturantes do comportamento coletivo. Para essa corrente de pensamento, segundo Hall e Taylor (2003: 196), "instituições são procedimentos, protocolos, normas e convenções oficiais e não oficiais inerentes à estrutura organizacional da comunidade política ou da economia política".

Esses autores associam as instituições às organizações e às regras editadas pelas organizações formais. Finalmente, deve-se considerar que esses autores tendem a situar o surgimento e o desenvolvimento das instituições em uma cadeia de causalidades que possibilitam incorporar outros fatores explicativos.

O neo-institucionalismo histórico destaca, dentre outros pontos, a capacidade que a organização institucional tem para filtrar e modelar o comportamento coletivo.

\footnotetext{
${ }^{12}$ Diferentemente do que se observou no caso do neo-institucionalismo da escolha racional, em que há estudos sobre a formação de consórcios que se respaldam no conjunto de argumentos da referida vertente neo-institucionalista; no caso do neo-institucionalismo sociológico não encontrei estudos empíricos que explicitamente utilizasse se respaldasse no conjunto de argumentos dessa vertente neo-institucionalista.

${ }^{13} \mathrm{O}$ neo-institucionalismo histórico é uma corrente de pensamento que nasceu contrapondo-se às análises estruturais e funcionalistas, mas que, ao mesmo tempo, aceitou a concepção de que a comunidade política é um sistema global composto por parte que interagem. Apesar de aceitarem tal concepção, os institucionalistas históricos acreditam que as características sociais, psicológicas ou culturais dos indivíduos são os parâmetros fundamentais que regem o funcionamento do sistema geral.
} 
Tais instituições, entendidas como "procedimentos, protocolos, normas e convenções oficiais e oficiosas inerentes à estrutura organizacional da comunidade política ou da economia política se apresenta por meio de estatutos, convenções e regras pré-estabelecidas". Neta medida o pacto de fundação é fundamental, pois é neste momento que se moldam as instituições.

Nesta perspectiva, as instituições moldam comportamento. Os atores, que no ato de fundação, definem as regras, passam a ser constrangidos pelas regras definidas e pelas supostas conseqüências de suas ações, o que faz com que eles refaçam seus cálculos estratégicos.

Os institucionalistas históricos mesclam um conjunto de elementos, diferenciando-os e articulando-os, como por exemplo, atores racionais, cálculos estratégicos, instituições, organizações. É fundamental ressaltar que, para esta escola de pensamento "o comportamento do ator é determinado não por forças históricas impessoais, mas por um cálculo estratégico".

Assim, retomo a idéia inicial de situar este trabalho diante dos enfoques neo-institucionalistas, reafirmando que os papéis desempenhados pelas instituições e pelos atores políticos são fundamentais na intermediação de conflitos e interesses presentes nos processos de formação de agenda.

Para os propósitos deste trabalho que traz maior dose de influência dessa última vertente neo-institucionalista, não se pretende comparar exaustivamente as três vertentes de pensamento neo-institucionalista, mas tãosomente resgatar em cada uma dessas vertentes, elementos úteis para analisar o papel dos atores e das instituições no longo processo de formação dos consórcios intermunicipais, e mais especificamente no chamado processo pré-decisório, ou seja, no processo por meio do qual, determinadas situações passam a ser vistas como problemas a serem equacionados por meio de políticas públicas.

Assim, do neo-institucionalismo da escolha racional ganham destaque para os propósitos deste trabalho a idéia do ator individual que, muitas vezes, ao longo dos processos políticos é quem leva adiante determinada idéia e cumpre papéis importantes de articulação entre grupos políticos distintos; e a idéia dos estímulos institucionais. 
Do neo-institucionalismo sociológico apreende-se a idéia de que as instituições podem condicionar o comportamento dos indivíduos (não no sentido da "racionalidade" estratégica proposta pelos neo-institucionalistas da escolha racional), mas a partir da introjeção de novos valores, de símbolos e da produção de novas legitimidades sociopolíticas.

O neo-institucionalismo histórico é a vertente mais pertinente para situar este trabalho, dado que a referida vertente de análise neo-institucionalista permite-nos compreender a construção institucional de determinada política pública imersa num ambiente em que as forças políticas estão em permanentes disputas, ou seja, para o caso específico deste trabalho, permitenos compreender a inserção de determinada política pública (consórcios intermunicipais) na agenda de governo a partir da ação dos mais diversos atores políticos que estão em disputa entre si.

Finalmente, devo considerar que as reflexões propostas neste trabalho destacam as relações de poder e o jogo político inerentes a todo processo de tomada de decisão no que concerne a políticas públicas. Assim, este trabalho se situa em um território de reconhecimento da relação assimétrica de poder, na aceitação de que os resultados são influenciados por contingências sociais e políticas, na recusa ao exclusivismo racional ou ao culturalista para explicar os comportamentos, e no entendimento de que o Estado, seja em função dos governos ou de outras instituições, participam do jogo político e detém interesses próprios, que não necessariamente condizem com as vontades e interesses de determinadas classes ou com as elites tradicionais.

\section{O Ciclo Dinâmico das Políticas Públicas}

As políticas públicas podem ser analisadas ou a partir de um setor específico (educação, saúde, habitação, dentre outros) ou a partir de seu ciclo de vida. No caso específico desta tese, pretende-se olhar as políticas públicas a partir de seu ciclo de vida.

Souza (2006) faz uma espécie de genealogia das políticas públicas iniciada com quatro autores: Laswell, Simon, Lindblom e Easton. 
Qual a contribuição de cada um desses autores para a estruturação e organização do campo de conhecimento que trata das políticas públicas?

Segundo Souza (2006), Laswell (1936) introduz a expressão "análise de política pública" para forçar um diálogo entre acadêmicos, grupos de pressão e governo. Simon (1942), ao questionar a racionalidade irrestrita do tomador de decisão, afirma que os limites impostos aos tomadores de decisão são decorrentes da incompletude de informação e do auto-interesse dos próprios tomadores de decisão; e que estes mesmos limites podem ser superados pela criação de instituições que induzam o comportamento dos tomadores de decisão para os resultados programados. Nesta medida, o autor situa a análise da política pública em um ambiente em que as forças políticas e sociais estão em permanente disputa. Lindblon $(1959,1979)$ incorpora variáveis políticas, tais como o papel das eleições, das burocracias, dos partidos políticos e dos grupos de pressão, na análise das diversas fases dos processos decisórios relativos à formulação e análise das políticas públicas. Finalmente, Easton (1965) analisa as políticas públicas como um sistema que recebe imputs dos partidos políticos, da mídia e dos grupos de pressão; e gera outputs.

Em seguida, Souza (2006) apresenta modelos de formulação e análise de políticas públicas propostos por Lowi (1964, 1972), Lindblon (1979) e Wildavsky (1992).

Segundo Lowi (1964, 1972), "cada tipo de política pública encontra diferentes formas de apoio e de rejeição e que as disputas em torno de sua decisão passam por arenas diferenciadas".

Lindblon (1979) e Wildavsky (1992), ao apresentarem seus modelos de análise de políticas públicas, destacam que os recursos governamentais direcionados para as políticas públicas não partem do zero, mas são incrementadas ano a ano, independentemente das alterações substantivas ocorridas com as próprias políticas e programas governamentais.

Em seguida, Souza (2006) apresenta a idéia de ciclo da política pública desenvolvida ao longo dos anos 70. Para autores como Laswell (1971), May e Wildavsky (1977), DeLeon e Brewer (1983), Hogwood e Gunn (1984) e Anderson (1984) a formulação e implementação de políticas públicas 
constituem-se em processos desenvolvidos em etapas, cada qual com seus atores, restrições, decisões, desenvolvimento e resultado próprios, capaz de influir e ser influenciada por outras políticas.

Lasswell (1971) analisou o referido processo como um "modelo de processo de tomada de decisões" com sete fases e sete resultados.

May e Wildavsky (1977) preferiram falar em "ciclo político" e organizou-o em "momentos" - fixação da agenda, análise da questão, implementação, avaliação e término.

DeLeon e Brewer (1983) reelaboraram o modelo de Lasswell em seis fases.

Hogwood e Gunn (1984) também dividiram o processo em nove etapas que se inicia em reformular com clareza e objetividade o problema estabelecido na agenda e termina com avaliação, manutenção ou suspensão da política.

Anderson (1984), por sua vez, divide o processo em cinco fases que se iniciam com a identificação do problema e formação da agenda, formulação, adoção, implementação e avaliação da política pública adotada.

Esses clássicos das políticas públicas permitem-nos observar determinadas características que Ihes são peculiares: todos admitem a existência de um problema, embora não o definam ou o caracterizem como tal e todos analisam o processo de formulação e implementação de políticas públicas como estanques e desarticulados dos processos políticos (politics).

Villanueva (1993) diz que essas fases do processo de elaboração e implementação de políticas públicas, ao longo do tempo, ganham ênfases diferentes, de acordo com as áreas de conhecimento dos pesquisadores: politólogos preferem estudar a formação da agenda de governo; administradores públicos, a implementação das referidas políticas; e os economistas, a construção e a seleção de opções políticas.

Voltando à linha genealógica proposta por Souza (2006), deve-se considerar as contribuições de Cohen, March e Olsen (1972) que desenvolvem o modelo da "lata de lixo" (garbage can) segundo o qual os governos, incapazes de atenderem todas as demandas, vão entulhando a agenda 
institucional e formal (Coob e Elder, 1972) de propostas advindas dos mais variados setores, até o momento em que começa a juntar os interesses colecionados na agenda e a propor soluções conjuntas.

Este emaranhado de demandas que entulha a agenda do governo constitui-se no que Cohen, March e Olsen (1972) chamaram de "anarquias organizadas".

As "anarquias organizadas" possuem três características básicas: (1) preferências problemáticas, imprecisas, desordenadas e voláteis; (2) tecnologias e procedimentos para a composição de determinada política pública a partir de demandas existentes não são claras, mas pelo contrário, são incompreendidas pelos próprios membros da organização, tem muita tentativa erro-acerto, analogias, saber convencional e intuição; e (3) participação é fluida, com diversos graus de motivação e de compromissos.

Conseqüentemente, o processo decisório carcteriza-se por uma alta volatilidade e pouca precisão.

Desconsiderando que o processo de tomada de decisão seja semelhante a um jogo de loteria, decidir significa, em muitos casos, colocar a mão em uma lata de lixo para criar, a partir dos elementos ali fragmentados, dispersos e heterogêneos, algumas respostas integradas para as demandas de políticas públicas previamente realizadas. Decidir é compatibilizar os elementos que se tem em mãos. O processo decisório de uma "anarquia organizada" se caracteriza então por ser uma coleção de decisões que estão em busca de um problema; de questões e sentimentos que estão em busca de ocasiões de decisões para se configurar em política pública; de soluções em busca de questões que podem responder e de decisões em busca de trabalho.

O processo decisório para construir soluções a essa "anarquia organizada" resulta da confluência de quatro correntes relativamente independentes: as pessoas, os problemas, as soluções e as oportunidades.

A partir destas idéias, por meio das quais Cohen, March e Olsen (1972) desenvolveram o modelo da "lata de lixo" (Garbage Can), Kingdon (2003) começa a traçar as linhas gerais do seu modelo de tomada de decisões que vou chamar de modelo dos três fluxos. 
Kingdon (2003) procura sistematizar os processos sociais concomitantes que buscam interferir na formação da agenda de governo em três eixos: definição do problema (problems stream), processo político (political stream) e elaboração de políticas públicas (policy stream). Os três processos ocorrem de forma mais ou menos independentes e com atores que atuam em múltiplas arenas.

Neste aspecto, Kingdon (2003) desenvolve seu modelo apresentando três fluxos que ocorrem concomitantemente e não sequencialmente. Os três fluxos, aliás, em determinados momentos se unem e, em seguida, se desarticulam.

Assim, para Kingdon (2003) o processo de formação da agenda e de adoção de uma alternativa para execução de determinada política pública não é seqüencial.

Para os propósitos desta tese, o que se pretende é compreender como a idéia dos Consórcios Intermunicipais entram nas agendas dos governos locais, bem como compreender quais são os atores sociais e políticos envolvidos no processo de formação dos referidos governos locais; em quais arenas estes atores atuam e quais são as forças políticas e sociais que influenciam o referido processo.

\section{Formação da Agenda de Governo: primeira fase do Ciclo?}

A introdução dos consórcios intermunicipais na agenda dos governos locais não está situada num campo diferente daquele em que interesses e idéias de diferentes grupos estão em disputa, mas pelo contrário, considera-se que os Consórcios Intermunicipais resultam de formas peculiares de como se articulam interesses locais em torno de suas constituições. Em outras palavras, o que se procura compreender ao longo deste trabalho é como surge a idéia do Consórcio Intermunicipal, que percurso ela faz, quem a carrega e a apresenta a outros atores, que atores são esses, e como eles se mobilizam, independentemente de estímulos externos ou de capital social prévio. Daí, os consórcios intermunicipais dependem de dinâmicas locais. 
De acordo com Kingdon (2003), a introdução de determinado item na agenda de governo (no caso específico deste estudo, a introdução do Consórcio Intermunicipal nas agendas dos governos locais), depende de dois fatores chaves: um empreendedor de políticas públicas (entrepreuner); e uma janela de oportunidade (policy windows).

Kingdon (2003) desenvolve um arcabouço teórico para responder às seguintes questões: por que algumas situações são reconhecidas como problemas públicos e tornam-se importantes para um governo? Como a referida situação torna-se uma problema público que ocupa espaço na agenda de um governo? Em outras palavras, Kingdon (2003) está preocupado em saber como determinado assunto entra na agenda de governo.

Agenda, neste caso, é definida como um conjunto de assuntos sobre os quais tanto o governo quanto as pessoas a ele ligadas gastam seu tempo e concentram sua atenção.

Kingdon (2003) considera que as políticas públicas compreendem quatro processos e concentra sua análise no que se convencionou chamar de processos pré-decisórios.

Os quatro processos independentes e sem ordem de precedência são: o estabelecimento de uma agenda de políticas; um conjunto de políticas públicas alternativas entre si que dão conta de tratar da agenda estabelecida; o processo de escolha entre as alternativas apresentadas; a implementação da decisão.

Em termos empíricos, Kingdon (2003) concentrou sua análise nas políticas públicas, no âmbito do Governo Federal dos Estados Unidos nos setores de saúde e de transporte.

Para caracterizar o governo federal dos Estados Unidos, Kingdon (1995) se apóia no conceito de "anarquia organizada" de March, Olsen e Cohen (1972).

Para Kingdon (1995), as agendas públicas governamentais são resultado da convergência entre três fluxos independentes entre si: o fluxo que define determinada situação como problema (problem); o fluxo que trata de definir as soluções e as alternativas de políticas públicas relacionadas com o 
problema definido no outro fluxo (policy); e o fluxo que trata das decisões políticas (politics).

No primeiro fluxo que trata especificamente dos problemas, o modelo desenvolvido por Kingdon (2003) busca analisar de que forma determinadas situações são reconhecidas como problemas e passam a ocupar lugar de destaque na agenda do governo. Por meio deste fluxo, busca-se saber como determinada situação torna-se um problema público reconhecido pelo governo.

Qual a diferença entre situação e problema? Situação é quando determinado fenômeno que sempre ocorre, mas que nem sempre é reconhecido como questão pública e tampouco como problema a ser enfrentado pelo governo, como por exemplo,

Assim, uma determinada situação só se torna um problema quando formuladores de políticas públicas passam a crer que podem fazer algo a respeito da referida situação. Em outras palavras, problema é algo que recebe reconhecimento público e, ao mesmo tempo, pode ser resolvido por meio de alguma política pública.

E quais são os mecanismos capazes de transformar uma situação em problema? Kingdon (1995) identifica três mecanismos capazes de transformar uma determinada situação em problema: indicadores; eventos, crises e símbolos; e feedback das ações de governo. Esses mecanismos cumprem um papel de garantir notoriedade aos fenômenos.

Os indicadores têm uma longa história. Desde a II Grande Guerra tornou-se intensa a construção de indicadores junto dos governos e órgãos de pesquisa relacionados com os governos. Dentre os indicadores, podemos citar aqueles mais simples, ou de primeira geração, como por exemplo, o Produto Interno Bruto (PIB), os Índices de Inflação, os custos dos programas governamentais, Índice de Mortalidade Infantil, dentre outros; ou ainda índices compostos e mais complexos como, por exemplo, o Índice de Desenvolvimento Humano (IDH).

No entanto, os indicadores apenas indicam, mas não interpretam e não carregam de valor normativo os dados indicados. Então, a seleção de dados, a 
construção do indicador e sua interpretação constroem uma determinada realidade passível de se tornar um problema de políticas públicas.

Assim, indicadores sozinhos não determinam a existência de um problema, mas a interpretação deles auxiliam na identificação ou mesmo na construção de determinado problema público.

Os eventos, crises e símbolos também cumprem importante papel no sentido de chamar a atenção dos governos para determinadas situações alçando-as à condição de problema. Muitas vezes, os problemas já existiam antes de uma eventual crise, mas não tinham posição de destaque nas agendas de governo. A crise, neste aspecto, cumpre papel de elevar o problema previamente existente a uma posição de destaque na agenda de governo.

Finalmente, o feedback sobre programas em fase de desenvolvimento pelos governos constitui o terceiro mecanismo capaz de elevar determinada situação à condição de problema ou ainda de destacar determinado problema no interior das agendas de governo. O feedback é garantido por meio de atividades de monitoramento das políticas já existentes, ou seja, de políticas que agem sobre determinados problemas previamente existentes. Assim, o monitoramento de gastos e o cumprimento de metas e objetivos previamente definidos cumprem papel de levar ou de manter determinado problema no centro das atenções do governo.

Em suma, indicadores, eventos, símbolos ou feedbacks constituem-se em elementos importantes para a formação da agenda do governo, mas não se constituem em mecanismos que alteram o status de determinadas situações transformando-as em problemas governamentais. Assim, situações, por meio de indicadores, eventos, símbolos ou feedbacks podem chamar atenção dos formuladores de política que, ao interpretarem tais elementos, podem transformar a situação em questão num problema governamental.

Assim como os indicadores, o problema governamental também é uma construção social.

Dado que as situações sociais são diversas e o esforço para transformar várias delas em problemas governamentais envolve grupos sociais diferentes, 
com histórias e forças políticas diversas, a forma como se define e articula determinado problema é fundamental para disputar espaços nas agendas do governo ${ }^{14}$.

Figura 1

De Situação a Problema

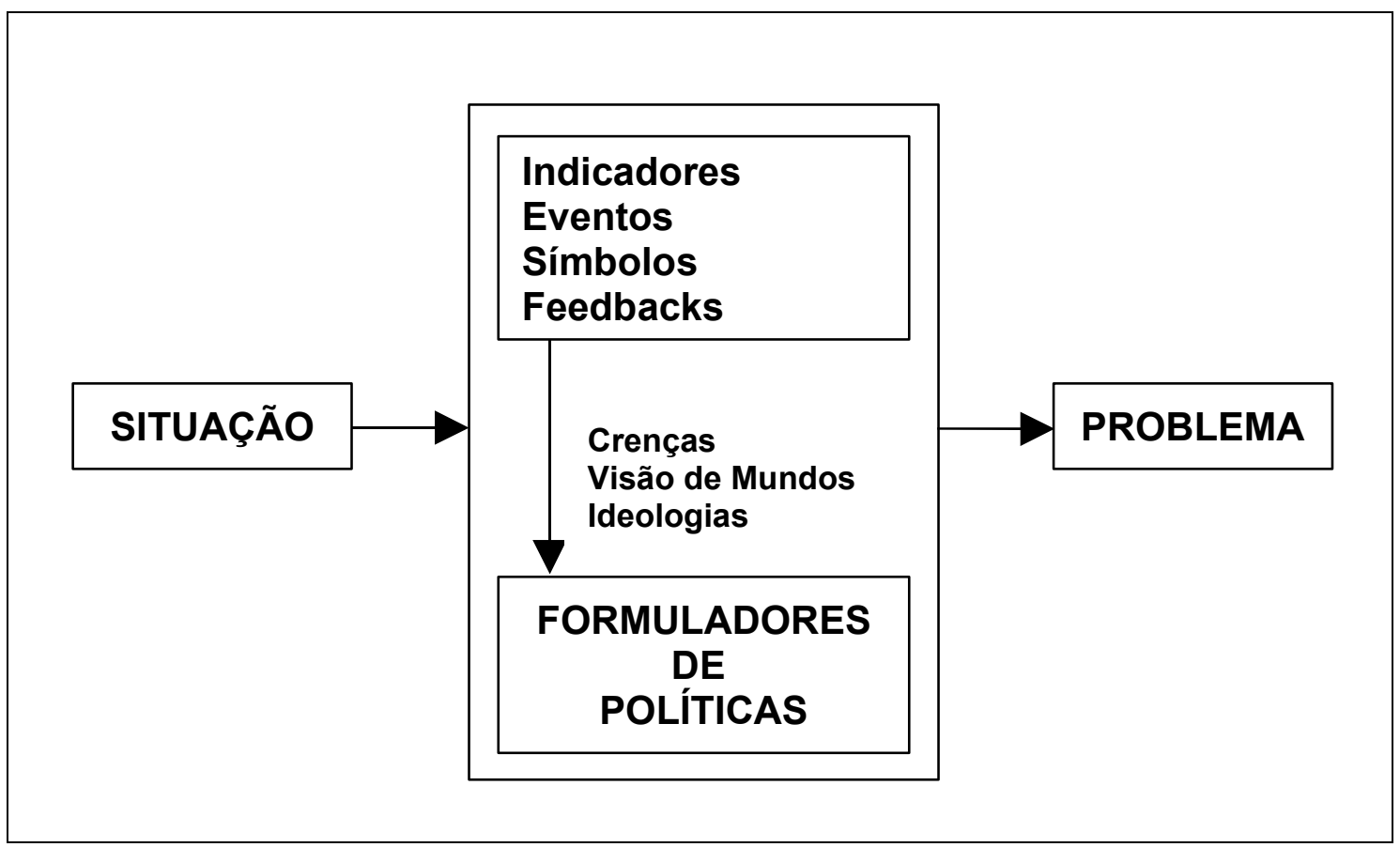

No segundo fluxo, a questão central é saber como são geradas as idéias para solucionar determinados problemas criados. Como problemas e soluções pertencem a fluxos diferentes, não se trata de haver uma solução para um problema previamente definido, mas de haver soluções criadas independentemente de problemas. Assim, problemas e soluções não surgem aos pares.

Para Kingdon (2003), alternativas e soluções são gradas em comunidades de especialistas e flutuam em um "caldo primordial de políticas" (policy primeval soup), até que algumas delas são descartadas, outras são combinadas umas às outras gerando novas propostas, e outras ainda são utilizadas na íntegra.

\footnotetext{
${ }^{14}$ Kingdon (2003) distingue agenda de governo de agenda de decisão. A agenda de governo é uma lista de temas sobre a qual os políticos no governo prestam atenção e pode ser formada em decorrência do reconhecimento de algum problema ou em decorrência do grau de visibilidade que pode ser gerado ou ainda por vontade política isolada. A agenda de decisão é uma lista de temas que está sendo encaminhada para uma decisão efetiva a ser tomada pelo governo. Essa agenda decorre da conjunção dos três fluxos.
} 
Enquanto estão no "caldo primordial de políticas", as idéias que podem se tornar alternativas de políticas públicas são analisadas principalmente no que tange a seus aspectos técnicos, aos custos, e do ponto de vista político, à representação de valores por elas representados e suas interfaces com os atores políticos envolvidos com o tema.

Em seguida, soluções e alternativas (mais densas do ponto de vista político) passam a ser consideradas por outros participantes do processo decisório, por meio de um processo de difusão das idéias segundo o qual os defensores da idéia levam-na para os mais diversos fóruns na tentativa de sensibilizar tanto comunidades de especialistas quanto o público em geral.

Nesta fase do processo há embates em torno da idéia em discussão: discutem-na pesquisadores, assessores parlamentares, especialistas, acadêmicos, funcionários públicos, grupos de pressão, dentre outros. Trata-se de um processo de sensibilização e convencimento. Para Kingdon (2003) as idéias e os processos argumentativos são mais importantes que os grupos de pressão e que os mecanismos que geram estímulos e punições.

Ao longo do processo de difusão ocorre um efeito multiplicador seja dos adeptos seja dos opositores. O fato é que a idéia torna-se um tema público passível de ser debatido e de ser considerado pela imprensa e pelos tomadores de decisão política.

Assim, ao longo do processo, a idéia inicial é, geralmente, alterada, algumas vezes de forma marginal, e outras quase completamente. Ao longo do processo, portanto, geram-se outras tantas alternativas à solução inicialmente debatida.

Figura 2

Alternativas Públicas para Resolução de Problemas 


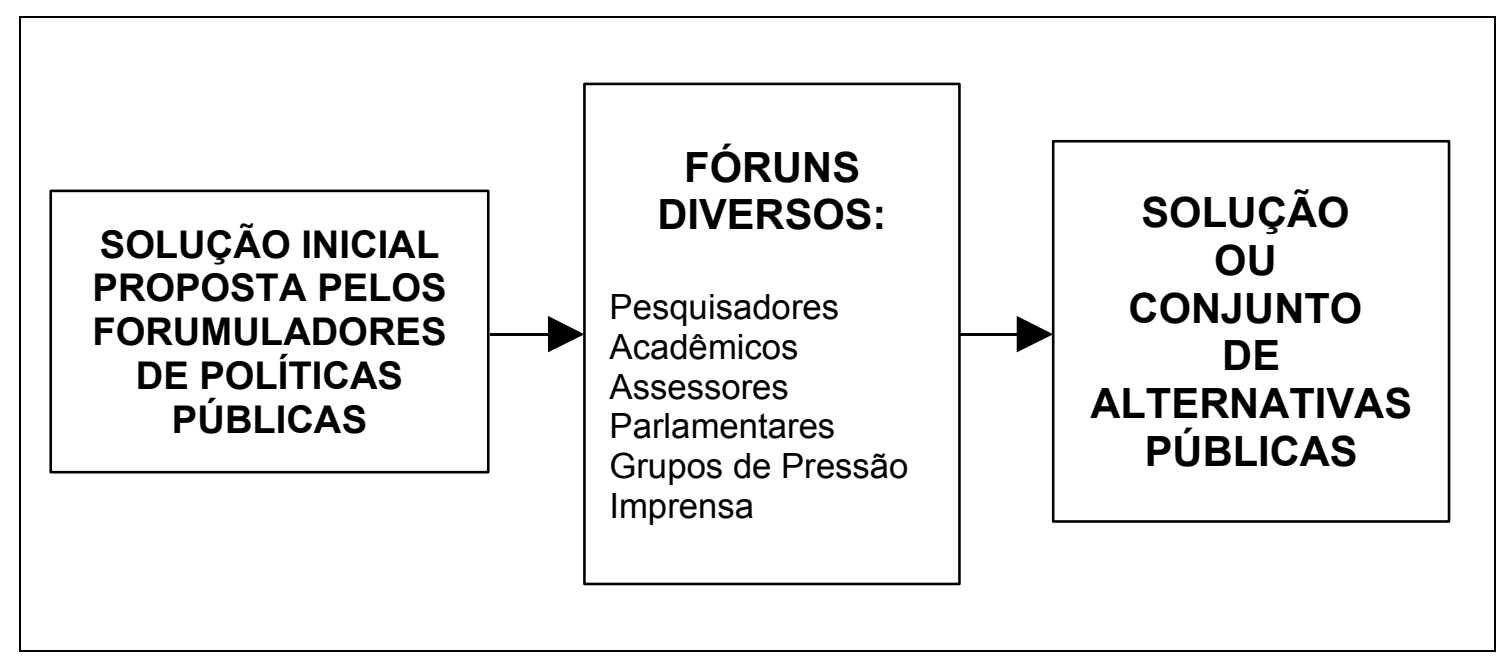

Finalmente, no terceiro fluxo, segundo Kingdon (2003), o consenso ou a adesão a determinada proposta não é construída por meio da persuasão e pelo processo de difusão de idéias como o foi no fluxo anterior que tratou da formatação de solução e de alternativas de políticas públicas. No caso deste terceiro fluxo (fluxo das decisões políticas) o mecanismo utilizado para a construção do consenso ou para a adesão é a negociação política.

Neste fluxo, destacam-se três elementos que exercem influência sobre a agenda do governo: o humor nacional, as forças políticas organizadas, e as mudanças no interior do governo.

O clima político ou humor nacional é caracterizado pela formação de uma atmosfera favorável à germinação de uma idéia. Trata-se de um sentimento "intuitivo" do político no exercício do poder que se forma por meio de conversas formais e informais com assessores, jornalistas, eleitores, ativistas, grupos de interesse, dentre outros, ou ainda por meio de palestras ou viagens.

O clima político também pode ser determinado por pressões do legislativo, pela difusão intensiva de determinada idéia, pelo embate junto a grupos de pressão ou movimentos sociais, ou ainda pelo processo eleitoral.

Se é verdade que o humor nacional cria uma atmosfera favorável à germinação de determinada idéia, também é verdade que o mesmo humor também pode "boicotar" outras tantas idéias. 
As forças políticas organizadas, por sua vez, cumprem o papel de exercer pressão sobre o tomador de decisão política. Estes grupos são lobistas, ativistas, militantes, dentre outros.

Finalmente, as mudanças dentro do governo têm o potencial de desencadear processos que possibilitam ou a inclusão ou a exclusão de determinado item na agenda do governo. As mudanças de governo podem ser gestão decorrente da alternância de poder entre grupos e partidos políticos que disputam eleições; mudanças de equipe; mudanças na composição das Assembléias Legislativas, seja em decorrência de resultados eleitorais seja em decorrência de mudança de posicionamento de partidos políticos ou de legisladores no exercício de seus mandatos; ou ainda mudanças de chefias; mudanças do arcabouço institucional; ou finalmente deslocamento de determinado programa ou política de governo de uma secretaria para outra.

\section{Figura 3}

A tomada de Decisões

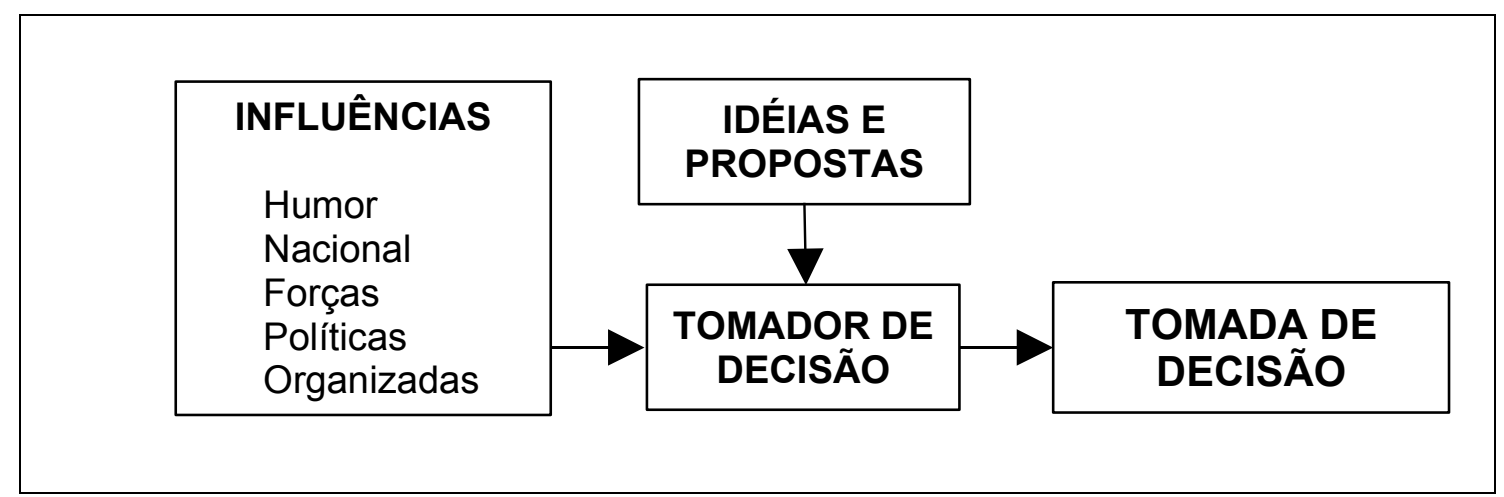

\section{A Janela de Oportunidade e o Empreendedor Político}

A janela de oportunidade é a circunstância na qual os três fluxos (problemas, soluções e alternativas, e decisão política) são reunidos.

A abertura da janela de oportunidade ocorre influenciada ou pelo fluxo dos problemas ou pelo fluxo de decisão política.

Assim, seja por meio da veiculação de determinado indicador, pela ocorrência de alguma tragédia (evento) ou pelo feedback de alguma ação, 
programa ou política de governo; ou ainda quando algum tipo de mudança é introduzida por meio de uma decisão política; então estão dadas as condições para a apresentação de idéias, soluções ou alternativas ao problema aventado.

As idéias, soluções ou alternativas não exercem influência direta sobre a abertura da janela de oportunidade. Apesar disso, podem influenciar a construção de determinado indicador. Os fluxos são independentes, mas não são impermeáveis uns aos outros.

Pode ser também que as referidas idéias, soluções ou alternativas não estejam diretamente relacionadas com o problema em questão e ainda assim pode ser adaptada para, em prática, resolver inteira ou parcialmente o referido problema.

Nesta fase da explicação do modelo, duas questões se fazem necessárias: quem abre a janela? Por quanto tempo a janela permanece aberta?

A janela de oportunidade pode ser aberta ao acaso, quando da ocorrência de uma tragédia (evento), por exemplo, ou quando o empreendedor político toma para si a missão de incluir na pauta do governo um determinado assunto.

Os empreendedores políticos são, de alguma forma, semelhantes aos empreendedores comerciais ou industriais. Para Schumpeter, o empreendedor é alguém que, sem crédito e sem recursos a priori, e, no entanto, com uma idéia inventiva, está disposto a investir seu tempo e a buscar crédito no mercado para colocar sua idéia inventiva em prática. A aposta do empreendedor de Shumpeter é tal, que mesmo sem crédito e sem recurso, está disposto a correr risco, dado que a taxa de retorno do investimento será maior que o risco corrido. O risco, aliás, é de tal ordem grande, que o prazo necessário para a obtenção do retorno do investimento realizado tem que ser menor que o prazo para que a invenção do empreendedor seja modificada, adaptada ou copiada.

Para Kingdon (2003), os empreendedores políticos estão dispostos a investir tempo, energia, reputação e dinheiro numa idéia que lhes dará retorno futuro. O empreendedor político está situado no Poder Executivo, na alta 
burocracia estatal, nos partidos políticos, nas assessorias parlamentares, no próprio parlamento (como parlamentar), na academia, na mídia, ou nos grupos de lobbies.

De acordo com Kingdon (2003), as janelas não permanecem abertas por muito tempo. A janela se fecha, ou seja, a oportunidade se esvai quando pelo menos um dos fluxos de desarticula dos demais.

A oportunidade de mudança pode se esvair quando, por exemplo, um governo recém eleito forma sua equipe realiza a transição entre a eleição e a posse e neste ínterim não se consegue apresentar uma situação na forma de problema, ou ainda, quando apesar da apresentação do problema, não há uma solução articulada pronta para ser posta em prática.

Para os propósitos deste trabalho, o que se buscará entender, a partir das propostas e dos conceitos desenvolvidos por Kingdon, é quem e como apresenta, articula e desenvolve o tema da cooperação regional ou intermunicipal na agenda dos governos locais em determinada região.

\section{Conclusão}

O esforço teórico proposto aqui é para lastrear a pesquisa empírica. Não se trata de adotar uma teoria ou outra. Trata-se de, inicialmente localizar este trabalho diante dos grandes campos de conhecimento. Deste modo o esforço feito auxiliou a localizar este trabalho no campo de conhecimento da ciência política.

Em seguida, dada a ampla disseminação dos enfoques neoinstitucionalistas, busquei identificar suas principais características e relacionálas com estudos específicos relacionados com os Consórcios Intermunicipais no Brasil, em um esforço de compreender em cada um desses trabalhos qual era a importância dos atores envolvidos com o processo de formação dos consórcios intermunicipais e como as instituições influenciavam o comportamento dos referidos atores.

Assim, identificamos apenas estudos que se apóiam nos conceitos desenvolvidos pelo Neo-Institucionalismo da Escolha Racional. 
Além disso, encontramos um conjunto de elementos nas diferentes abordagens do neo-institucionalismo capazes de auxiliar na análise dos casos sobre formção de consórcios intermunicipais.

A abordagem neo-institucionalista em suas três vertentes auxilia, como pano de fundo, a ler e compreender os complexos fenômenos sociais observados, mas ainda restava encontrar um arcabouço teórico que auxiliasse a estruturar um olhar sobre o trabalho empírico a ser desenvolvido.

Então, para compreender, no trabalho empírico, como o processo de formação dos consórcios se desenvolvia em diferentes dimensões - a dimensão da política propriamente dita e a dimensão da política pública busquei utilizar elementos e conceitos desenvolvidos por John Kingdon (2003).

Este autor, do meu ponto de vista, ao analisar o processo de formação de agendas consegue distinguir processos distintos, discutindo-os separadamente, mas interrelacionando-os ao longo do percurso de concepção de decisão de implementação de determinada política pública ${ }^{15}$.

Este capítulo então buscou apresentar e discutir o arcabouço teórico que iluminará o olhar e análise e a interpretação dos casos empíricos sobre a constituição dos consórcios no Brasil a partir dos anos 90 .

\footnotetext{
${ }^{15}$ Como Kingdon (2003) adota como casos estudados a formação da agenda do Governo Federal americano (Presidência dos Estados Unidos) em dois setores específicos (transporte e saúde), o complexo modelo por ele construído será uma referência usada, neste trabalho, sempre com muito cuidado e com o olhar atento, de que nossas instituições são muito diferentes das instituições americanas.
} 


\section{Capítulo 2:}

\section{Uma visão Panorâmica dos Consórcios Intermunicipais no Brasil}

\section{Introdução}

Os Consórcios Intermunicipais são organizações capazes de articular políticas públicas setoriais com políticas territoriais; possibilitam, portanto, a territorialização de políticas públicas setoriais, ou seja, de políticas públicas vinculadas a setores como saúde, saneamento, dentre outras.

Os Consórcios Intermunicipais surgem da iniciativa autônoma dos municípios, que resolvem atuar de forma cooperada em torno de uma questão comum. A sua criação pode ser conseqüência da vontade própria do município, pode ser induzida por um ator externo de mesmo patamar (por exemplo, um município vizinho) ou por um ator externo de patamar distinto (por exemplo, governo federal ou governo estadual).

A proposta de análise dos Consórcios intermunicipais nos moldes deste trabalho está circunscrita ao período que se estende de 1988 até 2005, ano em que foi promulgada e publicada a Lei 11.107/2005, que especifica e regulamenta a prática do consorciamento entre municípios. Apesar do limite temporal da análise, buscar-se-á, neste trabalho, resgatar a instituição dos primeiros consórcios em São Paulo surgidos a partir de 1982. Resgatar o surgimento dos Consórcios Intermunicipais em São Paulo nos anos 80 se justifica por dois motivos: pelo aspecto inovador do período e pelo fato de que vários consórcios criados ao longo dos anos 90 têm como fonte de inspiração algum consórcio criado em São Paulo no período imediatamente anterior a 1988.

Este capítulo tem o objetivo de organizar e sistematizar as experiências de consórcios intermunicipais surgidas no Brasil desde meados dos anos 80 para melhor situar o objeto analítico deste trabalho.

Parte-se da idéia de que apesar do longo tempo de existência dos consórcios, esta forma de cooperação entre municípios ainda não faz parte da agenda do governo nacional. Entretanto, a variedade e o grande número de municípios que participam de algum tipo de consórcio intermunicipal indicam 
que o referido tema entrou, em momentos diferentes, nas agendas de diversos governos locais.

Diante do fato dos Consórcios Intermunicipais não terem entrado na agenda do governo nacional ainda que tenham conseguido avanços significativos em termos de alterações legais tanto constitucionais quanto infraconstitucionais; e do fato de ter entrado em muitas agendas de governos locais, mesmo com a fragilidade do ponto de vista do aparato legal e institucional. Este capítulo buscará apresentar um balanço histórico da formação dos consórcios no Brasil.

Em última instância, este capítulo buscará responder às seguintes questões:

O que são os consórcios intermunicipais, onde estão localizados e em torno de quais temas foram organizados?

Em quais bases de dados foram encontradas as experiências expostas neste capítulo? A partir das bases de dados consultadas, quais são as experiências de Consórcios Intermunicipais mais emblemáticas?

Finalmente, qual a trajetória traçada pela idéia e pela prática dos Consórcios Intermunicipais no território brasileiro?

Para responder as questões enunciadas acima e melhor localizar o tema dos consórcios intermunicipais na prática dos governos locais brasileiros nos últimos anos, este capítulo foi estruturado em seis seções, além desta introdução e das conclusões:

- Uma Definição de Consórcios Intermunicipais;

- A Atualidade temática dos Consórcios Intermunicipais;

- Considerações sobre as Bases de Dados utilizadas;

- Antecedentes no Estado de São Paulo: os Consórcios anteriores aos anos 90;

- Os Consórcios no Brasil Recente;

- Os Consórcios Intermunicipais teriam entrado na Agenda Nacional? 


\section{Uma Definição de Consórcio Intermunicipal}

Nesta seção, busco uma definição de consórcio. Definição, segundo Mill (1974), é "uma proposição declarativa da significação de uma palavra, isto é, a significação que a palavra tem na acepção comum ou a significação que aquele que fala ou escreve pretende incorporar-lhe para os objetivos específicos de seu discurso" (Mill, 1974: 148). O que é consórcio? Para responder a esta questão, percorrerei três caminhos: o primeiro, buscando a origem etimológica da palavra consórcio; o segundo, apresentando o sentido comum da palavra, em sua acepção mais geral; e finalmente, o terceiro, apresentando definições de consórcios intermunicipais rastreadas na literatura recente sobre $o$ assunto.

Em termos etimológicos, consórcio, do latim consortiu, implica a idéia de associação. No sentido comum, consórcio também designa associação. No âmbito privado, consórcio está diretamente relacionado com associação de pessoas para aquisição de um bem material. Ao longo dos anos 90 , foi comum a associação de pessoas para aquisição de algum tipo de bem de consumo durável como automóvel ou motocicleta, por exemplo. Um grupo de 10 pessoas se associava em "consórcio" e cada uma das pessoas pagava durante 10 meses 10 prestações referentes ao automóvel ou à motocicleta. A cada mês um automóvel ou uma motocicleta era sorteado para cada participante, que independentemente do sorteio continuava pagando sua prestação.

Nesta medida, "consórcio" era uma associação entre pessoas que se uniam em torno de um interesse comum. Ainda que estas pessoas não se conhecessem e não confiassem umas nas outras, o aumento de confiança e a redução do risco (da associação) decorria da existência de um contrato e de um mediador externo ao grupo.

No caso dos consórcios intermunicipais, destaco quatro definições. A primeira definição, cunhada por Spink (2006), os consórcios são apresentados em oposição às regiões metropolitanas; a segunda, cunhada por Vaz (1997), consórcios são apresentados como organizações; depois, a definição de 
Moreira (2001), que busca definir e diferenciar consórcio de convênios (forma vertical de cooperação); e finalmente, na quarta definição, cunhada por Cruz (2002), os consórcios são apresentados como forma de cooperação horizontal.

Spink (2006) define consórcio em oposição às regiões metropolitanas:

"se as Regiões Metropolitanas começaram como um esforço
institucional de cima para baixo caracterizado por uma
associação forçada entre seus entes, os consórcios
municipais tiveram como base uma relação horizontal, ou
mesmo uma relação de baixo para cima, caracterizada por
uma arranjo organizacional baseada na associação
voluntária dos entes participantes".

De forma sintética, para Spink (2006) "o consórcio municipal é simplesmente um acordo para cooperação em torno de uma questão comum".

Vaz (1997), por sua vez, define consórcio como "entidade que reúne diversos municípios para a realização de ações conjuntas que se fossem produzidas pelos municípios, individualmente, não atingiriam os mesmos resultados ou utilizariam um volume maior de recursos". Em seguida, Vaz (1997) ressalta os aspectos organizacionais dos consórcios tratando de sua personalidade jurídica (normalmente assume a figura de sociedade civil sem fins lucrativos) e de sua autonomia financeira.

Moreira (2001), por sua vez, afirma que consórcio é uma "associação de municípios, criada para a execução de atividades e/ou serviços públicos de interesse comum dos partícipes" e conclui que, "diferentemente dos convênios, os consórcios são acordos celebrados entre pessoas públicas do mesmo nível de governo".

Finalmente, Cruz (2002) afirma que consórcios são "acordos firmados entre entidades estatais, autárquicas, fundacionais ou paraestatais, sempre da mesma espécie, para realização de objetivos de interesse comum dos partícipes, mediante a utilização de recursos materiais e humanos que cada um dispõe".

Dos caminhos percorridos, apreende-se que consórcio é uma associação originada de algum tipo de interesse comum e voltada para resolver 
um problema comum dos entes pertencentes ao mesmo nível de governo (município-município).

As definições apresentadas enquadram os consórcios num debate sobre cooperação. Moreira (2001), por exemplo, apresenta e diferencia duas formas de cooperação: os convênios (cooperação vertical) e consórcios (cooperação horizontal). Spink (2006), por sua vez, apresenta consórcios e Regiões Metropolitanas como duas formas distintas de cooperação horizontal, e as distingue através do ator que propõe a iniciativa: as Regiões Metropolitanas são propostas por um ente de outra esfera de governo (Estado) externo aos entes que comporão a associação; os consórcios, por sua vez, são propostos por um dos entes participantes da associação.

A definição de Vaz, por sua vez, apresenta o consórcio como associação estruturada em torno de uma organização. Nesta medida, consórcio não é um Protocolo de Intenções e tampouco um Convênio, mas uma organização.

Neste aspecto, importante diferenciação entre instituições e organizações é realizada por North (2001:15), segundo a qual as instituições constituem-se em regras do jogo e as organizações são jogadores. Para este representante do Neo-institucionalismo Histórico "o propósito das regras é definir a forma em que o jogo ocorrerá. Mas o objetivo da equipe dentro do conjunto de regras é ganhar o jogo através de uma combinação de atitudes, estratégia e coordenação".

O pressuposto para o surgimento de consórcios de acordo com as definições aqui apresentadas é a existência de interesse comum entre os participantes.

Interesse, no entanto, não é suficiente para levar a cabo uma ação coletiva. É preciso que haja confiança. Assim, pergunta-se: é possível construir confiança? Como se constrói confiança? As organizações auxiliam na construção de confiança?

Os neo-institucionalistas têm respostas diferentes para cada uma dessas questões. Para os neo-institucionalistas da escolha racional, a ação coletiva pode ser induzida independentemente de confiança prévia, por meio da construção de mecanismos de incentivos e punições. Para estes, as 
organizações são importantes, não para gerar confiança, mas para reduzir o risco e para induzir a ação coletiva.

Para os neo-institucionalistas sociológicos, a carga cultural e as tradições locais configuram a ação dos indivíduos diante de novas instituições. Neste aspecto, os laços culturais garantem, a priori, relações de confiança necessárias para o bom desempenho institucional.

Para os estudiosos do capital social como Putnam (1996), por exemplo, a confiança traduzida como capital social é condição necessária para levar a cabo algum tipo de ação coletiva (como os consórcios). Para Locke (2003), outro autor que utiliza o conceito de capital social, pelo contrário, a confiança pode ser construída por meio de uma organização.

Para os neo-institucionalistas históricos, finalmente, o entendimento do processo de construção de relações de confiança é resultado de uma mescla que inclui o enfoque do cálculo estratégico dos atores racionais envolvidos no jogo da política com um enfoque cultural, privilegiado pelo institucionalismo sociológico.

Para efeitos deste trabalho, Consórcios Intermunicipais são organizações resultantes da disposição de cooperação dos atores políticos relevantes de diversos municípios (prefeitos) que decidem cooperar entre si para resolver problemas relativos a um tema ou a um setor específico.

Ao longo deste trabalho, buscaremos verificar, por meio de uma vasta pesquisa empírica, os processos políticos que levam à constituição dos consórcios, bem como o papel dos diversos atores, dos laços de confiança previamente existentes, e da circulação das pessoas e das idéias entre as diversas arenas sobre as quais se desenrolam o jogo político.

\section{A Atualidade Temática dos Consórcios Intermunicipais}

Nesta seção trato da atualidade do tema Consórcios Intermunicipais, espécie de justificativa para o trabalho, para indicar a pertinência do estudo.

A atualidade do tema se verifica por meio da emergência de reportagens e pelo aumento de artigos veiculados na grande imprensa, pela organização de 
bancos de dados com relatos e informações sobre as experiências de consórcios municipais recentes, e pelas alterações acontecidas na legislação que regulamenta o assunto na prática.

Em termos de artigos veiculados na grande imprensa, destaca-se que em 23 de setembro de 1995, Márcio Moreira Alves descreveu no jornal O Globo, a experiência de um Consórcio de Saúde de 11 municípios do Alto São Francisco (MG). Segundo o autor, o Consórcio de Saúde é "uma idéia excelente, capaz de melhorar imensamente a sorte dos brasileiros".

Em 17 de janeiro de 1998, o mesmo Márcio Moreira Alves descreveu, $\mathrm{n}$ 'O Globo, a primeira experiência brasileira de consórcio interestadual, também na área da saúde. Trata-se de uma experiência ocorrida em Nanuque (MG), com os municípios da Bahia e do Espírito Santo.

Finalmente, em 1999, Marcio Moreira Alves volta a tratar dos consórcios intermunicipais, agora na área de produção e abastecimento. Trata-se do Consórcio Intermunicipal de Produção e Abastecimento de São Luís (MA) por meio do qual 14 municípios resolveram agir juntos para "aumentar a produtividade e agregar valor ao que já fazem". Segundo o próprio autor, do "primeiro consórcio de produção do país".

Os três artigos de Márcio Moreira Alves são evidências de contraponto à propagada idéia de jogos competitivos entre municípios e entre Estados, por meio principalmente da Guerra Fiscal.

Em 19 de maio de 2001, José Eli da Veiga publicou artigo no jornal O Estado de São Paulo chamado "Articulações Intermunicipais", descrevendo a organização dos municípios de Santa Catarina em 21 microregiões para reivindicar construção de estrada, expansão da rede elétrica, e depois para alcançar formas de desenvolvimento econômico.

Segundo análise do autor:

"em movimento independente das demarcações adotadas pelo governo estadual (Microrregiões Polarizadas e Bacias Hidrográficas), e pelo IBGE (Microrregiões e Mesorregiões Geográficas), os municípios catarinenses se organizaram em 21 microrregiões "espontâneas", conhecidas como 
regiões das associações, cada uma com seu respectivo centro regional, também chamado de "município-pólo".

Em 13 de março de 2002, Ricardo Abramovay publicou artigo no jornal Gazeta Mercantil denunciando a pouca relevância do papel dos territórios no processo de desenvolvimento e apresentando a emergência do caso francês.

Segundo o autor, a França criou recentemente novas entidades geográficas (os "pays"), instância onde os políticos, os atores econômicos e sociais se coordenam para levar adiante projetos de desenvolvimento comuns a uma área onde vivem entre 15 mil e 450 mil habitantes.

Para o autor, no caso brasileiro, "os pequenos municípios são importantes na fiscalização dos recursos, mas não podem ser tomados como instância de planejamento dos potenciais produtivos de uma determinada região".

A conclusão é a de que "entre o Estado da Federação e o município, há um vazio organizacional que motiva seguramente a perda de oportunidades promissoras de geração de renda".

Tanto Veiga (2001) quanto Abramovay (2002) trata da organização do território articulada com desenvolvimento econômico. Não tratam especificamente dos consórcios, seguramente uma espécie como os "pays", no gênero organização territorial.

De qualquer modo, tanto um quanto outro evidencia experiências de cooperação horizontal.

Quanto às reportagens, destaca-se uma publicada recentemente pelo jornal Valor Econômico (14/04/2005), chamada "Pequenas cidades formam consórcios", segundo a qual:

\footnotetext{
"a formação de consórcios intermunicipais para realização de ações conjuntas em áreas como saúde, meio ambiente e educação se tornou alternativa viável para municípios de pequeno porte e, principalmente, para aqueles que atingiram o limite de endividamento previsto na Lei de Responsabilidade Fiscal"16.
}

\footnotetext{
${ }^{16}$ De acordo com a Lei de Responsabilidade Fiscal, o limite de endividamento dos municípios não pode ser superior a 1,2 o valor da Receita Corrente Líquida.
} 
Também merece destaque a reportagem publicada n'O Estado de São Paulo (03/05/2005) chamada "Um projeto para gerir a metrópole", segundo a qual, apesar das proporções nacionais, os 39 municípios da Região Metropolitana de São Paulo são administrados como se fossem partes isoladas de um todo. Esses municípios "são cruzados e inundados pelos mesmos rios, abastecidos pelas mesmas represas, com ruas que começam em uma cidade e acabam em outras, mas seus prefeitos conversam pouco entre si".

Enquanto os artigos de Alves $(1995 ; 1998)$ indicam a emergência dos consórcios de saúde, inicialmente entre municípios e depois entre Estados; os artigos de Veiga (2001) e Abramovay (2002) indicam a necessidade da organização territorial em prol do desenvolvimento econômico regional; e as reportagens mais recentes de dois expressivos jornais de circulação nacional apontam os consórcios como importantes ferramentas de gestão tanto para municípios pequenos (Valor Econômico, 14/04/2005), quanto para municípios metropolitanos (OESP, 03/05/2005).

Depreende-se destes artigos e reportagens, que a emergência do tema "consórcios municipais" estão diretamente relacionados a problemas de políticas públicas efetivos no território nacional: articular políticas verticalmente; criar formas de cooperação horizontais; valorizar o território em termos de sua funcionalidade e não em termos burocráticos apenas ${ }^{17}$.

Além da emergência de reportagens e artigos veiculados na grande imprensa, há uma recente constituição de bancos de dados com relatos e informações sobre as experiências de consórcios municipais recentes. Dentre os bancos de dados e registro de experiências, destacam-se:

- Fundação Instituto Brasileiro de Geografia e Estatística (IBGE);

- Programa Gestão Pública e Cidadania (PGPC/FGV/EAESP);

- Instituto Pólis;

\footnotetext{
17

Em diversos artigos publicados no jornal Valor Econômico, Eli da Veiga chama atenção para o fato do Brasil, em termos legais e estatísticos se constituir como um país urbano. No entanto, o autor verifica que poucos municípios cumprem funções de "pólos" em torno de aglomerados urbanos e que a maior parte dos municípios tem características mais rurais. Daí o autor, trata da necessidade de romper a dicotomia urbano-rural; reconhecer a interdependência dos municípios; criar mecanismos institucionais para favorecer o desenvolvimento econômico das regiões, e não de forma pulverizada, dos municípios individualmente. Neste aspecto, os consórcios constituem-se em mecanismo institucional e organizacional importante.
} 
- Centro de Estudos e Pesquisas em Administração Municipal.

Além da imprensa e dos bancos de dados, algumas alterações constitucionais e infraconstitucionais relacionadas à regulamentação dos consórcios públicos intermunicipais indicam a relevância do tema, dentre as quais a Emenda Constitucional 19 (EC-19/98) e a Lei 11.107 de 06 de abril de 2005.

Apesar da baixa regulamentação constitucional até meados de 2005, as bases de dados, os artigos, reportagens e trabalhos mais analíticos indicavam que, ainda assim, ao longo dos anos 90, a articulação setorial dos municípios em torno de "consórcios intermunicipais" nas áreas de saúde, recursos hídricos, abastecimento alimentar, desenvolvimento econômicos, dentre outros, representou um aspecto inovador nas políticas públicas desenvolvidas no âmbito "intermunicipal".

\section{Considerações sobre as Bases de Dados utilizadas}

Esta seção busca responder às seguintes questões: Em quais bases de dados há informações sobre os Consórcios Intermunicipais? Quais os critérios para a escolha de determinadas bases de dados em detrimento de outras?

Do ponto de vista quantitativo, a primeira fonte de informação consultada foi o Instituto Brasileiro de Geografia e Estatística (IBGE). Foram encontradas três bases de dados que permitiam verificar o perfil dos municípios que participam de algum tipo de consórcio. No entanto, há pelo menos duas limitações provenientes das bases de dados analisadas:

- Não é possível comparar os Consórcios Municipais entre si, visto que os dados disponíveis usam como unidade de análise o município e não o consórcio;

- A comparação entre as três bases de dados é prejudicada porque em cada uma delas há um grupo diferente de "setores" sobre os quais os municípios se consorciam. 
As três bases de dados encontradas são frutos das Pesquisas de Informações Básicas Municipais, realizadas, respectivamente, em 2001, 2003, e entre o final de 2005 e o começo de 2006.

As pesquisas foram publicadas, respectivamente, em 2001, 2004 e 2006. As informações foram coletadas, sempre que possível, por meio de entrevistas presenciais.

As pesquisas trataram do Perfil da Gestão Pública dos Municípios brasileiros, respectivamente, em 2000, 2002 e em 2005, e tiveram como objetivo colher informações junto às prefeituras de todos os municípios do Brasil, ou seja, 5.560 municípios instalados até 31 de dezembro de 2001 para as duas primeiras pesquisas, e 5.564 municípios instalados até 31 de dezembro de 2005.

$\mathrm{Na}$ primeira pesquisa, o IBGE organizou os municípios segunda a existência de Consórcios Intermunicipais em 14 setores: educação, saúde, habitação, aquisição e/ou uso de máquinas e equipamentos, serviços de abastecimento de água, serviços de esgotamento sanitário, limpeza urbana, coleta de lixo, coleta seletiva de lixo, reciclagem de lixo, remoção de entulhos, coleta de lixo especial, tratamento ou disposição final de lixo, e processamento de dados.

Na segunda pesquisa, o IBGE tratou a cooperação entre municípios sob o título de "Articulações intermunicipais nos municípios", e classificou as formas de articulação em 12 setores e cinco categorias.

Os setores foram Educação, Saúde, Assistência e Desenvolvimento Sociais, Direito de Crianças e Adolescentes, Emprego/Trabalho, Turismo, Cultura, Habitação, Meio Ambiente, Transporte, Desenvolvimento Urbano e Desenvolvimento Econômico.

As categorias, por sua vez, foram as seguintes: Consórcios Intermunicipais, convênios de cooperação com entidades públicas, convênios de parceria com empresas privadas, ações integradas com outros municípios e apoio de entidades privadas ou da comunidade.

Finalmente, na terceira pesquisa, o IBGE tratou a cooperação entre municípios sob o título de "Articulações interinstitucionais entre os entes federativos", e classificou as formas de articulação nas mesmas 12 da pesquisa 
anterior, trocando somente Desenvolvimento Econômico por Saneamento e/ou Manejo de Resíduos Sólidos.

As categorias usadas nesta segunda pesquisa foram diferentes da primeira: os Consórcios foram desdobrados em Consórcios públicos intermunicipais, com os estados e com a União; convênios de parceria com o setor privado; e apoio do setor privado ou de comunidades.

Mesmo comprometendo parcialmente as possibilidades de comparação entre as pesquisas, deve-se esclarecer que para a terceira pesquisa o fez para adaptar-se à Lei 11.107, de 06 de abril de 2005, que regulamenta os Consórcios intermunicipais.

Para fins deste trabalho, de apresentar uma visão panorâmica dos Consórcios Intermunicipais existentes no país, serão utilizadas apenas as informações da pesquisa Perfil da Gestão Pública dos Municípios brasileiros publicada em 2001.

Do ponto de vista mais qualitativo, foi realizada uma primeira busca na Rede de Banco de Dados de Gestão Local, que integra um conjunto considerável de bancos de dados sobre gestão local. Os referidos bancos de dados são organizados por diferentes organizações sociais, desde organizações universitárias, como o banco de dados do Programa Gestão Pública e Cidadania da Fundação Getúlio Vargas da Escola de Administração de Empresas de São Paulo (PGPC-FGV-EAESP); de organizações da sociedade civil, como o Boletins Dicas do Instituto Polis; de organizações governamentais, como é o caso da Rede de Comunicação de Experiências Municipais (RECEM) da Fundação Prefeito Faria Lima - CEPAM, órgão vinculado ao governo do Estado de São Paulo; e mesmo de indivíduos que estudam a "gestão local", como é o caso do Professor Ladislau Dowbor, da Pontifícia Universidade Católica de São Paulo (PUC-SP).

As bases consultadas foram justamente estas enunciadas acima, por três motivos:

- São as bases de dados que consideram a existência de Consórcios. Bases de dados como os da Fundação ABRINC, por exemplo, apesar de sua importância para temas relacionados a educação e a 
garantia dos direitos das crianças, não permitem a verificação de experiências de municípios por meio de consórcios intermunicipais.

- São bases de dados organizadas por instituições de origens diversas: uma universitária (PGPC-FGV-EAESP); uma organização não governamental (Boletim Dicas - Instituto Polis); e uma base de dados histórica, a primeira base de dados que buscou organizar e sistematizar experiências de "gestão local", de origem governamental (RECEM-FPFL-CEPAM).

- São bases de dados que, metodologicamente, estão vinculadas à idéia de "disseminar inovações" em detrimento da idéia de "melhores práticas" (best pratices).

Na Rede de Banco de Dados de Gestão Local há uma infinidade de bancos nacionais e internacionais. Mattos (2004) apresenta detalhadamente 0 histórico de cinco bancos de dados da Rede de Gestão Local: RECEM; DICAS; PGPC; Prefeito Amigo da Criança; CAIXA-Melhores Práticas.

Para cada um desses bancos de dados, Mattos (2004) também apresenta seus vínculos institucionais, critérios de seleção das experiências, objetivos e estratégias de disseminação.

Apesar deste trabalho não ter como preocupação central o detalhamento das bases de dados nas quais foram encontradas as experiências de Consórcios Intermunicipais, um aspecto relacionado às vinculações institucionais de cada uma das Bases de Dados utilizadas neste trabalho, e um aspecto conceitual concernente à idéia de disseminação de experiências são relevantes e merecem destaque. Ambos aspectos estão diretamente relacionados um com outro.

Quanto às vinculações institucionais ressalta-se que há uma intensa troca de informações e debates entre as três bases de dados utilizadas neste trabalho.

Estão vinculadas à Rede de Comunicação de Experiências Municipais (RECEM) da Fundação Prefeito Faria Lima - CEPAM, a Caixa Econômica Federal (CEF), o Banco de Êxitos (Colômbia), o Instituto Polis, o Instituto de Pesquisas Tecnológicas (IPT) e o Programa Gestão Pública e Cidadania da 
Fundação Getúlio Vargas da Escola de Administração de Empresas de São Paulo (PGPC-FGV-EAESP).

Ao Boletim Dicas do Instituto Polis, por sua vez, estão vinculados, dentre outros, a Secretaria Nacional de Assuntos Institucionais do Partido dos Trabalhadores (SNAI-PT), a Fundação Friedrich Ebert (Alemanha), UNICEF e BNDES.

Finalmente, ao Programa Gestão Pública e Cidadania estão vinculados, dentre outras instituições, a Fundação Ford, o BNDES, o CEPAM e o Polis.

A correlação e interação entre as instituições responsáveis pelas bases de dados utilizadas neste trabalho indicam, ao mesmo tempo, uma proximidade conceitual das instituições, e a adoção conceitual neste trabalho do que se denomina disseminação de experiências de governos locais em detrimento do que se convencionou chamar de "melhores práticas" (best pratices).

Segundo Spink (2003):

\begin{abstract}
"distingue-se a idéia de compartilhar e disseminar inovações e experiências que tenham algum êxito, e a idéia de "melhores práticas", apresentadas como soluções a ser seguidas porque são corretas e aprovadas, perspectiva que deixaria de lado o debate e a discussão sobre por que, como, em que circunstâncias e quais os elementos-chave do processo".
\end{abstract}

Esta perspectiva apresentada acima por Spink (2003) orientou a escolha das bases de dados utilizadas nas seções seguintes ${ }^{18}$.

\title{
Antecedentes no Estado de SP: Os Consórcios anteriores aos anos 90
}

Para realização desta seção foram analisados principalmente os Boletins do Interior produzidos entre os anos de 1982 e 1986 pelo CEPAM. Antes deste

\footnotetext{
18 Além dos referidos Bancos de Dados, também foi consultado o Banco de Dados da Presidência da República, por sua vez, contempla 26 experiências, sendo a maior parte delas representativa das regiões Sul e Sudeste (23 experiências). As exceções ficam por conta do Consórcio Intermunicipal de Produção e Abastecimento de São Luís do Maranhão (MA), do Consórcio Intermunicipal do Vale do Jiquiriçá (BA), e do Consórcio Intermunicipal para o Desenvolvimento Integrado das Bacias dos Rios Miranda e Apa (MS). Em termos setoriais, o referido Banco de Dados contém dez Consórcios de saúde, oito Consórcios de meio ambiente, recursos hídricos e saneamento, seis Consórcios de Desenvolvimento Regional e dois Consórcios de Informática.
} 
período, os Boletins tinham interesse muito mais tecnicista, legalista e burocrático, no sentido de orientar os prefeitos com relação à legislação. A partir de 1983, ou seja, a partir do início do Governo Montoro, os Boletins do Interior, além da preocupação em orientar os prefeitos, também passou a ser em registrar experiências locais.

O interesse em registrar as experiências já constituía, por si só, um estímulo à criatividade dos gestores públicos locais, uma vez que o registro Ihes dava visibilidade.

Neste período, entre 1983 e 1986, os referidos Boletins destacavam o surgimento e o desenvolvimento dos Consórcios Intermunicipais, o que demonstra a importância do tema para o governo estadual daquele período.

O Boletim do Interior produzido neste período, aliás, constituiu-se em um precursor da Rede de Comunicação de Experiências Municipais (RECEM).

Em 1982, o governo Montoro democraticamente eleito assumiu como compromisso de governo a criação de instrumentos para estimular a participação popular e a descentralização das políticas públicas.

No período que se estende de 1983 a 1986, durante o governo Montoro, os consórcios surgiram nas mais diversas áreas, desde processamento de dados ou produção e distribuição de alimentos, até fabricação de artefatos de cimento e de placas de sinalização, proteção da fauna e flora, exploração de pedreiras, passando por recuperação de estradas vicinais ou criação de uma central de medicamentos ${ }^{19}$.

O governo estimulou amplamente a formação de consórcio visando à produção de alimentos para a merenda escolar, hospitais, entidades assistenciais, e auto-consumo. A partir desse estímulo, multiplicaram-se pelas cidades do interior as "vacas mecânicas" (que produzem leite de soja), as padarias comunitárias municipais, os projetos de apicultura, cunicultura e piscicultura.

\footnotetext{
${ }^{19}$ Esta parte está concentrada na experiência do Estado de São Paulo no período de 19821986 por dois motivos: primeiro, pelo compromisso explicito e sua efetivação do governo Montoro com a descentralização e a criação de instrumentos para sua consolidação, dentre as quais os consórcios intermunicipais; segundo, porque vários consórcios surgidos nesta época foram fontes de inspiração para outros consórcios.
} 
Paralelamente aos compromissos do governo do Estado de se criar mecanismos de cooperação horizontal (municípios entre si), foi realizado, em 1984, o $27^{\circ}$ Congresso Estadual dos Municípios, intensificando a iniciativa de se criar consórcios. A justificativa para a criação de Consórcios Intermunicipais era de que somando esforços e recursos, os municípios poderiam juntos vencer dificuldades comuns.

Como a legislação vigente naquela época (1983-1986) não especificava a forma pela qual os consórcios seriam constituídos, foi proposto pelo governo Montoro que os Consórcios seriam "associações civis de municípios, dotadas de personalidade de direito privado". No contexto de um regime político altamente centralizador, a medida foi proposta com vistas a criar agilidade para alcançar soluções de problemas locais de maneira simples e desburocratizada.

De acordo com Montoro e Figueiredo (1987), os consórcios intermunicipais obedeceriam a estrutura mínima prevista na Lei Orgânica dos Municípios, compondo-se de três órgãos - Conselho de Prefeitos, Conselho Fiscal e Secretaria Executiva - com as seguintes composições e atribuições:

Conselho de Prefeitos: órgão máximo de deliberação, responsável pela política de atuação, é formado pelos prefeitos dos municípios participantes. Tem um presidente e um vice-presidente, ambos escolhidos no âmbito do próprio Conselho de Prefeitos.

Conselho Fiscal: cada município, por meio da Câmara Municipal, indica um representante para compor o Conselho Fiscal. O representante não pode ser funcionário público ou vereador. O Conselho Fiscal tem a função de acompanhar a gestão e fiscalizar as finanças e a contabilidade relacionada ao Consórcio.

Secretaria Executiva: trata-se da estrutura operacional necessária para a realização do planejamento e da execução das ações e atividades do Consórcio. A Secretaria Executiva pode constituir-se de uma única pessoa, ou de várias diretorias e funcionários. A decisão sobre o desenho da referida Secretaria depende da decisão do Conselho de Prefeitos.

Naquele período, os consórcios tinham "a possibilidade de desenvolver mais de um tipo de atividade, embora englobando maior ou menor número de 
municípios. Por exemplo: dez Prefeituras unem-se para administrar um hospital regional, enquanto cinco delas montam também uma central de medicamentos. A contribuição de cada Prefeitura ao consórcio não precisa ser necessariamente igual, podendo obedecer a critérios como população, receita própria, orçamento, uso de bens, etc. Caso seja conveniente, os custos podem ser divididos entre fixos e variáveis, mas, de qualquer forma, os Consórcios Intermunicipais seguem as normas contáveis das empresas privadas, preservando-se apenas os princípios licitatórios, por serem compostos por pessoas de direito público". A iniciativa da constituição dos consórcios geralmente partia dos prefeitos e contava com o apoio do governo do Estado. Em quatro de fevereiro de 1986, o governo do Estado de São Paulo incluiu a assistência técnica e financeira aos consórcios intermunicipais como função da Secretaria do Interior.

É interessante notar que embora os consórcios de saúde tenham aparecido com maior intensidade a partir dos anos 90 em vários Estados, mas principalmente no Estado de Minas Gerais; em 1983, por reivindicação dos prefeitos da região de São João da Boa Vista o governo do Estado de São Paulo em parceria com a Faculdade de Medicina da Unicamp auxilia na constituição de um consórcio de saúde para a transformação de um pequeno hospital estadual em hospital regional. Nesta região, aliás, surgiu outro Consórcio, desta vez, de informática, integrando 16 prefeituras. Por meio do Consórcio Intermunicipal de Informática, foram adquiridos dois computadores com impressora para possibilitar ganhos de escala aos municípios vizinhos que realizavam tarefas corriqueiras e semelhantes entre si.

Outro exemplo foi o Consórcio de Desenvolvimento da Região de Sorocaba, envolvendo 15 municípios para produzir e distribuir merenda escolar. Para melhorar ainda mais seu desempenho, esse consórcio firmou convênio com o Ministério da Agricultura (em 25 de maio de 1986) para possibilitar o cultivo de arroz, feijão, milho, batata e outros. Outro consórcio deste período foi o de Pavimentação em São José do Rio Preto abrangendo 19 municípios 
Ao todo foram implementados, em São Paulo, no referido período, 34 Consórcios Intermunicipais, 14 deles envolvendo 106 municípios que desenvolveram atividades ligadas à chamada "Batalha da Alimentação".

A formação de consórcios, no caso de São Paulo, no período 1983-1986 se explica, de imediato, pela indução do governo do Estado.

A indução externa ao território é perceptível, dado que havia uma Secretaria do Interior e um Centro de Estudos e Pesquisas em Administração Municipal (CEPAM), ambas responsáveis pela realização de Seminários, pela criação de estruturas administrativas para a gestão dos referidos consórcios, pela formatação de convênios com o governo do Estado para realização e desenvolvimento de políticas específicas. Além disso, o Estado estava organizado em Administrações Regionais, que faziam o elo entre os interesses locais e as políticas do Governo do Estado.

Apesar disso, a indução (nos termos do neo-institucionalismo da escolha racional) talvez não seja suficiente para explicar a formação de tantos Consórcios Intermunicipais, de um lado porque não foi um processo que ocorreu em todo Estado (apesar de ter ocorrido na maioria do Estado); de outro, porque não se percebe de imediato o ganho dos atores envolvidos com a formação dos referidos Consórcios, de tal modo que não se pode dizer que eles reagiram a uma indução que Ihes propiciaria ganhos, como prevêem os autores do neo-institucionalismo da escolha racional.

Então, além da indução há que se destacar a presença de outro elemento: O empreendedor político. No caso dos Consórcios Intermunicipais no Estado de São Paulo, havia mais de um empreendedor. Pode-se considerar como empreendedor político o próprio governador da época, André Franco Montoro que pregava a descentralização, a democratização e a organização dos municípios em torno de regiões como forma de gerar ganhos de escala e de propiciar a participação efetiva dos mais variados atores políticos e sociais locais. Além do governador, pode-se considerar o então Secretário do Interior, Chopin Tavares de Lima, responsável pelo deslocamento das equipes de técnicos para o interior do Estado para a realização de Seminários e estudos acerca dos Consórcios, pelas visitas que realizava a lideranças e prefeitos pelo 
interior afora, pelo registro e disseminação das experiências em torno dos Consórcios junto aos grandes órgãos de imprensa do Estado, como mecanismo de dar visibilidade aos empreendedores políticos dos Consórcios Intermunicipais.

Além dos dois, há que se destacar a existência de empreendedores políticos locais, responsáveis por sensibilizar e mobilizar prefeitos e técnicos municipais em torno de alguma idéia pertinente à formação dos Consórcios Intermunicipais.

No caso do Estado de São Paulo não se pode falar em uma tradição de cooperação pelos municípios do interior.

Depreende-se, assim, que os Consórcios Intermunicipais que surgiram em São Paulo, ao longo de 1983-1986 são explicados por um conjunto de fatores, dentre os quais, a indução por parte do Governo do Estado de São Paulo e a presença de empreendedores políticos tanto no âmbito do Governo do Estado quanto no âmbito das localidades.

\section{Os Consórcios no Brasil no Período Pós-Constituinte}

A possibilidade da ocorrência de Consórcios Intermunicipais estava prevista indiretamente no inciso $X$ do artigo 30 da Constituição Federal, segundo o qual "compete aos municípios legislar sobre assuntos de interesse local".

A Emenda Constitucional 19 (EC-19/98) tratou diretamente do tema ao afirmar que:

\footnotetext{
"a União, os Estados, o Distrito Federal e os Municípios disciplinarão por meio de lei os consórcios públicos e os convênios de cooperação entre os entes federados, autorizando a gestão associada de serviços públicos, bem como a transferência total ou parcial de encargos, serviços, pessoal e bens essenciais à continuidade dos serviços transferidos".
}

Coincidência ou não, a partir da data da referida Emenda, observou-se aumento do consorciamento entre municípios, ocorrência que passa de 12, em 
abril de 1994 (com 160 municípios consorciados), para 143 em dezembro de 1998 (com 1740 municípios consorciados).

Finalmente, em 6 de abril de 2005 foi promulgada a Lei 11.107, que sistematiza, e especifica as condições para a "contratação" de consórcios públicos, regulamentada recentemente por meio do Decreto 6.107 de 17 de janeiro de 2007.

Apesar da sua atualidade, há pouca sistematização do assunto, articulada com temas clássicos tanto da ciência política quanto da administração pública. O que existe de sistematização pode ser agrupado em três grupos: temático, descritivo abrangente e analítico, este último desdobrado em duas perspectivas: a da "escolha racional" e a do "capital social".

No grupo temático encontram-se os estudos voltados principalmente aos consórcios de saúde (Gil de Lima, 2000; Ribeiro e Costa, 1999), recursos hídricos (Novaes, 2002; Vargas, 1999; Carvalho, 1998; Fujiwara e Jábali, 2001), e meio ambiente, em suas mais variadas vertentes, dentre as quais destacam-se os Consórcios Intermunicipais de resíduos sólidos (Jacobi e Teixeira, 2000; Caldas, 2003) e saneamento (Faria, 2005).

No grupo descritivo abrangente, por sua vez, encontram-se estudos que apresentam, descrevem e analisam casos de consórcios sem a preocupação explícita de construir ou utilizar deliberadamente um campo analítico. Neste grupo estão, por exemplo, os casos da Câmara Regional do Grande ABC (Clemente, 1999; Daniel, 2001), do Consórcio Intermunicipal de Produção e Abastecimento de São Luís do Maranhão (Trindade, 2000; Barboza e Arouca, 2002; Caldas, 2004), do Consórcio Lambari, abrangente no setor de meio ambiente (Kraemer e Castellano, 2005).

Dentre os estudos analíticos, como foi dito, destacam-se aqueles que abordam a constituição de Consórcios Intermunicipais de Saúde pela perspectiva da "escolha racional" (Teixeira, Mac Dowell e Bugarin, 2002a; Teixeira, Mac Dowell e Bugarin, 2002b). O primeiro analisa os consórcios sob a perspectiva da Teoria dos Jogos; e o segundo, sob a perspectiva da Teoria dos Contratos. 
Finalmente, um estudo que aborda a constituição dos consórcios intermunicipais na perspectiva do capital social, realizado por Jacobi (2006), que analisa a origem e o desenvolvimento institucional do Consórcio Ambiental do Quiriri (SC).

Além dos estudos temáticos abordados rapidamente acima, há frágeis informações nacionais sobre os Consórcios Intermunicipais que emergem no país.

O Banco de Dados da Fundação Instituto Brasileiro de Geografia e Estatística (IBGE, 2001) está organizado por municípios pertencentes a consórcios, segundo 14 tipos temáticos ou setoriais (ou por serviços públicos existentes $)^{20}$ e segundo classes de tamanho da população dos municípios. Dessa maneira, não é possível saber ao certo a quantidade de consórcios que cada município participa e tampouco a composição de cada consórcio. Apesar disso, os dados disponíveis possibilitam obter informações relevantes.

A primeira delas é a verificação dos setores em torno dos quais há maior incidência de municípios organizados em consórcios: saúde (1.969 municípios) ${ }^{21}$; aquisição e/ou uso de máquinas e equipamentos (669 municípios); reciclagem de lixo (139 municípios); e coleta de lixo (138 municípios).

Com relação às classes de tamanho da população, observou-se que a incidência de participação dos municípios em todas as classes até 500 mil habitantes obedeceu a seguinte ordem: saúde, aquisição e/ou uso de máquinas e equipamentos, e educação. No caso dos municípios com população entre 100 mil e 500 mil habitantes, o setor educação foi seguido de perto pela categoria "tratamento ou disposição final do lixo".

A única classe que se diferenciou foi a de municípios com população superior a 500 mil habitantes. Neste caso a maior incidência de participação foi na categoria "tratamento ou disposição final do lixo" (12/32 municípios da

\footnotetext{
${ }^{20}$ A pesquisa de Informações Básicas Municipais, 2001, considerou 14 setores em torno dos quais os municípios se organizaram em consórcios: educação, habitação, aquisição e/ou uso de máquinas e equipamentos, serviços de abastecimento sanitário, limpeza urbana, coleta de lixo, coleta seletiva de lixo, reciclagem de lixo, remoção de entulhos, coleta de lixo especial, tratamento ou disposição final de lixo, processamento de dados, e saúde.

${ }^{21}$ Segundo o Ministério da Saúde, em 1999, o Brasil teria 1.740 municípios organizados em 143 Consórcios Intermunicipais de Saúde (CIS).
} 
categoria), seguida pelos "serviços de esgotamento sanitário" (8/32) e "serviços de abastecimento de água" (7/32). A categoria saúde teve a participação de apenas 03 municípios desta classe populacional.

O Banco de Dados agregado do IBGE permite um sobrevôo preliminar sobre a situação dos consórcios brasileiros e possibilita observar que o arranjo cooperativo dos municípios em torno da saúde é definitivamente relevante, muito provavelmente induzido pelas regras que estruturaram o setor ao longo dos anos 90: implantação do Sistema Único de Saúde (SUS) e publicação das Normas Operacionais Básicas (NOBs).

As referidas regras estão muito mais relacionadas com o fato de expressarem a possibilidade real da formação de Consórcios Intermunicipais com repasse de recursos para essas organizações, que propriamente por ganhos individuais para os municípios que eventualmente venham a participar de algum tipo de Consórcio.

Outra observação pertinente é que a diferenciação na incidência de categorias dos municípios com população inferior a 500 mil habitantes provavelmente reflete a tanto a diferença de preocupação dos gestores públicos dos diferentes tipos de municípios quanto a diferenciação dos problemas emergentes nos grandes centros urbanos (altamente relacionados com os municípios grandes) dos municípios rurais (pequenos e médios municípios).

A distribuição de Municípios por regiões mostra que as regiões Sudeste e Sul apresentam mais fortemente a existência de consórcios. Na área de saúde, enquanto $56 \%$ dos municípios do Sudeste e Sul participam de consórcios, no Centro-Oeste, Nordeste e Norte apenas 21\%, 12\% e 10\% dos municípios, respectivamente, estão consorciados.

De fato, os Governos dos Estados de Minas Gerais (Sudeste) e Paraná $(\mathrm{Sul})^{22}$ assumiram o estímulo ao consorciamento de municípios em torno da questão da saúde como políticas de sua incumbência. Os estímulos desses governos para indução do consorciamento entre municípios se expressam no

\footnotetext{
${ }^{22}$ No Estado do Paraná, a expansão de consórcios ocorre após a mudança de governo, em 1995, o que indica que além do estímulo institucional referente à regulação setorial (saúde) houve a indução decorrente de uma política do governo do Estado.
} 
repasse de recursos diretos na cessão de recursos humanos, apoios técnicos e jurídicos, equipamentos e materiais.

No caso específico de Minas Gerais, há um histórico peculiar que deve ser ressaltado. Segundo Rocha e Faria (2004):

"a criação de consórcios intermunicipais em Minas Gerais,
no início dos anos 90, tem origem num programa da
Faculdade de Ciências Médicas, entidade privada de ensino
localizada em Belo Horizonte, que tinha como propósito
ofertar aos seus alunos condições para cursarem a
residência médica".

Tendo em vista o referido propósito, em 1993, o diretor da faculdade e, posteriormente, Secretário da Saúde de Minas Gerais e deputado federal, Rafael Guerra, assume a administração de dois hospitais municipais no interior do Estado, transformando-os em hospitais universitários. Em seguida, inicia o intenso trabalho de convencimento dos prefeitos das respectivas regiões a se consorciarem para financiarem os hospitais. A engenharia institucional criada pelo então diretor da faculdade consistia em criar um jogo "ganha-ganha" entre os parceiros. A Faculdade de Ciências Médicas, que necessitava de infraestrutura para realização do projeto de residência médica assume a administração do hospital e os profissionais especializados necessários para seu funcionamento. Os prefeitos dos municípios consorciados passam a ter oferta de serviços públicos na área da saúde condizentes com as demandas locais. Em contrapartida os prefeitos precisam assumir as despesas proporcionalmente à utilização dos serviços.

Vistos os dados gerais sobre Consórcios Intermunicipais por meio da base de dados do IBGE, busca-se agora um sobrevôo sobre as bases de dados previamente selecionadas, dentre as quais as do Instituto Polis, do Programa Gestão Pública e Cidadania e do CEPAM.

No Instituto Polis, as informações sobre Consórcios estão concentradas no Boletim Dicas, dentre os quais destacam-se os seguintes títulos: Consórcios Intermunicipais (1997), Consórcios de Recursos Hídricos (1998), Consórcios Intermunicipais de Cultura (1998), Consórcio Intermunicipal de Saúde (2000), 
Consórcio de Tratamento de Resíduos Sólidos (2000), Consórcio de Produção e Abastecimento (2002), Câmara do Grande ABC (2004).

No Banco de Dados do Programa Gestão Pública e Cidadania (PGPC/FGV/EAESP), atualizado ano a ano, desde 1996, e organizado em sete categorias - administração pública e governo; infra-estrutura e meio ambiente; serviços públicos; cidadania e direitos humanos; desenvolvimento econômico e social; Poder Legislativo; e Poder Judiciário - havia até 2005 o registro de 24 experiências classificadas como Consórcios Intermunicipais.

As experiências registradas neste Banco de Dados são inscritas por gestores públicos de instâncias subnacionais de governos, ou seja, de governos municipais, estaduais, intermunicipais, ou ainda por organizações próprias dos povos indígenas para participar do Ciclo de Premiação Anual do Programa Gestão Pública e Cidadania ${ }^{23}$.

Entre 1996 e 2005, foram inscritas 7.447 iniciativas identificadas como inovadoras pelos governos subnacionais, das quais, como já foi dito, 24 estão classificados na área correspondente a Consórcios Intermunicipais ${ }^{24}$.

Para efeito de análise nessa pesquisa, considerei apenas as experiências inscritas com essa temática. A classificação é feita pela própria instituição que inscreve o projeto. Dessa forma, priorizei as iniciativas cujas instituições responsáveis avaliam que a sua inovação se dá pelo fato de serem experiências de Consórcios Intermunicipais. Assim, pode haver algum outro consórcio inscrito em alguma outra área e que não consta nessa análise.

Como todas as instituições podem repetir sua inscrição em outros anos, desse total de 24 inscrições, temos de fato 15 Consórcios Intermunicipais, ou seja, nove (09) inscrições foram repetidas ao longo do tempo. A maioria deles oito consórcios - tem como tema central o meio ambiente (resíduos sólidos, preservação ambiental, bacias hidrográficas). Em segundo lugar, há os consórcios de saúde (quatro consórcios) e dois consórcios classificados como

${ }^{23}$ O processo de seleção do Programa Gestão Pública e Cidadania é feito em quatro fases: seleção preliminar, na qual são selecionados 100 semifinalistas; segunda fase, na qual ocorre a seleção de 30 pré-finalistas, que receberão visita de campo; terceira fase, na qual são escolhidos 20 finalistas dentre os 30 pré-finalistas. 24

$\mathrm{Na}$ realidade, não considerei para efeito de análise os projetos inscritos pela Fundação Prefeito Faria Lima - CEPAM - sobre assessoria a Consórcios Intermunicipais. 
gestão regional, dentre os quais o do $A B C$, que teve sua criação relacionada com o tema do meio ambiente (inclusive o nome do consórcio é Consórcio Intermunicipal das Bacias do Alto Tamanduateí e Billings), mas com o passar do tempo, as ações do consórcio se desdobraram em outras temáticas tais como desenvolvimento urbano e desenvolvimento econômico.

Já o Consórcio Intermunicipal de Produção e Abastecimento, na região de São Luis, Maranhão, foi o único consórcio que trata do tema abastecimento.

Dos 15 consórcios analisados, sete se encontram no Sudeste (cinco só em São Paulo), quatro, no Sul e quatro, no Nordeste.

Os dados encontrados no banco de dados do PGPC, de alguma forma, reforçam a análise feita a partir dos dados do IBGE. Ou seja, as regiões Sudeste e Sul têm uma maior incidência de consorciamento entre municípios, não se sabe se isso ocorre, hipoteticamente, pela maior aglomeração de municípios, pelo menor tamanho territorial (o que facilita a integração de determinadas políticas entre municípios vizinhos) ou por um acúmulo histórico de capital social.

Deve-se ressaltar que o Nordeste é a região que mais estados e municípios têm, o que permite um número de inscrições alto no programa.

Com relação às temáticas, os Consórcios aqui analisados e que trabalham com meio ambiente podem ser subclassificados em recuperação ambiental (Consórcio Quiriri - SC e Consórcio de Sousa, Uiraúna e Santa Helena - PB), resíduos sólidos (Citresu - RS), recursos hídricos (Consórcio Iberê - SC, Consórcio dos Rios Santa Maria da Vitória e Jucu - ES, Consórcio dos Rios Piracicaba, Capivari e Junidaí - SP, Consórcio do Ribeirão Lajeado SP e Consórcio do Vale do Jiquiriçá - BA).

Enquanto o Consórcio Quiriri objetiva promover medidas destinadas à recuperação, conservação e preservação do meio ambiente a partir da identificação de áreas viáveis à preservação legal, do estímulo à criação de unidades de conservação junto aos setores público e privado da região, da implementação de ações para garantir a administração, o zoneamento e o plano de gestão das áreas e do tratamento do lixo, o Consórcio de Sousa, Uiraúna e Santa Helena objetiva a conservação dos recursos naturais da 
caatinga, por meio de atividades de silvicultura, ecoturismo e educação ambiental.

O Consórcio Intermunicipal de Tratamento de Resíduos Sólidos Urbanos - Citresu - foi criado para integrar o sistema de coleta, tratamento e destinação final do lixo.

O Consórcio Intermunicipal de Gerenciamento Ambiental - Iberê objetiva a discussão e a implantação, de modo participativo, de uma metodologia de planejamento integrado que respeite a natureza, usando bacias hidrográficas como unidades de gestão, por intermédio de palestras, seminários, reuniões de grupos de trabalhos e cursos de capacitação.

O Consórcio do Ribeirão Lajeado recupera, conserva e preserva a bacia hidrográfica do Ribeirão do Lageado por meio de recomposição da mata ciliar com o plantio de mudas nativas e execução de serviços e intervenções para a redução da erosão e assoreamento tendo em vista a importância dos recursos hídricos para a comunidade como manancial de abastecimento e também para as atividades agropecuárias da micro-região.

Os Consórcios dos Rios Santa Maria da Vitória e Jucu, dos Rios Capivari e Jundiaí e do Vale Jiquiriça objetivam recuperar suas bacias hidrográficas, por meio de projetos de educação ambiental, envolvendo a comunidade local.

No que diz respeito aos Consórcios Intermunicipais de Saúde, durante os nove anos de PGPC, quatro experiência se inscreveram (na categoria consórcios intermunicipais). Os Consórcios Intermunicipais de Saúde visam um planejamento integrado na área da saúde, operando de forma conjunta a rede pública de serviços de saúde, diminuindo os gastos com medicamentos e distribuindo-os aos órgãos competentes consorciados.

Finalmente, no que diz respeito às bases de dados do CEPAM, foram analisados, em ordem cronológica, além dos Boletins do Interior, 05 produtos diferentes, editados ao longo dos anos 90 e início dos anos 2000:

- Catálogo de Experiências Municipais: gestão 93-96; 
- Catálogo de Experiências Municipais: municípios em busca de soluções;

- Catálogo de Experiências Municipais - Rede de Comunicação de Experiências Municipais (RECEM): gestão 1997-2000;

- Catálogo: Municípios Paulistas em Busca de Novas Práticas (2001/2004);

- Publicação: Municípios Paulistas em Busca de Novas Práticas: as 12 finalistas do Prêmio Chopin Tavares de Lima - Novas Práticas Municipais.

Para a edição do primeiro Catálogo, o CEPAM enviou para todos os prefeitos do Estado de São Paulo e, por meio de contatos pessoais e institucionais, a gestores de experiências, 824 roteiros de coleta de informações. Retornaram 96 experiências, todas registradas no referido catálogo, das quais nenhuma referente a Consórcios ${ }^{25}$.

Para a edição do segundo Catálogo, foram enviados 772 roteiros de coletas (para todos os prefeitos do Estado de São Paulo e para gestores de experiências). Retornaram 231 experiências, das quais quatro (04) inscritas como ações diretamente relacionadas com Consórcios Intermunicipais: Câmara do Grande ABC; Consórcio Intermunicipal do Alto tamanduateí e Billings; Consórcio Intermunicipal das Bacias Hidrográficas dos Rios Piracicaba e Capivari; Consórcio Intermunicipal do Ribeirão Lajeado.

Nota-se que as quatro experiências também estão representadas no Banco de Dados do PGPC-FGV.

No terceiro Catálogo, há apenas duas experiências relativas a Consórcios Intermunicipais, ambas inscritas pelo Consórcio Intermunicipal de Lajeado $^{26}$.

\footnotetext{
25 Neste Catálogo não constam experiências referentes a Consórcios Intermunicipais registradas no Índice de Experiências e no Índice de Assuntos.

${ }^{26}$ O Consórcio Intermunicipal do Lajeado envolve três municípios abastecidos pelo referido Ribeirão (Lajeado): Penápolis, Alto Alegre e Barbosa. Trata-se de experiência iniciada em 1990 (fase de realização de diagnóstico) e oficializada em 1992. A experiência contou inicialmente com a Companhia Energética do Estado de São Paulo (CESP) e do Instituto de Pesquisas Tecnológicas (IPT). Deve-se registrar que Penápolis já havia liderado a constituição de dois outros Consórcios Intermunicipais ao longo dos anos 80: Consórcio de Saúde e Consórcio de Informática.
} 
No quarto Catálogo ${ }^{27}$, há um conjunto de 365 iniciativas registradas, das quais 06 registrados como Consórcios Intermunicipais ${ }^{28}$.

Finalmente, a publicação Municípios Paulistas em Busca de Novas

Práticas é fruto do que o Cepam chamou de 12 Experiências finalistas dentre as 365 experiências registradas pelo último catálogo. Dentre as 12 finalistas há duas (02) inscritas como Consórcios Intermunicipais ${ }^{29}$.

Resumidamente, ao longo desta seção que tratou dos Consórcios no Brasil recente, foi possível verificar que:

Para a realização desta publicação foram registradas 365 iniciativas das 624 recebidas. Isso ocorre em função de critérios para a inserção das informações como o preenchimento de todas as questões solicitadas, consistência em relação aos dados, além da exigência de que o projeto/ação/atividade estivesse em funcionamento há mais de um ano. As iniciativas recebidas foram, inicialmente, identificadas em nove grupos temáticos, que nortearam o processamento e a apresentação das informações no Catálogo: Gestão de Serviços; Saúde; Educação e Cultura; Habitação; Geração de Renda; Criança e Adolescente; Esportes e Lazer; Integração Social e Câmara Municipal. Essa organização permitiu a consulta por temas, assunto e município, além dos relatos e respectivas referências das experiências. Após análise foram selecionadas doze experiências a serem visitadas a partir dos seguintes critérios: simplicidade; replicabilidade; alcance social; alteração na prática da rotina; acessibilidade; articulação de diversos atores. 28

As seis experiências são as seguintes: Consórcio Intermunicipal de Saúde, inscrita pelo município de Divinolândia e iniciada em 1987; Consórcio Intermunicipal de Saúde do Vale do Ribeira, iniciado em 1989; Farmácia de Manipulação do CIVAP (Paranapanema)/Saúde, iniciada em 2002; Projeto Colaboradores Ambientais do Ano, iniciado em 2001; Programa de Gestão de Bacia Hidrográfica e Cooperação Institucional, iniciado em 1990; Programa de Educação Ambiental, iniciado em 1994. Estas três iniciativas foram inscritos pelo município de Americana e pertencem a ações do Consórcio Intermunicipal dos Rios Piracicaba, Capivari e Jundiaí (PCJ). 29

As duas iniciativas finalistas inscritas como Consórcios foram: Consórcio Intermunicipal de Saúde - CONDERG (1987) e a Farmácia de Manipulação, iniciativa do Consórcio Intermunicipal do Vale do Paranapanema (2002). O CONDERG é uma parceria entre as Prefeituras da DIRXX (São João da Boa Vista) estimulada ainda pelo Governo Montoro e que perdura até hoje (2007). A Farmácia de Manipulação, por sua vez, é um iniciativa recente (2002), instituída pelo do Consórcio Intermunicipal do Vale do Paranapanema, é uma iniciativa que agrega onze municípios (Assis, Cândido Mota, Cruzália, Florínea, Ibirarema, Lutécia, Maracaí, Nantes, Pedrinhas Paulista, Platina e Tarumã). Após a realização de estudos de viabilidade econômica, foi organizado um modelo de farmácia de manipulação com objetivos expressos de diminuir despesas das Prefeituras do Consórcio com medicamentos; fabricar medicamentos alopáticos e outros produtos de interesse da saúde pública; fornecer produtos aos órgãos municipais de saúde pública e assistência social; gerar emprego e renda na região, entre outros. São fabricados medicamentos (pomadas, cápsulas e xaropes) utilizando matéria prima de síntese própria, aquisição local, importação ou de extração/cultura de origem animal, vegetal ou mineral. O usuário do SUS dos municípios consorciados são os beneficiados diretos e imediatos pela iniciativa. 
As informações do IBGE referentes a $2002^{30}$ indicam que aproximadamente $54 \%$ dos municípios brasileiros participam de algum tipo de Consórcio Intermunicipal; por outro lado, as bases de dados qualitativas consultadas indicam poucas experiências inscritas sob a categoria Consórcios Intermunicipais. Então, se por um lado, há tentativas de "desfragmentar" a ação municipal por meio de iniciativas que busquem a cooperação de municípios próximos uns dos outros; por outro estes mesmos municípios, provavelmente, não reconhecem neste tipo de iniciativa (cooperação intermunicipal) características inovadoras.

\section{Os Consórcios Intermunicipais teriam entrado na Agenda Nacional?}

Nesta seção pretende-se responder à pergunta enunciada no subtítulo: Os Consórcios Intermunicipais teriam entrado na Agenda Nacional? Em outras palavras, os Consórcios Intermunicipais como tema de política pública teria chamado atenção do Governo Federal a ponto tornar-se prioridade?

Para responder a esta questão, propõe-se, inicialmente, verificar a trajetória percorrida pela idéia de institucionalizar os Consórcios Intermunicipais até tornar-se tema discutido em arenas nacionais. Em seguida, identificar e qualificar as arenas e os proponentes dos debates acerca do tema.

O sobrevôo temático apresentado e discutido nas seções anteriores permite-nos identificar, inicialmente, dois atores relevantes: o Governo do Estado de São Paulo, que ao longo dos anos 1983-1986 incentivou a formação dos Consórcios; e os Prefeitos de municípios eleitos naquela época, que aceitaram o desafio do desenvolvimento de Consórcios Intermunicipais e desenvolveram-nos nas mais diversas áreas.

Em seguida, percebe-se certa interrupção do tema no Estado de São Paulo, não porque os Consórcios Intermunicipais tenham deixado de existir, mas porque deixou se ser prioridade do Governo do Estado, ou seja, a indução

\footnotetext{
${ }^{30}$ Dados do IBGE (2005) sobre informações municipais de 2002 indicam que 96 municípios brasileiros participavam de pelos menos 06 Consórcios Intermunicipais diferentes; 996 municípios tinham participação em 02, 03, 04 ou 05 Consórcios Intermunicipais; 1862 municípios participavam de apenas um (01) Consórcio Intermunicipal; e 2545 municípios não participavam de Consórcios Intermunicipais.
} 
deixou de existir e os empreendedores políticos estaduais saíram de cena. No entanto, iniciativas paulistas são inscritas nas diversas bases de informações qualitativas, o que demonstra a permanência das iniciativas e o reconhecimento dos próprios gestores de que a prática do Consórcio continha elementos de inovação para as políticas públicas.

Ao longo dos anos 90, houve a intensificação da prática dos Consórcios Intermunicipais verificada nas Bases de Dados do IBGE. Essa intensificação não ocorreu de forma homogênea: há destaque para o "setor" da saúde e para os Estados do Paraná e de Minas Gerais. Mais uma vez, evidencia-se a presença dos Governos Estaduais incentivando a prática dos Consórcios.

O caso da saúde é o mais emblemático e nesse aspecto as especificidades sobre os consórcios vieram no bojo da estruturação de um sistema universalizado e descentralizado. Os Consórcios Intermunicipais são citados como mecanismos de organização da política do setor (saúde) na Lei Orgânica da Saúde (LOS) quando trata da organização regional dos serviços e ações de saúde.

Existe então uma regulamentação legal (LOS) apresentando os Consórcios Intermunicipais como um instrumento de gestão do SUS para implementação de um sistema integrado e regionalizado. Segundo a lei, a gestão se dá "em relação à integralidade e à universalidade das ações e serviços de saúde em todos os níveis" (CRUZ, 2002: 206) e podem ser constituídos para desenvolver ações e serviços de saúde que lhes correspondam, cabendo inclusive mecanismos de participação cidadã na gestão do sistema e transferências intergovernamentais de recursos financeiros. Isso, entretanto, como já foi dito, não é suficiente para induzir os municípios a participarem de algum tipo de consórcio. Trata-se tão-somente de prerrogativa que, ao expressar a possibilidade de repasse de recursos para os Consórcios e explicitar a possibilidade de adesão a qualquer tipo de Consórcio Intermunicipal de Saúde (CIS), livra o município que pretende ingressar em um consórcio de qualquer tipo de sanção, visto que a Legislação, apesar de frágil com relação ao tema consórcio, cita-o como alternativa viável. 
No caso dos CIS, a indução forte, que cria estímulo por meio de ganhos efetivos, é feita pelos governos estaduais.

A legislação federal de recursos hídricos ${ }^{31}$ também trata dos consórcios. Nela estabelece-se que a bacia hidrográfica é a unidade territorial para implementação da política e associações regionais e os consórcios intermunicipais podem ser vistos como organizações civis capazes de tratar dos problemas territoriais relativos a recursos hídricos.

$\mathrm{Na}$ Assistência Social, seguem-se os princípios da legislação de saúde e a Lei Orgânica de Assistência Social (LOAS) estabelece que o Estado deve estimular e apoiar não apenas os consórcios, mas também as associações.

No caso específico de Minas Gerais, o tema dos Consórcios Intermunicipais entra na agenda do Estado pelas mãos do então Secretário Estadual de Saúde, Rafael Guerra, que até então não havia disputado cargos eletivos. Rafael Guerra fora Diretor da Faculdade de Ciências Médicas.

$\mathrm{Na}$ ocasião em que exercera o cargo de Diretor, Guerra instituira o primeiro Consórcio de Saúde de Minas Gerais (Alves, 1995) com intuito de resolver um problema imediato da faculdade - garantir residência médica para seus alunos. Inicia-se então um processo para a identificação dos atores locais interessados numa questão mais abrangente - a saúde pública local: o principal ator era a prefeitura municipal responsável pelo hospital.

Em seguida, surge a idéia do Consórcio Intermunicipal como mecanismo de reduzir o "efeito carona", ou seja, como mecanismo capaz de internalizar as "externalidades positivas" geradas pela melhoria do hospital.

Em outras palavras, o Consórcio surge como mecanismo capaz de envolver os municípios do entorno que se beneficiariam da melhoria do Hospital no sentido de arcar com parte do custo gerado pela referida melhoria.

Anos depois, com a experiência já divulgada pelos jornais de grande circulação no país e a experiência ampliada pela própria Faculdade em outras regiões de Minas Gerais, há eleições estaduais.

\footnotetext{
${ }_{31}$ Alguns estados como São Paulo, Rio Grande do Sul e Ceará apresentam legislações próprias que estabelecem suas Políticas Estaduais de Recursos Hídricos com referências aos consórcios.
} 
Itamar Franco (PMDB), então governador de Minas Gerais (1995-1998), deixa o Palácio da Liberdade. Eduardo Azeredo (PSDB) assume o governo mineiro (1999) e convida Rafael Guerra para assumir a pasta da Saúde.

Sob o comando de Rafael Guerra, as bandeiras da Secretaria de Saúde passam a ser a municipalização da saúde e a implantação dos Consórcios Intermunicipais. Nesta ocasião, então, pode-se dizer que o Consórcio é tema que pertence a agenda do governo de Minas Gerais.

Em 1995, paralelamente às alterações legais especificas dos setores acima discutidos, o tema dos Consórcios Intermunicipais, já presente na agenda de alguns governos estaduais e de muitos governos municipais, passa a chamar a atenção do Governo Federal, mais especificamente, de um grupo de deputados e também, ainda que de maneira marginal, do Ministério da Reforma do Estado.

Ao longo deste período (primeiro Governo FHC), o tema dos Consórcios é discutido e, por meio da Emenda Constitucional 19 (EC-19/98), passa a ser mencionado literalmente na Constituição Federal como instrumento de cooperação entre municípios:

\footnotetext{
"A União, os Estados, o Distrito Federal e os Municípios disciplinarão por meio de lei os consórcios públicos e os convênios de cooperação entre os entes federados, autorizando a gestão associada de serviços públicos, bem como a transferência total ou parcial de encargos, serviços, pessoal e bens essenciais à continuidade dos serviços transferidos".
}

A partir dessa Emenda se observa uma ocorrência maior de consorciamento entre municípios que passa de 12 em abril de 1994 (com 160 municípios consorciados) para 143 em dezembro de 1998 (com 1740 municípios consorciados).

Como foi dito entretanto neste período há pelo menos três fatos diacrônicos diretamente relacionados com o fortalecimento dos Consórcios Intermunicipais: a eleição do Governador Eduardo Azeredo (PSDB-MG), com a escolha de Rafael Guerra para assumir a Secretaria Estadual de Saúde; a discussão da emenda constitucional 19/98; e as legislações específicas 
relacionadas aos sistemas de políticas públicas (LOAS, LOS, Legislação federal de recursos hídricos).

A partir de 2003, o tema dos Consórcios Intermunicipais readquire força no âmbito nacional, quando o primeiro Governo Lula (2003-2006), por meio da subchefia de assuntos federativos então alocada na Casa Civil, conclui debate sobre a regulamentação dos Consórcios Intermunicipais. Até aquele momento, havia um esforço isolado do deputado Rafael Guerra em colocar na agenda do Congresso Nacional o tema dos Consórcios Intermunicipais para ser votado. $\mathrm{O}$ deputado Rafael Guerra, apresentou um projeto de Lei sobre o assunto, passou pelas Comissões específicas na Câmara e foi apreciado pelo Senado. Em 2003, o Projeto do Deputado entra na pauta de votação do Senado. Paralelamente a isso, o recém empossado governo Lula apresenta ao Congresso Nacional uma nova Lei. Então inicia-se o processo de negociação entre a subchefia de Assuntos Federativos (Casa Civil) e o Deputado Rafael Guerra para chegarem a um acordo sobre uma Lei que regule os Consórcios.

Em 06 de abril de 2005 foi aprovada uma Lei que trata especificamente do assunto. A mesmo foi regulamentada no início de 2007.

Nos termos de Kingdon (2003), o tema entrou na agenda de decisões no âmbito Federal. No entanto, essa entrada ocorreu no Poder Legislativo. No Poder Executivo, a impressão que fica é que os consórcios compõem a agenda de governo como tema a ser tratado e levado em consideração; mas não compõem a agenda de decisões (agenda na qual os três fluxos se entrelaçam e o tema ganha grande relevância).

Muito provavelmente o tema dos Consórcios Intermunicipais não entrou na agenda de decisões, porque, segundo podemos perceber, além de sua institucionalização legal são necessários outros três fatores:

- um grupo de apoio, que alem de ter trabalhado pela institucionalização da política setorial seja capilarizado no território nacional e trabalhe diretamente com os atores locais;

- vinculação de recursos para financiamento da política;

- uma burocracia estatal local que muitas vezes se não é o próprio grupo de apoio, está muito próximo do mesmo. 
Estas três condições se verificam intensamente na política de saúde, razoavelmente em termos da política de gestão de recursos hídricos e; raramente na política de assistência social.

Esses três fatores explicam de alguma forma a diferenciação entre a implementação de consórcios nos três setores de políticas sociais elencados acima, e provavelmente ajuda a explicar a falta de maior interesse do governo Federal.

Em poucas palavras, retomando a questão que deu origem a esta seção, pode-se dizer que os Consórcios Intermunicipais entraram na Agenda do Governo Federal, mas não em sua Agenda de Decisões.

\section{Conclusão}

Neste capítulo, por meio de um recorte temático, foi possível apresentar os Consórcios Intermunicipais no Brasil desde o início dos anos 80 .

O capítulo foi iniciado com uma discussão conceitual de Consórcio Intermunicipal. Em seguida, foi apresentada a metodologia utilizada para o levantamento de informações acerca dos consórcios. Os Consórcios Intermunicipais foram então apresentados a partir das bases de informações das principais instituições do Brasil que lidam com o tema de governos locais.

O que se observou a partir dos dados apresentados é que a essência do debate sobre o tema dos Consórcios Intermunicipais foi lançada ainda nos idos dos anos 80 quando o então Governo Montoro promoveu uma ampla disseminação dessa prática.

Em seguida, foi possível observar a maior incidência de Consórcios Intermunicipais em alguns setores como é o caso do Setor Saúde e construção e manutenção de rodovias.

Foi possível observar com relação às bases de dados utilizadas, que há uma sobreposição de informações entre as mesmas, muito embora as leituras das informações sejam diferentes. No entanto, como para os propósitos deste trabalho, o que se procurava era reconhecer o registro de experiências, a nota de que há sobreposição continua válida. 
Finalmente, ao observarmos que os Consórcios entraram na agenda de governo, mas não na agenda de decisão do governo Federal, fica ainda mais evidente que este fenômeno (Consórcios Intermunicipais) é fruto das iniciativas locais, provavelmente com alguma influência setorial, outras influências legais, algumas influências de governos Estaduais e Federal; mas sobretudo, fruto de uma dinâmica e complexa relação política local (e regional). 


\section{Quadro 01}

Consórcios Intermunicipais de Alimentação (CIA) no Estado de São Paulo 1983-1986

\begin{tabular}{|c|c|c|c|c|}
\hline Consórcio & $\begin{array}{c}\text { Região de } \\
\text { Governo (RG) }\end{array}$ & Sede & Municípios & Atividades \\
\hline CIA da Região de Governo de Assis & RG Assis & $\begin{array}{l}\text { Paraguaçu } \\
\text { Paulista }\end{array}$ & 04 & Canicultura \\
\hline CIA de Matão & RG Araraquara & Matão & 08 & Produção de Leite de Soja \\
\hline $\begin{array}{c}\text { Consórcio de Obras e Programa de } \\
\text { Ação Social } \\
\end{array}$ & $\begin{array}{l}\text { RG Bragança } \\
\text { Paulista }\end{array}$ & Piracaia & 02 & Produção de Leite de Soja \\
\hline $\begin{array}{c}\text { Consórcio dos Municípios da Alta } \\
\text { Mogiana }\end{array}$ & RG Franca & Franca & $17^{*}$ & $\begin{array}{c}\text { Plano de Alimentação Regional e Compra } \\
\text { Conjunta de Medicamentos }\end{array}$ \\
\hline $\begin{array}{l}\text { Consórcio de Desenvolvimento da } \\
\text { RG de Itapetininga }\end{array}$ & RG Itapetininga & Itapetininga & $11^{*}$ & Conservação de Estradas Vicinais \\
\hline ClA e Desenvolvimento & RG Registro & Juquiá & $13^{*}$ & Produção de Banana-Passa \\
\hline Consórcio Anhangüera & RG Ribeirão Preto & São Simão & 05 & Conservação de Estradas Vicinais \\
\hline $\begin{array}{l}\text { Consórcio Intermunicipal para } \\
\text { Produção Alimentar }\end{array}$ & RG Ribeirão Preto & Cajuru & 03 & Operação de Padaria \\
\hline $\begin{array}{l}\text { Consórcio de Alimentação dos } \\
\text { Municípios do Alto Vale }\end{array}$ & $\begin{array}{l}\text { RG São José dos } \\
\text { Campos }\end{array}$ & Jambeiro & 06 & $\begin{array}{c}\text { Produção de Alimentos para Merenda } \\
\text { Escolar }\end{array}$ \\
\hline $\begin{array}{c}\text { Consórcio dos Municípios do Rio } \\
\text { Grande }\end{array}$ & $\begin{array}{l}\text { RG São José do Rio } \\
\text { Preto }\end{array}$ & Icem & 08 & $\begin{array}{c}\text { Produção de Leite de Soja e usina de asfalto } \\
\text { para pavimentação urbana }\end{array}$ \\
\hline $\begin{array}{l}\text { Consórcio Intermunicipal Pró- } \\
\text { Merenda Escolar } \\
\end{array}$ & $\begin{array}{l}\text { RG São José do Rio } \\
\text { Preto }\end{array}$ & $\begin{array}{l}\text { São José do Rio } \\
\text { Preto }\end{array}$ & 07 & $\begin{array}{l}\text { Produção de Alimentos para Merenda } \\
\text { Escolar }\end{array}$ \\
\hline $\begin{array}{c}\text { Consórcio Educação, Município e } \\
\text { Agricultura }\end{array}$ & $\begin{array}{l}\text { RG São José do Rio } \\
\text { Preto }\end{array}$ & Monte Aprazível & 05 & $\begin{array}{c}\text { Produção de Alimentos para Merenda } \\
\text { Escolar }\end{array}$ \\
\hline $\begin{array}{l}\text { Consórcio de Desenvolvimento da } \\
\text { RG de Sorocaba }\end{array}$ & RG Sorocaba & Sorocaba & 15 & $\begin{array}{l}\text { Produção de Alimentos para Merenda } \\
\text { Escolar }\end{array}$ \\
\hline $\begin{array}{c}\text { Consórcio dos Municípios do Médio } \\
\text { e Alto Paraíba }\end{array}$ & RG Taubaté & Taubaté & 03 & $\begin{array}{c}\text { Produção de alevinos e laboratório de } \\
\text { piscicultura }\end{array}$ \\
\hline
\end{tabular}

Fonte: Figueiredo e Montoro (1987).

*Toda Região 
Tabela 01

Municípios Consorciados por tipo de Consórcio, segundo Tamanho da População

\begin{tabular}{|c|c|c|c|c|c|c|c|c|}
\hline \multirow[b]{2}{*}{$\begin{array}{l}\text { Classes de } \\
\text { tamanho da } \\
\text { população dos } \\
\text { municípios }\end{array}$} & \multirow[b]{2}{*}{$\begin{array}{c}\text { Total de } \\
\text { municípios }\end{array}$} & \multicolumn{7}{|c|}{ Municípios por existência de Consórcios Intermunicipais } \\
\hline & & Educação & Habitação & $\begin{array}{c}\text { Aquisição e/ou } \\
\text { uso de } \\
\text { máquinas e } \\
\text { equipamentos }\end{array}$ & $\begin{array}{c}\text { Serviços de } \\
\text { abastecimento } \\
\text { de água }\end{array}$ & $\begin{array}{l}\text { Serviços de } \\
\text { esgotamento } \\
\text { sanitário }\end{array}$ & Limpeza urbana & Coleta de lixo \\
\hline Até 5.000 hab & 1.371 & 47 & 9 & 213 & 23 & 9 & 9 & 33 \\
\hline $\begin{array}{l}\text { De } 5.001 \text { a } \\
20.000 \text { hab }\end{array}$ & 2.688 & 89 & 18 & 293 & 0 & 31 & 33 & 54 \\
\hline $\begin{array}{l}\text { De 20.001 a } \\
100.000 \text { hab }\end{array}$ & 1.275 & 84 & 30 & 140 & 21 & 33 & 34 & 39 \\
\hline $\begin{array}{l}\text { De } 100.001 \mathrm{a} \\
500.000 \mathrm{hab}\end{array}$ & 194 & 16 & 5 & 22 & 10 & 6 & 6 & 7 \\
\hline $\begin{array}{c}\text { Mais de } \\
500.000 \text { hab }\end{array}$ & 32 & 5 & 2 & 1 & 7 & 8 & 3 & 5 \\
\hline Total & 5.560 & 241 & 64 & 669 & 161 & 87 & 85 & 138 \\
\hline
\end{tabular}

\begin{tabular}{|c|c|c|c|c|c|c|c|c|}
\hline \multirow{2}{*}{$\begin{array}{c}\text { Classes de } \\
\text { tamanho da } \\
\text { população dos } \\
\text { municípios }\end{array}$} & \multirow[b]{2}{*}{$\begin{array}{c}\text { Total de } \\
\text { municípios }\end{array}$} & \multicolumn{7}{|c|}{ Municípios por existência de Consórcios Intermunicipais } \\
\hline & & $\begin{array}{c}\text { Coleta seletiva } \\
\text { de lixo }\end{array}$ & $\begin{array}{c}\text { Reciclagem de } \\
\text { lixo }\end{array}$ & $\begin{array}{l}\text { Remoção de } \\
\text { entulhos }\end{array}$ & $\begin{array}{l}\text { Coleta de lixo } \\
\text { especial }\end{array}$ & $\begin{array}{c}\text { Tratamento ou } \\
\text { disposição final } \\
\text { de lixo }\end{array}$ & $\begin{array}{c}\text { Processamento } \\
\text { de dados }\end{array}$ & Saúde \\
\hline Até 5.000 hab & 1.371 & 23 & 41 & 12 & 19 & 42 & 18 & 601 \\
\hline $\begin{array}{l}\text { De } 5.001 \text { a } \\
20.000 \text { hab }\end{array}$ & 2.688 & 45 & 60 & 37 & 42 & 91 & 33 & 985 \\
\hline $\begin{array}{l}\text { De 20.001 a } \\
100.000 \text { hab }\end{array}$ & 1.275 & 27 & 28 & 30 & 34 & 58 & 30 & 330 \\
\hline $\begin{array}{l}\text { De } 100.001 \mathrm{a} \\
500.000 \mathrm{hab}\end{array}$ & 194 & 5 & 5 & 3 & 6 & 13 & 5 & 50 \\
\hline $\begin{array}{c}\text { Mais de } \\
500.000 \text { hab }\end{array}$ & 32 & 5 & 5 & 3 & 4 & 12 & 2 & 3 \\
\hline Total & 5.560 & 105 & 139 & 85 & 105 & 216 & 88 & 1.969 \\
\hline
\end{tabular}

Fonte: IBGE (2001). 
Tabela 02

Municípios Consorciados por tipo de Consórcio, segundo Macrorregião Geográfica

\begin{tabular}{|c|c|c|c|c|c|c|c|c|}
\hline \multirow[b]{2}{*}{$\begin{array}{l}\text { Grandes } \\
\text { regiões }\end{array}$} & \multirow[b]{2}{*}{$\begin{array}{c}\text { Total de } \\
\text { municípios }\end{array}$} & \multicolumn{7}{|c|}{ Municípios por existência de Consórcios Intermunicipais } \\
\hline & & Educação & Habitação & $\begin{array}{c}\text { Aquisição } \\
\text { e/ou uso de } \\
\text { máquinas e } \\
\text { equipamentos }\end{array}$ & $\begin{array}{l}\text { Serviços de } \\
\text { abasteciment } \\
\text { o de água }\end{array}$ & $\begin{array}{l}\text { Serviços de } \\
\text { esgotamento } \\
\text { sanitário }\end{array}$ & $\begin{array}{c}\text { Limpeza } \\
\text { urbana }\end{array}$ & Coleta de lixo \\
\hline Norte & 449 & 22 & 10 & 30 & 14 & 9 & 11 & 11 \\
\hline Nordeste & 1.792 & 91 & 22 & 73 & 55 & 29 & 31 & 34 \\
\hline Sudeste & 1.668 & 59 & 14 & 405 & 40 & 29 & 16 & 21 \\
\hline Sul & 1.188 & 41 & 16 & 130 & 41 & 14 & 21 & 66 \\
\hline Centro-Oeste & 463 & 28 & 2 & 31 & 11 & 6 & 6 & 6 \\
\hline Total & 5.560 & 241 & 64 & 669 & 161 & 87 & 85 & 138 \\
\hline
\end{tabular}

\begin{tabular}{|c|c|c|c|c|c|c|c|c|}
\hline \multirow{2}{*}{$\begin{array}{c}\text { Classes de } \\
\text { tamanho da } \\
\text { população } \\
\text { dos } \\
\text { municípios }\end{array}$} & \multirow[b]{2}{*}{$\begin{array}{c}\text { Total de } \\
\text { municípios }\end{array}$} & \multicolumn{7}{|c|}{ Municípios por existência de Consórcios Intermunicipais } \\
\hline & & $\begin{array}{c}\text { Coleta } \\
\text { seletiva de } \\
\text { lixo }\end{array}$ & $\begin{array}{l}\text { Reciclagem } \\
\text { de lixo }\end{array}$ & $\begin{array}{c}\text { Remoção de } \\
\text { entulhos }\end{array}$ & $\begin{array}{c}\text { Coleta de lixo } \\
\text { especial }\end{array}$ & $\begin{array}{c}\text { Tratamento ou } \\
\text { disposição } \\
\text { final de lixo }\end{array}$ & $\begin{array}{c}\text { Processament } \\
\text { o de dados }\end{array}$ & Saúde \\
\hline Norte & 449 & 6 & 2 & 11 & 5 & 5 & 8 & 45 \\
\hline Nordeste & 1.792 & 21 & 21 & 27 & 17 & 41 & 23 & 212 \\
\hline Sudeste & 1.668 & 19 & 22 & 19 & 26 & 60 & 26 & 937 \\
\hline Sul & 1.188 & 55 & 93 & 20 & 54 & 108 & 25 & 675 \\
\hline Centro-Oeste & 463 & 4 & 1 & 8 & 3 & 2 & 6 & 100 \\
\hline Total & 5.560 & 105 & 139 & 85 & 105 & 216 & 88 & 1.969 \\
\hline
\end{tabular}

Fonte: IBGE (2001). 


\section{Quadro 02}

\section{Consórcios Intermunicipais por categorias analíticas}

\begin{tabular}{|c|c|c|c|c|c|}
\hline Consórcio & $\begin{array}{l}\text { Ano de } \\
\text { criação }\end{array}$ & $\begin{array}{l}\text { Área } \\
\text { temática }\end{array}$ & Municípios & $\begin{array}{c}\text { No. } \\
\text { muni } \\
\text { cípios }\end{array}$ & $\begin{array}{l}\text { Local sede e } \\
\text { Estado }\end{array}$ \\
\hline $\begin{array}{l}\text { Consórcio de } \\
\text { Municípios da Alta } \\
\text { Mogiana - Coman }\end{array}$ & $1985^{32}$ & $\begin{array}{l}\text { Gestão } \\
\text { regional }\end{array}$ & $\begin{array}{l}\text { Altinópolis, Aramina, Batatais, Buritizal, Cristais Paulista, Franca, Guará, } \\
\text { Igarapava, Itirapuã, Ituverava, Jeriquaquara, Miguelópolis, Patrocínio Paulista, } \\
\text { Pedregulho, Restinga, Ribeirão Corrente, Rifaina, São José da Bela Vista }\end{array}$ & 18 & Franca $-\mathrm{SP}^{33}$ \\
\hline $\begin{array}{c}\text { Consórcio } \\
\text { Intermunicipal da } \\
\text { Bacia Hidrográfica } \\
\text { Alto Rio Negro / } \\
\text { Consórcio Quiriri } \\
\end{array}$ & 1995 & $\begin{array}{l}\text { Meio } \\
\text { Ambiente / } \\
\text { recuperação } \\
\text { ambiental }\end{array}$ & Campo Alegre, Corupa, Rio Negrinho e São Bento do Sul & 4 & $\begin{array}{l}\text { São Bento do } \\
\text { Sul - SC }\end{array}$ \\
\hline $\begin{array}{c}\text { Consórcio } \\
\text { Intermunicipal da } \\
\text { Microrregião do } \\
\text { Médio } \\
\text { Jequitinhonha } \\
\end{array}$ & 1997 & Saúde & $\begin{array}{c}\text { Araçuaí, Chapada do Norte, Coronel Murta, Francisco Badaró, Itinga, Jenipapo } \\
\text { de Minas e Virgem da Lapa }\end{array}$ & 7 & Araçuaí - MG \\
\hline $\begin{array}{c}\text { Consórcio } \\
\text { Intermunicipal das } \\
\text { Bacias do Alto } \\
\text { Tamanduateí e } \\
\text { Billings - } \\
\text { Consórcio do } \\
\text { Grande ABC } \\
\end{array}$ & 1990 & $\begin{array}{l}\text { Gestão } \\
\text { regional }\end{array}$ & $\begin{array}{c}\text { Diadema, Mauá, Santo André, São Bernardo do Campo, São Caetano do Sul, } \\
\text { Ribeirão Preto e Rio Grande da Serra }\end{array}$ & 7 & $\begin{array}{l}\text { Santo André - } \\
\text { SP }\end{array}$ \\
\hline
\end{tabular}

32 O Consórcio da Alta Mogiana foi incluído no estudo, por constar no banco de dados do Programa GPC, embora, pelo seu ano de criação, esteja contemplado no item anterior do capítulo em questão.

${ }^{33}$ Atualmente, a sede fica em São João da Barra - SP. Por se tratar de um consórcio antigo, vários municípios começaram a participar dele mais recentemente. São eles: Guairá, Ipuâ, Morro Agudo, Nuporanga, Ortolândia, Sales de Oliveira, São Joaquim, da Barra e Santo Antônio da Alegria. 


\section{Quadro 02 (continuação)}

\section{Consórcios por categorias analíticas}

\begin{tabular}{|c|c|c|c|c|c|}
\hline $\begin{array}{c}\text { Consórcio } \\
\text { Intermunicipal das } \\
\text { Bacias dos Rios } \\
\text { Piracicaba, } \\
\text { Capivari e Jundiaí }\end{array}$ & 1989 & $\begin{array}{l}\text { Meio } \\
\text { Ambiente / } \\
\text { recursos } \\
\text { hídricos }\end{array}$ & $\begin{array}{c}\text { Americana, Amparo, Analândia, Artur Nogueira, Atibaia, Bom Jesus dos Pedrões, } \\
\text { Bragança Paulista, Camanducaia, Campinas, Capivari, Cordeirópolis, } \\
\text { Corumbataí, Cosmópolis, Elias Fausto, Extrema, Holambra, Hortolândia, Ipeúna, } \\
\text { Iracemápolis, Itatiba, Jaguariúna, Limeira, Louveira, Monte Mor, Nova Odessa, } \\
\text { Paulínia, Pedra Bela, Pedreira, Piracaia, Piracicaba, Rafard, Rio Claro, Rio das } \\
\text { Pedras, Saltinho, Santa Bárbara d'Oeste, Santa Gertrudes, Santo Antônio da } \\
\text { Posse, São Pedro, Sumaré, Tuiuti, Valinhos e Vinhedo }\end{array}$ & 42 & $\begin{array}{l}\text { Americana - } \\
\quad \text { SP }\end{array}$ \\
\hline $\begin{array}{c}\text { Consórcio } \\
\text { Intermunicipal de } \\
\text { Gerenciamento } \\
\text { Ambiental - } \\
\text { Consórcio lberê } \\
\end{array}$ & 1999 & $\begin{array}{l}\text { Meio } \\
\text { Ambiente / } \\
\text { recursos } \\
\text { hídricos }\end{array}$ & $\begin{array}{c}\text { Águas de Chapecó, Caxambu do Sul, Chepecó, Cordilheira Alta, Guatambu, } \\
\text { Planalto Alegre e São Carlos }\end{array}$ & 7 & Chapecó - SC \\
\hline $\begin{array}{c}\text { Consórcio } \\
\text { Intermunicipal de } \\
\text { Produção e } \\
\text { Abastecimento } \\
\text { (Cinpra) }\end{array}$ & 1997 & Abastecimento & $\begin{array}{c}\text { Anapura, Axixá, Cantanhede, Coroatá, Humberto de Campos, Matões do Norte, } \\
\text { Morros, Pirapemas, Presidente Juscelino, Rosário, Santa Inês, São João Batista, } \\
\text { São Luís, Viana e Vitória de Mearim }\end{array}$ & 15 & São Luis - MA \\
\hline $\begin{array}{l}\text { Consórcio } \\
\text { Intermunicipal de } \\
\text { Saúde (CIS) }\end{array}$ & - & Saúde & - & - & $\begin{array}{l}\text { Santa Maria - } \\
\quad \text { RS }\end{array}$ \\
\hline $\begin{array}{l}\text { Consórcio } \\
\text { Intermunicipal de } \\
\text { Saúde da Região } \\
\text { Centro do Estado }\end{array}$ & 1993 & Saúde & $\begin{array}{c}\text { Agudo, Arroio do Tigre, Cachoeira do Sul, Caçapava do Sul, Cacequi, Cerro } \\
\text { Branco, Dilermando de Aguiar, Dona Francisca, Faxinal do Soturno, Formigueiro, } \\
\text { Itaara, Ivorá, Jaguari, Jarí, Júlio de Castilhos, Mata, Nova Esperança do Sul, } \\
\text { Nova Palma, Nova Cabrais, Paraíso do Sul, Pinhal Grande, Quevedos, Restinga } \\
\text { Seca, Santa Maria, Santiago, São Francisco de Assis, São João do Polêsine, } \\
\text { São Martinho da Serra, São Pedro do Sul, São Sepé, São Vicente do Sul, } \\
\text { Silveira Martins, Toropi, Tupanciretã e Unistalda }\end{array}$ & 35 & $\begin{array}{l}\text { Santa Maria - } \\
\quad \text { RS }\end{array}$ \\
\hline $\begin{array}{c}\text { Consórcio } \\
\text { Intermunicipal de } \\
\text { Tratamento de } \\
\text { Resíduos Sólidos } \\
\text { Urbanos (Citresu) }\end{array}$ & 1997 & $\begin{array}{l}\text { Meio } \\
\text { Ambiente / } \\
\text { resíduos } \\
\text { sólidos }\end{array}$ & $\begin{array}{c}\text { Bom Progresso, Humaitá, Sede Nova, São Martinho, Crissiumal, Campo Novo e } \\
\text { Três Passos }\end{array}$ & 7 & $\begin{array}{l}\text { Três Passos - } \\
\quad \text { RS }\end{array}$ \\
\hline
\end{tabular}




\section{Quadro 02 (continuação)}

Consórcios por categorias analíticas

\begin{tabular}{|c|c|c|c|c|c|}
\hline $\begin{array}{c}\text { Consórcio } \\
\text { Intermunicipal do } \\
\text { Ribeirão Lajeado }\end{array}$ & 1991 & $\begin{array}{c}\text { Meio } \\
\text { Ambiente / } \\
\text { recursos } \\
\text { hídricos }\end{array}$ & Alto Alegre, Barbosa e Penápolis & 3 & $\begin{array}{l}\text { Penápolis - } \\
\text { SP }\end{array}$ \\
\hline $\begin{array}{l}\text { Consórcio } \\
\text { Intermunicipal do } \\
\text { Vale do Jiquiriçá }\end{array}$ & - & $\begin{array}{c}\text { Meio } \\
\text { Ambiente / } \\
\text { recursos } \\
\text { hídricos }\end{array}$ & - & - & Salvador - BA \\
\hline $\begin{array}{c}\text { Consórcio } \\
\text { Intermunicipal do } \\
\text { Vale do } \\
\text { Paranapanema / } \\
\text { Saúde - CIVAP }\end{array}$ & 2000 & Saúde & $\begin{array}{c}\text { Assis, Cândido Mota, Cruzália, Florínea, Ibirarema, Lutécia, Maracaí, Nantes, } \\
\text { Pedrinhas Paulista, Platina e Tarumã }\end{array}$ & 11 & Tarumã - SP \\
\hline $\begin{array}{c}\text { Consórcio } \\
\text { Intermunicipal para } \\
\text { Recuperação das } \\
\text { Bacias } \\
\text { Hidrográficas dos } \\
\text { Rios Santa Maria } \\
\text { da Vitória e Jucu }\end{array}$ & - & $\begin{array}{c}\text { Meio } \\
\text { Ambiente / } \\
\text { recursos } \\
\text { hídricos }\end{array}$ & - & - & Vitória - ES \\
\hline $\begin{array}{c}\text { Consórcio Sousa, } \\
\text { Uiraúna e Santa } \\
\text { Helena }\end{array}$ & 1996 & $\begin{array}{c}\text { Meio } \\
\text { Ambiente / } \\
\text { recuperação } \\
\text { ambiental }\end{array}$ & Sousa, Uiraúna, Santa Helena e Triunfo & 4 & Sousa - PB \\
\hline
\end{tabular}

Fonte: Programa Gestão Pública e Cidadania (http://inovando.fgvsp.br) e CACCIA-BAVA, PAULICS, SPINK (2002). 


\section{Capítulo 3: \\ O Caso do Consórcio Intermunicipal de Abastecimento e Produção - MA}

\section{Introdução}

O Consórcio de Produção e Abastecimento de São Luís - CINPRA - tem dez anos de existência, e a experiência acumulada por ele foi reconhecida como experiência de gestão pública inovadora e premiado em três ciclos de premiação nacional sobre o tema: duas vezes (1999 e 2001) pelo Programa Gestão Pública e Cidadania (PGPC), parceria da FGV, da Fundação Ford e do BNDES; e uma vez (2003) pelo SEBRAE-Nacional (Prefeito empreendedor - Prêmio Mario Covas).

A experiência do CINPRA também está registrada nos principais bancos de dados sobre políticas públicas e práticas inovadoras do Brasil, tais como o Banco de Dados do PGPC, do Instituto Polis, e na base de dados sobre Consórcios da Presidência da República.

Estes reconhecimentos indicam que, na pior das hipóteses, essa experiência tem algo a mostrar e foi se legitimando neste campo de construção do conhecimento.

Diante disso, neste capítulo, buscaremos entender como surge e se fortalece a experiência do CINPRA em São Luís do Maranhão.

Este capítulo está organizado em três seções, além desta introdução e das conclusões: Caracterização sociopolítica de São Luís - MA; Histórico e Caracterização do CINPRA; Consolidação do CINPRA.

\section{Caracterização sociopolítica de São Luís (MA)}

O Maranhão é um Estado diferente dos demais Estados do Nordeste, pelo menos no que diz respeito às suas características naturais: não é árido e seco; e a vegetação é verde e diversificada, com água abundante, indicando a proximidade com o clima úmido amazônico. 
Mais de $40 \%$ da população maranhense vive no meio rural e só a partir dos anos 90, passou a predominar a população urbana, concentrada na llha de São Luís, formada pela capital (São Luís) e outros três municípios (Paço do Lumiar, Raposa e São José do Ribamar), respectivamente, com a seguinte população: 978.824 (São Luís), 97.689 (Paço do Lumiar), 20.698 (Raposo) e 130.448 (São José do Ribamar) $)^{34}$.

Do ponto de vista social, o Maranhão registra um dos mais baixos Índices de Desenvolvimento Humano do Brasil $(0,647)$, ganhando apenas de Alagoas $(0,633)^{35}$.

Do ponto de vista financeiro, os municípios maranhenses são altamente dependentes de transferências de recursos federais e estaduais.

Do ponto de vista econômico, apesar das características rurais, o setor agropecuário representa apenas $13,7 \%$ do PIB do Estado. Como indicam matérias de jornal e o ex-secretário executivo do CINPRA, apesar da farta quantidade de terra e do clima generoso, o Maranhão é "importador líquido" de produtos alimentícios de outros Estados brasileiros.

Do ponto de vista político, o Maranhão, desde a década de 60 tem sua história política marcada pela liderança de poucos políticos. Glauber Rocha, em 1967, lançou o filme "Maranhão 66" no qual mostra a posse de José Sarney como Governador eleito do Maranhão. Desde esta época a história política do Maranhão passa necessariamente pela família Sarney e seus aliados. Assim, no "leque político" do Maranhão tem-se, por um lado, a família Sarney e seus aliados; por outro, os outros. É bem verdade, que ao longo do tempo os aliados e os opositores vão se alternando. Algumas vezes, aliados se afastam e passam a atuar na oposição; outras vezes, opositores se aproximam e compõem a situação.

\footnotetext{
${ }^{34}$ Esses dados populacionais são do IBGE (estimativa para 2005).

${ }^{35} \mathrm{O}$ Índice de Desenvolvimento Humano (IDH) dos Municípios e dos estados brasileiros foi calculado pelo Instituto de Pesquisas Econômicas Aplicadas (IPEA) e pela Fundação João Pinheiro (FJP), com apoio do Programa das Nações Unidas para o Desenvolvimento (PNUD). Para o ano de 2000, o maior IDH estadual foi do Distrito Federal $(0,844)$, seguido por São Paulo $(0,814)$. 0 menor IDH foi de Alagoas $(0,633)$ seguido pelo Maranhão $(0,647)$.
} 
No período de redemocratização do Brasil, José Sarney, que fora da ARENA e do PDS, partidos da base do Regime Militar, ajuda a formar a Frente Liberal, e, em 1985, torna-se vice-presidente na chapa de Tancredo Neves para concorrer às eleições indiretas para Presidente da República.

As candidaturas regionais para os governos estaduais passam por essa negociação, de tal modo que, em 1986, na eleição para o governo do Estado do Maranhão, José Sarney apóia a candidatura de Epitácio Cafeteira ${ }^{36}$ que até aquele momento era do PMDB.

Em 1990, Edison Lobão ${ }^{37}$, com apoio da família Sarney, vence as eleições para o Governo do Estado. Em 1994 é a vez de Roseana Sarney ${ }^{38}$ eleger-se governadora do Estado e reeleger-se em 1998. Em 05 de abril de 2002, Roseana Sarney se desliga do governo do Estado para iniciar sua pré-campanha à Presidência da República, pelo PFL. Nessa ocasião, assume o então vicegovernador, José Reinaldo Tavares ${ }^{39}$. Em 2003, José Reinaldo é reeleito governador do Estado com apoio da família Sarney, derrotando o então ex-prefeito de São Luís, Jackson Lago.

As disputas eleitorais em São Luís são acirradas ao longo deste período. Ao longo dos anos 80 e 90, diferentemente das eleições estaduais que têm apenas um pólo, a família Sarney, em torno da qual se desenrolam os processos eleitorais; na cidade de São Luís, há a presença marcante do Partido Democrático

\footnotetext{
${ }^{36}$ Epitácio Cafeteira foi Deputado Federal pelo Maranhão (1963-1965 e 1975 e 1987), Prefeito de São Luís (1965-1969). Foi também governador eleito no Maranhão (1987-1990) e Senador (19911998). Candidatou-se a governador do Maranhão outras duas vezes, além de 1986: em 1994 e 1998, em ambas, é derrotado por Roseana Sarney.

${ }^{37}$ Edison Lobão foi Deputado Federal pelo Maranhão (1979-1982, 1983-1986), Senador (19871991), quando renuncia ao cargo para assumir o governo do Estado (1991-1994) em eleição vencida nas eleições de 1990. Em 1995 volta ao Senado para cumprir mandato até 2002. Em 2003 é reeleito Senador.

${ }^{38}$ Roseana Sarney, filha do ex-presidente da República José Sarney, foi Deputada Federal pelo Maranhão (1991-1994), Governadora (1995-1998, 1999-2002) e Senadora (2003-2008).

39 José Reinaldo, engenheiro, fez sua carreira política assumindo cargos importantes ao longo dos mandatos de José Sarney. Foi Ministro dos Transportes e Secretário de Estado. Em 2004, rompe com a família Sarney. Em 2006, apóia a candidatura de Jackson Lago para o Governo do Estado, em oposição à candidatura de Roseana Sarney.
} 
Trabalhista (PDT) e da liderança de Jackson Lago, contrapondo-se à família Sarney.

Em São Luís, Jackson Lago ${ }^{40}$ disputou as eleições municipais em 1985, a primeira eleição direta para prefeito das capitais após o golpe militar de 1964, e foi derrotado. Em 1988, em nova disputa, Jackson Lago foi eleito prefeito de São Luís, cargo que voltou a assumir em outras duas ocasiões: 1996 e 2000.

Jackson Lago disputou o governo do Estado pela primeira vez em 1994, quando concorreu com Roseana Sarney e com Epitácio Cafeteira, de quem fora Secretário Estadual da Saúde entre 1987 e 1988; em 2002, disputou o Governo do Estado pela segunda vez, e foi derrotado por José Reinaldo (então apoiado pela família Sarney). Finalmente, em 2006, ao disputar pela terceira vez o Governo do Estado, Jackson Lago, elegeu-se Governador.

Especificamente com relação ao CINPRA, deve-se destacar que este fora implantado num contexto de desestruturação dos organismos federais e estaduais de assistência ao produtor rural.

No início dos anos 90, o Presidente Fernando Collor de Mello extinguiu a Empresa Brasileira de Assistência Técnica e Extensão Rural (Embrater) e deixou a critério dos governadores estaduais a decisão de, por intermédio de suas respectivas empresas estaduais (Emater), continuarem ou não atuando nessa área.

\footnotetext{
40 Jackson Lago, médico, fez carreira política junto aos movimentos de redemocratização do país, participando do Movimento pela Anistia nos anos 70. Em 1974, quando o então MDB e os movimentos de oposição ao Regime Militar, decidem a pedir voto e a não mais fazer campanha pelo voto nulo, Jackson Lago candidata-se e elege-se Deputado Estadual no Maranhão. Em 1979, viaja para Lisboa para ajudar Leonel Brizola a montar o que viria a ser o PDT. Organiza, no início dos anos 80, o PDT no Maranhão. Jackson Lago candidata-se a Prefeito de São Luís, em 1985 (não se elege); e a Deputado Federal, em 1986, quando foi o candidato mais votado do PDT e o quarto mais votado do Estado, mas como o PDT não atinge o coeficiente eleitoral, não se elegeu. Em 1988, volta a ser candidato a Prefeito em São Luís e, desta vez, elege-se. Em 1992, elege sua sucessora na Prefeitura. Em 1994, disputa pela primeira vez o Governo do Estado, e é derrotado por Roseana Sarney. Em 1996, volta a eleger-se prefeito de São Luís, e reelege-se em 2000. Em 05 de abril de 2002, deixa a Prefeitura de São Luís, para disputar pela segunda vez o Governo do Estado, e é derrotado por José Reinaldo (que naquele momento recebera apoio da família Sarney). O vice-prefeito de Jackson Lago, Tadeu Palácio, termina o mandato (2002-2004) e reelege-se para o período 2005-2088. Em 2006, Jackson Lago disputa pela terceira vez o Governo do Estado e elege-se governador.
} 
No Maranhão, o então governador Edison Lobão decidiu encerrar as atividades da Emater. A tendência de desestruturação do setor de apoio técnico e extensão rural foi agravada pela Reforma Administrativa promovida pela governadora Roseana Sarney (1997-2000) que resolvera extinguir 18 secretarias estaduais e outros órgãos da administração indireta, dentre os quais a Empresa Maranhense de Pesquisa Agropecuária (Emapa).

Do descrito, percebe-se:

- Que a luta política no Maranhão é travada por dois pólos, dos quais um, por muito tempo, ficou restrito à Ilha de São Luís, com pouca expressão político-eleitoral no resto do Estado (força articulada em torno de Jackson Lago e do PDT); e outro, reuniu, em torno de si, o apoio de meios de comunicação e de líderes políticos locais em todo o Estado (família Sarney). Ao longo do período descrito, nota-se também que a referência principal é a família Sarney que, aliás, vai, aos poucos, perdendo força no Estado a ponto de perder as últimas eleições Estaduais (2006);

- Que as características econômicas do Estado indicam uma alta dependência de produtos alimentícios "importados" de outros Estados (mesmo num território com clima favorável à agricultura vistas) vista pelos gestores públicos locais, até meados dos anos 90, apenas como uma situação "natural". Esta situação no caso específico de São Luís é relida ou reconstruída como um problema público passível de intervenção estatal;

- Que o desmonte dos órgãos de apoio à agricultura num Estado com as características rurais descritas acima, gera uma janela de oportunidade para implementar uma alternativa a um eventual problema de produção e abastecimento no Estado e, em especial, na llha de São Luís.

Assim, a conjuntura política garante os elementos para que o CINPRA, no momento de sua constituição, se auto-defina como uma política pública que busca a cooperação dos municípios para ampliar, melhorar e diversificar a produção rural. 
A conjuntura analisada permite ao grupo político ligado a Jackson Lago e ao PDT identificar os três elementos iniciais que criam a identidade da política de abastecimento e produção de São Luís, quais sejam: cooperação, municipalização, e agricultura.

São estes três elementos que articulam todo o discurso em torno do qual se formou o CINPRA.

A conjuntura política do Maranhão apresentada e analisada acima traz, além dos elementos pertinentes para a criação da identidade do CINPRA, elementos outros que permitem ao grupo político de Jackson Lago e do PDT caracterizar uma pretensa oposição a qualquer política pública pautada na cooperação intermunicipal e na municipalização da agricultura. A oposição, no caso do CINPRA é a família Sarney e o grupo político que está no governo do Estado. Esta oposição é caracterizada pela ausência, pela falta: ausência de uma política pública direcionada aos produtores rurais e conduzida pelo Estado, dado o desmonte das instituições de pesquisa, extensão e assessoria técnica no setor rural.

Finalmente, é possível identificar um "pano de fundo", ou seja, um princípio de totalidade que diz respeito "ao sistema de ação histórica cujos adversários situados na dupla dialética das classes sociais, disputam entre si a dominação" (Touraine, 1973: 347).

Para os termos do CINPRA, esse princípio de totalidade diz respeito aos elementos mais "totalizantes", mais abrangentes do processo, quais sejam, a cooperação e a municipalização, muitos embora estes elementos estejam inseridos em contextos específicos e locais e digam respeito a uma situação muito concreta: a produção rural dos municípios.

Assim, a construção do discurso em torno do CINPRA tem uma dimensão prática, administrativa e imediata, que é favorecer o abastecimento de um grande centro e a produção rural tanto da capital quanto dos demais municípios maranhenses (dada a existência de um mercado consumidor potencial na capital do Estado); e uma dimensão política em torno da disputa pelo poder do Governo 
do Estado, perceptível quando se observa o "opositor" real mas reconstruído pelo grupo de Jackson Lago e do PDT e o princípio da totalidade que identifica uma luta mais ampla que a questão do abastecimento e da produção.

Do ponto de vista da disputa pela dominação, vê-se, por meio do contexto político do Estado do Maranhão, a nítida existência de dois grupos: um que é liderado pela família Sarney, que permeia todo o Estado; e outro, liderado por Jackson Lago (e pelo PDT), que é forte na capital do Estado.

Nos termos de Kingdon, esta-se formando um cenário, um clima, um humor, favorável à implantação de uma nova política pública.

O cenário político apresentado nos permite identificar, em 1997, um clima propício a mudanças no setor das políticas de apoio ao pequeno agricultor, em decorrência de um duplo movimento: o desmonte dos órgãos da administração indireta no Estado, por um lado; e a eleição de Jackson Lago, por outro.

O que o cenário, em si, não permite vislumbrar é se a situação da agricultura, em si, está estruturada na forma de um problema a ser enfrentado por uma política pública; se há alternativas para o enfrentamento do problema; quais os atores em torno dos quais se construíra alguma alternativa se é que esta alternativa ainda não existe; e quem cumprirá decodificará a situação do abastecimento e da produção em problema de política pública, vasculhará a "lata de lixo" para ver se encontra alternativas para a resolução do problema criado, e aproveitará a oportunidade criada pela conjuntura política.

\section{Histórico e Caracterização do CINPRA}

Quando o CINPRA foi concebido? É difícil estabelecer com precisão quando o CINPRA foi concebido. No entanto, é possível estabelecer dois eixos de fatos e acontecimentos que, ao convergirem, contribuem para identificar a concepção e a gênese do CINPRA. São eles:

- A experiência prévia trazida pelo Secretário Municipal de Agricultura, Léo Costa, que fôra prefeito de Barreirinha (1989-1992); 
- Os desafios impostos para a pasta da Agricultura no governo do Município de São Luís, em 1997, quando Jackson Lago assume o governo municipal.

Na condição de prefeito (1989-1992), Léo Costa ${ }^{41}$ sentiu-se só para articular questões que demandavam uma ação coletiva entre municípios. É bem verdade que, na época, o então prefeito não soubesse formular a questão nesses termos como revelara em entrevista. Tampouco procurou os prefeitos vizinhos. Em vez de conversar com as outras prefeituras, foi conversar com o Governo do Estado. Não logrou êxito. Continuou pensando e agindo em sua circunscrição.

Preocupado com a produção rural e a melhor utilização da área ociosa do território, Léo Costa inicia, em seu município, a Campanha da Acerola, e resolve criar uma Escola Agrícola para as crianças que moravam próximas da prefeitura.

Nessa ocasião, o então prefeito de Barreirinha começa a formular um problema relacionado com o abastecimento de São Luís, grande centro consumidor do Estado articulado com a produção de hortifrutigranjeiros dos municípios maranhenses que poderiam constituir-se em um cinturão verde da capital.

A idéia era de que os caminhões que chegassem da capital, deixariam mantimentos e insumos agrícolas nos "povoados", e levariam destes a produção agrícola. Cada povoado teria, então, um "Centro de Negócios" nas proximidades das estradas.

Em 1996, quando da eleição de Jackson Lago em São Luís, este convida Léo Costa para assumir a Secretaria Municipal de Agricultura, e começou o trabalho por meio da verificação de como era feito o abastecimento de São Luís.

O diagnóstico foi fundamental para a construção de um discurso segundo o qual o aumento da população de São Luís, decorrente das dinâmicas migratórias

\footnotetext{
${ }^{41}$ Léo Costa é o apelido de Arieldes da Costa, (61 anos), nascido em Barreirinhas, primeiro secretário executivo do CINPRA. Léo Costa é sociólogo, ex-funcionário da SUDENE (1966-70) e ex-prefeito Barreirinhas (1989-1992). É fundador estadual do PDT. Esta no PDT desde a primeira Comissão Provisória, formada por 11 membros, instituída em 1980.
} 
aumentavam a demanda interna por alimentos e não implicava, necessariamente, no aumento da oferta, ainda que houvesse áreas ociosas.

Por meio de reportagens e matérias veiculadas nos principais jornais do Estado do Maranhão, observamos que muitas informações do diagnóstico elaborado passaram a circular na cidade e no Estado. Segundo as referidas matérias, $80 \%$ do abastecimento do CEASA de São Luís são compostos por produtos oriundos de outros Estados brasileiros.

Efetivamente, a construção de indicadores e a veiculação de informações auxiliam na construção de novas realidades sociais. Os setores técnicos e os produtores rurais tornaram-se mais sensíveis em discutir a possibilidade da formação de um cinturão verde em torno da cidade.

Assim, a gestação do CINPRA é fortemente influenciada pela trajetória e pela experiência acumuladas do Secretário Municipal de Agricultura de São Luís; e pela forma como o tema vai se constituindo como um problema público e político passível de ser resolvido pelo empenho governamental.

O problema que possibilita a viabilidade do CINPRA está formulado, mas o CINPRA como solução ainda não existe.

Como formar o cinturão se cada prefeitura é autônoma e nem todas tem o mesmo entendimento sobre a questão? Aliás, nem todas as prefeituras entenderam a situação da produção articulada com o abastecimento de São Luís como um problema de política pública.

Paralelamente a essa formulação, havia, no interior do Governo de Jackson Lago, em São Luís, uma tentativa de discutir "questões metropolitanas". O secretário responsável pela "metropolização" fracassou em sua missão, dentre outros motivos, porque "partidarizou" uma ação de governo que envolvia uma gama diversa de partidos.

Segundo Léo Costa:

“'Quem quer pegar a galinha não pode dizer xô!'. Então se você quer juntar prefeito, ainda mais de partidos diferentes, você não 
vai falar de partidos políticos. Deve-se chamar os gestores públicos relacionados com o tema e mostrar que a parceria é favorável para todas as partes".

Ainda, segundo Léo Costa, aqueles que não forem convencidos por meio do entendimento inicial, o serão, com o tempo, por meio de demonstrações reais e efetivas do que se pretende, com resultados palpáveis. Este processo de convencimento está muito próximo daquilo que os neo-institucionalistas sociológicos chamam de comportamento estratégico prático, ou seja, um comportamento que embora não seja induzido por meio de esquemas estruturados de estímulos e punições; é um comportamento modificado ao longo do processo pela percepção do agente político (no caso, do prefeito de algum município pertencente à área de abrangência do Consórcio Intermunicipal) que a adesão a determinada prática (ao Consórcio Intermunicipal) traz ganhos materiais e práticos ao município, como por exemplo, a realização de cursos e a implementação de alguma "vitrine tecnológica" no município

Esse duplo acontecimento - a necessidade de ação coletiva para formatação do cinturão verde, e o mal sucedido processo de metropolização foram elementos fundamentais para o início de uma conversa sobre "consórcios".

A partir da indagação de como agir sobre os outros municípios para formar o referido cinturão, se não há condição institucional, dado que cada município é autônomo e nem todos os prefeitos percebem e reconhecem a questão da produção e do abastecimento como um problema de política pública a ser resolvido por meio de intervenção estatal; surge a idéia do Consórcio Intermunicipal como organização capaz de induzir novos comportamentos por parte dos atores políticos no âmbito dos municípios.

Deve-se ressaltar que o Prefeito de São Luís, Jackson Lago, em princípio, era contra esse tipo de ação por meio da Secretaria da Agricultura. Para o prefeito, segundo esclarece Léo Costa e confirma Marco Aurélio (assessor do CINPRA), Jackson Lago queria ações iniciais da própria prefeitura no município de São Luís; depois, quem sabe, uma ação conjunta. 
Ainda assim, aceitou o risco, embora não acreditasse na possibilidade real de viabilizar ações conjuntas sem demonstrações prévias de que os municípios (como São Luís) são capazes de atuar no setor da agricultura, independentemente do desmonte dos órgãos estaduais.

Então, a equipe da Secretaria da Agricultura de São Luís começa a procurar os municípios. No final de quase um ano (13 de outubro) de trabalho, 13 municípios assinaram o "pacto pela produção e pelo abastecimento". O lema era "municípios unidos ajudando o Maranhão a produzir".

Assim, o Consórcio Intermunicipal de Produção e Abastecimento (Cinpra) de São Luís do Maranhão foi criado em outubro de 1997, depois de meses de discussão com diversos prefeitos de municípios próximos à capital maranhense.

Os prefeitos envolvidos na criação do CINPRA pertenciam a partidos diferentes, compreendendo desde o Partido dos Trabalhadores (PT) e o Partido Democrático Trabalhista (PDT) até o Partido do Movimento Democrático Brasileiro (PMDB) e o Partido da Frente Liberal (PFL), passando pelo Partido Socialista Brasileiro (PSB) e o Partido Trabalhista Brasileiro (PTB).

O CINPRA foi fundado por 13 municípios que elaboraram separadamente projetos de lei solicitando às suas respectivas Câmaras Municipais autorização para participação no consórcio e destinação de $0,5 \%$ do volume dos recursos do Fundo de Participação Municipal ao referido Consórcio ${ }^{42}$.

Desde a sua fundação, os objetivos do Cinpra estiveram diretamente relacionados com um setor específico de políticas públicas e mesmo de atividades econômicas - o setor "rural", principalmente relacionado ao pequeno agricultor.

\footnotetext{
${ }^{42}$ O grupo de técnicos da Secretaria de Agricultura de São Luís que organizou as reuniões preparatórias para a formação do CINPRA preparou um modelo de Anteprojeto de Lei que autoriza o Poder Executivo Municipal a participar do Consórcio Intermunicipal de Produção de Abastecimento de São Luís; apresentou também um modelo de Mensagem a ser enviado pelos Prefeitos Municipais aos Presidentes das Câmaras Municipais solicitando autorização para o Município participar do CINPRA. Estes modelos estão nos Anexos 4 e 5 deste trabalho.
} 
Do ponto de vista organizacional ${ }^{43}$, o Cinpra é dirigido pelo colegiado de prefeitos dos municípios (Conselho dos Prefeitos), que se reúne a cada três meses (o Conselho de Prefeitos elege um presidente e um vice-presidente); e operacionalizado por uma secretaria executiva. Há também um conselho fiscal e o Fórum permanente dos Secretários Municipais de Agricultura, que se reúne uma vez por mês.

A Secretaria Executiva trabalha em conjunto com o Fórum de Secretários de Agricultura e tem o objetivo de estudar, pesquisar e planejar ações conjuntas, na perspectiva de dotar cada secretaria municipal do máximo de capital social. Entende-se por capital social, acesso a rede de técnicos e a possibilidade de encontrar outros atores que desenvolvem a mesma atividade econômica.

O grupo executivo que implementa as decisões tomadas, foi formado por dez técnicos, sendo seis vinculados à Secretaria de Agricultura de São Luís, e os demais pagos com recursos próprios do Consórcio.

Uma das atividades mais importantes dos técnicos do Cinpra é o auxílio às secretarias de agricultura na elaboração, encaminhamento e acompanhamento de projetos de expansão e diversificação produtiva. Tais projetos destinam-se tanto à produção agrícola, com a introdução de novas modalidades de plantio, quanto à produção animal, como o projeto de caprinocultura e piscicultura. Há também projetos relacionados ao aumento da produtividade das roças, por meio da utilização de técnicas mais eficazes.

De acordo com a pesquisa e com as entrevistas realizadas, o funcionamento do CINPRA é, em grande parte, fruto do trabalho e do comprometimento da Secretaria Executiva e do Fórum permanente dos Secretários Municipais de Agricultura, que cumprem papel permanente de convencimento dos parceiros, dos prefeitos (a pagarem a parcela mensal) e, ao mesmo tempo, realizam o trabalho técnico de visitas aos municípios e de desenvolvimento das "vitrines tecnológicas". Ressalta-se ainda a importância do

${ }^{43} \mathrm{O}$ organograma de funcionamento do CINPRA não é diferente do organograma da maioria dos Consórcios Intermunicipais implantados tanto nos anos 80 quanto nos anos mais recentes. $O$ modelo de organograma do CINPRA está no Anexo 7. 
município pólo, no caso específico do CINPRA, São Luís. Sem a participação de São Luís, pelo menos, no período inicial, as dificuldades para implantação do CINPRA teriam sido grandes, principalmente em termos financeiros.

Os recursos utilizados no financiamento das diversas ações e na própria manutenção do Cinpra estão divididos em dois blocos: em recursos humanos e recursos financeiros.

Os recursos humanos compõem o grupo executivo do Cinpra. São 10 técnicos, sendo seis vinculados à Secretaria de Agricultura de São Luís, e pagos com recursos do orçamento da capital, e 4 técnicos pagos com recursos do próprio Consórcio.

Quanto aos recursos financeiros, estão concentrados nos $0,5 \%$ das parcelas do Fundo de Participação dos Municípios de cada Prefeitura participante do CINPRA. O valor é descontado automaticamente da conta bancária de cada município a cada 10 dias, e financia programas de assistência técnica e extensão rural. Essa destinação de recursos é regulamentada por leis municipais que autorizam o débito automático.

Além disso, há recursos adicionais advindos de convênios assinados pelo consórcio.

Do ponto de vista dos resultados, o que se verifica é o desenvolvimento das "vitrines tecnológicas", por meio da estruturação de Projetos implantados nas cidades que disponibilizassem pessoal para a manutenção do mesmo ${ }^{44}$.

Para os propósitos deste trabalho, vale ressaltar que o "modus operandi" de implantação de cada um desses projetos (vitrines tecnológicas) cumpria uma certa rotina: definição do projeto a ser desenvolvido definida no Fórum Permanente dos

\footnotetext{
${ }^{44}$ Ao longo do tempo, foram desenvolvidos os seguintes projetos piloto, que depois foram disseminados pelos municípios e pelos povoados (dos municípios) que estavam inseridos no CINPRA: Projeto Caju, com envolvimento da Associação Joanina dos Plantadores de Caju e o desenvolvimento de uma Unidade de Processamento de Castanha; Projeto Hortaliças, com o desenvolvimento de dois pólos de horticultura (Anajatíua e Pedreiras, ambas em São Luís); Projeto Mandioca; Projeto Cabrita; Projeto Flores Tropicais; Projeto Patos Paissandu; Projeto Plantas Medicinais; Programa de Capacitação Ambiental; Projeto de Apicultura; e Projeto Casa Familiar Rural. A Casa Familiar Rural é um projeto que surge 02 anos depois da origem do CINPRA.
} 
Secretário de Agricultura e decidida pelo Conselho de Prefeitos; em seguida, era desenvolvido um evento de sensibilização convidando a maior quantidade de atores interessados e garantindo a presença dos secretários de agricultura e de produtores rurais. Para realização deste evento, o CINPRA convidava técnicos altamente capacitados para ministrarem o "curso" de sensibilização; em seguida, os municípios que resolviam abraçar o projeto recebiam orientações práticas e desenvolviam atividades práticas com o apoio dos parceiros do CINPRA. Cada fase do processo era amplamente divulgada na imprensa ${ }^{45}$.

Este modo de realização dos projetos ampliava a rede de relações dos membros do CINPRA e aumentava o sentimento de pertencimento à rede daqueles municípios e produtores que recebiam o curso e que participavam dos eventos.

Como o propósito era de incluir, cada vez mais, produtores e municípios, e havia a necessidade objetiva de garantir legitimidade para a implantação e fortalecimento do CINPRA, não se excluía sequer os municípios que não estavam em dia com a mensalidade, de tal modo que no final das contas só pagava mesmo quem, ao longo do processo fôra convencido da importância do projeto e estava comprometido com o CINPRA.

Ao mesmo tempo, a realização do evento e a continuidade do projeto garantiam a legitimidade não só junto aos beneficiados (produtores e prefeitos), mas também junto aos executores dos $\operatorname{cursos}^{46}$. Os técnicos da Embrapa

45 Esta seqüência descrita acima foi percebida principalmente quando, ao longo do desenvolvimento desta pesquisa, fomos ler os jornais de circulação no Estado e os recortes de jornais arquivados na sede do CINPRA.

${ }^{46}$ Os cursos e as atividades desenvolvidas pelo CINPRA contavam sempre com a participação de órgãos técnicos e universidades. Formalmente, o CINPRA, geralmente, celebrava convênios com as mais diversas instituições para executar suas ações. Esse procedimento garantia o bom desempenho da atividade e, ao mesmo tempo, legitimava o CINPRA para além do público específico para quem o evento era realizado. Dentre as parcerias destacam-se: Centro Nacional de Pesquisas de Hortaliças da Embrapa-Hortaliças com sede em Brasília (DF); Centro de Pesquisa Agroindustrial Tropical da Embrapa, com sede em Fortaleza e Pacajus (CE); Centro de Estudos da Mandioca da Embrapa Meio Norte com sede em Teresina (PI) e Embrapa Cruz das Almas (BA); Centro de Pesquisa em Caprinos da Embrapa-Caprinos, Sobral (CE); Centro de Raízes e Amidos Tropicais (Cerat) da Universidade Estadual Paulista (Unesp). 
passaram a visitar regularmente os municípios consorciados. Assim, o CINPRA foi constituindo uma rede também fora do Estado do Maranhão.

Deve-se ressaltar neste aspecto que os técnicos da EMBRAPA compunham o que Kingdon (2003) chamou de comunidade epistemológica ou comunidade técnica, comunidade na qual as soluções e alternativas aos problemas de políticas públicas são elaboradas. Estes técnicos participaram ativamente de vários momentos da formação do CINPRA, desde a elaboração do diagnóstico que gerou o problema público relacionado ao abastecimento e à produção de alimentos nos municípios maranhenses. Estes técnicos foram parceiros de todas as horas e foram fundamentais para a disseminação da idéia junto a outros municípios e outros Estados. Deve-se salientar ainda que esta Comunidade técnica teve papel relevante, ao longo do processo de implantação e fortalecimento do CINPRA, uma vez que sempre que foram chamados a participar na condição de parceiros do CINPRA estiveram presentes, seja ministrando cursos, seja prestando consultorias.

A ampla divulgação dos projetos na imprensa fazia que o CINPRA fosse difundido permanentemente. Ainda que não estivessem nas capas dos periódicos, as matérias sobre o CINPRA eram, geralmente de $1 / 4$ de página; vez ou outra de meia página; nesta fase inicial (dois primeiros anos), raramente tinha "chamada" na capa dos periódicos.

No final das contas, cada projeto resultava, na pior das hipóteses, em uma "Unidade Didática" que demonstrava a possibilidade real de realização do projeto e da melhoria da produção. Do ponto de vista simbólico, esse modo de operar os projetos, garantia a continuidade e o fortalecimento da idéia e sua disseminação não só no Maranhão, mas em outros estados também.

O "modus operandi" do CINPRA amplia sua rede social, bem como a rede social do empreendedor político (Léo Costa), da pequena burocracia que foi constituída no CINPRA, e de cada município membro dessa organização. 


\section{Consolidação do CINPRA}

O CINPRA, em 1999, era um projeto em pleno desenvolvimento. Por meio de depoimentos coletados ao longo da pesquisa, foi possível observar que tanto o "problema" da agricultura em São Luís; quanto as soluções propostas para a resolução do referido problema foram propostas e o processo de formulação foram "encabeçadas" por Léo Costa.

Ao longo deste tempo, desde a formulação, passando pela implementação do Consórcio (1997) e pelo desenvolvimento dos projetos, até o ano de 1999, quando este já estava estruturado e reconhecido pela imprensa, qual foi o papel exercido pelo Prefeito de São Luís, Jackson Lago?

O empenho de Jackson Lago na trabalho político de convencimento de outros prefeitos e liderança foi baixo. Sua presença nas ações do CINPRA se resumia à participação em abertura de eventos e inaugurações de alguma vitrine tecnológica.

Segundo depoimentos de Marco Aurélio (assessor técnico do CINPRA) e Léo Costa foram vários os "almoços" e "jantares" nos quais o tema do CINPRA fôra tratado com o prefeito.

Deste modo, o que se observa é que o CINPRA existia, mas ainda não era um tema forte na agenda de decisão dos prefeitos, sequer do prefeito do município pólo. Diferentemente disso, o tema tinha grande ressonância dentre os técnicos.

O tema do Consórcio da forma como foi apresentado foi ganhando adeptos em todas as camadas, inclusive nos meios de comunicação.

O que faltava então para "dar o salto", ou seja, para o tema dos Consórcios ganhar proeminência na agenda de decisão dos governos?

Faltava o que Kingdon (2003) chamou de "clima político" favorável. Este clima político torna-se favorável quando do reconhecimento externo do CINPRA, que legitimava sua ação e garantia maior visibilidade junto à opinião pública. 
Este reconhecimento veio com a premiação nacional no concurso de práticas inovadoras na Gestão Pública, realizado pelo Programa Gestão Pública e Cidadania da Fundação Getúlio Vargas (PGPC/FGV). Nas palavras de Léo Costa:

"Foi dureza conquistar Dr. Jackson com relação a idéia do consórcio. Agora quando a experiência foi premiada pela FGV ele ficou mais sensível à idéia do Consórcio. Aí ele aprimorou seu comportamento mesmo quando ia em reuniões do Consórcio. E passou a perceber que aquele projeto poderia ser apresentado em outras regiões. Ele teria o que dizer em outras regiões. Tanto assim que o Consórcio passou a ser um componente indispensável do discurso do Prefeito".

A partir de então (final de 1999), o prefeito decidiu espalhar a idéia e aprimorar as ações.

Para disseminar a idéia há, por um lado, um fato (a premiação); e um diagnóstico revisto.

É interessante perceber que o diagnóstico que, vai aos poucos, justificando a necessidade dos Consórcios, se aprimora com o tempo.

Inicialmente, o argumento era o do cinturão verde em torno de São Luís. A partir de 2000 , soma-se ao argumento inicial um argumento mais pertinente aos municípios do interior: o argumento de que nos municípios do Maranhão, a capacidade de realização de compras é maior que a capacidade de oferta de produtos, porque tanto a produção quanto a produtividade e a diversificação de produtos é baixa. Então, investir na formulação de políticas públicas que melhore os fatores produtivos é fundamental para a melhoria do desempenho econômico dos municípios. Como investimentos relacionados à transferência de tecnologia e ao apoio técnico são custosos, a organização de um consórcio pode gerar ganhos de escala.

Com a reeleição de Jackson Lago à frente da Prefeitura de São Luís, em 2000, e o início da nova gestão em 2001, o CINPRA se fortalece ${ }^{47}$.

${ }^{47}$ O Tema do CINPRA esteve pouco presente no discurso da reeleição, porque não era um tema que sensibilizava o eleitor médio. Apesar disso, em 2002 foi tema central da campanha de Jackson Lago para governador. Segundo Domingos, secretário executivo do CINPRA-COCAIS, as 
Em 2001, o CINPRA, para sensibilizar prefeitos do Estado do Maranhão, não mais apenas do entorno da capital, fortalece, no discurso, a idéia da municipalização da agricultura, articulando-a com a formação dos Consórcios como organizações capazes de juntar os prefeitos, tornando-os mais fortes numa eventual negociação com o Estado e, ao mesmo tempo, garantindo-lhes ganhos de escala visto que a participação em algum Consórcio Intermunicipal gera redução de custos.

Assim, o novo discurso em torno do CINPRA busca sensibilizar os prefeitos dos municípios maranhenses demonstrando-lhes que é possível realizar ações no setor da agricultura por meio da união de municípios.

Jackson Lago começa a usar a idéia dos Consórcios Intermunicipais para reunir prefeitos em todo estado do Maranhão. Era o início de sua campanha para o Governo do Estado.

Independentemente da motivação do então prefeito de São Luís, o fato é que ao viajar pelo Estado do Maranhão, Jackson Lago disseminava a idéia do CINPRA: surgem outros CINPRA's no Maranhão, estimulados por São Luís; além da veiculação da idéia da formação de uma rede de Consórcios ${ }^{48}$.

A estratégia adotada nesta ocasião foi a da realização de encontros de cidades por meio dos quais os prefeitos reeleitos e com experiências interessantes mostravam suas experiências para os prefeitos novos. Foram realizados 12 encontros de cidades.

A própria assessoria do Prefeito Jackson Lago preparava o encontro. Entrava em contato com o prefeito da cidade pólo. O discurso adotado junto aos prefeitos era o de que o prefeito Jackson Lago estava propondo essa atividade e

campanhas de Jackson Lago para Governador teve como principais bandeiras a "cooperação intermunicipal" e a "municipalização.

${ }^{48}$ Consórcio Intermunicipal do Centro Sul do Maranhão, composto por oito municípios e tendo Barra do Corda como município-sede; Consórcio Intermunicipal dos Cocais e Médio Parnaíba Maranhense, também composto por oito municípios, e sediado em Timon; Consórcio Intermunicipal do Médio Mearim, composto por dez mu $n$ nicípios, e sediado em Pedreiras; e Consórcio Intermunicipal dos Vales do Pindaré e do Grajaú, com sede no município de Santa Inês, e composto por uma totalidade de oito municípios. 
gostaria que o evento fosse um espaço para troca de experiências e de informações ${ }^{49}$.

Nessa ocasião, a maior parte dos prefeitos era do PFL, e ainda assim aceitavam participar do evento proposto por um Prefeito do PDT. A quebra de resistência era decorrente de um fato do passado e outro do presente.

O fato do passado era que a líder do PFL no Estado, governadora Roseana Sarney não havia feito oposição a Jackson Lago em sua reeleição para a Prefeitura de São Luís, porque não quisera se vincular a uma eventual derrota de seu partido na capital do Estado.

O fato do presente é que Jackson Lago vinculou o evento à idéia de "práticas inovadoras" e convidava outros prefeitos a participarem como expositores: apresentavam-se idéias relacionadas ao orçamento participativo, dentre outras. Para o evento eram convidados também o Ministério Público e o Tribunal de Contas para dar orientação jurídica aos prefeitos.

A realização do "Encontro de Cidades" mostrava que a completa ausência do Poder Executivo Estadual, era uma grande oportunidade a ser aproveitada pelo prefeito Jackson Lago que, naquele momento, queria se tornar conhecido no interior do Estado.

Em 2002, entra no discurso do então prefeito de São Luís a idéia da "Educação para Jovens do Campo".

O CINPRA se consolida como organização quando, por um lado, demonstra "capacidade de realização"; e por outro, dissemina a idéia do consórcio em torno da produção e do abastecimento em sua região específica, nas outras regiões do Maranhão, e em outros Estados. Fundamental neste processo foi a premiação e o reconhecimento da experiência por uma instituição de produção de conhecimento na área de gestão pública (FGV) com apoio do BNDES e da Fundação Ford.

Percebe-se que essa consolidação ocorre por meio da ampliação da rede de contatos e relações dos técnicos do CINPRA e principalmente de seu

\footnotetext{
${ }^{49}$ Interessante esclarecer que em 2000 o PDT elegeu apenas 05 prefeitos no Maranhão. Portanto, a ação não poderia ser circunscrita aos interesses partidários do Prefeito de São Luís.
} 
Secretário Executivo junto a outros técnicos da área rural, a secretários de agricultura, a órgãos técnicos de outros estados.

O convencimento e o envolvimento do Prefeito da cidade pólo do CINPRA e capital do Estado do Maranhão, Jackson Lago, cumpre papel específico na disseminação da experiência junto a outras cidades e mesmo junto a outros Estados.

Percebe-se então que o empreendedor político era evidentemente Léo Costa. Jackson Lago simplesmente aproveita a idéia do Consórcio para expandir seus horizontes eleitorais e de quebra auxilia na disseminação da idéia junto aos demais prefeitos do Maranhão.

\section{Conclusão}

O caso do CINPRA é emblemático no sentido de trazer elementos para a reflexão acerca do processo de formação dos consórcios intermunicipais por diversos motivos.

Destacam-se, ainda que não sejam em ordem de importância, os seguintes motivos:

- O CINPRA foi formado em um Estado que, em princípio não tem tradição "associativa" ou "cooperativa", como é o caso de estados como Santa Catarina, por exempo (Jacobi, 2006). Ainda assim foi possível observar a longa trajetória da constituição do CINPRA. Deste modo, diferente do que se pode pensar, a tradição associativista nem sempre é uma pré-condição; mas pelo contrário, pode ser formada ao longo do tempo. Ainda não é possível medir esse tipo de mudança de comportamento político local. No entanto, é fato que mesmo sem a tradição foi possível criar um Consórcio Intermunicipal, o que exigiu a identificação de interesses comuns entre os municípios que o compuseram; e a criação de uma relação de confiança entre os dirigentes municipais em torno da nova organização (CINPRA).

- A indução foi muito mais por meio do discurso que propriamente pelo ganho 
de benefício imediato. Ainda que sejam perceptíveis os ganhos aferidos por meio do que Léo Costa chama de "vitrines tecnológicas", isso não representa ganho imediato a cada município consorciado. Ainda assim, os municípios participaram da formação dos consórcios.

- Por meio do CINPRA é possível identificar um "empreendedor político" paciente. Léo Costa, no princípio, percebeu a oportunidade quando da necessidade e da mal sucedida tentativa de articular os municípios em torno de uma Região Metropolitana. Paralelamente a isto, foi constituindo um discurso em torno do qual seria possível mobilizar os interesses dos Prefeitos e de um setor técnico relacionado aos governos municipais e estaduais. Em seguida teve a paciência de pouco a pouco ir sensibilizando o Prefeito de São Luís da importância do CINPRA, ou seja, de deslocar o CINPRA para a chamada agenda de governo (lista de temas sobre a qual os políticos no governo prestam atenção e pode ser formada em decorrência do reconhecimento de algum problema ou em decorrência do grau de visibilidade que pode ser gerado ou ainda por vontade política isolada).

- Finalmente, a premiação do CINPRA pelo Programa Gestão Pública e Cidadania (PGPC) cumpriu importante papel na medida em que serviu de "janela de oportunidade" para deslocar o CINPRA da agenda de governo para a agenda de decisão (lista de temas que está sendo encaminhada para uma decisão efetiva a ser tomada pelo governo). Essa agenda decorre da conjunção dos três fluxos.

- Deve-se chamar atenção, finalmente, que o CINPRA entrou para a agenda de decisões do governo, contribuiu para levar uma série de idéias para além do "Estreito dos Mosquitos"; mas nem por isso, foi efetivo a ponto de reverter a situação rural do Estado do Maranhão ou de São Luís.

\section{Quadro 03}


Municípios participantes do Cinpra e os partidos políticos de seus respectivos prefeitos

\begin{tabular}{|l|c|c|}
\hline \multirow{2}{*}{\multicolumn{1}{|c|}{ Municípios }} & \multicolumn{3}{|c|}{ Partido do Prefeito } \\
\cline { 2 - 3 } & $\mathbf{1 9 9 7 - 2 0 0 0}$ & $\mathbf{2 0 0 1 - 2 0 0 4}$ \\
\hline Anapurus & PSD & PFL \\
\hline Axixá & PMDB & PTB \\
\hline Cantanhede & PMDB & PMDB \\
\hline Chapadinha & - & PFL \\
\hline Coroatá & PSB & - \\
\hline $\begin{array}{l}\text { Humberto de } \\
\text { Campos }\end{array}$ & PFL & PFL \\
\hline Icatu & & \\
\hline Matões do Norte & PFL & PTB \\
\hline Morros & PFL & PFL \\
\hline Pirapemas & PPB & PFL \\
\hline $\begin{array}{l}\text { Presidente } \\
\text { Juscelino }\end{array}$ & PFL & PFL \\
\hline Rosário & PSL & PTB \\
\hline Santa Inês & PFL & - \\
\hline São João Batista & PMDB & PMDB \\
\hline São Luis & PDT & PDT \\
\hline Santa Rita & - & PSDB \\
\hline Viana & PT & PT \\
\hline Vitória do Mearim & PFL & PMDB \\
\hline
\end{tabular}


Fonte: BARBOZA (1999). 


\section{Capítulo 4:}

\section{O Aparato Institucional para a Cooperação Intermunicipal no ABC Paulista}

\section{Introdução}

Este capítulo busca responder à pergunta de como surgem os consórcios intermunicipais a partir de um estudo específico: Consórcio Intermunicipal e outras instâncias regionais do Grande ABC Paulista.

A hipótese trabalhada neste estudo é a de que os consórcios (e o Consórcio do $A B C$ ) surgem pela combinação de um conjunto de fatores delineados do ponto de vista teórico por três abordagens: abordagem da escolha racional, do capital social e formação de agenda.

A abordagem da escolha racional, segundo a qual a cooperação entre municípios expressa por meio da formação do consórcio, decorre de uma indução externa ao território; a abordagem do capital social diz que a cooperação entre municípios é produto, por um lado, de uma cultura e de um acúmulo histórico que tendem ao trabalho cooperativo, e por outro, por uma rede de relações previamente constituídas. Neste segundo aspecto, busca-se saber então que redes são estas e que atores estão envolvidos com ela.

A terceira vertente é analítica é composta pelo que se convencionou chamar de teoria da formação de agendas de governo.

Para a análise deste caso (Grande $A B C$ ), o capítulo está estruturado em seis seções: esta introdução; a seção que fala da história da Região do Grande $A B C$; a seção que descreve as transformações econômicas regionais ao longo dos anos 90, período no qual nascem as instâncias regionais; a seção que explica a estrutura de cada instância regional do Grande $A B C$, quais sejam - o Consórcio Intermunicipal, o Fórum da Cidadania, a Câmara Regional e a Agência de

Desenvolvimento; a seção que trata da formação de agenda na região; e, finalmente, a seção das considerações finais. 


\section{Histórico}

A Região do Grande $A B C$ nasceu com a Vila de Santo André da Borda do Campo, fundada em 1553. No século XIX, o município de Santo André tinha a dimensão de praticamente toda a Região do $A B C$ de hoje. No século $X X$, os municípios foram se desmembrando e a Região do Grande $A B C$ foi se consolidando. Ela é formada por sete municípios: Santo André, São Bernardo do Campo, São Caetano do Sul, Diadema, Mauá, Ribeirão Pires e Rio Grande da Serra ${ }^{50}$.

Com um total de 2.350.065 habitantes ${ }^{51}$, a Região do Grande ABC representa o centro econômico mais dinâmico da Região Metropolitana de São Paulo (formada por 39 municípios). Como a região contempla parte da Estrada de Ferro Santos-Jundiaí (de São Paulo à Vila de Paranapiacaba), a atividade industrial foi a base do seu crescimento e desenvolvimento. Ainda na primeira metade do século $X X$, as primeiras indústrias (têxteis e pequenas oficinas) se instalaram no ABC. A Rhodia se instalou em Santo André em 1919 e a General Motors, em São Caetano do Sul em 1926. Os anos 30, período da II Guerra Mundial, foram marcados pela expansão da indústria metal-mecânica.

\footnotetext{
${ }^{50}$ A Vila de Santo André da Borda do Campo mudou de nome em 1812, passando a chamar Freguesia de São Bernardo (que se transformou em Município de São Bernardo em 1889). Em 1938, seu nome passou a ser Santo André (e sua sede passou da Vila de São Bernardo para o Distrito de Santo André). O distrito de São Bernardo (que compreendia também Diadema) se emancipou em 1944; São Caetano do Sul, em 1948; Mauá e Ribeirão Pires, em 1953; e Rio Grande da Serra, em 1958.

${ }^{51}$ Os municípios da Região do Grande ABC possuem 2.350.065 habitantes, divididos da seguinte forma: Santo André: 648.443; São Bernardo do Campo: 701.289; São Caetano do Sul: 140.144; Diadema: 356.389; Mauá: 363.112; Ribeirão Pires: 104.336; e Rio Grande da Serra: 36.352. Fonte: IBGE 2000.
} 
Figura 4

Localização da Região do Grande ABC

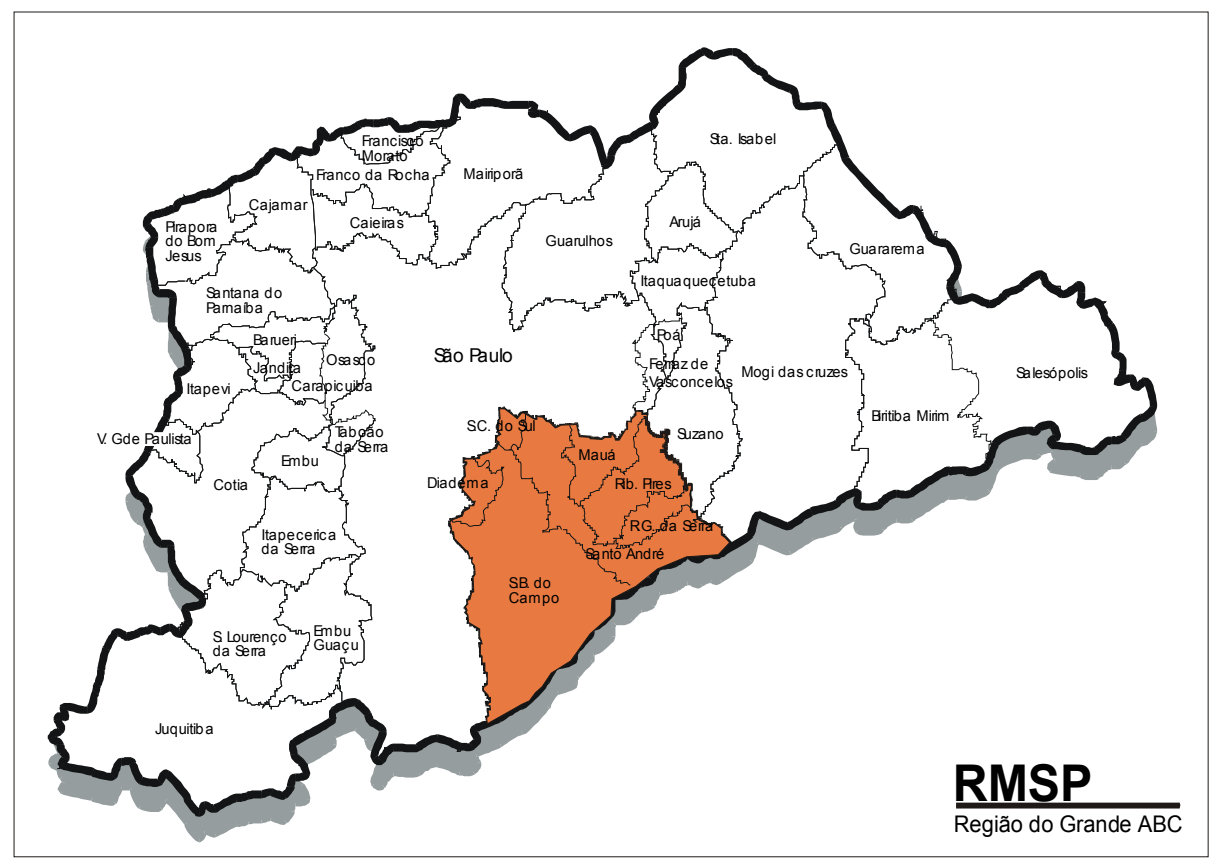

Com a inauguração da Via Anchieta, rodovia que liga a Capital a Santos, no início dos anos $50^{52}$, o eixo de desenvolvimento da região passou, de Santo André para São Bernardo do Campo. Foi na década de 1950, que a indústria automotiva (montadoras) se instalaram, principalmente em São Bernardo. No entanto, em Santo André, a indústria de autopeças cresceu e expandiu nesse período.

Em 1954, com a construção da Refinaria de Capuava (Recap), nasceu o Pólo Petroquímico de Capuava, que se consolidou em 1972. Hoje, são 14 empresas que fazem parte do Pólo e produzem derivados de petróleo. O Pólo Petroquímico de Capuava está localizado nos municípios de Santo André e de Mauá.

A pista ascendente foi inaugurada em abril de 1947 e a segunda pista, em 1953. A Via Anchieta (com 58 viadutos, 18 pontes e cinco túneis) passou a constituir-se um dos mais importantes corredores de exportação. http://209.85.165.104/search?q=cache:dkdMSmG00dwJ:www.estradas.com.br/histrod_anchieta.ht m+anchieta+hist\%C3\%B3ria\&hl=pt-BR\&ct=clnk\&cd=10\&gl=br, em 12 de junho de 2007.
} 


\section{Anos 90}

Para analisar as alterações instituições que buscaram induzir uma ação cooperada regional, uma das características fortes da Região do Grande ABC que deve ser considerada é a sua sociedade civil com um alto índice de organização (Klink, 2007), percebidas tanto nas organizações sindicais quanto nas organizações pastorais da Igreja Católica. Esta organização da sociedade local é fator relevante para a construção da identidade regional e para legitimar as ações de governo pactuadas com a própria sociedade civil.

A região também é caracterizada pela baixa qualidade do espaço público, uso e ocupação do solo desordenado, relação de fiscalização frágil quanto à utilização da água e da região de mananciais. Além disso, pode-se acrescentar a essa "baixa urbanidade" uma relativa ausência de alternativas de cultura e lazer, o que sempre fez com que a região se considerasse mais uma região periférica, girando em torno da grande capital (Jeroen, 2004).

Ainda do ponto de vista da urbanização, deve-se considerar que a região do Grande $A B C$ é intensamente "conurbada", ou seja, constituída de cidades que formam uma seqüência, fortemente adensadas em suas franjas, de modo que ficam grudadas umas as outras, e ainda assim, mantêm suas autonomias.

Em meio a essas características, os anos 80 e, mais intensamente os anos 90, foram marcados por uma crise industrial, o que gerou fechamento ou transferência para outras regiões de unidades produtivas, perda do dinamismo de alguns setores, diminuição do volume de emprego e queda do rendimento médio da população da Região do Grande ABC.

É fato de que o setor terciário (comércio e serviços) expandiu na Região do Grande $A B C$ a partir da década de 80 . No entanto, o processo de retração industrial foi maior que o crescimento do comércio e dos serviços. Ou seja, embora a Região do Grande ABC apresente indicadores econômicos favoráveis (Abrucio e Sorares, 2001: 137), a crise atingiu a economia da Região do Grande $A B C$, gerando impactos negativos. 
"O ABC terminou a década de 70 como uma das regiões mais industrializadas e ricas do país. A partir daí começou a perder participação no cenário nacional com a desaceleração do crescimento industrial, a perda absoluta da riqueza e aumento exacerbado do desemprego e das ocupações informais resultantes de mudanças na conjuntura econômica internacional e internacional" (ABRUCIO e SOARES, 2001. P. 138).

Deste modo, estão apresentadas duas situações que embora possam ser mais intensas no Grande $A B C$, assolam outras regiões do país também:

- A situação dos grandes aglomerados urbanos com impactos negativos sobre a questão ambiental, principalmente sobre a coleta e disposição final de resíduos sólidos; bem como os impactos sobre o uso racional e sustentável dos mananciais;

- A situação da "desindustrialização" com impactos negativos sobre a geração de renda e de empregos. Neste caso especificamente, embora a questão seja de ordem nacional, e produzida principalmente pelas opções de política macroeconômica, o impacto é sentido no território (nas instituições locais, população e espaço geográfico).

No $A B C$, entretanto, as situações descritas, foram encaradas como problemas a serem enfrentados pelo poder público. Dado que os problemas "transpassam" o município, o enfrentamento dos mesmos precisa de ferramentas para além das instituições municipais, seja para sua resolução efetiva, seja para organizar o território e promover o diálogo com outras instâncias, como governo estadual e governo federal.

A formulação da situação como problema foi realizada por Celso Daniel ${ }^{53}$, a partir da encomenda de estudos e da leitura e interpretação da vasta bibliografia que se produzia sobre a região.

\footnotetext{
${ }^{53}$ Não podemos esquecer que Celso Daniel atuava em diversos campos: no campo político, no qual havia, até 2000, encarado duas eleições: a de 1982 e a de 1988, tendo perdido a primeira e ganho a segunda. Paralelamente a atuação política, o engenheiro Celso Daniel também exercia o magistério: era professor na EAESP-FGV. Então, trata-se de um prefeito que transitava tanto no meio político quanto no meio acadêmico.
} 
No entanto, a situação regional só seria encarada como problema regional se assim fosse encarada pelos atores políticos da região. Daniel então inicia um processo de convencimento dos prefeitos da região sobre os problemas regionais que deveriam ser enfrentados conjuntamente.

O cenário político favorecia o início do processo, dado que municípios grandes da região eram governados por prefeitos de um mesmo partido ${ }^{54}$, com tradição na região: o Partido dos Trabalhadores (PT).

Então, agora, é preciso caracterizar a Região do $A B C$ do ponto de vista dos instrumentos institucionais relativos à cooperação regional, tais como região metropolitana e consórcios intermunicipais.

O cenário nacional foi de um grande vácuo institucional no que diz respeito ao trato da questão metropolitana. O governo federal delegou a questão metropolitana para a esfera estadual ${ }^{55}$, que por sua vez, no caso do Estado de 54

Neste período, os municípios da Região do Grande ABC tinham os seguintes prefeitos: Santo André (Celso Daniel/PT); Diadema (José Augusto da Silva Ramos/PT); Ribeirão Pires (Luiz Carlos Grecco/PDS); São Bernardo do Campo (Maurício Soares/PT); São Caetano do Sul (Luiz Olinto Tortorello/PTB); Rio Grande da Serra (Aparecido Franco/PTB); e Mauá (Amaury Fioravanti/PL).

55 As Regiões Metropolitanas (RMs) destacam-se pelo seu gigantismo, com alto índice de população urbana, de industrialização, comércio e também de violência, pobreza e desemprego. Segundo Maricato, em entrevista cedida ao jornal Em Questão, em 13 de agosto de 2004, "Por RM entende-se uma ocupação urbana contínua, que ultrapassa os limites físicos dos municípios". No entanto, as instituições criadas para gerir as RMs não foram capazes de resolver os problemas destas áreas. As primeiras RMs, no Brasil, foram criadas ainda no regime militar, por meio da Lei Complementar $n^{\circ} 14 / 73$. Municípios localizados no entorno de oito capitais de Estado foram compulsoriamente unidos em Regiões Metropolitanas. Em 1974, foi criada a Região Metropolitana do Rio de Janeiro (Lei Complementar n²0/74). As atribuições legais das RMs estão diretamente relacionadas com os problemas genéricos e potenciais das referidas regiões, dentre os quais: planejamento integrado do desenvolvimento econômico e social; saneamento básico; uso do solo metropolitano; transporte e sistema viário; produção e distribuição de gás combustível canalizado; aproveitamento dos recursos hídricos e controle da poluição ambiental; e outros serviços definidos por lei federal. Com a Constituição de 1988, os estados passaram a assumir a competência pela institucionalização de suas unidades regionais. Além das RMs, admitiu-se a formação de aglomerações urbanas e microrregiões, como categorias de organização regional. "Essa faculdade, além de abrir a possibilidade de alteração dos limites das RMs existentes, incluindo ou mesmo excluindo municípios, desencadeou um contínuo ciclo de institucionalizações de novas unidades regionais, quase sempre classificadas como metropolitanas." (MOURA et al, 2004:36). Hoje, são 26 as RMs, sendo nove delas instituídas por lei federal (e criadas no ano de 1973, com exceção da RM do Rio de Janeiro, criada em 1974) e 17, instituídas por leis estaduais (criadas entre 1995 e 2003). A sua maioria está localizada nas regiões Sul (dez RMs), Sudeste (sete RMs) e Nordeste (sete RMs), enquanto as regiões Centro-Oeste e Norte possuem apenas uma, cada. A questão crucial do debate sobre as RMs é justamente a criação de mecanismos de cooperação entre os seus municípios. Souza (2003) explicita bem a falta de cooperação entre entes governamentais no 
São Paulo, não conseguiu mobilizar os atores diretamente relacionados com a questão, como prefeituras e Câmaras Municipais das Regiões Metropolitanas.

Ainda assim, a Região do $A B C$ como sub-região da área metropolitana mobilizou-se para tratar de problemas regionais de forma regional, e não de forma autárquica, município a município, como fora padrão no Brasil.

Quais foram os elementos essenciais para superar a fragmentação da ação, o "hobbesianismo" municipal, a ação individual frente aos problemas regionais?

O cenário favorável na região: durante o mandato de 1989 a 1992, época do surgimento do Consórcio Intermunicipal do Grande ABC, o PT governou em três dos quatro maiores municípios da Região (Santo André, São Bernardo do Campo e Diadema); a presença de um prefeito que cumpriu o papel de formular o problema, propor uma alternativa de resposta, e buscar o entendimento com os demais prefeitos para que isso acontecesse; a existência de uma identidade regional forte arraigada nas pessoas e nos atores políticos regionais.

De um modo sintético, segundo Abrucio e Soares (2001: p. 128 e 129), a identidade regional do Grande $A B C$ se constituiu pelos seguintes fatores:

- História: até metade do século XX, a Região do Grande era apenas um município;

- Geografia: como mais da metade do território da região do Grande ABC é área de mananciais, essa questão torna-se comum aos seus municípios;

\footnotetext{
Brasil e o porque das RMs não terem revertido este quadro nos últimos anos. Segundo a autora, a Constituição Federal brasileira de 1988 e a maioria das Constituições Estaduais não abordaram o arranjo jurídico e administrativo de territórios que vão além dos limites territoriais dos municípios. Alguns fatores explicam esta distância do tema. Em primeiro lugar, as RMs foram criadas oficialmente durante a vigência do governo militar, e suas instâncias formais herdaram um caráter centralizador e autoritário de gestão sem nenhum incentivo para a cooperação entre o estado e os municípios ou entre os municípios. Em segundo lugar, em resposta a um passado onde os municípios deviam se subordinar ao governo federal, os municípios, na década de 80 , priorizaram a conquista à sua autonomia decisória e financeira, sem se incomodar com a cooperação entre as diferentes esferas de governo. A competição eleitoral, com a volta das eleições diretas, intensificou ainda mais a competição por recursos, indo na contramão da cooperação e da partilha desses. E, finalmente, a Constituição de 1988, ao delegar, em termos relativos, mais recursos para os municípios do que para os estados, estimulou os estados a não se preocuparem com a gestão das RMs (Souza, 2003).
} 
- Economia: o desenvolvimento industrial (décadas de 60 e 70 ) e a sua crise (décadas de 80 e 90);

- Fator social e político: os movimentos sociais, o novo sindicalismo e o nascimento do Partido dos Trabalhadores (anos 70 e 80);

- Cultura: sentimento de pertencimento à Região do Grande ABC.

Dada a situação e o problema formulado, qual foi a alternativa proposta? A formação de um Consórcio Intermunicipal que desde o início foi "multifacetado" em termos de problemas a serem enfrentados até como forma de construir uma agenda que conciliasse os interesses de todos os prefeitos da região.

Assim, desde a formação do Consórcio, passando pelo Fórum da Cidadania, a Câmara Regional e a Agência de Desenvolvimento, vários atores se envolveram no processo - atores diferentes, em períodos diferentes, com instituições diferentes.

A seguir, busco descrever a formação deste complexo institucional, ressaltando a presença dos atores envolvidos.

\section{Instâncias Regionais do Grande ABC}

Chamamos de instâncias regionais do Grande $A B C$, três instituições que propõem ações regionais, ou seja, extrapolam os limites municipais; e foram criadas ao longo dos anos 90, tendo como motes a identidade regional e a cooperação intermunicipal.

Estas instituições foram criadas a partir da iniciativa de atores sociais e políticos diversos, mas todas elas tiveram a presença ativa do ex-prefeito de Santo André, Celso Daniel.

As instituições a que nos referimos são:

- Consórcio Intermunicipal das Bacias do Alto Tamanduateí e Billings;

- Fórum da Cidadania do Grande ABC;

- Câmara Regional do Grande ABC e Agência de Desenvolvimento 


\section{i. Consórcio Intermunicipal das Bacias do Alto Tamanduateí e Billings}

O caso da Região do Grande ABC é interessante para ser analisado, pois seus arranjos institucionais não se limitam à constituição de um Consórcio Intermunicipal (das Bacias do Alto Tamanduateí e Billings). Ele é o primeiro a surgir, é bem verdade, mas ao longo do processo de cooperação entre os sete municípios do $A B C$, nasceram outras instâncias: Fórum da Cidadania, Câmara Regional do Grande ABC e Agência de Desenvolvimento Econômico do Grande $A B C$.

O Consórcio Intermunicipal das Bacias do Alto Tamanduateí e Billings foi constituído em 19 de dezembro de 1990, representando os sete municípios do Grande $A B C$ em matérias de interesse comum. O custeio do Consórcio se dá por meio de cota de contribuição fixada pelo Conselho de Municípios de acordo com o princípio da proporcionalidade, com base nas receitas correntes do exercício anterior de cada Município ${ }^{56}$.

Já em sua criação, a perspectiva do Consórcio era a de ampliar a sua atuação para temas que fossem além da gestão de recursos hídricos, visando também o desenvolvimento econômico local. No entanto, seus primeiros trabalhos giraram em torno de tema do meio ambiente: resíduos sólidos (de 1990 a 1992), lei de recursos hídricos (1993) e área de mananciais (de 1993 a 1995).

A diversidade de tema é relevante, porque de algum modo, alguns dos temas tratados pelo Consórcio constituíram-se nos temas que formaram os "embriões" de outras instituições regionais.

O primeiro período do Consórcio (1991-1992) foi fundamental para que a imprensa e a opinião pública fossem se apropriando do tema. Dentre as realizações objetivas, buscou-se, no primeiro período, atuar nos fóruns estaduais que tratavam dos temas ambientais (e especificamente dos temas de mananciais)

\footnotetext{
${ }_{56}$ Tanto o financiamento quanto a estrutura organizacional não se diferencia muito do que se observa em outros Consórcios. No caso do Grande ABC, a organização do Consórcio é formada por um Conselho de Municípios, Conselho Fiscal, do Conselho Consultivo e da Secretaria Executiva. O Presidente do Consórcio (um prefeito eleito entre seus pares) escolhe um assessor jurídico e um assessor executivo de sua confiança para comporem a Secretaria Executiva.
} 
e a partir disso encaminhar propostas e projetos para o Governo do Estado de São Paulo57; além disso, buscou-se um acordo entre os prefeitos para evitar a Guerra Fiscal, o que, por um lado, não implicava em investimentos; e por outro, em termos simbólicos, indicava para a imprensa de grande circulação nacional que o Grande $A B C$ estava enfrentando seus problemas econômicos por meio da cooperação entre municípios ${ }^{58}$.

O primeiro período, portanto, foi fundamental para colocar o tema da cooperação intermunicipal na pauta dos governos da região e estruturar a organização de tal modo que, com uma burocracia mínima, passava a se constituir em um novo ator, com interesses e tarefas específicas.

No segundo período (1993-1996), há uma forte alteração na composição do quadro político regional e, com isso, dos objetivos e interesses do Consórcio. Neste período o Consórcio volta-se quase que exclusivamente para sua organização interna ${ }^{59}$.

O período seguinte (1997-2000) pode ser considerado o "apogeu" do Consórcio. Nesta ocasião, há o retorno de dois prefeitos que aturaram juntos na primeira fase: Celso Daniel e Maurício Soares. Há também mudança Governo do Estado (1995-1998), que se mostra disposto a tratar da questão regional com o Consórcio, enquanto ator político.

\footnotetext{
57

Nesta ocasião, o Governador do Estado de São Paulo, Luís Antonio Fleury Filho, não era sensível às questões regionais. Aliás, todo projeto de regionalização desenvolvido pelo Governo Montoro fora perdido ao longo dos governos que o sucederam: Quércia (1987-1990) e Fleury (1991-1994).

${ }^{58}$ É bem verdade que dada a fragilidade institucional dos órgãos de cooperação entre municípios no Brasil, não há mecanismos de sansões para aqueles prefeitos que resolvem "boicotar" a ação combinada. Assim, neste caso específico, o Prefeito de São Caetano do Sul, simplesmente não cumpriu o acordo. Ainda assim, a ação conjunta dos municípios foi veiculada pela imprensa como bem sucedida.

59

Neste período, os municípios da Região do Grande $A B C$ tinham os seguintes prefeitos: Santo André (Newton da Costa Brandão/PTB); Diadema (José de Filippi Júnior/PT); Ribeirão Pires (Valdírio Prisco/PMDB); São Bernardo do Campo (Walter Demarchi/PTB); São Caetano do Sul (Antonio Dall'Anese/PTB); Rio Grande da Serra (José da Cruz Jardim Teixeira/PSDB); e Mauá (José Carlos Grecco/PMDB).
} 
A mudança do cenário político, portanto, cria condição para que o tema da cooperação e as ações em torno do Consórcio ganhem novo fôlego. Evidentemente, não é só a mudança do cenário, mas também o deslocamento de personagens como o prefeito de Santo André, Celso Daniel, para o centro do cenário regional.

Neste período, o tema dos resíduos sólidos voltou a ser tratado como problema regional; foram feitos propostas e encaminhamentos reais visando um acordo com os municípios da região e o governo do Estado para a questão de "macrodrenagem" e para a construção de reservatórios de contenção de enchentes.

O prefeito Maurício Soares propôs a formação do "movimento: criança prioridade absoluta" para atender, regionalmente, "meninos de rua".

Em 1998, o Secretário de Ciência e Tecnologia do Estado de São Paulo, Emerson Kapaz, propôs aos prefeitos da região a criação de um Pólo Tecnológico no Grande $A B C^{60}$.

Além disso, a Fundação SEADE foi contratada para elaborar uma Pesquisa de Atividade Econômica específica para a região; entrou na pauta de discussão regional o combate à violência contra a mulher, dentre outros.

A partir de 2001, pode-se dizer que o Consórcio entra numa fase de decadência. Do ponto de vista da realização de ações, da realização de reuniões, da manutenção da legitimidade encontrada no passado, da manutenção e ampliação dos parceiros envolvidos com os projetos regionais.

Em 2001, morre Mario Covas, parceiro estadual do Consórcio e responsável pelo aporte de um volume representativo de recursos a serem gastos na região, por meio das instituições regionais. Em 2002, Celso Daniel é assassinado.

\footnotetext{
${ }^{60}$ Para esta proposta que foi desenvolvida mais amplamente na Câmara Regional, caberia às prefeituras o financiamento dos terrenos, construções, transportes e suplementação de recursos para o pagamento de professores.
} 
Apesar da existência de atores, do capital social regional, da tradição em organização setorial em torno de temas específicos, o empreendedor político regional, responsável pelo convencimento inicial dos prefeitos de seu partido a participarem de uma iniciativa dessa envergadura que é o consórcio, do convencimento dos atores da sociedade civil de se envolverem nos temas regionais e de aproximação do governo do Estado, perde o parceiro estadual em 2001 e é assassinado em 2002.

\section{ii. Fórum da Cidadania do Grande ABC}

O Fórum da Cidadania do Grande ABC é criado em 1995, exatamente no período de refluxo do Consórcio. Parece paradoxal: como o tema da cooperação, ao mesmo tempo, ganhava e perdia força? Como o tema era transferido de uma organização (Consórcio) para outra com grau de informalidade muito grande (Fórum da Cidadania)?

Em 1993, Celso Daniel não elege seu sucessor em Santo André. Paralelamente a isso, como foi visto, o quadro político regional altera-se intensamente.

Entre 1993 e 1994, período em que não exerceu cargo eletivo, Celso Daniel, para manter na agenda local, ainda que não mais por meio da ação governamental ${ }^{61}$, o tema da cooperação regional, trata de articular com atores da sociedade civil, o Fórum da Cidadania do Grande ABC.

\footnotetext{
${ }^{61}$ COBB, Roger; ROSS, Jennie-Keith; ROSS, Marc Howard (1970), mostram que a introdução de determinado tema na agenda do governo poder ser feita por iniciativa do próprio governo (este é o foco adotado por Kingdon, 1985), ou pela sociedade civil, desde que essa consiga mobilizar em torno de seus propósitos os formadores de opinião, a comunidade de "conhecedores" do tema e, assim, produzam fatos políticos suficientes para chamar atenção do governo, quem de fato, pode introduzir problemas em sua agenda com condição objetiva de resolvê-los.
} 
Em paralelo, Celso mantém suas atividades no PT e na academia, mantendo, portanto, proximidade com diferentes atores sociais e políticos, importantes para a disputa e manutenção do poder em termos de disputas eleitorais (Partidos e Sindicatos) e em termos de fundamentação teórico e legitimação das ações (Universidade, Igreja, Sindicatos).

Celso Daniel disputa a eleição para Deputado Federal em 1994. É eleito e leva o tema do Consórcio para dentro da agenda da Câmara dos Deputados. No ABC, fruto da articulação iniciada em 1993, quando da existência do "Movimento Vote no Grande ABC" do qual Celso Daniel também se aproximou, o próprio Celso, articula e participa ativamente da fundação, em 16 de março de 1995, do Fórum da Cidadania do $A B C$, formado por associações de empresas, sindicatos de trabalhadores e organizações não governamentais (o Fórum da Cidadania chegou a contemplar mais de 100 instituições, em 1999).

A presença de Celso foi fundamental para aproximar os sindicatos dos empresários. Ao longo do processo de formação do Fórum, a aproximação dos atores diferentes foi ocorrendo aos poucos e lentamente.

Ao tratar da entrada de alguns atores junto ao Fórum, Abrucio e Soares (2001) afirmam que:

\begin{abstract}
"A entrada dos sindicatos só foi possível e se consolidou porque ficou cada vez mais claro que esse relacionamento se estabeleceria em função dos interesses compartilhados pelo conjunto da sociedade civil, que justificam uma agregação e ação destes setores, respeitando as eventuais divergências".
\end{abstract}

Com esta composição ampla e plural, entre 1997 e 1999, o Fórum funcionou como importante interlocutor da sociedade junto ao Consórcio, embora isso não tivesse ocorrido de maneira formal.

Com a constituição da Câmara Regional (1997), que contemplava atores da sociedade civil e do governo; e seu braço operacional - a Agência de Desenvolvimento - criado em 1998, o Fórum da Cidadania vai perdendo relevância. 
O Fórum, portanto, cumpriu um papel de manter a chama da idéia da cooperação regional e aproximou atores excluídos do Consórcio (por sua própria natureza e concepção). Pode-se dizer inclusive que o Fórum da Cidadania foi um bom experimento para a implementação da Câmara Regional do Grande ABC.

Para os propósitos deste trabalho, observa-se que a formação do Fórum da Cidadania foi o mecanismo encontrado por Celso Daniel para ampliar a articulação da sua rede em torno do tema e da idéia da articulação regional.

Ao mesmo tempo em que amplia sua rede, mantém o tema da articulação intermunicipal na agenda regional.

A fraqueza dos prefeitos que compunham o Consórcio em termos de perceber a relevância do tema (que já estava amparado e legitimado simbolicamente e por ações concretas) é elemento importante para explicar o fortalecimento do tema em torno de outra instituição - o Fórum da Cidadania.

\section{iii. Câmara Regional do Grande ABC e Agência de Desenvolvimento}

Com o novo ciclo político renovado pelas eleições de 1996, os novos prefeitos, a partir de $1997^{62}$, retomam as atividades do Consórcio Intermunicipal, fortalecendo ações e compromissos que não aqueles ligados ao meio ambiente.

Daí decorre, no que podemos chamar de um movimento sincronizado, o deslocamento do tema do Desenvolvimento Regional para uma outra arena política - a Câmara Regional. O tema do Desenvolvimento Regional estava latente tanto no período do Fórum da Cidadania quanto já no primeiro período de desenvolvimento do Consórcio. A idéia de uma instância mais informal de negociação ampliada para esferas do governo e da sociedade já tinham sido

\footnotetext{
${ }^{62}$ Os prefeitos da Região do Grande ABC eleitos para o mandato de 1997 a 2000 foram: Celso Daniel (PT), Santo André, Maurício Soares (agora no PSDB), São Bernardo do Campo, Luiz Tortorello (PTB), São Caetano do Sul, Gilson Menezes (PSB), Diadema, Oswaldo Dias (PT), Mauá, Maria Inês (PT), Ribeirão Pires e Cido Franco (PTB), Rio Grande da Serra. Este último faleceu durante o mandato, sendo que seu vice, José Carlos Assunção (PST) foi assassinado. Depois dele, assumiram a Prefeitura de Rio Grande da Serra durante esse mandato o Presidente da Câmara, Expedito de Oliveira (PST), Danilo Franco (novo Prefeito eleito pelo PTB) - que renunciou -, seu vice, Barros Carvalho (PTB) - que foi cassado - e Ramon Veslaquez (PT).
} 
testadas tanto no período em que o $\mathrm{ABC}$ havia experimentado a implantação da Câmara Setorial Automotivo (1991), quanto no período de instalação do Fórum da Cidadania (1995).

Com a retomada dos trabalhos do Consórcio Intermunicipal de forma mais intensa e com a experiência do Fórum da Cidadania, os prefeitos se uniram à sociedade civil e criaram a Câmara Regional do Grande ABC, em 12 de março de 1997, com a proposta de funcionar como um grande parlamento democrático de debates e acordos regionais. Além das Prefeituras, das entidades civis, empresariais e sindicatos de trabalhadores, fizeram parte da Câmara Regional o governo estadual e os parlamentares da região (nível federal, estadual e municipal).

A Câmara Regional teve como objetivo integrar a atuação do poder público à participação da sociedade civil buscando soluções comuns para os diversos problemas da região. O seu funcionamento se dava por meio de um conselho deliberativo, uma coordenação executiva e grupos temáticos. O conselho deliberativo era composto por 43 membros que se reuniam anualmente para assinatura dos acordos regionais. A coordenação executiva era formada por 25 membros indicados pelo conselho deliberativo, que se reuniam mensalmente para analisar, aprovar e encaminhar as ações propostas pelos grupos temáticos. Já os grupos temáticos lidavam com temas que remetem, de um modo ou outro, ao desenvolvimento da Região.

A Câmara trouxe para primeiro plano o tema do desenvolvimento econômico regional, considerando dimensões como emprego, meio ambiente e qualidade de vida (ABRUCIO e SOARES, 2001. P. 178 e 179). Nesse sentido, a criação da Agência de Desenvolvimento Econômico do Grande $A B C$ foi um dos resultados mais importantes de sua atuação.

A Câmara Regional, instância informal de negociação, que usou por algum tempo o Consórcio como braço operacional, teve suas ações pautadas num longo processo de planejamento estratégico regioal elaborado em 2000, com previsão de 10 anos. Esse planejamento foi construído e desenvolvido a partir de sete eixos 
estruturantes: (1) educação e tecnologia; (2) sustentabilidade das áreas de mananciais; (3) acessibilidade e infra-estrutura; (4) diversificação e fortalecimento das cadeias produtivas; (5) ambiente urbano de qualidade; (6) identidade regional e estruturas institucionais; e (7) inclusão social.

Outras ações importantes que tiveram impacto na Região do Grande ABC foram algumas obras de infra-estrutura voltadas para a melhoria do tráfego e combate às inundações, a formulação e execução de um plano de qualificação profissional (principalmente no setor plástico), a criação da Universidade Federal do Grande $A B C$, a formação de uma rede estruturada de pequenas e médias empresas complementar à grande indústria globalizada e a dinamização do setor terciário - principalmente turismo, lazer, entretenimento e cultura.

Para os propósitos deste trabalho, o relevante é saber quem foram os atores envolvidos na formatação inicial desta nova instituição e como isso ocorreu?

Segundo entrevista com Jeroen, o fundamental para a constituição do Fórum Regional foi a aproximação dos municípios da região com o governo do Estado de São Paulo.

A iniciativa foi do Governo Estadual que, por meio da Secretaria Estadual de Ciência, Tecnologia e Desenvolvimento Regional, comanda por Emerson Kapaz, concebeu o Fórum como mecanismo de fortalecimento das Regiões Metropolitanas.

Foi concebido como Fórum político informal, com participação dos deputados e Prefeitos da Região, vereadores e sociedade civil.

O braço operacional das decisões tomadas pelo Fórum era o Consórcio Intermunicipal. Dado que a Câmara havia ganhado peso e que os atores com ela envolvidos eram muito diversos e extrapolava o limite pensado inicialmente pelo Consórcio que, até aquele momento, era o braço operacional da Câmara, começou a se veicular a idéia da criação de uma Agência de Desenvolvimento. 
A Agência de Desenvolvimento Econômico do Grande $A B C$, criada em 27 de outubro de 1998, é fruto da Câmara Regional do Grande ABC. A Agência é uma OSCIP, foi criada para otimizar os trabalhos da Câmara Regional e oferece suporte técnico ao processo de modernização e fomento empresarial da Região do Grande ABC. 49\% das ações da Agência são do Poder Público (Consórcio Intermunicipal do Grande $A B C)$ e $51 \%$, da sociedade civil - associações comerciais do $A B C, C I E S P s$ do $A B C$, sindicatos de trabalhadores do $A B C$, SEBRAE, empresas do Pólo Petroquímico de Capuava e universidades da região.

O seu principal objetivo é promover o desenvolvimento econômico sustentável da região por meio da criação e manutenção de Banco de Dados socioeconômicos, fomento do "Marketing Regional" e criação de um fundo de apoio e financiamento de pequenas e médias empresas da Região. Na realidade, os principais projetos desenvolvidos pela Agência hoje em dia são os Arranjos Produtivos Locais, o Centro de Informação e Apoio à Tecnologia do Plástico e as Incubadoras de Empresas.

O Projeto dos Arranjos Produtivos Locais foi criado em agosto de 2004, em parceria com o SEBRAE de São Paulo, que fornece apoio técnico e financeiro. $O$ objetivo do projeto é capacitar e estimular o crescimento de médias, pequenas e microempresas dos setores de plástico, ferramentaria e autopeças, instaladas nos sete municípios da Região do Grande ABC.

O Centro de Informação e Apoio ao Plástico - CIAP - teve início em setembro de 2005 a partir de demandas do APL de Plásticos e seus parceiros são a Fundação Santo André, o Instituto de Pesquisas Tecnológicas (IPT), da USP e Finep (Governo Federal). Seu objetivo é fortalecer a vocação industrial da região no setor plástico por meio do apoio ao desenvolvimento tecnológico de pequenas e médias empresas do setor. 
A Agência apóia ainda duas incubadoras de empresas da Região do Grande ABC: Incubadora de Empresas Barão de Mauá, criada em 2001, em parceria com SEBRAE de São Paulo e Prefeitura de Mauá, e In.Nova Incubadora Tecnológica de Santo André, criada em 2002, em parceria com SEBRAE de São Paulo e a Prefeitura de Santo André.

Atualmente, a arena de maior disputa regional e maior visibilidade e consideração aos olhos da sociedade política do $A B C$ é a Agência de Desenvolvimento.

\section{Conclusão}

Afinal, por que surgem as instâncias regionais no Grande ABC? Esta seção busca resgatar a análise feita até agora e ampará-la de forma mais sistematizada sob a orientação das teorias articuladas com as três vertentes neoinstitucionalistas que foram discutidas em capítulos anteriores: escolha racional, capital social e formação de agenda.

A criação das instituições de cooperação regional do $A B C$ não prescindiu, no que tange ao processo de convencimento dos atores envolvidos, de uma análise de custo benefício da ação que seria empreendida. Assim, a análise racional foi elemento importante para o processo de convencimento. Formulado o problema e encontrada uma alternativa para sua resolução, há que se convencer os demais atores envolvidos com a região, ou seja, os prefeitos e os municípios, de que a ação coletiva em torno de uma nova institucionalidade compensa.

A relação de custo benefício como argumento no processo de convencimento foi favorável, não só para criar o Consórcio, como também para mantê-lo - principalmente no período de 1993 a 1996, quando os prefeitos não priorizaram a ação regional.

Nesses termos, Abrucio e Soares explicam que:

“(...) muitos dos atores locais, pouco a pouco, tomando uma postura de organizar-se regionalmente, constituindo uma ação coletiva contra a crise. 
Ressalte-se que nem todos os grupos atuaram na mesma intensidade (...), bem como nem todas as questões tiveram o mesmo potencial agregador. De todo o modo, as dificuldades econômicas colocaram grande parte da região sob um dilema: ou se reagia coletivamente, ou se corria o risco de todos perderem, em proporções diferentes, porém com um impacto de soma-negativa no geral" (ABRUCIO e SOARES, 2001. P. 152).

Deve-se considerar ainda que ao longo do processo, em sua primeira fase, a criação do Consórcio com a formação de uma pequena burocracia interna e com o "espraiamento" da idéia da cooperação e da ação regional, formou um novo ator político (o próprio consórcio) com uma pequena rede em torno de si.

Paralelo ao processo de convencimento e ao uso e percepção da racionalidade no que tange ao empreendimento de uma ação coletiva, há que se considerar na análise do complexo processo de formação do conjunto de instituições no $A B C$ o fator cultural da região e a identidade regional construída ao longo do tempo.

A partir dessas considerações, há quem diga (autores mais propensos às análises culturalistas ou em identificar capital social nos processos cooperativos) que a cooperação entre municípios no $A B C$ é produto, por um lado, de uma cultura e de um acúmulo histórico que tendem ao trabalho cooperativo, e por outro, por uma rede de relações previamente constituídas.

Evidentemente, a identidade regional, sob várias dimensões - econômica, histórica, cultural, social e política - sempre foi forte no Grande ABC, e indicam, de alguma forma, um acúmulo histórico em termos de cooperação dos atores, pelo menos em setores específicos (que acabam por garantir certa identidade regional). Como exemplos dessa "tradição", citam-se a atuação forte das comunidades eclesiais de base da Igreja Católica (principalmente a partir da década de 70), do movimento sindical e, também, de associações comerciais e industriais (ABRUCIO e SOARES, 2001; DANIEL, 2001).

Evidentemente que esse fator contribuiu para propiciar cooperação. Ao mesmo tempo, deve-se considerar entretanto que as arenas de participação dos 
diversos atores, seus interesses, suas concepções de mundo, são diferentes e essa diferença fazia com que muitos deles atuassem em arenas diferentes, de tal modo que a participação e a cooperação pode ser observada como ação intergrupo, e não necessariamente entre grupos.

Assim, a tradição regional é importante, mais importante talvez tenha sido o sentimento de pertencimento desses atores e a identidade regional como "cimento" para dar liga a articulação regional. Ainda assim, a articulação propriamente dita não é fruto automático dessa tradição, de tal modo, que há necessidade de explorar outros fatores para buscar uma explicação mais plausível ao fenômeno da cooperação regional no Grande ABC.

A idéia de formação de agendas de governo, no sentido de buscar elementos explicativos para o complexo processo de formação das instituições de cooperação regional no $A B C$, é plausível.

A abordagem utilizada aqui é aquela proposta por Kingdon (1985), segundo a qual a introdução de determinado tema na agenda dos governos é dada pela confluência de três fluxos interdependentes.

O primeiro fluxo busca entender como determinada situação transforma-se em problema passível de deter a atenção do governo.

Com relação ao primeiro fluxo, o que se observa é a formulação de pelo menos dois problemas que se desdobram. O primeiro, da baixa urbanidade, que se desdobrou em dois outros: o de problema ambiental, que do ponto de vista dos atores envolvidos com o processo de constituição do Consórcio seria encarado mais como um problema de investimentos em infra-estrutura; e o problema da baixa urbanidade em termos da escassez de equipamentos públicos regionais que, neste caso, sim, há uma relação direta com o setor de infra-estrutura propriamente dita.

Outra situação regional enunciada como problema é a que diz respeito ao desenvolvimento econômico. 
Deste modo, percebe-se então que a identidade regional e todo o "capital social" existente poderiam ser canalizados para o enfretamento conjunto dos problemas que os atores regionais reconheciam como comum (os dois enunciados acima).

As soluções e alternativas para a resolução do problema são as "ações coletivas regionais" por meio da criação de uma organização regional. Em princípio foi o Consórcio, articulado no setor de bacias hidrográficas.

Por que articulado por meio deste setor, se o tema ambiental em termos gerais não era o mais convincente?

Por que, a ação regional por meio de bacias estava mais amplamente amparada em legislações e porque havia recursos do Fundo de Bacias Hidrográficas que poderiam ser acionados.

Desde o início, entretanto, os temas tratados pelo consórcio eram mais abrangentes que os específicos da questão hídrica. Este em si não era capaz de sensibilizar e mobilizar os atores políticos regionais.

Então, estavam formulado o problema e indicada a alternativa de solução. A quem cabia a decisão política e seria o "empreendedor político" responsável pelo convencimento dos outros atores e da introdução do problema e de sua solução na agenda regional?

No caso do Grande $A B C$, os atores políticos eram os prefeitos. $O$ empreendedor político que encabeça a formulação do problema, e é a figura presente tanto na execução quanto no processo de convencimento é Celso Daniel.

Na primeira fase de implantação do Consórcio, Celso Daniel contava com o cenário político favorável, com a presença de três dos sete prefeitos sendo do PT.

Depois, dado o novo quadro político regional (condicionante de suas ações), com apenas um prefeito petista, Celso Daniel fortalece o "Movimento Vote no $A B C " e$, em seguida, cria o Fórum da Cidadania, com outros atores (empresários e sindicatos, por meio de suas organizações; dentre outros). Nesta 
fase, portanto, condicionado pela conjuntura, Celso Daniel, estrutura outra arena, a partir de atores já existentes e da experiência prévia, para fortalecer a idéia da ação regional. Nesta fase, dada a entrada de novos atores, entram também novos interesses, e se reconfigura a agenda, com ênfase ainda maior na questão do Desenvolvimento Econômico.

O retorno de Celso à Prefeitura de Santo André com outros três prefeitos petistas nas prefeituras da região e Maurício Soares (ex-petista eleito pelo PSDB), o Consórcio se fortalece novamente.

No entanto, os atores envolvidos com o Fórum não têm assento no Consórcio, restrito aos prefeitos.

Daí, mantêm-se o Fórum, até que um novo ator (o governo do Estado de São Paulo) propõe a formação de uma Câmara de Desenvolvimento.

A Câmara, finalmente, cria as condições para a formação da Agência de Desenvolvimento, braço operacional do referido Fórum.

Percebe-se, portanto, resumidamente, que para o caso do $A B C$ os argumentos de custo e benefício em termos de ação regional foram importantes, mas não foram essenciais para a formação de uma organização regional. Somado a isso, o fator cultural e a inserção de novos atores (e, portanto, a expansão da rede de articulação em torno dos temas regionais) aumentavam abrangência temática do Consórcio, dando origem a outras organizações.

No entanto, a construção dos argumentos, a identificação dos atores, o processo de convencimento dos atores dependia de um "empreendedor político" (Celso Daniel), evidentemente com apoios importantes ao longo do processo (como foi o apoio de Mauricio Soares e de Mario Covas).

A morte de Celso e o enfraquecimento das organizações regionais parecem que estão diretamente relacionados.

A manutenção das instituições, por outro lado, corrobora o argumento da escolha racional de que a manutenção por inércia das instituições constituídas é menos custoso que seu fechamento. Deve-se considerar neste caso, o surgimento 
de uma pequena burocracia em torno do Consórcio e das instituições bem como o acúmulo simbólico da experiência impregnado na região, como elementos que ajudam na manutenção das organizações existentes. 


\section{Capítulo 5:}

Os Consórcios Intermunicipais de Saúde de Minas Gerais

\section{Introdução}

O tema dos Consórcios Intermunicipais de Saúde bem como dos Consórcios em Minas Gerais foram intensamente estudados em Lima e Pastrana (2000a), Lima e Pastrana (2000b) e Rocha e Faria (2004).

Este capítulo se respalda tanto nos estudos acima citados quanto em entrevistas realizadas com o Doutor Rafael Guerra, ex-diretor da Faculdade de Ciências Médicas de Minas Gerais, um dos articuladores dos prineiros Consórcios Intermunicipais de Saúde (CIS) em Minas Gerais, ex-secretário estadual de Saúde de Minas Gerais, e atual Deputado Federal (PSDB-MG).

O objetivo deste capítulo é reconstituir a formação histórica dos primeiros CIS-MG, buscando identificar os atores envolvidos com sua constituição, bem como os mecanismos utilizados ao longo do processo de formação dos referidos CIS-MG e de disseminação dos CIS pelo estado mineiro.

No caso dos CIS-MG, houve alguma indução externa ao território que estimulou a criação de 70 CIS até o ano de 1999? E se sim, que indução foi essa? Além do estímulo externo, objetivou-se aqui levantar quais eram as redes de relações previamente constituídas e que atores estavam envolvidos nas regiões onde os primeiros CIS se instalaram? 
Para os propósitos desta pesquisa, também se buscou fazer um estudo sobre a formação de agendas de governos, considerando a abordagem dada por Kingdon (1985) que contempla a confluência de três fluxos interdependentes: (1) como determinada situação transforma-se em problema passível de deter a atenção do governo; (2) como respostas e alternativas a determinados problemas são desenvolvidos por técnicos e comunidades de gestores de políticas públicas; e (3) quem e como, do ponto de vista político, define que problemas são relevantes e que soluções são pertinentes. A junção dos três fluxos ocorre em dado momento chamado de janela de oportunidade e é feita pela presença e perspicácia do empreendedor político.

Diferentemente dos outros estudos de caso abordados nesta pesquisa, este caso diz respeito à criação de diversos CIS em um Estado ao longo de determinado período. Em Minas Gerais, minha hipótese é de que o ex-Diretor da Faculdade de Ciências Médicas e, mais tarde, Secretário de Saúde do Estado, Rafael Guerra ${ }^{63}$ foi o empreendedor político, que soube convencer os atores locais e criar ferramentas para a criação de Consórcios Intermunicipais de Saúde.

E, mais uma vez, diferentemente dos outros estudos de caso abordados neste trabalho, o caso mineiro teve como empreendedor político uma pessoa de fora das microrregiões envolvidas. Em um primeiro momento, Rafael Guerra exercia o papel de Diretor de uma Faculdade de Ciências Médicas e estava interessado em como potencializar o trabalho de seus alunos e, em um segundo momento, era o responsável pela pasta de saúde do Estado e estava interessado na formulação de uma política pública estadual, a partir da organização dos municípios em CIS.

No primeiro momento, quando Guerra era o Diretor da Faculdade de Ciências Médicas e teve a iniciativa de criação de CIS, cumpriu apenas papel de formulador de política pública. No entanto, ao se tornar Secretário de Saúde do

${ }^{63}$ Rafael Guerra foi, inicialmente (1992), diretor da Faculdade de Ciências Médicas de Minas Gerais que iniciou o processo de CIS no Estado mineiro; em seguida, Secretário de Saúde do Estado de Minas Gerais; e finalmente Deputado Federal, responsável pela apresentação de um Projeto de Lei que buscou regular o funcionamento dos Consórcios Intermunicipais no país. 
Estado, além de formulador de política pública, exerceu também o papel de político. Vale reforçar que Guerra é Deputado federal pelo Estado de Minas Gerais e está em seu terceiro mandato. Entre suas ações enquanto parlamentar, pode-se destacar a sua proposta de lei para criação de Consórcios Intermunicipais Públicos, que serviu de base (assim como outra proposta de lei do atual Governo federal) para a atual Lei 11.107, de 06 de abril de 2005.

Este capítulo está organizado em três seções, além desta introdução e das conclusões.

\section{Os Consórcios de Saúde em Minas Gerais}

De acordo com o IBGE (2001), havia no Brasil, em 2001, 1969 municípios envolvidos com Consórcios Intermunicipais de Saúde (CIS). Não houve setor que mobilizou maior número de municípios que o setor saúde. Esse envolvimento ocorreu de forma homogênea em todos os Estados?

Não. Observou-se que o maior número de municípios envolvidos com os CIS ocorreu em Minas Gerais (688 dos 853 municípios). Em termos percentuais, este número só foi menor que os Estados do Paraná (87\%) e Espírito Santo (85\%). Nesta época já havia ocorrido um "refluxo" de consorciamento em Minas Gerais. O pico de municípios consorciados em MG ocorreu no período 1995-1998 (exatamente no período em que Rafael Guerra foi Secretário Estadual de Saúde).

Dada a intensidade de consorciamento de municípios ao longo do período 1995-1998, pretende-se nas próximas seções verificar a gênese desse processo, ainda na época em que Rafael Guerra era Diretor da Faculdade de Ciências Médicas de Minas Gerais, o detalhamento dos primeiros Consórcios, e sua expansão.

\section{O Consórcio Intermunicipal de Saúde do Alto São Franciso (CISASF)}

O primeiro Consórcio Intermunicipal de Saúde (CIS) de Minas Gerais (MG), no período recente, surgiu em 1993, no pequeno município de Moema (6.500 
habitantes), na região do Alto São Francisco, e recebeu o nome de CIS do Alto São Francisco ${ }^{64}$.

A origem remota deste Consórcio é o programa "Internato Rural", concebido pelo Diretor da Faculdade de Ciências Médicas de Minas Gerais, Rafael Guerra, em 1989. O Programa consistia em fazer com que os alunos do quinto ano do curso de Medicina passassem dois meses e meio fixos em uma cidade do interior. O "estágio", na ocasião, era realizado em dupla.

Segundo Relatório de Pesquisa da Fundação João Pinheiro (FJP, 1996):

"O processo de criação deste Consórcio iniciou-se com a reforma curricular da Faculdade de Ciências Médicas, que implementou ao final dos anos 80 um novo modelo de docência, com o objetivo de resgatar o papel social da Universidade. Professores e alunos prestariam assistência à população do interior do Estado, propiciando a resolução da maior parte de seus problemas de saúde, num processo de reorientação da formação do médico generalista".

Para cada dupla de alunos que se deslocava para o interior, havia uma supervisão exercida por um professor: clínica, pediatria, ginecologia e cirurgia. A supervisão se revezava. Como Minas Gerais é muito grande, procurou-se formar "núcleos". O primeiro núcleo foi formado no Alto São Francisco. A realização da supervisão dependia do bom entendimento com o prefeito do município ${ }^{65}$. projeto, na verdade, dependia do Poder Público.

\footnotetext{
${ }^{64}$ A Ata de instalação do Consórcio Intermunicipal de Saúde dos Municípios da Microrregião do Alto São Francisco (CISASF) foi assinada em outubro de 1993 pelos prefeitos de 14 municípios: Araújos, Bom Despacho, Igaratinga, Iguatama, Martinho Campos, Moema, Nova Serrana, Perdigão, Pedra do Indaiá, Lagoa da Prata, Leandro Ferreira, Santo Antonio do Monte, Luz e Japaraíba. Também assinaram a Ata de instalação do CISASF o Secretário de Estado da Saúde, o Diretor da Faculdade de Ciências Médicas de Minas Gerais, o Presidente da Associação Microrregional dos Municípios do Alto São Francisco (AMASF), vereadores, representantes da sociedade civil, da imprensa, dentre outros.

${ }^{65}$ A primeira tentativa de constituição de núcleo foi feita na Região do Vale do Jequitinhonha, região mais pobre de Minas Gerais. No entanto, por falta de entendimento com o Poder Público Local, não se constituiu o Núcleo de "Internato Rural".
} 
No caso da Região do Alto São Francisco, deve-se considerar que nessa região havia um hospital localizado no município de Moema. O hospital estava pronto e fechado porque não tinha médico e tampouco recursos municipais para financiar o seu funcionamento.

Nas palavras de Alves (1995), o hospital nasceu de um erro de planejamento:

"a mulher do Dr. José Agenor, hoje [1995] coordenador do Projeto Nordeste do Ministério da Saúde, nasceu em Moema, município de 6.500 habitantes, no Alto São Francisco, em Minas Gerais. Usando seus conhecimentos na Organização Pan-Americana de Saúde (OPAS), Agenor conseguiu recursos para lá construir um pequeno hospital. Depois de pronto, o prefeito descobriu não ter nem médicos, nem dinheiro, nem doentes suficientes para manter o hospital".

O hospital tinha mobiliário, equipamento, instrumental cirúrgico, vestuário, mas não tinha recursos para custear sua manutenção. O prefeito do município de Moema, sabendo do Programa "Internato Rural", procurou o então Diretor da Faculdade de Ciências Médicas, Rafael Guerra.

A Faculdade, por sua vez, tinha profissionais qualificados em diversas especialidades médicas que representavam parte significativa do custo de manutenção de qualquer hospital. Então Guerra aceitou o desafio e a oportunidade e adotou o hospital como referência para o "Internato Rural", disponibilizando, professores e, em seguida, residentes de medicina geral e comunitária.

A Prefeitura de Moema, por sua vez, por meio de repasses de recursos do SUS (Governo Federal e Gvoerno Estadual), conseguia financiar parte do custo operacional do Hospital (aquisição de material de consumo, dentre outros).

O bom resultado da parceria implicou no aumento da demanda por atendimentos. Moema tornou-se referência regional em assunto de Saúde. O hospital passou a atender pacientes de vários municípios da região, o que significava aumento da quantidade de trabalho e, por conseguinte, do custo de manutenção do hospital. O prefeito de Moema não tinha recursos adicionais para 
aplicar no hospital e o diretor da Faculdade de Ciências Médicas não achava correto usar os recursos provenientes das mensalidades pagas pelos alunos no custeio do hospital.

Diante do impasse, Guerra (então diretora da Faculdade) começou a pensar na possibilidade da formação do que viria a se chamar Consórcio Intermunicipal de Saúde do Alto São Francisco (CISASF).

Do ponto de vista do que chamamos de formação de agenda dos governos, o caso relatado nos indica a transformação de duas situações específicas em dois problemas, quais sejam, insuficiência de recursos financeiros (públicos) para 0 provimento de serviços hospitalares por parte da Prefeitura de Moema; e a ação fragmentada e isolada dos municípios para o enfrentamento de problemas comuns a eles ${ }^{66}$.

Diante do reconhecimento dos atores em cena, dos recursos existentes e da situação publicamente reconhecida como problema, o que fazer?

Em outros termos, há um problema típico de ação coletiva, segundo o qual os atores em jogo dispõem de recursos para a resolução de um problema comum, mas falta coordenação e confiança entre os atores para a implementação de uma ação conjunta. Assim, diante de tal fato, o que fazer?

Uma alternativa para a resolução do problema seria a constituição de um consórcio setorial, na área de saúde.

Mas não se tinha conhecimento de como formar um Consórcio. Em entrevista, Rafael Guerra revela que só havia ouvido falar de um Consórcio (precedente) em funcionamento, no município de Penápolis (SP). Além disso, tomara conhecimento, por intermédio de um ex-aluno, da existência de Consórcios Intermunicipais italianos na área de geração e transmissão de energia elétrica.

\footnotetext{
${ }_{66}$ A ação isolada e fragmentada dos municípios anteriormente a formação do CISASF é reconhecida pelas lideranças e pelos prefeitos locais. Em outras palavras, seus relatos expressos no Relatório de Pesquisa da Fundação João Pinheiro (FSP, 1996), reconhecem que a ação dos prefeitos era geralmente deslocar os pacientes de um município para outro, por meio de ambulâncias. Não se resolvia o problema do paciente e, além disso, se transferia a responsabilidade da assistência pública à saúde para outro município.
} 
Então, procurou se aprofundar no conhecimento das referidas experiências, com apoio da assessoria jurídica da Faculdade, e adaptar as idéias para o caso prático do Alto São Francisco.

Assim, Guerra desenvolveu um Modelo de Consórcio Intermunicipal de Saúde (CIS), por meio do qual cada prefeitura, ao aderir ao CIS, repassaria $1 \%$ do seu Fundo de Participação dos Municípios (FPM) ${ }^{67}$.

Guerra, com o apoio do Prefeito de Moema e do Secretário de Saúde do município vizinho (município de Luz), procurou os prefeitos das cidades da região.

De acordo com a entrevista realizada com Rafael Guerra, neste processo de convencimento, houve o caso em que a Câmara Municipal de Lagoa da Prata resistiu à adesão de seu município à proposta do Consórcio. Dessa maneira, o próprio Rafael Guerra propôs-se a se reunir com os vereadores de Lagoa da Prata e imediatamente ampliou o convite a todos os vereadores dos municípios interessados para explicar o que era o CIS e como funcionaria, bem como as vantagens para cada município envolvido.

Realizada a audiência pública, os vereadores convenceram-se da importância deste tipo de ação coletiva. O jogo se inverteu. A partir de então, os vereadores passaram a pressionar os prefeitos para que aderissem rapidamente ao Consórcio.

As Câmaras Municipais, no caso específico do primeiro Consórcio Intermunicipal de Saúde de Minas Gerais, mostraram-se um ator político relevante.

De acordo com entrevistas realizadas por pesquisadores da Fundação João Pinheiro (FJP, 1996), dois anos depois da criação do CISASF, as dificuldades descritas pelos atores envolvidos com o Consórcio diziam respeito à falta de confiança entre os prefeitos, à falta de experiência em realizar ações conjuntas, à

\footnotetext{
${ }^{67}$ FPM é a sigla do Fundo de Participação dos Municípios composta por $22,5 \%$ do Imposto sobre Produtos Industrializados (IPI) e do Imposto de Renda (IR). Este fundo, constituído no âmbito do governo federal, é repassado para os municípios tendo a população como parâmetro distributivo. De acordo com as regras de distribuição do FPM, quanto maior o município, menor é o volume de recurso a ele repassado.
} 
prática de buscar soluções (ou falsas soluções) isoladas, e à falta de conhecimento por parte dos prefeitos do que era um Consórcio. Para o prefeito de Lagoa da Prata, a grande dificuldade dos prefeitos não era viabilizar o Consórcio e sim compreender o Consórcio (Relatório da Fundação João Pinheiro, 1996: 96).

Ainda segundo o relatório da Fundação João Pinheiro (FJP, 1996), outra dificuldade encontrada pelos prefeitos era relacionada às divergências partidárias:

"Alguns prefeitos consideravam que esta união de esforços poderia não dar certo por pertencerem a partidos diferentes" (Relatório da Fundação João Pinheiro, 1996: 96).

No processo de convencimento, Guerra, como ator externo ao jogo políticopartidário local, utilizou-se, primeiramente, dos bons resultados do serviço já prestado; em seguida da demonstração do baixo custo que cada município teria para manutenção do Consórcio (1\% do FPM) frente aos benefícios trazidos à política regional/municipal de saúde. De acordo com seus argumentos, a baixa adesão dos municípios implicaria no afastamento da Faculdade de Ciências Médicas da manutenção do hospital. A conseqüência seria a diminuição da qualidade do serviço de saúde prestado na região e a ineficiência na alocação dos vários recursos dispersos no território: recursos humanos, institucionais e financeiros.

Dessa forma, fica evidente o papel relevante de Guerra no processo de criação do CISASF. Ele teve a capacidade de identificar, organizar e sistematizar os problemas que os municípios da região estavam passando, quais sejam, o alto custo para os poderes públicos locais manterem serviço de saúde com qualidade, e a dependência de serviços médicos e serviços de saúde de outros municípios maiores (incluindo Belo Horizonte e São Paulo); e além disso, adaptou uma solução para o problema local e convenceu os atores políticos locais de quais eram os problemas identificados e de qual era a solução plausível.

O prefeito de Santo Antônio do Monte, por exemplo, em entrevista concedida a pesquisadores da Fundação João Pinheiro (1996), revelou que a adesão de seu município ao CISASF ocorreu porque, ele, na condição de prefeito, 
precisava "buscar soluções pra os problemas de saúde em [sua cidade], com agilidade e qualidade no atendimento, [por meio do] serviço prestado no Hospital Universitário".

Os prefeitos convenceram-se de que a ação coletiva seria proveitosa para cada um deles. Ainda assim o Consórcio começou a funcionar somente em 1993, no início com a adesão formal de 14 municípios e adesão real de apenas quatro municípios ${ }^{68}$. Os municípios cujos prefeitos assinaram a ata de instalação eram: Araújos, Bom Despacho, Igaratinga, Iguatama, Martinho Campos, Moema, Nova Serrana, Perdigão, Pedra do Indaiá, Lagoa da Prata, Leandro Ferreira, Santo Antônio do Monte, Luz e Japaraíba.

Uma vez formado o Consórcio, deve-se dizer que suas ações, desde sua formação, foram desenvolvidas de forma gradual e sempre com o devido cuidado para não afrouxar os laços de confiança que se buscava construir ao longo do processo:

\begin{abstract}
"A implementação das atividades assistenciais pelo Consórcio tem se dado de forma gradual, com enfoque parcial, mas com iniciativas no sentido de abranger a globalidade da capacidade instalada da rede microrregional de saúde, e diferenciada no que se refere aos instrumentos de formalização dos vínculos e ao establelecimento das contrapartidas".
\end{abstract}

Uma ação importante do Consórcio ocorrida em 1995, foi a absorção do Hospital Professor Basílio, localizado em Moema, pelo próprio Consórcio. Essa absorção ocorreu por meio de um Convênio Geral de Cooperação entre a Fundação Educacional Lucas Machado da Faculdade de Ciências Médicas de Minas Gerais (FELUMA), o Consórcio e a Prefeitura de Moema, segundo o qual Prefeitura de Moema, FELUMA e o Consórcio se co-responsabilizam pelo funcionamento e pela manutenção do Hospital.

Segundo o Convênio (FJP, 1996: 92-93):

- A Prefeitura Municipal de Moema cede "ao Consórcio, com a interveniência da FELUMA, em regime de comodato e através de instrumento próprio,

\footnotetext{
${ }^{68}$ O CIS do Alto São Francisco chegou a contemplar 25 municípios.
} 
pelo prazo de 30 anos, o imóvel constituído pleo 'Hospital Professor Basílio' e seu respectivo terreno com todo o seu material permanente, inclusive seus instrumentos, equipamentos, móveis e utensílios, linhas telefônicas, e veículos automotores", e, além disso, responsabiliza-se pelo financiamento de $50 \%$ das despesas de custeio da rede assistencial.

- O Consórcio, já constituído como pessoa jurídica, recebe "o imóvel, equipamentos, instrumentos, móveis e utensílios mencionados" no item acima, e gerencia "os serviços na área de saúde, médico ambulatorial e hospitalar à população dos municípios constituintes do Consórcio pelo mesmo prazo em que perdurar o comodato dos bens mencionados" e a arcar com $50 \%$ das despesas de custeio da rede assistencial.

- A Fundação Educacional Lucas Machado da Faculdade de Ciências Médicas de Minas Gerais (FELUMA) manterá o convênio com o Ministério de Educação e Cultura (MEC), Ministério de Previdência e Assistência Social (MPAS) e com o Sistema Único de Saúde (SUS), com a interveniência da Secretaria de Estado da Saúde e repassará para a conta corrente do Consórcio os repasses de recursos recebidos do SUS correspondentes ao faturamento do Hospital Universitário Professor Basílio ou quaisquer outros recebidos pelo Hospital.

Evidentemente, o município de Moema, por contribuir com mais recursos para o funcionamento do Hospital tinha atenção diferenciada com relação aos demais municípios.

No entanto, do ponto de vista político a concentração de serviços em um município poderia gerar atritos. Então, para que se organizasse o sistema de saúde regional de forma hierarquizada e minimamente racional em termos de alocação de recursos e estabelecimento das competências para a prestação dos serviços de atenção primária, secundária e terciária, foi estabelecido, em 1995, depois de uma revisão do Estatuto e do Regimento Interno do Consórcio, que:

- O nível de atenção primária - clínicas básicas e prevenção - ficaria sob a responsabilidade de cada município; 
- O nível de atenção secundária - especialidades, hospital de nível secundário e auxílio diagnóstico - ficaria sob a responsabilidade do Consórcio;

- O nível de atenção terciária - especialidades, hospital de nível terciário e auxílio diagnóstico - ficaria sob a responsabilidade do Consórcio, na medida em que o próprio Consórcio conseguisse dar conta das responsabilidades relativas à atenção de nível secundária.

Além da organização e da hierarquização das responsabilidades regionais no que diz respeito à política de saúde, as novas instalações de Núcleos e Institutos relacionados a especialidades secundárias foram feitas em diferentes municípios, de tal modo que todos os prefeitos e lideranças locais fossem se sentindo contemplados com o desenvolvimento das ações do Consórcio.

Assim, outros municípios instalaram em seus territórios equipamentos de saúde regional. É o caso, por exemplo, do município de Iguatama, onde funciona um Centro de Referência de Oftalmologia, cujo investimento foi feito pela Secretaria Estadual e pelo Ministério da Saúde. A articulação para a instalação do Centro contou com a fundamental participação da Faculdade de Ciências Médicas e dos prefeitos envolvidos. No caso de Iguatama, merece destaque a análise feita por Alves (2000: 18), segundo a qual:

"É evidente que uma cidadezinha de oito mil habitantes não teria nem necessidade, nem dinheiro, para manter o único centro de referência de oftalmologia de toda Minas Gerais fora de Belo Horizonte. A sua existência só foi possível porque Iguatama recebe os pacientes necessitados de tratamento dos olhos das outras 14 prefeituras que participam do consórcio de saúde da região e, sobrando leitos, do resto do estado também. Cada prefeitura repassa para Iguatama os recursos do SUS correspondente ao procedimento médico feito".

Outro município contemplado pela instalação de novos equipamentos foi Bom Despacho que recebeu um Posto de Atendimento/Emergência e Neurologia, financiado por meio de recursos do SUS Federal. 
No município de Santo Antonio do Monte, por sua vez, foi instalado o Instituto da Mulher, financiado com recursos do SUS Municipal.

E finalmente, o município de Lagoa da Prata foi contemplada com o Núcleo de Saúde Mental, também financiado com recursos do SUS Municipal.

O Consórcio, para o caso de todos estes Centros e Institutos, responsabilizou-se pela contratação da mão-de-obra.

Ao todo o CISASF tem um quadro funcional com 62 servidores, dos quais sete (07) alocados na Sede do Consórcio (município de Luz); 51 alocados no Hospital Universitário Professor Basílio (município de ); dois (02) alocados no Núcleo de Saúde Mental; e outros dois (02) alocados no Instituo da Mulher. Na Sede do CISASF funciona o sistema de agendamento de consultas do Consórcio. Tanto a sede quanto as Secretarias Municipais de Saúde dos municípios que compõem o Consórcio dispõem de equipamento de informática, adquiridos com recursos captados pelo próprio CISASF junto ao Ministério da Saúde. Do ponto de vista operacional, os recursos para o referido financiamento foram alocados na Fundação Lucas Machado.

Assim, o Consórcio Intermunicipal de Saúde do Alto São Francisco (CISASF) tornou-se a ponta da lança para a formação do Consórcio Intermunicipal de Saúde dos Municípios da Microrregião do Alto Rio Grande (CISMARG), e de tantos outros no Estado de Minas Gerias.

\section{O Consórcio Intermunicipal de Saúde dos Municípios da Microrregião do Alto Rio Grande (CISMARG)}

O segundo Consórcio Intermunicipal de Saúde constituído sob influência e trabalho do diretor da Faculdade de Ciências Médicas, Rafael Guerra, foi o CIS dos Municípios da Microrregião do Alto Rio Grande - CISMARG. A sua formação se deu de forma semelhante ao CIS do Alto São Francisco.

De acordo com Rocha e Faria (2004): 
"Em 1992, a direção da Faculdade de Ciências Médicas propõe uma parceria à prefeitura de Santo Antônio do Amparo para transformar a policlínica municipal ali existente em um hospital universitário. 0 objetivo nesse caso era criar condições para criação de vagas de residência médica destinadas aos seus alunos." (ROCHA e FARIA, 2004. P. 27).

Assim como Moema, o Hospital Universitário de Santo Antônio do Amparo começou a atender a população dos municípios vizinhos. Quando a Faculdade de Ciências Médicas, sob orientação e coordenação de seu diretor, Rafael Guerra, e o prefeito do município de Santo Antônio do Amparo propuseram aos outros prefeitos a formação de um Consórcio, a resistência logo apareceu.

"Porém, a realidade se impunha: a necessidade de sustentar a oferta dos serviços para a população da região demandava cooperação. Assim, em 1993 os prefeitos assinam um termo de intenções para a criação do CISMARG, que contava com 21 municípios consorciados" (ROCHA e FARIA, 2004. P. 27 e 28).

Os municípios participantes do CISMARG, quando da sua criação, eram: Aguanil, Bom Sucesso, Campo Belo, Candeias, Cana Verde, Carmópolis de Minas, Carrancas, Cristais, Ibituruna, ljací, Ingaí, Itumirim, Lavras, Luminárias, Nepomuceno, Oliveira, Perdões, Ribeirão Vermelho, Santana do Jacaré, Santo Antônio do Amparo e São Francisco de Paula.

O CISMARG funcionou nas instalações físicas e utilizou a estrutura de apoio administrativo da Associação Microrregional de Municípios do Alto Rio Grande - AMALG. Durante os anos de 1993 e 1994, as câmaras de vereadores dos municípios interessados aprovaram as leis municipais autorizativas.

Desde sua fundação, conforme estabelece 0 artigo $5^{\circ}$ do Estatuto do Consórcio, as finalidades do CISMARG são as seguintes (Relatório da Fundação João Pinheiro, FJP, 1996:71):

“I- representar o conjunto dos Municípios que o integram em assuntos de interesse comum, perante quaisquer outras entidades, especialmente perante as demais esferas constitucionais do governo; II- planejar, adotar e executar programas e medidas destinadas a promover e acelerar o desenvolvimento 
sócio-econômico da região compreendida no território dos Municípios consorciados, na medida em que se interfira nos fatores condicionantes e determinantes da saúde;

III- planejar, adotar e executar programas e medidas destinadas a promover a saúde dos habitantes da região e implantar os serviços afins."

O problema que deu origem ao CISMARG foi novamente um dilema de ação coletiva que culminou na incapacidade do Hospital Universitário de Santo Antônio do Amparo em atender toda a população que procurava seus serviços.

O Hospital Universitário de Santo Antônio do Amparo era procurado pela população de inúmeros municípios vizinhos que, muitas vezes, adotavam como política de saúde a compra de ambulância não propriamente para resolver os problemas de saúde da população local, mas para transferir a responsabilidade de garantir o acesso à saúde a municípios da região que possuíam algum tipo de atendimento hospitalar.

Para se ter uma idéia dessa situação em que o município transfere problema a outro, sem no entanto, remunerar pela transferência, é emblemático o caso do município de Campo Belo que chegou a criar uma linha de ônibus que ia de um município ao outro, tão grande era o fluxo de pacientes para o hospital.

Diante de tal situação:

"Numa tentativa de resolução, a Faculdade buscou aumentar 0 número de professores para atendimento e até um hotel local foi transformado em residência para médicos. A Prefeitura também enfrentava dificuldades na manutenção de transporte e alimentação para todo o pessoal médico, docentes e residentes. $E$ o mais importante, o hospital estava se tornando deficitário, atendendo exclusivamente pelo SUS." (Relatório da Fundação João Pinheiro, FJP, 1996: 71).

Além da incapacidade de o hospital atender a população regional, as Prefeituras também não tinham capacidade de assumirem todos os custos de 
serviços de saúde no município. Segundo depoimento dado pelo Prefeito de Perdões aos pesquisadores da Fundação João Pinheiro (FJP, 1996: 74):

"antes o pessoal não ia buscar ajuda na Secretaria de Saúde, eles se dirigiam ao prefeito que tinha de resolver todos os problemas, tais como, encaminhar e pagar médicos, exames, remédios, etc.".

Da mesma maneira que ocorreu na região do Alto São Francisco, Rafael Guerra visitou todos os municípios, cuja população procurava atendimento no Hospital, e organizou uma reunião geral com prefeitos, secretários municipais de saúde e vereadores, apresentando o problema e trazendo uma solução cooperação intermunicipal na área da saúde (dando o exemplo de Moema).

Ao longo do processo de conversas e convencimentos, Guerra foi superando a resistência encontrada, até que em junho de 1993, os prefeitos assinarem o termo de intenções para a criação do CISMARG.

A criação tanto do CISMARG quanto do CISASF foi fruto de uma proposta de integração do então diretor da Faculdade de Ciências Médicas com as Prefeituras Municipais, tendo em vista o funcionamento dos hospitais universitários localizados em Moema (CISASF) e Santo Antônio do Amparo (CISMARG). Além do investimento nos hospitais universitários, os Consórcios viabilizaram a implantação de atenção clínica especializada em oftalmologia, psiquiatria, gastroenterologia, otorrinolaringologia e fonoaudiologia no Alto Rio Grande; e em psiquiatria, neurologia e um programa de atenção integral à saúde da mulher, no Alto São Francisco. Nesta Microrregião, integrou-se ao Consórcio o Centro de Oftalmologia de Iguatama.

\section{Os Consórcios Intermunicipais de Saúde (CIS) como Política Pública Estadual}

Em 1994, Rafael Guerra foi convidado por Eduardo Azeredo (então candidato a governador de Minas Gerais pelo PSDB) a participar da elaboração de 
seu programa de governo. Eleito, Azeredo convidou Guerra para assumir a Secretaria de Saúde.

Entre as três prioridades definidas pelo Programa de Governo de Azeredo e estabelecidas pelo novo secretário de Saúde, estava a criação dos Consórcios Intermunicipais de Saúde em todo o Estado de Minas Gerais ${ }^{69}$, por meio de apoio aos municípios. As ações realizadas pela Secretaria Estadual de Saúde para auxiliar na implementação dos Consórcios eram as seguintes:

- Organização de reuniões com os prefeitos;

- Orientação sobre a elaboração de lei e aprovação pelas câmaras municipais da participação dos municípios e da sugestão de repasse entre $1 \%$ e $3 \%$ do FPM para manutenção dos CIS;

- Orientação à elaboração e aprovação pelos prefeitos do estatuto dos CIS;

- Orientação à eleição da cidade-sede e do presidente, vice-presidente e secretário geral do Consórcio;

- Orientação para criação do Colegiado de Deliberação e Controle, do Conselho Diretor (constituído pelos prefeitos), do Conselho Técnicoexecutivo (constituído pelos secretários de saúde) e do Conselho Curador e Fiscal (constituído por um representante de cada Conselho Municipal de Saúde) (ROCHA e FARIA, 2004. P. 28 e 29)

Este trabalho resultou na criação de 66 Consórcios Intermunicipais de Saúde, envolvendo 698 municípios (ver tabela 7), ao longo do período que se estende de 1995 a 1998, ou seja, ao longo da gestão do Governador Eduardo Azeredo,. Em 1997, foi constituído o Colegiado dos Secretários Executivos dos Consórcios de Saúde de Minas Gerais - COSECS, como instância capaz de articular os Consórcios Intermunicipais de Saúde de Minas Gerais e auxiliar na Coordenação da Política Estadual de Saúde.

\footnotetext{
${ }^{69}$ As outras duas prioridades do Secretário de Saúde Rafael Guerra eram: Programa Saúde da Família e descentralização e organização das urgências e emergências.
} 


\section{Tabela 3}

Número de Consórcios Intermunicipais de Saúde, segundo ano de implantação Estado de Minas Gerais 2000

\begin{tabular}{|c|c|c|}
\hline Ano de implantação & $\mathbf{N}^{\circ}$ de consórcios & $\mathbf{N}^{\circ}$ de municípios \\
\hline 1993 & 2 & 48 \\
\hline 1994 & 1 & 11 \\
\hline 1995 & 28 & 368 \\
\hline 1996 & 16 & 160 \\
\hline 1997 & 18 & 144 \\
\hline 1998 & 4 & 26 \\
\hline 1999 & 1 & 19 \\
\hline Total & 70 & 776 \\
\hline
\end{tabular}

Fonte: Secretaria Estadual de Saúde de Minas Gerais - 2000

IBGE / Contagem Populacional - 1997. Elaboração: Lima e Pastrana, 2000. P. 9.

Guerra estabeleceu como critério da política que os investimentos (equipamentos) não seriam feitos utilizando por base o município, mas sim os Consórcios, pois isto garantiria ganhos de escala em termos de atendimento.

Tendo em vista o longo processo de disseminação dos CIS pelo território de Minas Gerais, Guerra afirmou que o fundamental neste processo foi a "firmeza na decisão política" e cita um exemplo no qual um prefeito solicitou a ele um mamógrafo. O município deste prefeito tinha em torno de 8.000 habitantes, o que significava, pelas contas de Guerra, aproximadamente 4.000 mulheres, das quais aproximadamente 1.000 com idade superior a 40 anos. Assim, um mamógrafo seria usado em média por três mulheres por dia, ou seja, em torno de 15 minutos por dia.

Se não fosse a firmeza política da Secretaria de Estado em sugerir e estimular a formação de consórcios induzida, por exemplo, pela entrega de aparelhos e equipamentos, o mamógrafo teria sido entregue ao prefeito ainda que isto implicasse no baixo uso do equipamento. Em vez disso, Guerra sugeriu ao prefeito a formação de um Consórcio com municípios do entorno e garantiu a entrega do equipamento para a região. 
Embora a Secretaria Estadual de Saúde trabalhasse com 25 regiões administrativas, a localização dos CIS independia delas. A localização estava muito mais relacionada à facilidade de acesso, condições de atendimento regional, interesse em uma cidade sede e afinidades políticas.

Este argumento da firmeza política se comprova quando, na mudança de governo (1999), houve um refluxo do número de municípios envolvidos em CIS e mesmo do número de CIS existentes no Estado. Essa mudança de governo também ajudou a observar que, embora não houvesse mais estímulo do governo do Estado para a manutenção da prática de consorciamento, a lógica e o benefício da cooperação havia deitado raízes junto do setor saúde envolvido com as políticas públicas de saúde nos municípios.

\section{Conclusão}

As abordagens teóricas que sustentam este trabalho buscam verificar como surgem os Consórcios Intermunicipais e quais são os fatores que influenciam sua formação.

Dentre as hipóteses propostas, destacam-se três: a de que os Consórcios Intermunicipais são fruto da existência de capital social existente na região; a de que os Consórcios Intermunicipais são fruto da indução institucional de outros "níveis de governo" que não o nível municipal; e finalmente a de que os Consórcios Intermunicipais são resultado de uma complexa trama local desenrolada por um conjunto de atores dentre os quais se destaca um empreendedor político - que cumpre o papel de convencer os demais da existência de um problema e de uma alternativa para solucioná-lo.

O caso dos CIS de Minas Gerais é o que mais se pode usar a combinação das três hipóteses enumeradas acima. Para isso, antes de mais nada, é importante, separar os CIS de Minas Gerais em duas fases: a fase de implantação (primeiros CIS - anos de 1993 e 1994) e a fase de disseminação, quando Rafael Guerra, Diretor da Faculdade de Ciências Médicas, tornou-se Secretário de Estado. 
Na primeira fase, destaca-se uma seqüência de fatos que se sucedem ao longo do tempo e que intercalam problema - solução - problema - solução:

Um problema originário era a existência de um Hospital sem serventia, pois não tinha médico nem recursos para manutenção.

Esse problema originário foi solucionado por meio de uma parceria da Prefeitura com a Faculdade de Ciências Médicas, sendo que a Prefeitura autorizava o uso do Hospital, a Faculdade exercia suas atividades de Ensino graças à utilização do Hospital e, em troca, atendia os pacientes locais.

A solução para o problema originário, portanto, foi a parceria da Faculdade com a Prefeitura. O efeito adverso e inesperado da referida solução foi um novo problema (o aumento da demanda e o estrangulamento financeiro da parceria).

Então, há um novo problema: falta de recursos para manutenção dos serviços, em decorrência de uma combinação de benefício difuso pelo uso do hospital pela população regional e um custo (cada vez maior) para a manutenção do hospital concentrado sobre a Prefeitura de Moema.

A solução encontrada para esse novo problema foi a formação de um CIS por meio do qual parte do custo de manutenção seria rateado entre os municípios participantes.

O responsável pela origem da referida seqüência foi o Diretor da Faculdade, Rafael Guerra. Em seguida, quem o acompanhou e apoiou em todas as medidas foi o prefeito de Moema.

No caso da formação deste primeiro CIS em Minas Gerais, merece destaque o papel exercido pelas Câmaras Municipais, como atores políticos capazes de pressionar os prefeitos a participarem do CIS.

Na segunda fase de formação dos CIS em Minas Gerais, destaca-se a mudança de papel exercido por Rafael Guerra, que passa de Diretor da Faculdade para Secretário Estadual de Saúde. 
A partir dessa mudança, considerada a Janela de Oportunidade para colocar efetivamente o tema dos Consórcios na Agenda dos Governos Locais, há uma intensa disseminação dos CIS em Minas Gerais.

Neste caso, deve-se ressaltar que o Secretário Estadual de Saúde foi o principal responsável pela introdução do CIS nas agendas locais porque por um lado saiu "pregando" por todo o Estado sobre a importância dos CIS. Paralelamente a isso, atrelava a transferência de equipamentos para a área de saúde à existência de CIS, como forma de reduzir gastos com investimentos e aumentar o ganho de escala dos equipamentos transferidos para as diversas localidades.

Finalmente, merece destaque $\mathrm{o}$ fato de que ao longo do tempo as experiências de CIS foram favorecendo a criação de relações entre secretários de saúde para a troca de experiências e para a manutenção dos CIS independentemente de quem fosse o Secretário Estadual de Saúde ou mesmo o Prefeito de cada município que fizesse parte de algum CIS. 


\section{Conclusão: Análise Comparada dos Casos}

Neste capítulo conclusivo, antes de analisar os casos, o desafio inicial será resgatar as principais idéias expostas, analisadas e discutidas ao longo do capítulo que procurou apresentar o arcabouço teórico que se prestou a duas funções: auxiliar na concepção do roteiro de questões que orientaram as entrevistas de campo; e orientar a análise do material coletado ao longo da pesquisa de campo.

Além deste desafio inicial exposto acima, neste capítulo buscar-se-á analisar o sentido e o significado do longo percurso percorrido pelos diversos atores políticos e sociais ao longo de mais de duas décadas para, a partir da prática e de uma espécie de experimentalismo difuso, colocar a idéia dos Consórcios Intermunicipais na agenda do governo nacional.

Finalmente, neste capítulo conclusivo, buscar-se-á realizar uma análise comparada dos três casos estudados empiricamente ao longo desta pesquisa. A análise comparada será realizada a partir das principais categorias analíticas resgatadas do arcabouço teórico estudado previamente.

\section{As categorias Analíticas}

O arcabouço teórico que estruturou a análise dos estudos de caso, como já fora explicado anteriormente, são os seguintes: teoria da escolha racional; teoria do capital social; e teoria da formação de agendas de governo.

O arcabouço teórico da escolha racional confere aos estudos empíricos uma maior precisão nos resultados e a possibilidade de modelar os complexos jogos sociais a partir de poucas variáveis.

Esta análise valoriza os esquemas mais estruturados de incentivos e punições como mecanismos de induzir o comportamento dos atores sociais.

O problema nesse tipo de abordagem é que, na maior parte das vezes é preciso reduzir a complexa realidade social a uma estrutura na qual há poucos atores que atuam em um conjunto limitado de arenas. Além disso, essa 
abordagem da escolha racional, muitas vezes, desconsidera a construção histórica específica de cada uma das realidades sociais a que se propõe analisar.

Os estudos empíricos sobre a formação de Consórcios Intermunicipais que utilizaram a teoria do capital social privilegiaram variáveis relacionadas à cultura, à tradição e aos símbolos locais como referências importantes para moldar o comportamento dos atores políticos e sociais.

Esta perspectiva analítica reconhece o fator cultural como fator capaz de determinar certas características do funcionamento das organizações.

Um problema potencial deste tipo de abordagem é o risco em se desconsiderar certas variáveis do jogo político que acabam por moldar o comportamento dos atores no curto prazo.

Além dessas duas abordagens, ao longo deste trabalho, procurou-se enfatizar os aspectos analíticos desenvolvidos pelos neo-institucionalistas.

Finalmente, procurou-se, com maior ênfase inclusive, analisar o surgimento dos Consórcios Intermunicipais por meio do que se convencionou chamar de processo de formação de agendas governamentais.

Evidentemente que casos complexos como os da formação de consórcios não são facilmente enquadrados em uma ou várias teorias. As teorias serviram para orientar o olhar, para auxiliar na percepção de como o jogo da política influencia na constituição de uma política pública; e como a constituição de uma política pública não segue um curso retilíneo, mas tortuoso e complexo.

Construído o arcabouço teórico, procurou-se apresentar a questão dos Consórcios Intermunicipais ao longo dos anos 80 e dos anos 90. Esse enquadramento temático permitiu-nos perceber que ao longo dos anos 80, a introdução dos Consórcios nas agendas dos governos locais é explicada em grande medida por uma série de estímulos institucionais exógenos ao território em que o Consórcio Intermunicipal será implantado. No caso do Estado de São Paulo, por exemplo, o estímulo era gerado pelo governo do Estado por meio de sua Secretaria do Interior. 


\section{O que aprendemos com o recorte temático?}

A análise do capítulo que tratou de apresentar os Consórcios Intermunicipais como um tema a ser analisado no âmbito da Ciência Política nos sugere algumas conclusões: a primeira diz respeito aos mecanismos explicativos para a implantação dos Consórcios Intermunicipais em São Paulo (1983-1986); em seguida nos sugere que a trajetória dos Consórcios Intermunicipais como instrumento de política pública não segue uma trajetória linear ao longo do tempo, mas tortuosa e complexa; e finalmente nos permite identificar os atores e as arenas envolvidos ao longo do processo que se inicia em meados dos anos $80 \mathrm{e}$, para os propósitos deste trabalho, termina em 2005, com a aprovação e publicação de Lei específica que trata dos Consórcios Intermunicipais (Consórcios Públicos, nos termos da Lei).

Os mecanismos utilizados para a implantação dos Consórcios Intermunicipais neste período entre 1983-1986 combinavam argumentos e ações. Os argumentos diziam respeito aos ganhos de escala gerados pelas ações realizadas em conjunto com os municípios vizinhos para a resolução de problemas reconhecidamente comuns. As ações se diversificavam desde o deslocamento de equipes de técnicos para seminários e atividades regionais, até a formatação de termos de cooperação técnica ou convênios entre municípios e Estado para a disponibilidade de equipamentos dentre outros.

Este estímulo está muito mais relacionado com o que os neoinstitucionalistas sociológicos chamam de comportamento estratégico prático que com os esquemas mais estruturados propostos pelos neo-institucionalistas da escolha racional.

Essa forma de institucionalidade, por um lado induz a formação dos Consórcios Intermunicipais como organizações regionais, e por outro molda novos comportamentos mais cooperativos entre atores políticos municipais de uma mesma região. 
Além dos estímulos gerados exogenamente aos territórios nos quais seriam implantados os Consórcios Intermunicipais, a experiência de São Paulo (19831986) permite-nos observar outro fator explicativo para a implantação dos referidos Consórcios: a presença do empreendedor político. Um empreendedor político no âmbito estadual que era o governador e que estava preocupado com a criação de novos arranjos institucionais capazes de proporcionar uma gestão mais descentralizada e ao mesmo tempo mais articulada no território. Este empreendedor lança a idéia da descentralização coordenada ainda no período de campanha (torna o tema da descentralização um problema de política pública); procura encontrar soluções para o problema, dentre os quais os Escritórios Regionais de Governo e o estímulo aos Consórcios; e aproveita o clima de redemocratização do país e a existência de uma correlação retórica entre descentralização e democratização para fortalecer o discurso em prol das ações descentralizadas.

Este caso nos suscita a seguinte questão: será que um empreendedor político no âmbito do Estado é suficiente para induzir o comportamento dos atores políticos no âmbito local?

A impressão que se tem é que não. A necessidade de empreendedores políticos locais que auxiliem no processo de convencimento dos atores políticos locais (prefeitos, presidentes de Câmaras Municipais, vereadores, e líderes partidários). Kingdon (2003) ao tratar do tema provavelmente não discutiu a questão dos empreendedores articulados nos vários níveis da federação porque seu objeto analítico era a política do governo americano no âmbito federal.

Findo o Governo Montoro, o tema dos Consórcios Intermunicipais dá uma arrefecida no Estado de São Paulo, muito embora as experiências implementadas perdurem no tempo e tenham servido de modelo para as experiências posteriores em outros lugares (tanto Rafael Guerra - MG - quanto Léo Costa - MA - citam o caso do Consórcio Intermunicipal de Saúde de Penápolis - SP como experiência referência). 
O tema dos Consórcios voltam a ganhar força poucos anos depois (1989 em diante) na Região do $A B C$ paulista sob a liderança de Celso Daniel, prefeito de Santo André (PT-SP), que além de ser o empreendedor político do Consórcio Intermunicipal do $\mathrm{ABC}$, como vimos no capítulo 4 , também foi agente fundamental para a implementação do Fórum da Cidadania do $A B C$, da Câmara Regional e da Agência de Desenvolvimento do Grande ABC.

Nos anos 90, o tema dos Consórcios ganha destaque em outras regiões do país, como em Minas Gerais e no Paraná em torno do tema da Saúde; no Maranhão em torno do tema Produção e Abastecimento; em Santa Catarina (Quiriri) e no Rio Grande do Sul (Três Rios) em torno do tema ambiental.

Ao longo de todo este período o tema se espraia como mostram as bases de dados quantitativas e qualitativas e ainda assim entram de forma muito tímida na agenda do Governo Nacional.

Finalmente, o sobrevôo temático permite-nos perseguir o caminho feito pela idéia dos Consórcios Intermunicipais ao longo do tempo.

Neste aspecto, observa-se que atores selecionados ao longo da pesquisa como Celso Daniel e Rafael Guerra ocupam papéis diferentes ao longo de suas trajetórias políticas, mas em todos eles carrega consigo a idéia dos Consórcios Intermunicipais para as diversas arenas das quais participam.

\section{Análise Comparada: São Luís, Santo André e Minas Gerais}

Finalmente, neste capítulo conclusivo, buscar-se-á realizar uma análise comparada dos três casos estudados empiricamente ao longo desta pesquisa. Se os três capítulos pautados na pesquisa empírica seguiram uma espécie de linha cronológica apresentando os elementos analíticos e explicativos ao longo do tempo sem a devida preocupação em destacar cada um dos referidos elementos; a análise comparada proposta nesta seção será realizada a partir das principais categorias analíticas resgatadas do arcabouço teórico estudado previamente e dos já apresentados isoladamente nos já referidos capítulos empíricos. 
No caso dos Consórcios há sempre um duplo problema verificado: um problema setorial, que varia de região para região (em Minas Gerais foi o problema da saúde, no $\mathrm{ABC}$ foi a questão ambiental urbana e mais profundamente a questão do desenvolvimento econômico, em São Luís, foi a produção e o abastecimento das cidades com produtos de origem agrícola); e um problema relativo ao isolamento municipal na prática mais corriqueira de executar as políticas públicas visto que muitas vezes os prefeitos interpretam a autonomia municipal como sinônimo de autosuficiência e acabam não reconhecendo a interdependência de sua circunscrição com os municípios vizinhos, com o Estado e com a União.

Portanto, tratar da formação de agenda a partir de um objeto empírico como os Consórcios implica em reconhecer a sobreposição de dois problemas: um problema setorial e um problema de articulação territorial.

Assim, a formação dos Consórcios exige que os municípios vizinhos reconheçam um mesmo problema setorial em comum.

Dito isso, essa seção será organizada em cinco subitens: Instituições, Organizações, Arenas e Atores; A estrutura de Incentivos; O processo de Convencimento; A formulação do problema e a geração de alternativas; e A circulação das idéias e das pessoas.

\section{i. Instituições e Organizações}

Esta seção busca mapear e analisar quais são e que papéis desempenham as instituições, as organizações e os atores sociais e políticos, bem como identificar e analisar as arenas nas quais se deram os processos de convencimento dos atores envolvidos na formação dos Consórcios Intermunicipais analisados ao longo deste trabalho.

As principais instituições diretamente relacionadas com a formação dos Consórcios Intermunicipais são as instituições nacionais que definem as regras do jogo para todos os entes da Federação, dentre as quais: a forma federativa de 
organização do Estado brasileiro, segundo a qual os municípios são autônomos; a separação dos Poderes, segundo a qual cabe às Câmaras Municipais legislarem, autorizarem gastos do Poder Executivo, bem como fiscalizá-lo; o Poder Executivo Municipal, a quem cabe, em última instância, definir autonomamente as políticas públicas locais, muitas das quais sob as diretrizes de sistemas nacionais de políticas públicas como é o caso da Saúde e da Assistência Social.

No caso específico dos Consórcios Intermunicipais ora analisados, as políticas públicas com eles relacionadas são a política de Saúde para o caso de Minas Gerais; a política de meio ambiente e desenvolvimento regional para o caso de Santo André (SP); e a política de Abastecimento e Produção para o caso de São Luís (MA).

Assim, apreende-se que as instituições mais gerais incidem sobre todos os entes da Federação; que cada um dos casos reage de uma forma diferente diante das mesmas instituições nacionais existentes; que para o caso específico de São Luís, a política pública em torno da qual se articulou o Consórcio Intermunicipal não é propriamente uma política de atribuição municipal, segundo consta na Constituição Federal do Brasil (1988).

Estas instituições mais gerais acima enumeradas conformam as regras sobre as quais os atores agirão para formatar os respectivos Consórcios Intermunicipais.

Destaca-se que no caso dos dois primeiros Consórcios Intermunicipais de Minas Gerais, as Câmaras Municipais (na condição de instituições) exerceram papel fundamental no sentido de convencer os prefeitos da importância da formação dos consórcios como condição para a manutenção dos serviços de saúde prestados na região. Outra instituição importante para o caso desses primeiros Consórcios mineiros foi o envolvimento dos profissionais da saúde pública relacionados com o Sistema Único de Saúde (SUS) bem como a lógica e a sistemática de implantação e manutenção dos serviços de saúde por meio do SUS, na região. 
No caso do $A B C$ uma instituição importante por meio da qual se teceu a teia de sustentação da organização regional foi o Partido dos Trabalhadores (PT).

No caso do CINPRA, assim como no caso do ABC paulista, o processo de formação do Consórcio ficou, em termos institucionais, focado no Poder Executivo. Porém, diferentemente do caso paulista, não havia uma articulação partidária prévia e concentrada em torno de um município pólo que facilitava o diálogo entre os dirigentes dos Executivos Municipais.

As Câmaras Municipais cumpriram papel secundário ao longo do processo de criação do CINPRA. O único embate entre o Executivo e o Legislativo ocorreu em São Luís, quando um vereador do PSDB propôs que o Consórcio tivesse maior abrangência temática. No mais, não teve embate com a Câmara Municipal, nem em São Luís nem nos demais municípios. Este fato, corrobora a idéia do "super-poder" do Prefeito, frente ao Poder Legislativo ${ }^{70}$.

As organizações envolvidas com a formação de cada Consórcio, por sua vez, estavam muito diretamente relacionadas com o setor em torno do qual cada Consórcio se articulou. Assim, no caso do Consórcio de Saúde de Minas Gerais, as principais organizações envolvidas foram Faculdade de Ciências Médicas de Minas Gerais. Além dessa organização, no caso da formação do primeiro Consórcio analisado - Consórcio Intermunicipal de Saúde do Alto São Francisco houve apoio das Secretarias Municipais de Saúde. No caso do segundo Consórcio implantado - Consórcio Intermunicipal dos Municípios da Microrregião do Alto Rio Grande - além do apoio organizacional das Secretarias Municipais de Saúde, houve um apoio fundamental da Associação Microrregional de Município do Alto Rio Grande, inclusive do ponto de vista do empréstimo de espaço físico para a realização de reuniões do Consórcio.

\footnotetext{
${ }^{70}$ Abrucio e Couto (1996) e Abrucio (1998). Segundo Abrucio, há uma hipertrofia do Poder Executivo frente ao Poder Legislativo. Isso ocorre tanto na Esfera Federal, quanto Estaduais, quanto Municipal. É bem verdade que o debate em torno da esfera Federal indica também importante papel do Legislativo, como por exemplo Limongi (2006). No entanto, no âmbito municipal, há poucos trabalhos acadêmicos que discutem os papéis do Executivo e do Legislativo e suas relações, e o pouco que existe, indica força dos executivos municipais (Faria, 2002).
} 
No caso do $A B C$, as organizações envolvidas na formação do Consórcio foram fundamentalmente as Prefeituras Municipais, com destaque para as prefeituras dirigidas pelo Partido dos Trabalhadores (PT) que se empenharam mais intensamente. Destas prefeituras dirigidas pelo PT destaca-se a prefeitura de Santo André, seguida pela prefeitura de São Bernardo do Campo.

No período subseqüente (1993-1996), a formação do Fórum da Cidadania (1995) contou com a participação das mais diversas organizações da sociedade civil, desde Sindicatos de trabalhadores, representantes de Partidos Políticos, Igrejas, Universidades e entidades patronais. Ao todo, participaram da formação do Fórum mais de 100 organizações da sociedade civil.

A Câmara Regional, criada em 1997, contou com a participação dos governos locais, do governo estadual e da sociedade civil, todos representados num amplo conselho composto por 43 membros.

Finalmente, ainda tratando da presença das organizações na formação dos Consórcios Intermunicipais, deve-se destacar que no caso do CINPRA, houve o envolvimento de inúmeras organizações externas ao território (principalmente dos escritórios regionais da EMBRAPA) que conferiram ao Consórcio certa legitimidade e cumpriram certo papel de disseminar a referida iniciativa.

O processo de constituição do CINPRA mostrou a importância do envolvimento de organizações estruturadas como a EMBRAPA e os parceiros externos ao território. Mostrou também que, ao longo do processo, ocorre a mobilização de diferentes atores. Em princípio foram mobilizados técnicos na área rural e secretários de agricultura; em seguida os prefeitos; mais tarde os parceiros externos ao território. Não só a mobilização, mas também a estruturação de determinados atores se mostraram relevantes. A organização das secretarias municipais de agricultura e a contratação de três técnicos pelo CINPRA ajudam a constituir um "corpo" burocrático, com interesses próprios que vão se constituindo como uma importante força de apoio ao projeto. É fundamental, neste aspecto, considerar a conjuntura de desmonte da EMATER e da rede de apoio ao produtor rural por parte do Estado. 
Finalmente, qual foi o papel desempenhado pela sociedade civil na formação dos Consórcios nos territórios estudados?

A maior pluralidade de participação da sociedade civil foi observada na formação do "complexo institucional do Grande ABC". Nos CIS mineiros a participação da sociedade civil foi reduzida às organizações em torno do setor saúde.

No caso do CINPRA, apenas em torno de um Programa específico (Programa de Capacitação Ambiental), articulado em torno do Consórcio houve um envolvimento da sociedade civil. Nesta ocasião, houve a agregação de mais de cem entidades e organizações sociais que, entretanto, não tinham função deliberativa e sequer participaram da concepção do programa.

Enfim, a participação da sociedade civil nos projetos e atividades desenvolvidas na formação dos Consórcios, de modo geral, é baixa.

Finalmente no que diz respeito às arenas, observa-se que são múltiplas. Geralmente, os principais agentes políticos circulam, ao longo do tempo, por várias destas arenas.

\section{ii. A estrutura de Incentivos Institucionais}

Nenhum caso analisado recebeu um estímulo ou um conjunto de estímulos institucionais estruturados na acepção da Escolha Racional. Mesmo os Consórcios que usufruíram de algum tipo de estímulo institucional como foi o caso dos Consórcios de Saúde de Minas Gerais, este veio acoplado a uma ação política de um empreendedor de políticas públicas. Então não se pode dizer, neste caso especificamente, que o incentivo institucional foi suficiente para moldar o comportamento dos atores locais no sentido de formarem Consórcios Intermunicipais.

No caso mineiro, deve-se considerar que a implantação de Consórcios Intermunicipais de Saúde (CIS) torna-se uma política de Governo quando Eduardo Azeredo se elege governador. Neste momento, o apoio do governo do Estado por 
meio da garantia da implantação de equipamentos nas regiões que se organizassem em CIS pode ser considerado um estímulo institucional com forte influência sobre o comportamento dos atores locais. Isso pode ser observado pelo alto índice de formação de CIS no período em que Rafael Guerra foi Secretário Estadual de Saúde.

Nos casos do Grande $A B C$ e de São Luís não se pode falar em incentivos institucionais exógenos ao território.

\section{iii. O processo de Convencimento}

O processo de convencimento é diferente para cada uma das localidades. No caso de Minas Gerais, nos primeiros Consórcios Intermunicipais, Rafael Guerra propõe-se a conversar com os prefeitos e com os vereadores, tanto individualmente como em grandes reuniões. Guerra estava convicto de seus argumentos até porque atuava na condição de Diretor do Hospital Universitário Local e havia pensado no Consórcio Intermunicipal como resposta à crise de financiamento dos serviços por ele prestado, dado o efeito carona de municípios vizinhos.

Então, Rafael Guerra enumerou as vantagens que cada município tinha em manter os serviços no local, bem como as vantagens que ele próprio e população local também haveriam de ter.

O processo de convencimento ocorreu junto aos tomadores de decisão política (prefeitos e vereadores) e junto das equipes de médicos e profissionais da saúde que atuavam nos municípios circunscritos pelo Consórcio.

No caso de Santo André, o processo de convencimento foi feito por Celso Daniel inicialmente nas hostes do PT, depois junto dos demais prefeitos. A lógica da "racionalidade prática" também imperou no processo de convencimento. Celso Daniel as oportunidades de financiamento de grandes obras de infra-estrutura seriam geradas por meio de uma ação coletiva regional. 
Em momentos posteriores o processo de convencimento ocorre em arenas da sociedade civil (para o caso da formação do Fórum da Cidadania) e na arena do governo do Estado (para o caso da Câmara do Grande $A B C$ ).

Finalmente, no caso do CINPRA, Léo Costa mostra por meio de entrevista que o processo de convencimento é lento e permanente e ocorre tanto junto aos tomadores de decisão política quanto junto aos técnicos agrícolas locais.

Léo Costa gasta tempo em ampliar a rede para fora do Estado, por meio da formação de parcerias com órgãos técnicos diversos. Esse tipo de ação legitimava o Consórcio junto dos prefeitos e dos técnicos locais.

Para Léo Costa o processo de convencimento era uma combinação de discurso permanente e ações práticas.

\section{iv. A formulação do problema e a geração de alternativas}

No caso dos Consórcios Intermunicipais de Saúde de Minas Gerais, foi Rafael Guerra, quem formulou o problema nas diversas fases de implantação dos Consórcios Intermunicipais no Estado mineiro. Inicialmente, na condição de Diretor da Faculdade de Ciências Médicas, Rafael Guerra estava preocupado em resolver um problema criado no âmbito do Curso de Medicina de sua instituição. Ele havia criado um programa de Residência Médica por meio do qual os alunos precisariam fazer estágios e a própria residência em diversas clínicas médicas sempre em regiões de alta vulnerabilidade social como forma dos alunos conhecerem mais adequadamente a realidade social do Estado de Minas Gerais.

No caso de Santo André, Celso Daniel quem formula o problema por meio de diversos Seminários e Encontros e regionais.

No caso do CINPRA, foi Léo Costa, Secretário da Agricultura de São Luís, quem formulou o problema. Gerou um "dado" a partir de visitas ao CEASA Local de que $80 \%$ do abastecimento da cidade vinha de outros Estados, ou seja, o Maranhão era um "importador líquido" de produtos hortifrutigranjeiro. Esse dado em si desvela uma situação histórica que se torna problema na medida que o 
poder pública encara a referida situação como questão de governo. Junto ao problema formulado, Léo começa a elaborar as alternativas. A alternativa para equalização do problema identificado era a produção de alimento. No entanto, como produzir alimentos só em São Luís? Então a solução demandava uma ação coletiva pelo menos dos municípios vizinhos. Pensou-se então na alternativa da formação de um Cinturão Verde que esbarrava na autonomia dos municípios e na falta de prática da ação coletiva de municípios vizinhos. Paralelamente à idéia da ação conjunta para superar o problema formulado, o governo de São Luís, por meio de outra secretaria, pensava especificamente na ação conjunta dos 04 municípios da llha. A proposta, entretanto, encontrava resistência decorrente das diferenças partidárias. O entrave foi, para Léo Costa, uma oportunidade de aprendizado. Léo percebeu que a mobilização dos atores seria mais fácil se ocorresse em torno de apenas um tema, um setor, um problema comum; percebeu também que a mobilização deveria ser de Prefeito para Prefeito, de Secretário para Secretário, de Técnico para Técnico. Portanto, a equipe proponente deveria estar, em seu conjunto, apta para convencer seus pares.

Assim, em São Luís, a alternativa aos problemas formulados foi buscar a melhoria, a diversidade e a ampliação da produção rural por meio da ação "consorciada" dos municípios.

Havia, portanto, problema, alternativa e ambiente propícios para a implementação da alternativa proposta. O ambiente era a eleição de Jackson Lago. Assim, o Consórcio entrou na Agenda de Governo de Governo.

O que se percebeu ao longo do trabalho é que essas condições são relevantes para entrar nas agendas, mas galgar pontos e tornar-se cada vez mais prioridade do governo é uma questão que demanda mais tempo.

No caso do CINPRA, uma vez na agenda de Governo, o Consórcio desenvolveu-se. Foi gerando ações, chamadas pelos dirigentes do CINPRA de "vitrines tecnológicas", que eram, na verdade, desenvolvimento de projetos com a função de demonstrar a possibilidade real de disseminação da idéia (assim foi feito com diversos projetos). Paralelamente a essas ações, foi feito um intenso 
trabalho de convencimento por meio da mobilização da imprensa, da realização de encontros regionais, de encontros de prefeitos, de encontros de secretários, e da realização de cursos, palestras e seminários.

O processo de convencimento é diferente para cada uma das localidades. No caso de Minas Gerais, nos primeiros Consórcios Intermunicipais, Rafael Guerra propõe-se a conversar com os prefeitos e com os vereadores, tanto individualmente como em grandes reuniões. Guerra estava convicto de seus argumentos até porque atuava na condição de Diretor do Hospital Universitário Local e havia pensado no Consórcio Intermunicipal como resposta à crise de financiamento dos serviços por ele prestado, dado o efeito carona de municípios vizinhos.

Então, Rafael Guerra enumerou as vantagens que cada município tinha em manter os serviços no local, bem como as vantagens que ele próprio e população local também haveriam de ter.

O processo de convencimento ocorreu junto aos tomadores de decisão política (prefeitos e vereadores) e junto das equipes de médicos e profissionais da saúde que atuavam nos municípios circunscritos pelo Consórcio.

No caso de Santo André, o processo de convencimento foi feito por Celso Daniel inicialmente nas hostes do PT, depois junto dos demais prefeitos. A lógica da "racionalidade prática" também imperou no processo de convencimento. Celso Daniel as oportunidades de financiamento de grandes obras de infra-estrutura seriam geradas por meio de uma ação coletiva regional.

Em momentos posteriores o processo de convencimento ocorre em arenas da sociedade civil (para o caso da formação do Fórum da Cidadania) e na arena do governo do Estado (para o caso da Câmara do Grande ABC).

Finalmente, no caso do CINPRA, Léo Costa mostra por meio de entrevista que o processo de convencimento é lento e permanente e ocorre tanto junto aos tomadores de decisão política quanto junto aos técnicos agrícolas locais. 
Léo Costa gasta tempo em ampliar a rede para fora do Estado, por meio da formação de parcerias com órgãos técnicos diversos. Esse tipo de ação legitimava o Consórcio junto dos prefeitos e dos técnicos locais.

Para Léo Costa o processo de convencimento era uma combinação de discurso permanente e ações práticas.

\section{v. A circulação das idéias e das pessoas}

Esta seção busca resgatar e ressaltar a trajetória da idéia do Consórcio Intermunicipal e das pessoas que "apadrinharam" esta idéia, até porque idéias não andam sozinhas. Alguém (um agente político), por meio de conversas, de leituras, de contatos, adota, adapta e recria idéia da cooperação intermunicipal na forma de Consórcio Intermunicipal. Deste modo, procura-se compreender os caminhos percorridos pelos empreendedores políticos para levar a idéia do Consórcio Intermunicipal para outras arenas do debate político.

Dentre as arenas destacam-se os gabinetes do Poder Executivo e Legislativo, ambos nos três níveis de poder. No caso da formação dos Consórcios Intermunicipais de Saúde, em Minas Gerais, observa-se que Rafael Guerra, ainda diretor da Faculdade de Ciências Médicas de Minas Gerais, circulou pelos gabinetes dos Prefeitos da região em que instalou os dois primeiros Consórcios Intermunicipais de Saúde mineiros, pelas Câmaras Municipais destes mesmos municípios (para conquistar o apoio dos Vereadores e por meio desta aliança convencer os prefeitos da região a favor dos CIS), pelo gabinete e pela Assessoria técnica da Secretaria Estadual de Saúde (para negociar convênios, por meio do SUS). Em segundo momento, já na condição de Secretário Estadual de Saúde, Rafael Guerra percorre os municípios buscando convencer os prefeitos a formar CIS em suas regiões. E finalmente, na condição de Deputado Estadual, percorre os gabinetes de outros deputados, o apoio de senadores e negocia com a Subchefia de Assuntos Federativos da casa Civil da Presidência da República os detalhes de um Projeto de Lei que pretende regulamentar a formação de Consórcios Intermunicipais (consórcios públicos no termo da Lei). 
No caso de Santo André, o então Prefeito Celso Daniel procura, inicialmente, o apoio dos prefeitos eleitos pelo PT. Em seguida, procura o apoio dos demais prefeitos e busca, ao longo deste processo, a imprensa e os formadores de opinião pública, a favor da formação de um Consórcio Intermunicipal do Grande ABC. Em um segundo momento (1993-1996), período em que ainda não havia a reeleição, os prefeitos mais sensíveis à articulação regional não elegem os seus sucessores. Celso Daniel, então, junta-se a outras forças políticas regionais para fortalecer o Fórum da Cidadania do Grande ABC (este Fórum reúne mais de 100 associações da sociedade civil).

Em 1995, na condição de deputado federal, Celso Daniel participa dos debates em torno da emenda constitucional número 19, cujo conteúdo prevê a formação de consórcios públicos. Em 1997, quando retorna à Prefeitura de Santo André, retoma as articulações em torno do Consórcio Intermunicipal do Grande ABC. Em 1999, busca apoio do Governador do Estado para formar a Câmara Regional do Grande $A B C$, que reúne atores do governo estadual, dos governos locais e da sociedade civil.

Finalmente, no caso do CINPRA, a idéia de "cooperação" entre municípios ganha força e é debatida na Assembléia Legislativa do Estado do Maranhão. $\mathrm{Na}$ Assembléia havia duas idéias: uma de formar a Região Metropolitana da "Grande São Luís", e outra de estruturar a região por meio de Consórcio.

Naquela ocasião, formalmente, vence a proposta do Governo Estadual de criar a Região Metropolitana; na prática, prosperou o Consórcio Intermunicipal.

No caso do CINPRA, a idéia do Consórcio como alternativa ao problema da falta de abastecimento e baixa produção rural é fruto de um trabalho de pesquisa realizado pelo então Secretário de Agricultura de São Luís, Léo Costa, que inicialmente procura informações junto ao IBAM. Nesta ocasião os técnicos do IBAM indicam a Léo Costa uma experiência do Estado de São Paulo (a experiência do Consórcio de Saúde de Penápolis) e a experiência dos Consórcios Intermunicipais de Saúde de Minas Gerais ${ }^{71}$. Em posse do material do IBAM, a

${ }^{71}$ Aliás, o precursor dos Consórcios Intermunicipais de Saúde (CIS) de Minas Gerais confirma as conversas que teve com a equipe da Secretaria de Agricultura de São Luís, que viria formar o 
equipe maranhense visita a Secretaria Estadual de Saúde de Minas Gerais em busca de informações. Dessa viagem que tiram o modelo "formal" de constituição do CINPRA.

Uma vez constituído, o CINPRA dissemina a idéia de Consórcio, em sua vertente "produção e abastecimento" por todo o Maranhão e pelos estados vizinhos como o Piauí e Tocantins.

A idéia é mais intensamente disseminada pelo Estado depois que a experiência é premiada pelo PGPC e é finalmente apropriada pelo então prefeito de São Luís, Jackson Lago.

Nesta ocasião, Jackson Lago vê na experiência uma possibilidade de expandir seus horizontes eleitorais, ou seja, de se fazer conhecido para além do "Estreito do Mosquito"72, uma vez que pretendia disputar as eleições para o governo do Estado.

Especificamente, com relação ao CINPRA, deve-se destacar que foi possível observar, ao longo da pesquisa, alguns agentes políticos que levaram a idéia da cooperação intermunicipal e dos consórcios para outros postos decisórios. Neste aspecto, destacam-se:

- Chico Leitoa, ex-prefeito de Timon (1997-2000) e atual Diretor Estadual do Departamento de Estradas Rodagens, que agora está criando, no Estado, Consórcios Intermunicipais Rodoviários, para recuperação de Estradas. Chico Leitoa, quando prefeito de Timon (2001-2004), estimulado por Jackson Lago ${ }^{73}$, formou o CINPRA-COCAIS, constituído por 06 municípios

CINPRA, no sentido de municiá-los de informações e apresentar-lhes os modelos de documentos necessários (projetos de lei a serem apresentados às Câmaras Municipais solicitando autorização dos Legislativos Municipais, e Estatuto do Consórcio, dentre outros).

${ }^{72}$ Nas entrevistas e nas matérias de jornal, em diversos momentos, os depoentes e os articuladas, tratam do aumento de influência de Jackson Lago para além do Estreito do Mosquito, estreito que separa a llha de São Luís do continente. A referência, portanto, é alusiva à interiorização de uma eventual campanha eleitoral do então prefeito de São Luís, Jackson Lago.

${ }^{73}$ Segundo entrevista com Chico Leitoa, ele, como ex-prefeito, acompanhou a formação do CINPRA (1997). Depois, na condição de prefeito (2001-2004), criou, com apoio de Jackson Lago e Léo Costa, o CINPRA-COCAIS. Segundo entrevista com Domingos, ex-secretário de Agricultura de Timon (2001-2004), no período em que Chico Leitoa foi prefeito do município, reafirmou, em entrevista, que Chico Leitoa foi convidado a formar um CINPRA na região de Timon pelo próprio Jackson Lago (ambos são do PDT). Chico Leitoa convidou Domingos para tornar-se Secretário 
(atualmente são 10 municípios);

- José Mário, ex-secretário de agricultura de Vitória do Mearim (1997-2000) e prefeito de Vitória do Mearim (2005-2008), que inicialmente, na condição de Secretário Municipal, participou do CINPRA e agora (2005-2008) criou um Consórcio e uma Agência de Desenvolvimento com os municípios de sua região;

- Marco Aurélio, engenheiro agrônomo, ex-assessor do CINPRA, atualmente Superintendente da Agência Estadual de Pesquisa Agropecuária, Extensão Rural e Assistência Técnica do Maranhão. Segundo Marco Aurélio, a disseminação dos Consórcios será estratégica para realização dos trabalhos da Agência.

Assim, fica evidente que em cada caso estudado, houve o esforço do empreendedor político em identificar os interesses dos diferentes atores e convencê-los da importância de suas idéias. Observa-se também a multiplicação dos adeptos da idéia que a adotam e a levam para outras arenas e para outras instâncias.

\section{Conclusão}

Retomo à questão inicial: Como surgem os Consórcios Intermunicipais no Brasil, ao longo dos anos 90? Em outras palavras: como a despeito do tema ter se tornado de grande relevância para a agenda do governo nacional, em determinados territórios, tornou-se relevante? Esta foi a indagação original que orientou o desenvolvimento deste trabalho.

Para responder esta questão, partiu-se do pressuposto de que a institucionalização dos consórcios na forma da lei no âmbito federal não é necessária para que os Consórcios Intermunicipais surjam nas mais variadas localidades do país.

Municipal de Agricultura e a formar o CINPRA-COCAIS. Segundo o próprio Domingos, o percurso realizado para a formação do Consórcio foi participar do Encontro de Cidades, depois do Encontro de Prefeitos, sempre acompanhado pelo Léo Costa, reconhecido pelo Domingos como o mentor intelectual do CINPRA. 
Por meio do trabalho empírico, verificou-se, aliás, que a difusão experimental dos Consórcios Intermunicipais e o deslocamento de determinados empreendedores políticos que atuavam no âmbito local para o âmbito estadual (como é o caso de Rafael Guerra em Minas Gerais, que se torna Secretário de Estado) e Federal (como são os casos de Celso Daniel em São Paulo e de Rafael Guerra em Minas Gerais que se tornam Deputados Federais) ampliaram a pressão no sentido de sensibilizar mais intensamente o Governo Federal (Presidência da República e Congresso Nacional) para que este apreciasse Projeto de Lei que tratava da regulamentação dos Consórcios Intermunicipais.

Dado o pressuposto acima discutido, utilizei um arcabouço teórico composto por várias vertentes de pensamento, para buscar respostas à indagação original.

O referido arcabouço teórico procurou juntar elementos pertinentes à teoria da ação racional, teoria do capital social, e teoria da formação de agendas governamentais. Deve-se relembrar que, no momento em que iniciei os trabalhos já existiam estudos que utilizavam tanto a teoria da ação racional quanto a teoria do capital social para explicar o surgimento e o funcionamento de Consórcios Intermunicipais.

Não havia, entretanto, um estudo que buscasse encontrar elementos das duas teorias (ação racional e capital social) e agregasse a eles outros elementos recolhidos do corpo teórico sobre formação de agendas de governo.

Para os adeptos da teoria da escolha racional, os consórcios intermunicipais resultariam de uma série de estímulos exógenos ao território no qual está sendo criado. O incentivo seria vertical, uma vez que advém tanto da União quanto do Estado. O mecanismo explicativo para os adeptos da teoria da escolha racional é a ação estratégica do ator racional, que busca otimizar seus ganhos, dado um conjunto de possibilidades.

Os consórcios, compreendidos neste trabalho como organizações cooperativas de entes da mesma instância de governo, possibilitam a articulação de políticas públicas de "setores" de política pública como saúde, infra-estrutura, meio ambiente, desenvolvimento regional, produção rural e abastecimento 
alimentício, por exemplo, em determinado território, conferindo, teoricamente, maior racionalidade às políticas públicas em termos de menor fragmentação da ação e melhor utilização do recurso público.

Assim, produção de leis que, por exemplo, aumentem o volume de recursos per capita para municípios que participem de consórcios intermunicipais específicos em torno de determinado "setor" constituir-se-ia, na perspectiva dos estudiosos da ação racional em mecanismo institucional que, ao induzir o comportamento cooperativo dos municípios, aumentaria a racionalidade da política setorial no território.

O que se verificou por meio da pesquisa de campo, entretanto, foi que essa perspectiva isolada é insuficiente para explicar o surgimento dos Consórcios Intermunicipais.

Embora verdadeira como demonstrado por Teixeira, Mac Dowell e Bugarin (2002a; 2002b), a teoria da escolha racional não se mostrou suficiente para explicar o fenômeno da formação dos Consórcios Intermunicipais.

Por um lado, embora a indução ocorra sobre todos os municípios, talvez não seja uma indução forte suficiente para atrair os municípios, uma vez que nem todos os municípios se deixaram seduzir pelo estímulo institucional.

Por outro lado, o estímulo institucional quando realizado não apenas pela força da Lei, mas também por meio do apoio político de um "empreendedor de políticas públicas" que assume posição de tomador de decisão no âmbito do Estado, como ocorreu com Rafael Guerra em Minas Gerais, há resultados positivos como a criação de 28 Consórcios Intermunicipais no Estado (agrupando 368 municípios), além de uma organização inter-consórcios.

Além disso, deve-se considerar a existência de Consórcios como o CINPRA, caso em que a articulação ocorre em torno de um tema de política pública que não é sequer atribuição específica do município.

Neste caso o que levaria um município com tantos problemas a convencer seus vizinhos em formar um Consórcio Intermunicipal em torno de um tema que sequer é atribuição dos governos locais? 
Ainda buscando explicações para o surgimento e funcionamento dos Consórcios Intermunicipais, analistas adeptos da teoria do capital social, por sua vez, lançaram mão da hipótese de que os consórcios intermunicipais resultariam das relações de confiança locais independentemente dos estímulos externos. Assim, a constituição dos consórcios intermunicipais estaria diretamente relacionada à capacidade prévia dos municípios, seus agentes políticos e os atores sociais com raízes na localidade, estabelecerem laços e relações de confiança (verticais e horizontais).

A referida hipótese é verdadeira e explica casos como a formação de Consórcios Intermunicipais como o da Bacia do Rio Negro (Consórcio do Quriri $\mathrm{SC}$ ), localizado em Estado com forte e longa tradição cooperativista, como salienta Jacobi (2006).

No entanto, novamente, como explicar casos como o CINPRA, que surgiu em um Estado sem tradição cooperativista?

Diante do exposto, para responder à questão inicial, além de considerar as perspectivas da escolha racional e do capital social, adotei como pano de fundo uma perspectiva neo-institucionalista histórica que, ao analisar o papel das instituições sobre a conformação das organizações e sobre o comportamento dos atores, considera o fato de que as forças sociais em disputa estão sob as contingências da ação política cotidiana (sem, entretanto, desconsiderar a racionalidade dos atores e agentes políticos sociais).

A adoção dessas abordagens além de orientar a análise feita ao longo deste trabalho também serviu para formatar o roteiro de visitas de campo e de entrevistas com atores selecionados (ver Anexos 2 e 3 ).

Além disso, notando a complexidade do tema, considerei que a análise tornar-se-ia mais substanciosa se fosse ancorada também e principalmente no que a ciência política tem denominado formação de agendas governamentais.

A partir de então lanço as seguintes hipóteses:

- os consórcios intermunicipais dependem de dinâmicas locais; 
- os Consórcios Intermunicipais são temas relevantes em seus respectivos locais apenas para a "comunidade política" e para determinados setores formadores da opinião pública, mas não atingem o grande público;

- os Consórcios Intermunicipal resultam do aumento de reconhecimento das ações embrionárias levadas a cabo por um pequeno grupo de "crentes", de técnicos e políticos que crêem no consórcio como organização capaz de, por um lado, fortalecer a região em que foi instituído.

Do exposto e analisado ao longo deste capítulo, depreende-se então que apesar de as regras do jogo serem as mesmas, as formas de articulação política dos atores e das organizações diferenciam-se de lugar para lugar. Os mecanismos causais que moldam o comportamento dos atores e dos agentes políticos em torno da formação de um Consórcio Intermunicipal são diversos. Um deles é o grau de confiança pré-existente entre os agentes políticos que se articulam em torno da formação do Consórcio Intermunicipal. Este mecanismo é perceptível, por exemplo, no caso do Grande $A B C$, onde, apesar da grande quantidade de atores e agentes políticos envolvidos, os principais deles eram os dirigentes dos Executivos municipais, filiados ao Partido dos Trabalhadores, então a relação de confiança entre eles advinha das relações partidárias.

Outro mecanismo causal observado é a forma como o empreendedor político propõe, discute e convence os mais diversos agentes sociais e polítcos nas diversas arenas.

As três hipóteses foram verificadas ao longo do trabalho de campo. Em cada um dos casos observou-se a construção de um problema: no caso de Minas Gerais o problema foi construído em torno da saúde; em Santo André em torno da questão ambiental, do desenvolvimento econômico, mas fundamentalmente em torno da necessidade de infra-estrutura urbana; em São Luís, em torno do abastecimento e da produção de alimentos. 
Em todos os casos, o Consórcio é a solução para a resolução do problema. Em cada caso, há gênese tanto da construção do problema quanto de sua resolução por meio de uma ação coletiva e cooperada entre entes federativos autônomos têm peculiaridades muito próprias. Não é possível dizer que haja um padrão. É possível dizer, entretanto, que mais importante que esquemas de benefícios e punições é a força do argumento. Em todos os casos, foi possível verificar, nos moldes do neo-institucionalismo sociológico, uma certa racionalidade prática não induzida pelos referidos esquemas de indução; mas conformada por argumentos por meio do qual os atores eram capazes de perceber as vantagens em participar de um arranjo cooperativo para superar o problema comum.

Nos casos de Minas Gerais e São Luís, os empreendedores políticos, responsáveis pela formulação do problema e da procura de solução tinham experiência prévia nos setores com os quais o problema estava relacionado: Rafael Guerra é médico e atua na área da saúde; Léo Costa atuou na Secretaria Estadual da Agricultura (ainda na época de Epitácio Cafeteira) e desenvolveu vários programas agrícolas quando fora Prefeito Municipal (Barreirinhas, 19891992). Diferentemente dos dois, a trajetória de Celso Daniel era eminentemente do campo da política não propriamente como gestor, como técnico, mas como tomador de decisão (Prefeito Municipal).

Com exceção da experiência de Santo André na qual houve a participação da sociedade civil, nos outros casos a sociedade civil praticamente não atua. Além disso, o tema do Consórcio, em nenhum dos casos, foi tema de campanha. É verdade que em São Luís, a experiência do Consórcio colaborou muito para aumentar os horizontes da candidatura a governador do então prefeito de São Luís. Apesar disso, em nenhum caso, o Consórcio foi mote de campanha, o que indica que não é um tema que sensibiliza a opinião pública como mecanismo de resolução de problema.

Ainda assim, deve-se considerar que nos três casos o Consórcio ganha força na medida em que suas ações passam a gerar resultado. A força advém da conquista de novos atores políticos (prefeitos e vereadores) e técnicos e 
burocratas que vêem, na perspectiva da "racionalidade prática" vantagens em aderir ao projeto.

Finalmente, em todos os casos é possível perceber a abertura de uma janela de oportunidades; e também verdade que nem em todos os casos é possível perceber que a oportunidade gerada pela abertura da janela impulsiona o Consórcio da agenda de governo para a agenda de decisões.

No caso de Minas Gerais, a janela de oportunidade é a eleição de Eduardo Azeredo para governador do Estado que leva junto a ele Rafael Guerra para a pasta da saúde. Nota-se aumento substancial do número de consórcios no Estado.

No caso do $A B C$, o quadro de mudança política facilitou a implantação da agenda regional e da ação coletiva, porque diferentemente de São Luís, havia, no $A B C, 03$ dos quatro prefeitos da Região, pertencentes ao mesmo partido político (Partido dos Trabalhadores).

As janelas de oportunidades no caso do Grande $A B C$ são abertas e fechadas sucessivamente a cada eleição. Neste caso, como o "empreendedor de políticas públicas" é o tomador de decisão (diferentemente do enunciado por Kingdon (2003), segundo o qual o empreendedor de políticas públicas geralmente atua em algum posto do governo, da burocracia, da academia, de consultorias, mas não é o tomador de decisão) não dá pra dizer que ele não aproveita a oportunidade. Celso Daniel, ao cumprir os dois papéis (tomador de decisão e empreendedor de políticas públicas) constrói as oportunidades e usufrui delas.

Janela de Oportunidade especial no caso do Grande $A B C$ foi a que propiciou a criação da Câmara do Grande ABC. Neste caso, o empreendedor de políticas públicas e, ao mesmo tempo, tomador de decisão, Celso Daniel, vislumbrou na eleição do governador do Estado, interessado em aturar na área de infra-estrutura, uma janela de oportunidade.

A abertura e fechamento sucessivos das janelas de oportunidade em Santo André indicam que o processo de formação e fortalecimento dos instrumentos de ação regional podem ocorrer de forma paulatina. Num primeiro momento, constrói- 
se o consórcio; depois o Fórum e mais tarde a Câmara. Essa sucessão indica também que mesmo enfraquecido, em alguns momentos, a burocracia interna formada e o histórico de serviços e ações gerados fazem com que a organização sobreviva ainda que por inércia. Isso também ocorre no caso do CINPRA que mantém o apoio formal do atual prefeito de São Luís, mas o perdeu na prática. Assim a força do CINPRA advém atualmente do Governo do Estado e do histórico e ampliação da rede de relações técnicas e políticas construídas ao longo do tempo.

No caso do CINPRA, a janela de oportunidade foi a premiação da experiência pelo Programa Gestão Pública e Cidadania. A partir deste momento, o Consórcio como idéia recebe atenção do então prefeito que aproveita a oportunidade para disseminá-la no Estado, no entanto, o problema que deu origem ao problema não foi devidamente tratado.

Finalmente, quero chamar atenção para o fato de que ao longo do trabalho os Consórcios foram vistos como solução para problemas diferentes e a preocupação foi em observar como esta solução entrou na agenda de decisões governamentais para resolver problemas diferentes. 


\section{Bibliografia}

ABRAMOVAY, Ricardo. O capital social dos territórios: repensando o desenvolvimento rural. Economia Aplicada, v.4, $n^{\circ} 2$, páginas 379-397, abril-junho, 2000.

ABRUCIO, Fernando (1988). "O ultrapressidencialismo estadual". In: ANDRADE, Regis de Castro (org.). Processo de Governo no Município e no Estado: uma análise a partir de São Paulo. Edusp/Fapesp. São Paulo.

ABRUCIO, Fernando (1994). "Os Barões da Federação". Lua Nova, n³3. São Paulo.

ABRUCIO, Fernando and Márcia Miranda Soares. Redes federativas no Brasil. Cooperação intermunicipal no Grande $A B C$. Fundação Konrad Adenauer, São Paulo, 2001.

ABRUCIO, Fernando e COSTA, Valeriano Mendes Ferreira (1999). Reforma do Estado e o Contexto Federativo Brasileiro. Konrad Adenauer (Série Pesquisas n¹2), São Paulo.

ABRUCIO, Fernando e COUTO, Cláudio (1996). "A redefinição do papel do Estado no âmbito local". São Paulo em Perspectiva, 10 (3). São Paulo.

ABRUCIO, Fernando e SAMUELS, David (1997). "A Nova Política dos Governadores". Lua Nova, n40/41. São Paulo.

ABRUCIO, Fernando Luiz e SOARES, Márcia Miranda. Redes federativas no Brasil: cooperação intermunicipal no grande ABC. São Paulo: Fundação Konrad Adenauer, Série Pesquisas n²4, 2001.

ABU-EL-HAL, Jawdat. O debate em torno do capital social: uma revisão crítica. Revista Brasileira de Informações Bibliográficas em Ciências Sociais (BIB), n47, páginas 65-79, 1999.

ALMEIDA, M. Hermínia Tavares de. Federalismo, Democracia e Governo no Brasil: Idéias, Hipóteses e Evidências, BIB - Revista Brasileira de Informação Bibliográfica em Ciências Sociais 51, 2001. 
ALMEIDA, Maria Hermínia Tavares (1995). Federalismo e Políticas Sociais. Revista Brasileira de Ciências Sociais, São Paulo, volume 10, n²8, pp.88-108.

ALVES, Márcio Moreira (1980). A força do povo: democracia participativa em Lages. São Paulo: Editora Brasiliense.

ANDERSON, J. (1984). Public Policy-Making. Nova lorque, Holt, Rinehart and Winston.

ARRETCHE, Marta (1996). Mitos da Descentralização: mais democracia e eficiência nas políticas públicas. Revista Brasileira de Ciências Sociais, São Paulo, volume 11, n³1, pp.44-66.

ARRETCHE, Marta (2002). Federalismo e relações intergovernamentais no Brasil: a reforma de programas sociais. Revista Dados, volume $45, n^{\circ} 3$, Rio de Janeiro.

ARRETCHE, Marta (2003). Financiamento Federal e Gestão Local de Políticas Sociais: o difícil equilíbrio entre regulação, responsabilidade e autonomia. Ciência \& Saúde Coletiva, volume $8, n^{\circ} 2$, Rio de Janeiro.

ARRETCHE, Marta e MARQUES, Eduardo (2002). Municipalização da Saúde no Brasil: diferenças regionais, poder do voto e estratégias de governo. Ciência \& Saúde Coletiva, volume $7, n^{\circ} 3$, Rio de Janeiro.

AZEVEDO, Sergio de e GUIA, Virgínia R. dos Mares. Reforma do Estado e Federalismo: os desafios da governança metropolitana. In: Ribeiro, Luiz Cezar de Queiroz (Org.). O futuro das metrópoles: desigualdades e governabilidade. Rio de Janeiro, FASE, 2000 pp. 525-549.

AZEVEDO, Sergio de e GUIA, Virgínia Rennó dos Mares. Trajetória e Dilemas da Gestão Metropolitana no Brasil. In: Rio Urbana, Fundação CIDE, Rio de Janeiro, Março 2002.

BARBOZA, Hélio Batista e AROUCA, Francine Lemos. CINPRA - Consórcio Intermunicipal de Produção e Abastecimento. In: BARBOZA, Hélio Batista e SPINK, Peter (orgs.). 20 Experiências de Gestão Pública e Cidadania. São Paulo: Programa Gestão Pública e Cidadania, 2002.

BASTOS, Tavares (1937). A Província. Editora Companhia Nacional. São Paulo. 
BAUMGARTNER, Frank R.; JONES, Bryan D. Attention, boundary effects, and largescale policy change in air transportation policy. In: ROCHEFORD, D. A.; COBB, Roger W. (org.). The politics of problem definition. Shaping the policy agenda. Lawrence: University of Kansas Press, 1994.

BAUMGARTNER, Frank R.; JONES, Bryan D. Attention, boundary effects, and largescale policy change in air transportation policy. In: ROCHEFORD, D. A.; COBB, Roger W. (org.). The politics of problem definition. Shaping the policy agenda. Lawrence: University of Kansas Press, 1994.

BERGOC, Gilson Jacob. Associações de Municípios do Estado do Paraná: cooperação e planejamento para o desenvolvimento regional. São Paulo. Faculdade de Arquitetura e Urbanismo / Universidade de São Paulo (FAU-USP), 2001.

BORJA, Jordi e CASTELLS, Manuel, Local y Global, La gestión de lãs ciudades em la era de la información, United Nations for Human Settlements, Madrid, Santillana de Ediciones, S.A., 1997.

BOSSO, Christopher J. The contextual bases of problem definition. In: ROCHEFORD, D. A.; COBB, Roger W. (org.). The politics of problem definition. Shaping the policy agenda. Lawrence: University of Kansas Press, 1994.

BOURDIEU, Pierre. Le Capital Social. Notes Provisairies. Actes de la Recherche en Sciences Sociales, v.3, n²-3, 1980.

BRASIL. Constituição da República Federativa do Brasil. 1967.

BRASIL. Constituição da República Federativa do Brasil. 1988.

BURGESS, Michael. Federalism as Political Ideology: Interests, Benefits and Beneficiaries in Federalism and Federation. In: Burgess M. e Gagnon, A.-G. (eds.) Comparative Federalism and Federation: Competing Traditions and Future Developments, pp. 69-93. New York: Harvester Wheatsheaf, 1993.

CALDAS, Eduardo de Lima. CITRESU - Consórcio Intermunicipal de Tratamento e Resíduos Sólidos Urbanos. In: LOTTA, Gabriela Spanghero, BARBOZA, Hélio Batista, TEIXEIRA, Marco Antonio Carvalho e PINTO, Verena. 20 Experiências de 
Gestão Pública e Cidadania. São Paulo: Programa Gestão Pública e Cidadania, 2003.

CAPELLA, Ana C. N. O Papel das Idéias na Formulação de Políticas Públicas. In: Encontro Nacional de Administração Pública e Governo. São Paulo. 22 a 24 de novembro de 2006.

CAPELLA, Ana. C. N. O Processo de Agenda-Setting na Reforma da Administração Pública (1995-2002). Tese de Doutorado apresentada ao Programa de PósGraduação em Ciências Sociais (PPGCSo) da Universidade Federal de São Carlos. São Carlos, UFSCar, 2004.

CARNEIRO, José Mário Brasiliense. Consórcios, krese e relações intergovernamentais. In: Informativo Cepam. Consórcio: uma forma de cooperação intermunicipal. São Paulo: Fundação Prefeito Faria Lima - Cepam. Unidade de Políticas Públicas, volume 1, número 2, 2001.

CARNEIRO, José Mário Brasiliense. O município e as relações intergovernamentais no cotidiano da base federativa. Cadernos Adenauer, São Paulo: Fundação Konrad Adenauer, Ano 1, nº 2000.

CARVALHO, Vanderlei Souza. Consórcio Intermunicipal de Recuperação da Bacia Hidrográfica do Ribeirão Lajeado. In: FUJIWARA, Luis Mario, ALESSIO, Nelson Luiz Nouvel e FARAH, Marta Ferreira Santos (orgs.). 20 Experiências de Gestão Pública e Cidadania. São Paulo: Programa Gestão Pública e Cidadania, 1998.

CLEMENTE, Roberta. Câmara do Grande ABC - Pacto de Governança para uma Gestão Regional Pública, Democrática, Compartilhada, Efetiva e Responsável. In: FUJIWARA, Luis Mario, ALESSIO, Nelson Luiz Nouvel e FARAH, Marta Ferreira Santos (orgs.). 20 Experiências de Gestão Pública e Cidadania. São Paulo: Programa Gestão Pública e Cidadania, 1999.

COBB, Roger W.; ELDER, Charles D. Issues and agendas. In: THEODOULOU, Stella and CAHN, Matthew A. Public plicy: the essential readings. Upper Saddle River. NJ, Prentice Hall, 1995. 
COBB, Roger; ROSS, Jennie-Keith; ROSS, Marc Howard. Agenda Building as a Comparative Political Process. The American Political Science Review, v.70, páginas 126-138, 1976.

Cocco, Giuseppe; Silva, Gerardo and Sperotto. A Agência de Desenvolvimento do Grande $A B C$ paulista entre a Agenda Regional e a Ação Territorial. Consultancy report written for the Regional Development Agency and UNCHS, July 2001

COHEN, M., MARCH, J., OLSEN, J. (1972). "A garbage can model of organizational choice". In: administrative science quarterly, ${ }^{\circ} 17, \mathrm{pp}: 1-25$.

COLEMAN, James. Social Capital in the Creation of Human Capital. American Journal of Sociology, v.94, supplement, páginas 95-120, 1988.

CRUZ, Maria do Carmo Meirelles Toledo. Consórcios intermunicipais de saúde, educação e assistência social no Estado de São Paulo. In: Informativo Cepam. Consórcio: uma forma de cooperação intermunicipal. São Paulo: Fundação Prefeito Faria Lima - Cepam. Unidade de Políticas Públicas, v.1, n², 2001.

CRUZ, Maria do Carmo Meirelles Toledo. Consórcios intermunicipais: uma alternativa de integração regional ascendente. In: CACCIA-BAVA, Sílvio, PAULISC, Veronika e SPINK, Peter (organizadores). Novos contornos da gestão local: conceitos em construção. São Paulo: Instituto Pólis, Programa Gestão Pública e Cidadania/FGV-EAESP, 2002.

DANIEL, Celso (1988). Poder Local no Brasil Urbano. Espaço \& Debate, vol.8, n²4, pp.26-39.

DANIEL, Celso e SOMEKH, Nadia. Gestão compartilhada, limites e possibilidades: a experiência do grande $A B C$. In: Informativo Cepam. Consórcio: uma forma de coopera;áo intermunicipal. São Paulo: Fundação Prefeito Faria Lima - Cepam. Unidade de Políticas Públicas, volume 1, número 2, 2001.

DANIEL, Celso. Uma experiência de desenvolvimento econômico local: a Câmara Regional do Grande ABC. In: GUIMARÃES, Nadya A. e MARTIN, Scott (organizadores). Competitividade e desenvolvimento: atores e instituições locais. São Paulo: Editora Senac, 2001. 
DOWBOR, Ladislau (1996). "Governabilidade e Descentralização". São Paulo em Perspectiva, 10 (3). São Paulo.

DOWNS, Anthony. Up and down with ecology: the issue-attention cicle. The Public Interest, $n^{\circ} 28$, páginas 38-50, 1972.

ELDER, Charles D.; COBB, Roger W. Agenda-Building and the Politics of Aging. Policy Sciences Journal, v.13, n¹, 1984.

EMIRBAYER, M. (1997). "Manifesto for relational sociology". In: American Journal of Sociology. Vol. 103, n².

FALLETI, T. (2005). "A seqüencial theory of decentralization: Latin American cases in comparative perspective". American Political Science Review, volume 99, $\mathrm{n}^{\circ} 3$, august.

FARAH, Marta. Parcerias, novos arranjos institucionais e políticas públicas no nível local de governo. Revista de Administração Pública, 35, 1, 119-134, 2001.

FARAH, Marta e SPINK, Peter. The brazilian public management and citizenship program. In: VII CLAD, Lisboa, 8 a 11 de dezembro de 2002.

FERNANDES, Antonio S.A. O capital social e a análise institucional e de políticas públicas. Revista de Administração Pública (RAP), v.36, n³, páginas 375-398, 2002.

FRANÇA, Cássio. Formação de Agenda e Processo Decisório nos Governos FHC e Lula. Uma análise sobre as dinâmicas e as oportunidades de negociação no processo de tomada de decisão do setor elétrico. Tese de Doutorado apresentada ao Programa de Doutorado em Administração Pública e Governo da Escola de Administração de Empresas de São Paulo da Fundação Getúlio Vargas. São Paulo, 2007.

FUJIWARA, Luis e JÁBALI, Paulo. Programa de Proteção aos Mananciais. In: FARAH, Marta Ferreira Santos e BARBOZA, Hélio Batista (orgs.). 20 Experiências de Gestão Pública e Cidadania. São Paulo: Programa Gestão Pública e Cidadania, 2001. 
FUKS, Mario. Arenas de ação e debate públicos: conflitos ambientais e a emergência do meio ambiente enquanto problema social no Rio de Janeiro. Dados - Revista de Ciências Sociais, v.1, n41, páginas 87-113, 1998.

FUKS, Mario. Arenas de ação e debate públicos: conflitos ambientais e a emergência do meio ambiente enquanto problema social no Rio de Janeiro. Dados - Revista de Ciências Sociais, v.1, n41, páginas 87-113, 1998.

FUKS, Mario. Conflitos ambientais no Rio de Janeiro: ação e debate nas arenas públicas. Rio de Janeiro: Editora UFRJ, 2001.

FUKS, Mario. Conflitos ambientais no Rio de Janeiro: ação e debate nas arenas públicas. Rio de Janeiro: Editora UFRJ, 2001.

FUNDAÇÃO JOÃO PINHEIRO. Avaliação dos Consórcios Intermunicipais de Saúde dos Municípios das Microrregiões do Alto Rio Grande e do Alto São Francisco, Governo do Estado de Minas Gerais, Belo Horizonte, março de 1996.

GUIMARÃES, Luisa e GOMES, Maria Angélica. Contexto institucional e regulatório do desenvolvimento de quatro experiências de consórcios de saúde. In: Informativo Cepam. Consórcio: uma forma de coopera;áo intermunicipal. São Paulo: Fundação Prefeito Faria Lima - Cepam. Unidade de Políticas Públicas, volume 1, número 2, 2001.

HALL, Peter e TAYLOR, Rosemery C.R. As Três Versões do Neo-Institucionalismo. Lua Nova, n58, 2003, páginas 193-223.

HILGARTNER, Stephen; BOSK, Charles. The rise and fall of social problems: a public arenas model. American Journal of Sociology, v.94, n¹, páginas 53-78, 1988.

HIRSCHMAN, Albert. Getting ahead collectively: Grassroots Experiences in Latin Amercia. Elmsford, NY, Pergamon Press, 1984.

http://www.brasil.gov.br/emquestao. Entrevista cedida por Ermínia Maricato a "em questão", editado pela Secretaria de Comunicação de Governo e Gestão Estratégica da Presidência da República, n. 5, em 13 de agosto de 2004. 
JACOBI, Pedro e TEIXEIRA, Marco Antonio Carvalho. Consórcio Quiriri: programa Intermunicipal de Tratamento Participativo de Resíduos Sólidos da Região do Alto Rio Negro Catarinense. In: FARAH, Marta Ferreira Santos e BARBOZA, Hélio Batista (orgs.). Novas Experiências de Gestão Pública e Cidadania. Rio de Janeiro: Editora FGV, 2000.

JACOBI, Pedro. Consórcio Quiriri: Programa Intermunicipal de Tratamento Participativo de Resíduos Sólidos da Região do Alto Rio Negro Catarinense. In: JACOBI, Pedro e PINHO, José Antonio (org.). Inovação no campo da gestão pública local: novos desafios, novos patamares. Rio de Janeiro: Editora FGV, 2006.

KEINERT, Tania Margarete Mezzomo e ROSA, Tereza Etsuko da Costa. Descentralização e parceria estado-município: o consórcio como instrumento da política estadual da saúde. In: Informativo Cepam. Consórcio: uma forma de cooperação intermunicipal. São Paulo: Fundação Prefeito Faria Lima - Cepam. Unidade de Políticas Públicas, volume 1, número 2, 2001.

KINGDON, John W. Agendas, alternatives, and public policies. New York: HarperCollins, 2003 (especialmente capítulos 8 e 9).

KLIJN, E. (1998). "Redes de políticas públicas: una visión general". Texto obtido no sítio: http://revista-redes.rediris.es/webredes/textos/Complex.pdf

KLINK, Jeroen, Regionalismo e Reestruturação no Grande ABC Paulista - São Paulo: Uma Perspectiva Brasileira de Governança Mteropolitana. Artigo apresentado no Foro Internacional sobre Ciudad Región Bogotá-Cundinamarca, em Bogotá, Colômbia, de 28 a 29 de agosto de 2003.

KLINK, Jeroen. A Cidade-região. Regionalismo e reestruturação no Grande $A B C$ Paulista, DPA Editora, Rio de Janeiro, 2001.

KLINK, Jeroen. O Novo Regionalismo à maneira do $A B C$ : em busca de uma economia regional de aprendizagem. In: Rio Urbana, Fundação CIDE, Março 2002, pp. 8489

KNOKE, D. (2003). "The sociopolitical construction of national policy domains. Obtido no sítio: http://www.soc.umn.edu/ knoke/ 
KOSICKI, Gerald. Problems and opportunities in agenda-setting research. Journal of Communication, v.43, n², páginas 100-127, 1993.

KUGELMAS, Eduardo, SALLUM JR., Brasílio e GRAEFF, Eduardo (1989). "Conflito Federativo e Transição Política". São Paulo em Perspectiva, 3 (3), São Paulo.

LACZYNSKI, Patrícia (2003). FUNDEF: seus primeiros resultados no Estado de São Paulo. São Paulo, (Dissertação de Mestrado apresentada à Fundação Getulio Vargas / Escola de Administração de Empresas de São Paulo FGV-EAESP).

LAHÓZ, Francisco Carlos Castro e BROCHI, Dalto Favero. O consórcio intermunicipal das bacias dos rios Piracicaba e Capivari e a gestão compartilhada dos recursos hídricos. In: Informativo Cepam. Consórcio: uma forma de coopera;áo intermunicipal. São Paulo: Fundação Prefeito Faria Lima - Cepam. Unidade de Políticas Públicas, volume 1, número 2, 2001.

LIMA, Ana Paula e PASTRANA, Rosa. Perfil dos Consórcios Intermunicipais de saúde do Estado de Minas Gerais. Relatório de Pesquisa. Brasil. Ministério da Saúde. OPAS, 2000: http://www.opas.org.br/servico/Arquivos/Sala3840.pdf

LIMA, Ana Paula e PASTRANA, Rosa. Diagnóstico da Situação atual de Consórcios Intermunicipais de Saúde no Brasil. Relatório de Pesquisa. Brasil. Ministério da Saúde. OPAS, 2000. http://www.opas.org.br/servico/Arquivos/Sala3840.pdf

LEI 11.107, de 06 de abril de 2005. Dispõe sobre normas gerais de contratação de consórcios públicos e dá outras providências.

LEVY, Evelyn (1997). Democracia nas Cidades Globais: um estudo sobre Londres e São Paulo. Studio Nobel, São Paulo.

LEVY, Evelyn. Ganhar e ganhar: estratégias de negociação bem sucedidas entre os municípios, os estados e a união. In: CACCIA-BAVA, Sílvio, PAULISC, Veronika e SPINK, Peter (organizadores). Novos contornos da gestão local: conceitos em construção. São Paulo: Instituto Pólis, Programa Gestão Pública e Cidadania/FGV-EAESP, 2002. 
LONGO, Carlos Alberto (1982). Finanças Governamentais num Regime Federativo: um Estudo sobre a Distribuição de Receitas e Encargos entre Esferas de Governo no Brasil. FEA-USP. São Paulo.

LOCKE, Richard. Construindo Confiança. Econômica, volume 3, número 2. Dezembro de 2001. Páginas 253-281.

MANTOVANI, Mário César. Consórcio intermunicipal: instrumento de ação e desenvolvimento de políticas públicas e participação social em meio ambiente. In: Informativo Cepam. Consórcio: uma forma de cooperação intermunicipal. São Paulo: Fundação Prefeito Faria Lima - Cepam. Unidade de Políticas Públicas, volume 1, número 2, 2001.

MARQUES, Eduardo (1997). "Notas críticas a literatura sobre Estado, políticas estatais e atores políticos". In: Boletim de Informações Bibliográficas em Ciências Sociais, $n^{\circ} 43$.

MARQUES, Eduardo (2003). Redes sociais, instituições e atores políticos no governo da cidade de São Paulo. São Paulo: Editora Annablume, 2003.

MAY, J. e WILDAVSKY, A., editores. (1977). The policy cycle. Beverly Hills-London.

MAYER, Robert N. Gone yesterday, here today: consumer issues in the agenda-setting process. Journal of Social Issues, v.47, n¹, páginas 21-39, 1991.

MATTOS, Janaina. Programas de Disseminação de Experiências de Governos Locais no Brasil em Contexto de Redemocratização e de Descentralização. Dissertação de Mestrado apresentada ao Programa de Doutorado em Administração Pública e Governo da Escola de Administração de Empresas de São Paulo da Fundação Getúlio Vargas. São Paulo, 2004.

McCOMBS, Maxwell E.; SHAW, Donald L. The evolution of agenda-setting research: twenty-five years in the marketplace of ideas. Journal of Communication, v.43, $n^{\circ} 2$, página 58-67, 1993.

MELLO, Diogo Lordello de. Associativismo como instrumento de desenvolvimento dos governos locais: a experiência brasileira e de outros países. In: Revista de Administração Pública, 31(6): 55-66, novembro/dezembro, 1997. 
MELO, Marcus André (1996). "Crise Federativa, Guerra Fiscal e 'Hobbesianismo Municipal': efeitos perversos da descentralização?". São Paulo em Perspectiva, 10 (3). São Paulo.

MELO, Marcus André. Governance e reforma do Estado: o paradigma agente x principal. In: Revista do Serviço Público, ano 47, volume 120, número 1, janeiro-abril, 1996 (67-79).

MENICUCCI, Telma Maria Gonçalves (2005). A implantação da Reforma Sanitária: a formação de uma política. Fundação João Pinheiro, Belo Horizonte, 2005 (Texto para Discussão n¹9)

MENICUCCI, Telma Maria Gonçalves. Ruptura e Continuidade: a dinâmica entre processos decisórios, arranjos institucionais e contexto político - o caso da política de saúde. Fundação João Pinheiro, Belo Horizonte (Texto para Discussão n²1).

MOISÉS, Hélvio Nicolau. Cooperação intermunicipal para a gestão do lixo. In: Informativo Cepam. Consórcio: uma forma de coopera;áo intermunicipal. São Paulo: Fundação Prefeito Faria Lima - Cepam. Unidade de Políticas Públicas, volume 1, número 2, 2001.

MULLER, Pierre. Les Politiques Publiques. Paris: Presses Universitaires de France, 1990.

NORTH, Douglass. Institutions. Journal of economic perspectives. Volume 5, número 1. Winter, 1991 (97-112).

NORTH, Douglass. Instituciones, cambio institucional y esempeño econômico. México: Fondo de Cultura Econômica, 2001.

OSTROM, Elinor. Crossing the Great Divide: Coproduction, Synergy, and Development. World Development, v.24, nº, páginas 1073-1087, 1996.

OSTROM, Vincent, Charles Tiebout, and Robert Warren. The Organization of Government in Metropolitan Areas, American Political Science Review, 55, pp. 831-42, 1961. 
PINDYCK, Robert E RUBINFELD, Daniel. Microeconomia. São Paulo: Prentice Hall, 2002.

PREFEITURA DE SÃO BENTO DO SUL. Lei Orgânica do Município de São Bento do Sul, de 05 de abril de 1990. http://www.saobentodosul.sc.gov.br. Acesso em 20 de maio de 2006.

PUTNAM, Robert (1996). Comunidade e democracia - a experiência da Itália moderna. Rio de Janeiro: Editora FGV, 2000.

REZENDE, Fernando (1995). Revista de Economia Política. Volume 15, n³ (59).

RIBEIRO, José Mendes e COSTA, Nilson Rosário. Consórcios Municipais no SUS. Texto para Discussão 669. IPEA. Brasília, setembro de 1999.

ROCHA, Carlos Alberto Vasconcelos e FARIA, Carlos Aurélio Pimenta de. Cooperação Intermunicipal, Reterritorialização da Gestão Pública e Provisão de Bens e Serviços Sociais no Brasil Contemporâneo: a Experiência dos Consórcios de Saúde em Minas Gerais. In: IV Encontro Nacional da Associação Brasileira de Ciência Política. Rio de Janeiro: PUC, 21124 de julho de 2004.

ROCHEFORD, D. A.; COBB, Roger W. Problem definition: an emerging perspective. In: ROCHEFORD, D. A.; COBB, Roger W. (org.). The politics of problem definition. Shaping the policy agenda. Lawrence: University of Kansas Press, 1994.

ROGERS, Everett M.; DEARING, James W.; BREGMAN, Dorine. The anatomy of agenda-setting research. Journal of Communication, v.43, $\mathrm{n}^{\circ} 2$, página $68-84$, 1993.

SÃO PAULO, Governo do Estado (1987). A Batalha da Alimentação. Apresentação: MONTORO, André Franco e HOMEM DE MELO, Fernando. São Paulo.

SÃO PAULO, Governo do Estado (1987). A Batalha da Descentralização e Participação no Governo Montoro. Apresentações: MONTORO, André Franco e FIGUEIREDO, Carlos. São Paulo.

SCHNEIDER, Mark, SCHOLZ, John, LUBELL, Mark, MINDRUTA, Denisa e EDWARDSEN, Matthew. Building Consensual Institutions: networks and the 
national estuary program. In: American Journal of Political Science, v.47, $n^{\circ} 1$, janeiro, páginas 143-158, 2003.

SECRETARIA DE ESTADO DO PLANEJAMENTO E SECRETARIA DE ESTADO DA EDUCAÇÃO, CIÊNCIA E TECNOLOGIA. Governo do Estado de Santa Catarina: mais perto das regiões e dos municípios. Revista de Administração Municipal. Rio de Janeiro. IBAM. Maio/junho. 2005. Ano 50, n²53.

SOUZA, Celina. Regiões Metropolitanas: Condicionantes do Regime Político. In: Lua Nova $n^{\circ}$ 59, 2003.

SOUZA, Celina. Políticas Públicas: uma revisão da literatura. Sociologias (UFRGS). Porto Alegre, v.08, n¹6, páginas 20-45, 2006.

SOUZA, Herbert José de (1982). "Município de Boa Esperança: participação popular e poder local". In: MOISÉS, José Álvares et al. Alternativas populares de democracia: Brasil, anos 80. Rio de Janeiro: Editora Vozes.

SPINK, Peter. Parcerias e alianças com organizações não-estatais. In: CACCIA-BAVA, Sílvio, PAULICS, Veronika e SPINK, Peter (organizadores). Novos contornos da gestão local: conceitos em construção. São Paulo: Instituto Pólis, Programa Gestão Pública e Cidadania/FGV-EAESP, 2002.

STUART MILL, John. A lógica das ciências morais. São Paulo: Editora lluminuras, 1999.

TEIXEIRA, Luciana, MAC DOWELL, Maria Cristina e BUGARIN, Maurício. Incentivos em Consórcios Intermunicipais de Saúde: uma Abordagem da Teoria de Contratos. Texto para Discussão 894. IPEA. Brasília, julho de 2002.

TEIXEIRA, Luciana, MAC DOWELL, Maria Cristina e BUGARIN, Maurício. Incentivos em Consórcios Intermunicipais de Saúde: uma Análise à Luz da Teoria dos Jogos. Texto para Discussão 893. IPEA. Brasília, julho de 2002.

TILLY, Charles (1992). "Prisioners of the State". In: Historical sociology, n¹33.

TOCQUEVILLE, Alexis de. A Democraica na América. São Paulo. Martins Fontes, 1998.

TRINDADE, José Raimundo Barreto. CINPRA - Consórcio Intermunicipal de Produção e Abastecimento no Estado do Maranhão. In: FARAH, Marta Ferreira Santos e 
BARBOZA, Hélio Batista (orgs.). Novas Experiências de Gestão Pública e Cidadania. Rio de Janeiro: Editora FGV, 2000.

YIN, Robert. Estudo de Caso: planejamento e métodos. Porto Alegre: Bookman, 2005.

WHITEHEAD, Laurence (1999). "Jogando boliche no Bronx: os interstícios incivis entre a sociedade civil e a sociedade política". Revista Brasileira de Ciências Sociais, volume 14, n²41, 1999. 


\section{Anexo 01 \\ Nota Metodológica: a opção pela pesquisa qualitativa}

A distinção entre métodos de pesquisa de base qualitativa e quantitativa pressupõe a opção entre dois tipos de pesquisa. De um lado estão os modelos que são matematicamente rigorosos, dotados de grande potencial de explicação (não de generalização) de relações entre poucas variáveis de comportamento que pode ser isolado. De outro lado vêm aqueles modelos que são capazes de lidar com variados domínios e abranger um maior número de variáveis, ao preço de perderem o rigor matemático e terem suas conclusões mais discutíveis.

Três dimensões principais distinguem as pesquisas qualitativas das quantitativas: a natureza do envolvimento do pesquisador; a coleta de dados e o tipo de dado coletado e o método de estabelecimento de generalizações.

A natureza de envolvimento é vista como a chave com as quais lidam diferentes estilos de pesquisa (BRYMAN, 1989).

A relação entre o pesquisador com o objeto na pesquisa quantitativa costuma ser bem superficial e breve ou não ocorre. A pesquisa qualitativa, por sua vez, fundamenta-se em entrevistas e na possibilidade direta de observação e envolvimentos pessoais do pesquisador com o fenômeno pesquisado. A interação entre entrevistador e entrevistados, por exemplo, pode ser decisiva para a interpretação dos dados coletados.

As pesquisas quantitativas, por sua vez, partem da premissa de que devem permitir replicabilidade.

A pesquisa qualitativa faz uso de maior contato com o objeto da pesquisa para criar um quadro mais complexo das interrelações envolvidas e considera a possibilidade apenas de uma replicabilidade parcial dos resultados: devido à interação do observador com o objeto, não existem duas observações idênticas.

Com relação à coleta de dados e às características dos dados coletados, nota-se que tanto pesquisadores envolvidos em pesquisa qualitativa quanto aqueles envolvidos com pesquisas quantitativas iniciam a pesquisa depois de 
realizado um trabalho conceitual e teórico. Apesar disso, podem, ao longo da pesquisa, incorporar novos elementos à sua estratégia inicial de pesquisa e refinar a pesquisa teórica do trabalho. O pesquisador pode ainda começar o estudo sem ter identificado com precisão as variáveis a considerar.

Finalmente, com relação ao método de estabelecimento de generalizações, em uma pesquisa quantitativa hipóteses são formuladas a partir da teoria, uma vez que esta tem o papel fundamental de explicação sobre os fenômenos. Os resultados dos testes são indicativos da validade da teoria como suporte à sua confirmação. Têm valor em si como conhecimento do fenômeno estudado. Dados qualitativos somente são conhecimento quando inseridos no trabalho teórico.

O ponto de vista adotado nesta pesquisa assume que o conjunto de problemas em questão não pode ser tratado com a expectativa de respostas exatas e universais. Ao contrário, devido à sua condição de fenômenos sociais complexos, são, por natureza, dotados de ambigüidades, multidimensões e densas cadeias de causalidade e interrelacionamento.

Diante disso, foi adotado o método de estudo de caso. Segundo YIN (1989), um estudo de caso é um método de investigação baseado no questionamento empírico sobre um fenômeno contemporâneo. O estudo de caso concentra-se nas relações, principalmente de causalidade ou precedência entre contexto e fenômeno em situações em que os limites entre ambos não se dão como claramente delimitados.

Outra aplicabilidade dos estudos de caso, ainda de acordo com YIN (1989), encontra-se em situações segundo as quais o pesquisador não apresenta controle sobre o comportamento dos eventos e nas quais sua atuação como observador tem muito pouca influência sobre o fenômeno social observado.

Uma consideração central no desenho de uma pesquisa de estudo de caso é a seleção dos casos. O número de casos selecionados depende das particularidades da pesquisa. De acordo com YIN (1994), estudos de casos podem ser desenhados para envolver um único ou múltiplos casos. Múltiplos casos são mais úteis quando se busca comparações e um forte teste de um 
padrão de conhecimento semi-estruturado. Casos únicos são passíveis de ser utilizados em circunstâncias específicas: casos emblemáticos que partem de uma teoria consolidada; casos cujas particularidades fazem-nos únicos e casos que servem para ilustrar e revelar aspectos significativos de um conhecimento produzido (YIN, 1994).

No caso deste trabalho, será adotada a perspectiva dos casos múltiplos e analisados por meio do consagrado método de comparação desenvolvido por Stuart Mill (1999).

A demonstração na variação dos fatores explicativos (variáveis independentes) e explicados (variáveis dependentes) pode ser feita por meio da orientação lógica de pesquisa comparada, apresentada por Stuart Mill (1999: 7982), que inclui os métodos da semelhança e da diferença.

De acordo com o método da semelhança, se dois ou mais casos de um fenômeno sob investigação têm apenas uma de muitas possíveis circunstâncias causais em comum, então a circunstância no qual todos os casos concordam é a causa do fenômeno de interesse. O método da semelhança é uma busca por padrões de invariância, isto é, visa-se determinar que possível variável causal está constantemente cruzando todos os casos. No método da diferença, os fatores causais são similares e observam-se diferenças nos resultados políticos entre o caos, porém, um fator explicativo crucial, que é variado cruzando todos os casos, é relacionado como causa desse diferentes resultados.

Quando dois casos inseridos em contextos muito diferentes, apresentam resultados semelhantes, a meta da investigação é identificar a semelhança responsável por tais resultados. Ao invés de destacar as diferenças entre os objetos, o investigador estuda a semelhança casualmente crucial entre tais objetos.

A materialização da estratégia de pesquisa em procedimentos investigativos levou a uma pesquisa constituída de várias fases de coleta de dados articuladas ao trabalho teórico. 
Além da revisão da literatura sobre os vários temas e dimensões que compõem o problema e da observação inicial semi-estruturada dos consórcios, realizou-se uma pesquisa exploratória sobre os casos escolhidos.

Assim, para a realização da coleta, tratamento e análise de dados na pesquisa, foram utilizados três níveis sucessivos de aproximação:

- primeiro nível: observação preliminar semi-estruturada dos consórcios intermunicipais. Neste primeiro nível da pesquisa foram feitos levantamentos de informações no que considero as principais bases de dados disponíveis sobre experiências "inovadoras" de gestão pública municipal, quais sejam: Instituto Pólis, Programa Gestão Pública e Cidadania da Fundação Getúlio Vargas, ILDES-FES e Centro de Estudos e Pesquisas em Administração Municipal;

- segundo nível: pesquisa exploratória para elaboração de visão panorâmica das experiências; e

- terceiro nível: estudo dos casos por meio de entrevistas semiestruturadas realizadas junto a atores selecionados.

\section{A pesquisa de campo: São Luís (MA), o ABC paulista e o Caso Mineiro}

Esta seção tem dois objetivos: resgatar a história da pesquisa de campo em São Luís (MA); e apresentar os procedimentos adotados.

O resgate da história da pesquisa de campo está diretamente relacionado com a necessidade de apresentar o grau de envolvimento do pesquisador com o objeto empírico a ser analisado. Para a realização de uma pesquisa desta natureza há uma série de dificuldades a serem enfrentadas, dentre as quais: a aproximação dos atores; o estabelecimento de uma relação com o informante na qual o pesquisador "confia desconfiando", porque em última instância o informante está informando sobre a atividade profissional e política a que ele se dedicou nos últimos anos, portanto, está informando sobre algo em que seu envolvimento foi intenso, o que, muitas vezes, o impossibilita de ter um afastamento crítico. Assim, 
cabe ao pesquisador, por um lado a aproximação junto do informante; e por outro, o afastamento crítico. Evidentemente, os instrumentos de coleta de informação auxiliam na adoção dessa postura de "aproximação desconfiada".

Esta pesquisa de campo, então, tem sua história que começa em 2000 quando li um artigo $^{74}$ sobre o Consórcio Intermunicipal de Produção e Abastecimento (CINPRA) de São Luís. Tratava-se de um artigo que se preocupava em apresentar os diversos projetos desenvolvidos pelo CINPRA.

Em 2001, tive a oportunidade de conversar com o então Secretário Executivo do CINPRA, Léo Costa, quando veio a São Paulo participar de um debate sobre Consórcios no CEPAM.

Em 2002, fazendo parte do grupo de avaliadores do Programa Gestão Pública e Cidadania da Fundação Getúlio Vargas, vi as fichas do CINPRA submetendo-se novamente ao ciclo de premiação ${ }^{75}$.

Resolvi saber mais sobre essa experiência. Os Consórcios Intermunicipais chamavam-me atenção desde os anos 80 , quando o governo democrático de Franco Montoro no Estado de São Paulo passou a estimular a prática da ação conjunta entre municípios.

Em 2002, realizei a primeira entrevista com Léo Costa para discutir o CINPRA numa perspectiva que, naquela época, chamava de "Desenvolvimento Econômico Local".

Em 2005, quando fui a Humberto de Campos, pelo PGPC/FGV, para visitar uma experiência de política pública relacionada com Comunidades Pesqueiras, aproveitei minha estada no Maranhão para visitar a Sede do CINPRA, conhecer

74 TRINDADE, José Raimundo Barreto. CINPRA: Consórcio Intermunicipal e Produção e Abastecimento no Estado do Maranhão. In: FARAH, Marta Ferreira Santos e BARBOZA, Hélio Batista (organizadores). Novas Experiências de Gestão Pública e Cidadania. Rio de Janeiro: Editora FGV, 2000.

${ }^{75}$ O Programa Gestão Pública e Cidadania (PGPC) criou, em 1996, um Ciclo de Premiação para coletar, registrar, sistematizar e premiar práticas inovadoras em gestão pública nos âmbitos dos municípios, estados, e povos indígenas. Embora o PGPC ainda exista e permaneça realizando diversos estudos no âmbito subnacional, o Ciclo de Premiação foi encerrado em 2006 (foram realizados 10 Ciclos de Premiação). 
alguns dos projetos, e entrevistar o já ex-secretário executivo do CINPRA Léo Costa, e o então Secretário Executivo do CINPRA Júnior Lobo.

Nestas entrevistas, foi utilizado um roteiro aberto e a condução da entrevista foi orientada por questões que diziam respeito ao histórico do CINPRA.

Nesta ocasião eu já havia pesquisado sobre os Consórcios em geral: os antecedentes propostos pelo Governo Montoro, e já havia estabelecido que este trabalho abordaria a formação dos Consórcios Intermunicipais, numa perspectiva que estaria localizada na fronteira entre a política pública e a política propriamente dita.

Nesta ocasião, eu já tinha lido sobre vários consórcios instituídos no Brasil, bem como me preocupado com as possibilidades de abordagens teóricas que pudessem iluminar as possíveis respostas. O CINPRA, então, do meu ponto de vista, era uma experiência inovadora para o contexto em que estava inserida ${ }^{76}$.

Mas, ainda me intrigava saber:

- Como, do ponto de vista político, essa experiência foi implantada?

- Quais eram e como foi o processo de atração dos principais atores sociais e políticos para a constituição dessa ação cooperada entre municípios?

- Como surgiu e se disseminou a idéia do CINPRA no Estado do Maranhão?

Então, me organizei para realizar uma segunda série de entrevistas, desta vez, mais focadas, e com maior abrangência de atores.

Nesta segunda série de entrevistas, o roteiro da entrevista foi orientado pelos elementos presentes num arcabouço teórico composto por uma série de

\footnotetext{
${ }^{76} \mathrm{O}$ debate sobre inovação nos termos da gestão pública subnacional foi realizado por SACHS, Ignacy (1985); FARAH, Marta e SPINK, Peter (1999); PINHO (2004). O conceito de inovação, inspirado em Schumpeter, diz respeito à introdução de uma novidade (novas práticas) em contexto e momento específicos da localidade em que a novidade é introduzida, e resulta em mudanças com relação a políticas, ações ou comportamentos vigentes. Para Sachs (1985) há cinco esferas passíveis de inovação. Para Farah e Spink (1999), inovação diz respeito à introdução de mudança qualitativa ou quantitativa em relação a práticas anteriores; impacto na melhoria da qualidade de vida; à capacidade de transferência "tecnológica"; à ampliação ou consolidação do diálogo entre sociedade civil e agentes públicos; e finalmente, à utilização de recursos e oportunidades de forma responsável, na perspectiva do desenvolvimento auto-sustentável.
} 
conceitos presentes nas teorias da Escolha Racional, do Capital Social e da Formação de Agendas Governamentais, com ênfase nesta última.

Nesta rodada de entrevistas (2007), foram entrevistados novamente os dois Secretários executivos do CINPRA; o ex-prefeito de São Luís e atual governador, Jackson Lago; um ex-assessor técnico do CINPRA e atual superintendente da recém criada Agência Estadual de Pesquisa Agropecuária, Extensão Rural e Assistência Técnica; o ex-prefeito de Timon, que inicialmente participou do CINPRA e depois fundou o segundo Consórcio Intermunicipal de Produção e Abastecimento do Maranhão, na região de Timon; um ex-secretário de agricultura do Município de Vitória do Mearim (que depois de secretário, tornou-se prefeito); o ex-prefeito de Humberto de Campos; o ex e também atual Secretário de Agricultura de Timon (único a permanecer no cargo, apesar da alternância política que houve no município); o ex-secretário de agricultura de Chapadinha.

Destaca-se que os atores envolvidos com o CINPRA vão construindo um campo político tal, que os opositores ou desconhecem a prática e o modo de operação da articulação em torno do Consórcio ou, no máximo, afirmam que esta articulação está diretamente relacionada com o projeto de poder do então prefeito de São Luís, Jackson Lago ${ }^{77}$.

Assim, do ponto de vista metodológico, esta pesquisa assumiu entrevistar uma gama variada de atores, todos que ou desde o início ou ao longo do processo envolveram-se diretamente com a formação do CINPRA.

Além das duas séries de entrevistas, realizei uma série de leituras, dentre as quais, uma de artigos e filmes sobre o contexto político do Estado; outra de editoriais, artigos e reportagens que tratavam do CINPRA, editadas nos principais

77 Em 2002, o jornal O Estado do Maranhão (sem data) publica editorial indicando que a candidatura do prefeito de São Luís, Jackson Lago, ao governo do Estado do Maranhão estaria sendo preparada por meio de um documento intitulado "Projeto para 2002". Este documento teria a pretensão de reforçar a imagem do prefeito no interior com o intuito de derrubar os argumentos da oposição a Lago segundo os quais o cacife político do então prefeito não ultrapassaria o "Estreito dos Mosquitos". Ainda segundo o referido editorial, o documento "Projeto para 2002" definiu como fundamental para o projeto eleitoral a vinculação direta do então prefeito aos "consórcios de produção". Este tipo de editorial indica, para os propósitos deste trabalho, que o CINPRA alcançou resultados simbólicos suficientes para que os órgãos de imprensa reconheçam alguma força político-eleitoral nele. 
jornais de circulação no Estado do Maranhão - O Pequeno, O Imparcial e o Estado do Maranhão; e finalmente, uma terceira, com os artigos mais analíticos sobre a experiência em questão.

Do ponto de vista metodológico, para escrever o estudo de caso sobre o $A B C$ paulista, lancei mão, de uma vasta revisão bibliográfica sobre o Grande $A B C$ Paulista, uma vez que a região foi amplamente estudada (Maricato, 1977; Ianni, 1980; Abramo, 1986; Antunes, 1988; Sader, 1988; Rodrigues, 1990; Boito, 1991; Keck, 1991; Simões, 1992; Martins, 1994; Clemente, 1999; Klink, 2000; Abrucio e Soares, 2001; Daniel, 2001; Daniel e Somekh, 2001). Apesar da ampla quantidade de estudos, este trabalho baseia-se principalmente nas referências mais recentes, principalmente Clemente (1999), Klink (2000) e Abrucio e Soares (2001).

Além da referência bibliográfica, este capítulo, assim como os demais capítulos relativos ao trabalho empírico, baseia-se também em entrevistas realizadas com atores locais. No caso específico deste capítulo, foi realizada uma entrevista com Jeroen Klink, ex-secretário de Relações Internacionais e exsecretário de Desenvolvimento e Ação Regional da Prefeitura Municipal de Santo André, que participou ativamente da formação do complexo institucional que buscou a cooperação regional.

O estudo de caso dos Consórcios em Minas Gerais foi sustentado pela leitura e análise dos estudos de Lima e Pastrana (2000a), Lima e Pastrana (2000b) e Rocha e Faria (2004).

Além destes estudos acima citados, o estudo de caso sobre os Consórcios Intermunicipais de Saúde em Minas Gerais se respaldou também em entrevistas realizadas com o Doutor Rafael Guerra, ex-diretor da Faculdade de Ciências Médicas de Minas Gerais, um dos articuladores dos prineiros Consórcios Intermunicipais de Saúde (CIS) em Minas Gerais, ex-secretário estadual de Saúde de Minas Gerais, e atual Deputado Federal (PSDB-MG). 


\section{ANEXO 02 Instrumento de Coleta de Informações para a Pesquisa de Campo: Roteiro da Entrevista}

1 (T) - Nome do Entrevistado. Partido pelo qual foi eleito. Composição do partido.

2 (T) - Trajetória Política: Partidos Políticos nos quais foi Filiado, Candidaturas a Cargos Eletivos, Cargos Eletivos, Militância em Movimentos Sociais (relação prévia com algum grupo político do Maranhão?)

3 (CS) - Na sua cidade há algum tipo de organização social forte? Organização de trabalhadores rurais, de comerciantes, de professores, algum time de futebol, grupo ou clube esportivo?

4 (A) - Compromissos de Campanha (tem relação com o tema do consórcio? Quais?). Quais foram os compromissos de campanha? As prioridades temáticas e setoriais estabelecidas durante a campanha eleitoral?

5 (A) - Que tema foi introduzido primeiro no seu governo: produção e abastecimento ou consórcio? Como foi essa introdução?

6 (A) - Quem introduziu o tema da produção e do abastecimento no seu governo?

7 (A) - Por que a introdução do tema esteve relacionada com a organização do Consórcio? (por que o tema? Por que o consórcio?) 
8 (A) - A situação da agricultura e do abastecimento era relativamente a mesma até o momento da implantação do consórcio ou no período imediatamente anterior à referida implantação a situação do referido setor havia sido alterada?

9 (A) - Algum indicador apresentava alteração da situação da agricultura em seu município?

10 (A) - Algum indicador apresentava alteração da situação de algum setor ou tema em seu município? Por que, apesar da indicação da referida alteração, você resolveu entrar num consórcio sobre abastecimento e produção?

11 (ER) - Qual o custo para entrar no referido consórcio? Quais os benefícios que você pode prever no momento da entrada? Quais os riscos em entrar no consórcio?

12 (ER) - Você recebeu algum estímulo externo ao município para implantar o consórcio? E no município, houve algum estímulo?

13 (A) - Como foi escolhido o Secretário de Agricultura ou o responsável pelo consórcio em seu município? E o restante da equipe?

14 (A) - No momento da constituição do consórcio, quem eram suas referências pessoais? (cite 05 nomes que você lembra de imediato quando se trata da constituição do consórcio)

15 (A) - E depois da constituição do consórcio, quem eram as lideranças que conduziam o consórcio? No que consistia essa condução? 
16 (CS) - Depois da constituição do Consórcio, você consegue indicar a melhoria do setor agrícola no seu município? Por quê? Do ponto de vista de organização, houve algum tipo de iniciativa dos produtores? Dos trabalhadores rurais?

17 (CS) - Hoje, se acabar o consórcio há algum impacto em termos de reclamação de algum setor? Qual?

18 (G) - Tem algum comentário que você gostaria de fazer com relação ao consórcio e sua implementação? 
ANEXO 03

Relação de Entrevistas realizadas

Arieldes Macário Costa (61 anos), mais conhecido como Léo Costa, 61 anos, nascido em Barreirinhas, sociólogo, primeiro secretário executivo do CINPRA. Léo Costa é sociólogo, ex-funcionário da SUDENE (1966-70) e ex-prefeito Barreirinhas (1989-1992). É fundador estadual do PDT. Esta no PDT desde a primeira Comissão Provisória, formada por 11 membros, instituída em 1980.

(Entrevista relativa ao CINPRA)

Bernardo Ramos dos Santos (61 anos), Administrador de Empresas, foi candidato a prefeito do município de Humberto de Campos quatro vezes. Foi derrotado duas vezes (1988 e 1992) e vitorioso duas vezes também (1996 e 2000).

(Entrevista relativa ao CINPRA)

Borromeu, nasceu em Chapadinha, é geólogo. Foi funcionário público atuando em diversos órgãos. Trabalho 15 anos na Companhia Vale do Rio Doce. Em 1991, começou a atuar como autônomo. Em 1994, começou a trabalhar na Secretaria de Agricultura do Maranhão. Fez sua trajetória na área rural. Foi técnico do CINPRA (1997-2000). Em 2001, tornou-se Secretário de Agricultura do Município de Chapadinha. Atualmente é Diretor de Assistência Técnica do Estado do Maranhão.

(Entrevista relativa ao CINPRA)

Domingos (67 anos), administrador de empresas, Secretário Executivo do CINPRA- COCAIS com sede no Município de Timon, desde 2001, ano de sua fundação. Domingos foi Secretário de Agricultura de Timon, indicado por Chico 
Leitoa (2001-2004) e permanece no cargo até hoje, mesmo sob a liderança de uma prefeita que fez oposição a Chico Leitoa.

(Entrevista relativa ao CINPRA)

Jackson Lago (77 anos), médico, fez carreira política junto aos movimentos de redemocratização do país, participando do Movimento pela Anistia nos anos 70 . Em 1974, quando o então MDB e os movimentos de oposição ao Regime Militar, decidem a pedir voto e a não mais fazer campanha pelo voto nulo, Jackson Lago candidata-se e elege-se Deputado Estadual no Maranhão. Em 1979, viaja para Lisboa para ajudar Leonel Brizola a montar o que viria a ser o PDT. Organiza, no início dos anos 80, o PDT no Maranhão. Jackson Lago candidata-se a Prefeito de São Luís, em 1985 (não se elege); e a Deputado Federal, em 1986, quando foi o candidato mais votado do PDT e o quarto mais votado do Estado, mas como o PDT não atinge o coeficiente eleitoral, não se elegeu. Em 1988, volta a ser candidato a Prefeito em São Luís e, desta vez, elege-se. Em 1992, elege sua sucessora na Prefeitura. Em 1994, disputa pela primeira vez o Governo do Estado, e é derrotado por Roseana Sarney. Em 1996, volta a eleger-se prefeito de São Luís, e reelege-se em 2000. Em 05 de abril de 2002, deixa a Prefeitura de São Luís, para disputar pela segunda vez o Governo do Estado, e é derrotado por José Reinaldo (que naquele momento recebera apoio da família Sarney). O viceprefeito de Jackson Lago, Tadeu Palácio, termina o mandato (2002-2004) e reelege-se para o período 2005-2088. Em 2006, Jackson Lago disputa pela terceira vez o Governo do Estado e elege-se governador.

(Entrevista relativa ao CINPRA)

Jeroen Klink, economista pela Universidade de Tilburg (Holanda, 1987), doutor em Planejamento Urbano pela FAU-USP (2000). Foi Assessor Especial do Gabinete do Prefeito Celso Daniel, em 1997. Essa Assessoria Especial foi o embrião do viria a ser a Secretaria de Desenvolvimento e Ação Regional de Santo André, da qual Jeroen Klink foi secretário. Atualmente Jeroen Klink é professor- 
adjunto na área de Análise Econômica para Ciência e Tecnologia e Pró-Reitor de Extensão da Universidade Federal do ABC.

(Entrevista relativa ao Consórcio do Grande ABC)

José Mário Pinto Costa, engenheiro agrônomo e administrador de empresas, exsecretário de agricultura de Vitória do Mearim (1997-2000). Foi vereador por dois mandatos (1993-1996 e 1997-2000). Em 2000 foi candidato a prefeito derrotado. Em 2004, foi candidato a prefeito vitorioso. Atualmente é prefeito do município de Vitória do Mearim (2005-2008) e montou uma Agência de Desenvolvimento Regional em torno do município de Vitória do Mearim.

(Entrevista relativa ao CINPRA)

Francisco Rodrigues de Souza, mais conhecido como Chico Leitoa, engenheiro civil, deputado federal (2000). Disputou as eleições para prefeito em Timon em 1988 (derrotado), 1992 (vitorioso). Elegeu o sucessor em 1996. Em 2000 retorna à prefeitura como Prefeito. Em 1990 foi candidato a Deputado Estadual (derrotado) e em 1998 foi candidato a Deputado Federal (primeiro suplente). Acompanhou a criação e a evolução do CINPRA mesmo sem ser prefeito. Em 2001, cria, com estímulo de Léo Costa e Jackson Lago, o CINPRA-COCAIS. Atualmente é Diretor na Secretaria Estadual de Estradas e Rodagens do Estado do Maranhão e, por meio desta função, está desenvolvendo Consórcios Intermunicipais Rodoviários.

(Entrevista relativa ao CINPRA)

Júnior Lobo, filósofo, jornalista e escritor. Foi Secretário de Cultura de Léo Costa em Barreirinha (1989-1992). Entre 1997 e 2002, foi assessor técnico do CINPRA. Desde 2002, Júnior Lobo é Secretário Executivo do CINPRA.

(Entrevista relativa ao CINPRA) 
Marco Aurélio, foi Pesquisador de carreira da Empresa de Pesquisa Agropecuária do Estado do Maranhão. Em 1997, Marco Aurélio começou a participar do CINPRA como representante do governo do Estado. Em seguida, tornou-se assessor técnico do CINPRA. Em 2007, com a eleição de Jackson Lago a governador do Estado, Marco Aurélio tornou-se Superintendente da Agência Estadual de Pesquisa Agropecuária, Extensão Rural e Assistência Técnica do Maranhão.

(Entrevista relativa ao CINPRA)

Rafael Guerra, médico, pós-graduado pela Universidade de llinois (Chicago), em 1968. Professor e pesquisador da Faculdade de Ciências Médicas de Minas Gerais. Foi Diretor da Faculdade de Ciências Médicas de Minas Gerais (19871990 e 1991-1994). Em 1994 participou da campanha do candidato a governador Eduardo Azeredo (PSDB), de quem participou da elaboração do Programa de Governo. Foi Secretário Estadual de Saúde de Minas Gerais (1995-1998). Em 1998, elege-se Deputado Federal. Atualmente cumpre seu terceiro mandato (1999-2002, 2003-2006, 2007-2010).

(Entrevista relativa aos Consórcios Intermunicipais de Saúde - CIS - de Minas Gerais) 


\section{ANEXO 04 \\ Anteprojeto de Lei que autoriza o Poder Executivo a Participar do Consórcio Intermunicipal de Produção e Abastecimento de São Luís}

Autoriza o Poder Executivo a participar do Consórcio Intermunicipal de Produção e Abastecimento de São Luís e dá outras providências.

Faço saber que a Câmara Municipal aprovou e eu sanciono a seguinte Lei:

Artigo $1^{\circ}$ - Fica o Poder Executivo do Município de São Luís autorizado a participar do Consórcio Intermunicipal de Produção e Abastecimento de São Luís, sob a forma de Sociedade Civil, sem fins lucrativos, objetivando o planejamento e a execução de políticas comuns de Desenvolvimento Rural Sustentável, visando o abastecimento interno do município, o incremento das exportações, a fixação do homem ao campo e a distensão social das cidades.

Artigo $2^{\circ}$ - Fica o Prefeito do Município de São Luís autorizado a assinar Contrato de Constituição do referido Consórcio, dentro dos melhores interesses da população, do Município e da Região.

Artigo $3^{\circ}$ - Fica o Poder Executivo de São Luís autorizado a abrir Crédito Especial na importância de $\mathrm{R} \$ X X X$, para atender despesas iniciais decorrentes da execução da presente Lei, para o exercício de 2001, podendo ser suplementada se assim for necessário, devendo ser consignado nos orçamentos futuros o valor equivalente a 0,5\% (meio por cento) do Fundo de Participação dos Municípios (FPM).

Artigo $4^{\circ}$ - A presente Lei entrará em vigor na data de sua publicação, revogadas todas as disposições em contrário. 


\section{Observações:}

1. Para o exercício de 2002 , a participação mensal do município será calculada pela seguinte forma: tantas parcelas mensais que ainda faltam para completar o exercício financeiro baseada cada parcela no equivalente a $0,5 \%$ do PFM.

2. Para o exercício de 2003 e anos subseqüentes, como foi esclarecido na Lei, o valor de contribuição do município para com o CINPRA será de 0,5\% do FPM.

3. Para efeito do orçamento, deve-se estimar o FPM e converter a percentagem proposta em valores monetários reais. 


\section{ANEXO 05 \\ Mensagem enviada ao Presidente da Câmara Municipal solicitando autorização para participar do CINPRA}

Senhor Presidente da Câmara Municipal de São Luís,

Tenho a satisfação de encaminhar, à apreciação dessa Egrégia Câmara Municipal, Projeto de Lei solicitando autorização para que o Município de São Luís possa participar, juntamente com outros municípios da Região de São Luís, do Consórcio Intermunicipal de Produção e Abastecimento da Região de São Luís, visando o estabelecimento de esforços comuns de planejamento e ações que promovam o desenvolvimento sustentável do mundo rural, o auto-abastecimento alimentar da região, o incremento gradativo das exportações, a elevação da renda, o aumento dos empregos, a fixação do homem ao campo e a distensão social das cidades.

Como é do conhecimento de Vossa Excelência, o Sistema de Produção e Segurança Alimentar do nosso município apresenta uma série preocupante de carências e obstáculos em razão da escassez de recursos humanos, tecnológicos, organizacionais e financeiros que impedem o desenvolvimento pleno das comunidades rurais e dos agronegócios, com reflexos negativos sobre a nossa economia e a organização da própria cidade.

As políticas públicas até agora desenvolvidas não atendem às necessidades acumuladas do município, enfraquecendo nossa economia e a economia das famílias.

A opção mais desejada para edificar o Consórcio, na opinião unânime dos Prefeitos Participantes, é a criação de uma sociedade civil sem fins lucrativos que venha coordenar e articular os projetos e programas de desenvolvimento sustentável dos agronegócios da região. A principal vantagem é que nela poderão colaborar outras instituições governamentais e não governamentais, do país e do exterior, que se identificam com os objetivos marcros de redução dos níveis de pobreza e aumento da segurança alimentar. 
Os objetivos que se deseja alcançar e o desgaste a que se submeteram as formas tradicionais de atuação do poder público, aconselham seja instituída uma sociedade civil como forma de biabilizar as intenções do Consórcio.

O Projeto de Lei ora encaminhado contempla também a abertura de crédito especial para fazer face às despesas com as instalações do Consórcio, no presente exercício. Além do mais, destinar-se-á para a manutenção do Consórcio, o valor financeiro equivalente a $0,5 \%$ (meio por cento) da transferência mensal do Fundo de Participação dos Municípios (FPM). Como pode-se constatar, é uma despesa pequena em face dos benefícios que a ação conjunta haverá de trazer a todos.

O anteprojeto de Estatuto Social do Consórcio, anexado a esta Mensagem, complementa as informações necessárias à decisão de Vossa Excelência e de seus pares.

O Poder Executivo, como sempre, coloca-se à disposição dos ilustres vereadores para prestar outros esclarecimentos que forem julgados pertinentes.

Aproveito o ensejo para reiterar a Vossa Excelência protestos da mais alta consideração.

Assinatura do Prefeito do Município de São Luís. 
ANEXO 06

Estatuto do Consórcio Intermunicipal de Produção e Abastecimento - São Luís

CAPITULO I - DA CONSTITUIÇÃO, DENOMINAÇÃO, SEDE E DURAÇÃO

Artigo $1^{\circ}$ - O CONSÓRCIO INTER MUNICIPAL DE PRODUÇÃO E ABASTECIMENTO será constituído sob a forma de sociedade Civil de direito privado, sem fins lucrativos e reger-se-á pelas normas de legislação pertinente, pelo presente Estatuto e pelo regulamento que vier a ser adotado pelos seus associados, bem como pelas normas de princípios de direito privado aplicáveis.

Artigo $2^{\circ}$ - Considerar-se-á constituído o CONSÓRCIO INTERMUNICIPAL DE PRODUÇÃO E ABASTECIMENTO, uma vez subescrito este documento por um numero mínimo de 06 (seis) Municípios, devidamente representado por seus prefeitos, formalmente autorizado pelas respectivas Câmaras Municipais.

Artigo $3^{\circ}$ - CONSÓRCIO INTERMUNICIPAL DE PRODUÇÃO E ABASTECIMENTO terá sede e foro na cidade de São Luís.

Artigo $4^{\circ}$ - CONSÓRCIO INTERMUNICIPAL DE PRODUÇÃO E ABASTECIMENTO terá como área de atuação, os territórios dos Municípios que o integram, constituído desta forma uma unidade territorial, inexistindo limites intermunicipais, para atendimento das finalidades a que se propõe.

Artigo $5^{\circ}$ - CONSÓRCIO INTERMUNICIPAL DE PRODUÇÃO E ABASTECIMENTO terá duração indeterminada e ação social compreendida no período de $1^{\circ}$ de janeiro a 31 de dezembro de cada ano. 


\section{CAPITULO II - DA DEFINIÇÃO}

Artigo $6^{\circ}$ - CONSÓRCIO INTERMUNICIPAL DE PRODUÇÃO E ABASTECIMENTO define-se como articulador de políticas de produção e abastecimento que garantam o abastecimento local, viabilize a comercialização dos produtos excedentes para o abastecimento regional, nacional, internacional e priorize o modelo sustentável de agricultura de economia familiar

\section{CAPITULO III - DOS OBJETIVOS.}

Artigo $7^{\circ}$ - São objetivos do CONSÓRCIO INTERMUNICIPAL DE PRODUÇÃO E ABASTECIMENTO:

I - Representar o conjunto dos municípios que o integram, em assuntos de interesses comuns, perante quaisquer outras entidades especialmente às demais esferas constitucionais do governo;

II - Planejar, Adotar e Executar programas para garantir a melhoria da produção e do abastecimento, contribuindo desta forma, para geração de trabalho e renda mos municípios consorciados;

III - Implementar políticas que possibilitem a qualificação e o desenvolvimento de habilidades de produtores, suas famílias e técnicos.

PARÁGRAFO ÚNICO - Para o cumprimento dos seus objetivos. O CONSÓRCIO INTERMUNICIPAL DE PRODUÇÃO E ABASTECIMENTO, poderá:

a) Adquirir os bens que entender necessários, os quais integrarão o seu patrimônio;

b) Firmar convênios, contratos, acordos de quaisquer naturezas auxílios, contribuições e subvenções, contratos de outras entidades e órgãos do governo e setor privado; 
c) Prestar serviços aos seus associados, dentro de seus objetivos, fornecendo inclusive, recursos humanos. Materiais e financeiros.

\section{CAPITULO IV - DA ADMINISTRAÇÃO}

\section{Artigo $8^{\circ}$ - O CONSÓRCIO INTERMUNICIPAL DE PRODUÇÃO E} ABASTECIMENTO, terá a seguinte estrutura básica de Administração;

I - Conselho de prefeitos;

II - Conselho fiscal

III - Secretaria executiva.

Artigo $9^{\circ}$ - O Conselho de Prefeitos é o órgão deliberativo constituído pelos prefeitos dos municípios consorciados.

$\S 1^{\circ}-O$ conselho de prefeitos do CONSÓRCIO INTERMUNICIPAL DE PRODUÇÃO E ABASTECIMENTO, deverá ser presidido pelo prefeito de um dos municípios consorciados, eleito em votação secreta para o mandato de dois anos. Após a apreciação das contas do mandato anterior, permitindo - se a reeleição para mais um período sem remuneração.

$\S 2^{\circ}-$ Em caso de empate, proceder-se-á nova eleição. Persistindo a situação será escolhido o candidato mais idoso.

$\S 3^{\circ}$ - O vice-presidente será escolhido nos mesmos termos dos parágrafos acima citado, sem remuneração.

$\S 4^{\circ}$ - A suplência do conselho de prefeitos se'ra exercida pelos secretários de agricultura ou similares, sem qualquer remuneração. 
Artigo 10 - A secretaria executiva é o órgão executor das atividades desenvolvidas pelo CONSÓRCIO INTERMUNICIPAL DE PRODUÇÃO E ABASTECIMENTO.

\section{CAPITULO V - DAS COMPETÊNCIAS DO CONSELHO DE PREFEITOS}

Artigo 11 - Compete ao Conselho de Prefeitos:

I. Deliberar em última instancia, sobre os assuntos gerais do consórcio:

II. Estabelecer as políticas públicas comuns de produção e abastecimento do consórcio:

III. Referendar o secretario executivo do consórcio. Bem como determinar seu afastamento, substituição ou demissão;

IV. Estabelecer cotas de contribuição para cada município consorciado afim de viabilizar a operacionalização do consórcio;

V. Aprovar e modificar o regimento interno do consórcio. Bem como resolver e dispor sobre os casos omissos;

VI. Aprovar o plano de atividades e a proposta orçamental, elaborada pela secretaria executiva com forme as diretrizes do próprio conselho;

VII. Definir a política financeira, bem como os programas de investimento do consórcio;

VIII. Fixar a remuneração e o quadro de pessoal do consórcio;

IX. Viabilizar parcerias junto aos organismos nacionais, internacionais, instituições financeiras e agencia de desenvolvimento, para execução das ações estabelecidas pelo consórcio;

X. Aprecia no primeiro trimestre de cada ano, as contas do exercício anterior prestada pela secretaria executiva $z$ analisadas pelo conselho fiscal; 
XI. Prestar conta ao órgão publico concedente dos auxílios e das subversões que o Consórcio Intermunicipal de Produção e Abastecimento venha a receber;

XII. Deliberar sobre alteração do presente estatuto.

Artigo 12 - Compete ao presidente do conselho de prefeitos:

I. Presidir as reuniões e o voto de qualidade;

II. Empossar os membros do conselho fiscal;

III. Representar o consórcio, ativa e passivamente, judicial ou extra judicialmente podendo firmar contratos e convênios;

IV. Movimentar, em conjunto com o secretario executivo as contas bancarias e os recursos do consórcio, podendo esta competência ser delegada total ou parcialmente;

V. Indicar o secretário executivo do CONSÓRCIO INTERMUNICIPAL DE PRODUÇÃO E ABASTECIMENTO, que será referendado pelo conselho.

Artigo 13 - Compete ao Conselho Fiscal:

I. eleger seu presidente numa comissão relatora composta por 3 (três) membros suplentes, para apreciação prévia das contas do consócio;

II. Fiscalizar permanentemente a contabilidade do consórcio;

III. Emitir parecer sobre o plano de atividades, proposta orçamentária e relatórios de contas em geral, a serem submetidos ao conselho pelo secretário executivo;

IV. Verificar se as operações realizadas e os serviços prestados, correspondem em volume, quantidade, qualidade e valor, às previsões feitas e as conveniências econômicas e financeiras.

Artigo 14 - O conselho fiscal, através do seu presidente e por decisão dos seus integrantes poderá convocar o conselho de prefeitos, para as devidas 
providencias, quando forem verificada irregularmente na escritura contábil, nos atos de gestão financeira ou patrimonial ou ainda inobservância de normas legais, estatutárias ou regimentais.

Art. 15 - Compete ao secretário executivo:

I. Promover a execução das atividades do consórcio;

II. Elaborar o Plano de atividades e a proposta orçamentária anuais a serem submetidas ao Conselho de Prefeitos;

III. Admitir e dispensar pessoal fixando - Ihe limite das dotações orçamentárias e das diretrizes do consórcio;

IV. Elaborar o balanço e relatório de atividades anuais a serem submetidos ao conselho;

V. Elaborar os balancetes para a ciência do conselho de prefeitos;

VI. Movimentar, em conjunto como Presidente do conselho de prefeitos. Ou seu substituto legal as contas bancarias e os recursos do Consórcio ;

VII. Coordenar e supervisionar as Linhas de Ações estabelecidas pelo consórcio;

VIII. Submeter ao conselho a criação de comissões técnicas para desenvolver estudos e projetos e planejamento de trabalhos especiais;

IX. Viabilizar e operar o Centro de Informação Agrícola do Consórcio;

Parágrafo Único - As Comissões Técnicas serão o suporte da Secretaria Executiva, devendo ser criadas tantas quantas forem necessárias ao atendimento a suas atribuições e seus membros deverão ser designados pelo conselho de prefeitos.

\section{CAPÍTULO VI - DO PATRIMÔNIO}


Artigo 16 - O Patrimônio do O CONSÓRCIO INTERMUNICIPAL DE PRODUÇÃO E ABASTECIMENTO será constituído ;

I. pelos bens e direitos que vier adquirir a qualquer titulo;

II. pelos bens e direitos que forem doados por entidades publicas e particulares;

III. pelas contribuições e subvenções que vier receber.

$\S 1^{\circ}$ - nenhum bem poderá ser alienado. Sem expressa autorização do conselho de prefeitos.

$\S 2^{\circ}$ - a extinção do CONSÓRCIO INTERMUNICIPAL DE PRODUÇÃO E ABASTECIMENTO dar - se - á por delibera;cão da maioria dos seus sócios em pleno gozo dos direitos estatutários, em Assembléia Geral convocada especificamente para este fim.

\section{CAPÍTULO VII - DAS RECEITAS}

Artigo 17 - Serão considerada receitas do CONSÓRCIO INTERMUNICIPAL DE PRODUÇÃO E ABASTECIMENTO:

I. A cota de contribuição mensal dos municípios integrantes;

II. Auxílios, contribuições e subvenções concedidas por entidades;

III. Doações

IV. Juros bancários de operações de créditos;

V. Convênios com entidades publicas;

VI. Receita própria

VII. Outras 


\section{CAPÍTULO VIII - DAS REUNIÕES}

Artigo 18 - As reuniões do CONSÓRCIO INTERMUNICIPAL DE PRODUÇÃO E ABASTECIMENTO ocorrerão ordinariamente a cada bimestre ou extraordinariamente sempre que houver necessidade.

$\S 1^{\circ}$ - As reuniões ordinárias serão convocadas com antecedência de 08 (oito) dias, com local e hora preestabelecidos, devendo ser encaminha ás prefeituras Consorciados as agendas contendo Paula da matéria objeto da reunião.

$\S 2^{\circ}$ - As decisões nos casos de reunião ordinárias ou extraordinárias serão tomadas por maioria simples de voto.

$\S 3^{\circ}$ - O quorum para a reunião do conselho será, em primeira convocação, com metade mais um a segunda convocação, uma hora após com qualquer número.

\section{CAPÍTULO IX - DOS LIVROS}

Artigo 19 - As reuniões do CONSÓRCIO INTERMUNICIPAL DE PRODUÇÃO E ABASTECIMENTO serão anotadas nos seguintes livros:

I. livro de presença;

II. livro de ata de reuniões do Conselho dos Prefeitos;

III. livro de ata de reuniões do Conselho Fiscal.

\section{CAPÍTULO X - DAS DISPOSIÇÕES GERAIS E TRANSITÓRIA}

Artigo 20 - O presente estatuto somente poderá ser alterado pelo voto de no mínimo $2 / 3$ dos membros do conselho de prefeitos, em reunião extraordinária especialmente convocada para essa finalidade. 
Artigo 21 - A cota de contribuição mensal dos consorciados para o corrente exercício não poderá ser inferior a $0,5 \%$ do FPM e será suprida até o dia 05 do mês subseqüente.

Artigo 22 - Os prefeitos de cada municípios participantes do CONSÓRCIO INTERMUNICIPAL DE PRODUÇÃO E ABASTECIMENTO, responde solidariamente pelas obrigações assumidas durante seu período de atuação.

PARÁGRAFO ÚNICO: Os membros do Conselho do CONSÓRCIO INTERMUNICIPAL DE PRODUÇÃO E ABASTECIMENTO, não responderão pessoalmente pelas obrigações contrarias em nome do CONSÓRCIO INTERMUNICIPAL DE PRODUÇÃO E ABASTECIMENTO. Contudo, assumirão as responsabilidades pelos atos praticados de forma contraria à Lei ou ás disposições contidas no presente Estatuto.

Artigo 23 - Fica autorizado o Conselho de Prefeitos a obter o registro do presente instrumento, no Cartório de Registro Civil de Pessoas Jurídicas na cidade de sua sede para que adquira personalidade Jurídica de uma Associação Civil, após a devida publicação no Diário Oficial do Estado do Maranhão.

Artigo 24 - Todos os casos omissos neste Estatuto deverão ser decididos em reunião do Conselho de Prefeito, devendo ser a votação decidida por maioria simples de voto.

São Luís (MA), 13 de Outubro de 1997 
ANEXO 07

Estrutura Organizacional do CINPRA

(Semelhante a vários outros Consórcios Intermunicipais)

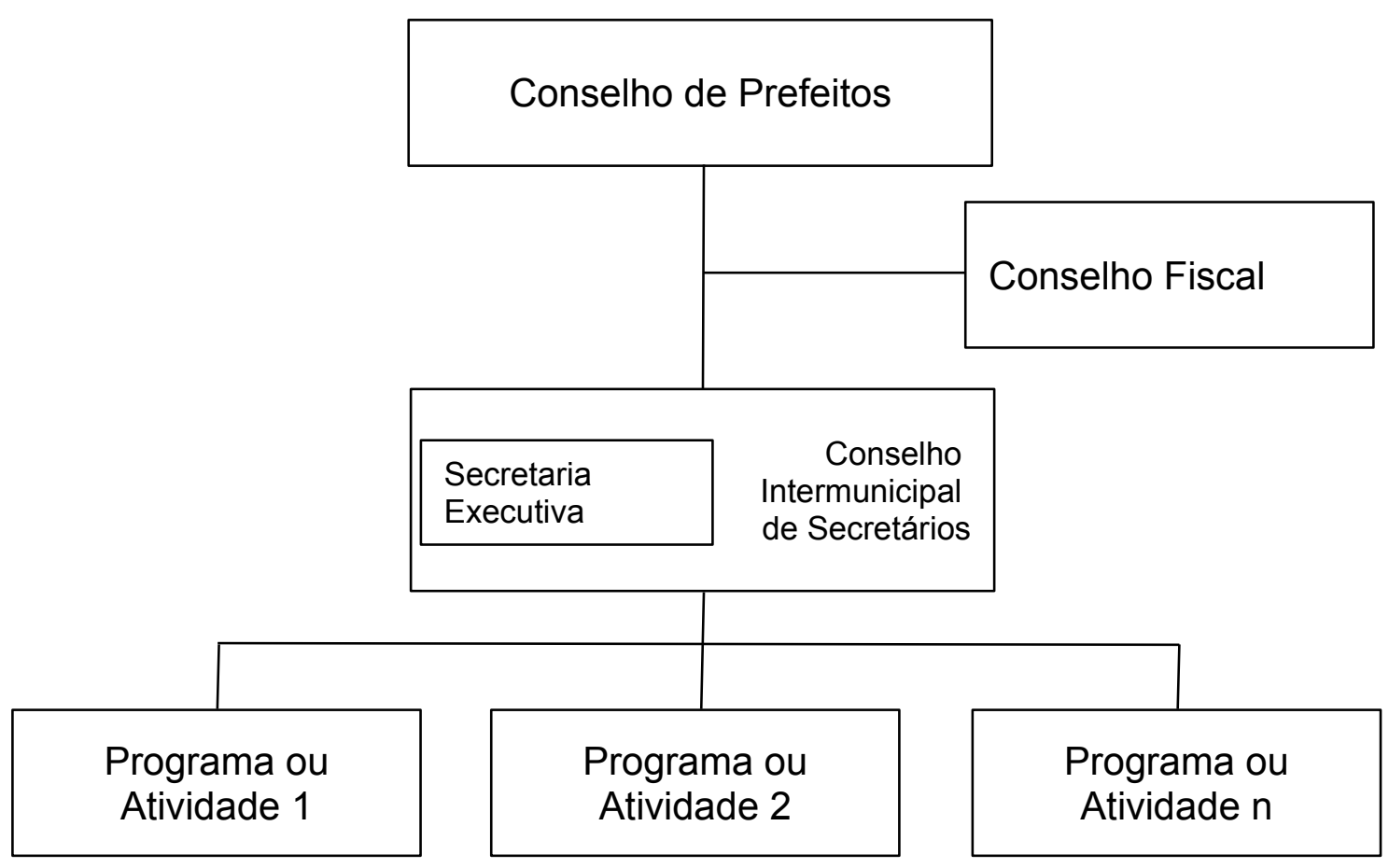

Fonte: Cruz (2002) 
ANEXO 08

Guia para Criação de Consórcios Intermunicipais de Produção e Abastecimento

\section{Vontade Política}

Para criação do Consórcio regional de produção e abastecimento é preciso vontade política de cada prefeito. Uma decisão política de que ele quer desenvolver a agricultura, com a consciência que esse setor é prioritário para geração de mais trabalho e renda no seu município.

\section{Articulação com outros Municípios da Região}

Procurar outros municípios da região que pensem da mesma forma e combinar com seus dirigentes a criação de um consórcio de produção e abastecimento para, juntos, discutirem e encontrarem os caminhos do desenvolvimento da agricultura local e regional.

\section{Autorização da Câmara}

Para participar do Consórcio de Produção o prefeito deve enviar uma Mensagem de Lei à Câmara Municipal solicitando autorização para que o Município integre aquele consórcio combinando com os representantes das outras prefeituras da região - ação esta que todos os municípios devem fazer simultaneamente. Aprovado pelo Poder Legislativo, o Poder Executivo sanciona a Lei, e a encaminha para os organizadores do Consórcio.

\section{Criação do Consórcio}

De posse da Lei que Ihes autoriza a participar do Consórcio, os prefeitos devem reunir-se constantemente para elaboração e aprovação do Estatuto e, em seguida, oficializar a fundação da entidade. 


\section{Fundo Comum}

Dentro da Lei, há uma autorização da Câmara Municipal destinando um percentual do Fundo de Participação dos Municípios (FPM) para o Consórcio Intermunicipal - valor este que deve ser discutido e acordado entre os prefeitos da região. Esse fundo comum serve para instalar e manter a Secretaria Executiva que é o braço executivo do Conselho de Prefeitos e que vai tocar as ações do Consórcio de Produção. No caso do CINPRA, cada município-membro contribui com $0,5 \%$ do FPM.

\section{Fortalecimento do Sistema Municipal de Produção}

Não importa que o nome seja Secretaria Municipal de Agricultura - seria bom que fosse assim em todos os municípios. Pode ser uma Secretaria do Trabalho ou de Desenvolvimento. O importante é que tenha uma equipe local de bons agrônomos, técnicos agrícolas e veterinários - de acordo com o poder financeiro, a prioridade de cada município e a paixão de cada prefeito pela agricultura. Sem este órgão local para tocar o processo de desenvolvimento da agricultura não tem sentido o município fazer parte do Consórcio. A municipalização da agricultura começa pela organização de uma boa equipe local e fortalecimento do órgão responsável pelo sistema municipal de agricultura.

\section{Buscar Parcerias}

A primeira parceria que o Consórcio de Produção tem que buscar é interno - é preciso que toda a sociedade seja parceira dessa luta. Devem ser parceiros, também, o Governo do Estado, as instituições financeiras - principalmente as de fomento agrícola (Banco do Nordeste, Banco do Brasil, Caixa Econômica Federal e Banco da Amazônia), as instituições nacionais voltadas para a produção (ministérios, BNDES, os centros de pesquisas - como os da Embrapa, as universidades, dentre outros). 


\section{Valorização da Cultura do Mundo Rural}

O Consórcio é todo um movimento voltado para a valorização da cultura do mundo rural. Um mundo que é muito rico culturalmente, com suas tradições, suas crenças, seu folclore, sua história, sua literatura, sua música, sua gastronomia. E como em todas as partes do mundo o ser humano está se voltando par o meio ambiente, a zona rural volta a ter significado todo especial. É nesse momento que as comunidades rurais devem ser ajudadas para tirar o máximo de proveito para gerar mais emprego, mais renda e mais qualidade de vida.

\section{Visão de Agronegócio}

A visão original de um Consórcio dessa natureza é a visão do agronegócio, pois trata-se de um Consórcio de produção, de transformação e processamento, de marketing, de abastecimento e de comercialização. É ter produto de qualidade agregar valor a esse produto, sempre tendo em vista a pesquisa de mercado. É saber o que produzir, com que recursos, tecnologia, em que quantidade, vender para quem (que mercado atingir), em que embalagem, a que preço, etc. Essa visão de agronegócio serve tanto para os produtos agrícolas, como para os produtos pecuários, serviços rurais como um todo. A diversificação de produtos e serviços de qualidade resultarão em mais empregos e maior enriquecimento do meio rural, do município como um todo e da própria região. 